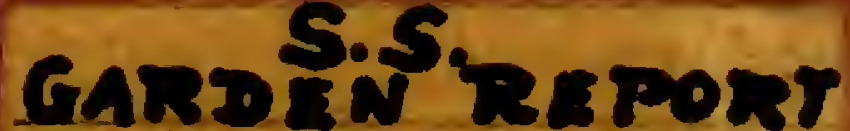 1920-1934
}




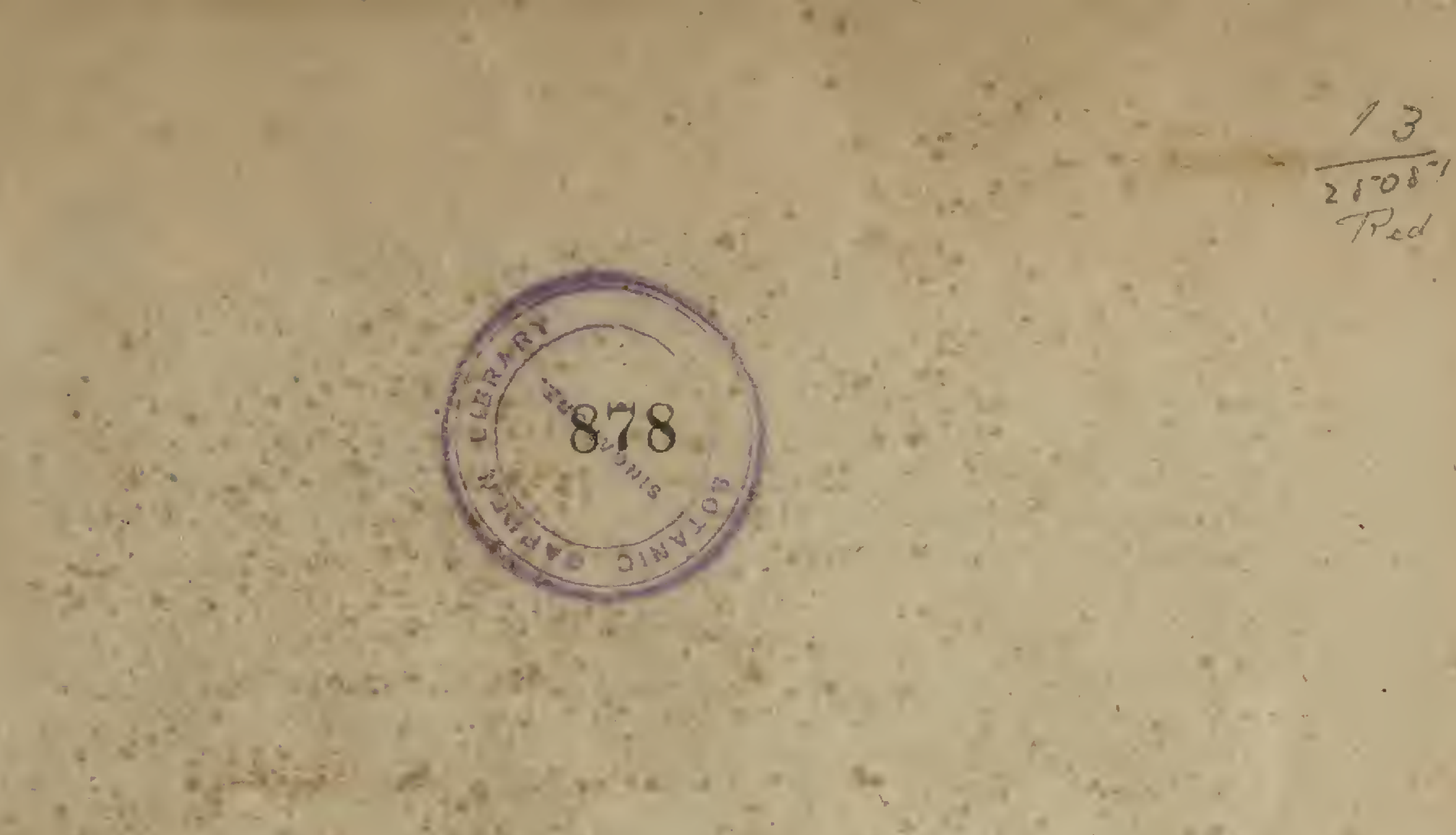

Annual Report of the-Director of Gardens for the Year 1920.

During 1920 the following were so good as to give their services upon the Committees of Management:-

Gardens' Committee, Singapore.-Messrs. D. Beatry (from June 8th), and P. Cunliffe (from February 8th), the Hon'ble Mr. H. W. Firmstone (to February 27th), Messrs. W. G. Hennings (from November 9th), E. S. Hose (to Octoher rst), I. G. Hubiack and W. P. Ker (to May I8th), the Hon'ble Dr. Lim Boon Keng, the Hon'ble Mr. W. Lowther Kemp, the Hon'ble Mr. F. J. PIgotT, and Mr. E. C. H. WolfF (to May 2oth). Committee of Management for the Waterfall Gardens, Penang: the Hon'ble the Resident Councillor-(Mr. G. A. Hall, to February 27th, and Mr. H. W. Frrmstone afterwards), Mr. Lawrie C. Brown, Mr. J. D. Fettes, Captain H. M: S. Haughton (from May I4th), Dr. P. Liston (from June $\mathrm{I} 7 \mathrm{th}$ ), and $\mathrm{Mr}$. HÁstings RHODES (from July $\mathrm{r} 6 \mathrm{th}$ ). The Committec of Management for the Government House Domain consisted of the Director of Gardens with the Aide-de-Camp to His Excellency the Governor.

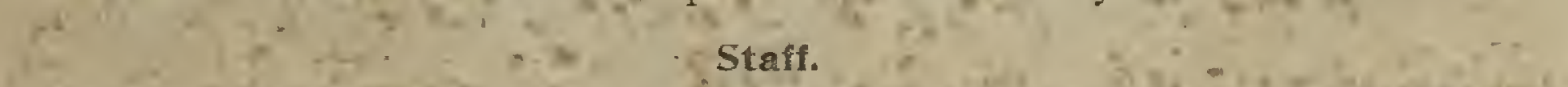

The Director was on leave until June 13th. Up to that date Najor T. F. Chipp, Assistant Director, acted as Director. On December r 4 th Major Chipp proceeded on leave, prior to transfer to West Africa. Except for a short period of deputation to lay out the Gardens at Bel Retiro, Penang Hili, Mr. Futppance was at his post of Assistant Curator, Botanic Gardens, Singapore, throughout the year ; and Mr. MoHAMED HAxtFF, except for a short period of illness, was in executive charge of the Waterfall Gardens, Penang. Mr. E. H. MathIEU remained in the service of the Department until July 3Ist, having executive charge of the Economic Garden. Mr. G. B. DeshmukH worked under him until then, and afterwatds took oyer his charge. Mr. Kastañ Bin JALIL, Foreman Grarcletier in the Botanic Gardens, died on July 7 th - a great loss to the Department in which he had served 33 years.

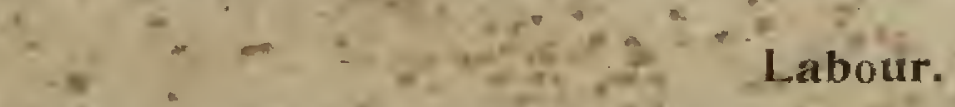

Labour, uneasy at rising prices; was difficult to retain, and after the first quarter of the year, the forces were never at proper strength. In March, in Singappore, all the youngêr Jayanese mostly mowers-were induced to leave for a rubber estate; but the older Javanese in' service, who are married and suitably housed in a compact colony of their own, stuck by the Department: the Tamils changed considerably. In Penang almost all the trained men were lost over the early months of the year; and great difficulies were experienced in maintaining the amenities of the Gardens after that misfortune. There is wisdom in domiciling a force of married men. Twice in Singapore, and twice in Penang; wages were increased; but the Department had lost men and it was impossible " the general scarcity of labour to rebuild the forces satisfactorily. By th sanctioned increments the coolie's wage stands at 70 cents per diem in $\subseteq$ yapore, and at 62 cents in Penang. The increases amount to 75 and $93 \mathrm{pr}$ : cent on the wage of 1916 , or to 20 and 60 per cent on that of I9I9. Since 5 re ble watchmen have been hard to get. at a wagie increased by 56 per c. 
It was found necessary to supply rice on credit to daily labour in Singapore: and the same course would have been useful in Penang, but difficulties stood in the way of adopting it.

\section{Expenditure and Revenue.}

With the labour force so much under due strength there was in Singapore a saving upon the votes for labour which covered, with a considerable margin, the rise in daily wages; but an extension had to be taken to mee: the greater rise' in Penang, and also the rise on the Government House Domain. Small extensions had to be taken also for travelling expenses, and for other expenditure in Singapore and in Penang. Revenue in Singapore came in well, attaining $\$ 9,316.8 \mathrm{I}$, made 11 of $\$ 6$, IOI.29 from rubber, and $\$ 3,215.5^{2}$ from the sale of plants. It fell, however, in Penang where it was $\$ 975.72$. The demands of the public showed no sign of decrease during the year; but the loss of labour in Penang diminished the supplying power there.

To replenish the stock of tools, etc., which had of necessity been kept at the lowest possible margin during the war, a larger expenditure than usual was necessary. Expenditure on timber and manure was also great. The local prices of timber might be regarded as exorbitant, and the price of manure as excessive; but there was so much competition for the available supplies of these that the sellers could sell as they pleased. Compensating economies were effected in material of other kinds.

It is becoming a permanent condition that cattle manure is difficult to get in anything like adequate quantities; and therefore artificial manures have been ordered. The price of cattle manure at the same time is high; so that the amount required by the Gardens now costs five times as much as it did ten years agoi. Opium refuse, which was thrown into the sea formerly, is being used in the Gardens experimentally as a manure. It decomposes very slowly; - this in part because it has been thought necesodry to vury it deeply; but it is puosiblo thal by mixing it with rew dung, and so innoculating it with bacteria, sufficiently rapid decomposition will be set up.

\section{Building}

In Singapore a new brilding holding the Director's office, libratry and laboratory was erected, but not completed. The servants' quarters at the Director's and Assistant Director's houses were improved. Lines for ten married Javanese were built. The water-pipe system to the Javanese lines and subordinate quarters was relaid by the Municipality from the Cluny Road main instead of from the remoter Dalvey Road main, thus liberating piping enough for the water supply to the new laboratory. In Penang the lines were repainted.

\section{Investigations and collections.}

Living collections.-The Department gratefully acknowledges the receipt of plants and seeds from Mrs. M. BARRY, Mrs. A. W. D. DOVE, Mrs. Knollema, Messrs. C. Boden-Kloss, H. M. Bone, G. Farmer (Elaeis), H. L. Jeppesen, C. V. Piper, E. L. Villiters (Cannas), C. L. Wragge, Dr. F. W. Foxworthy, Dr. J. D. Grmlette, Professor I. F. Rock, Dr. J. J. Sмrтh, the Royal Botanic Gardens, Kew and Calcutta, the Botanic Gardens, Bangalore, Brisbane, Buitenzdrg, Georgetown-Demerara, Hongkong and Port Darwin, the Colonial Gardens of Laecken, the State Nursery, Gwalior, the Agricultural Departments of the Federated Malay States, Burma, Sierra Leone and Mauritius, the Bureau of Agriculture, Philippine Islands, the Department of Agriculture, United States, the Director of Museums, Federated Malay States, the Agri-Horticultural Society of India, and the Conservators of Forests, Perak and Nigeria.

The Director visited Calcutta and Kew when on leave; and the results of requests made there have come in: from the Royal Botanic Gardens, Calcutta, the Department received 57 plants, together with a consignment 
of twenty plants of the celebrated Nagpur Orange; from the Agri-Horticultural Society of India, which has its head quarters in Calcutta, were received I30 races of Canna, some races of Hedychium and various other plants; from kew 55 plants were received, both ornamental and economic.

The numbers of entries in the Department's "Plants inwards" books were:-

in Singapore I,254, referring to 621 plants and I,067 packets of seed;

in Penang 108, referring to 523 plants and 92 packets of seed.

Seed of twenty-seven palms new to the collection has been obtained. Attalea Colnune, the palm used by the rubber collectors on the Amazon for smoking "hard para," began to fruit in the Gardens, where it has been for about twenty-five years. A few years ago a local newspaper advocated the growing of this palm for the oil in its seed, without first ascertaining in any way the age at which it fruits. Experience does not justify advocating it.

Believing greatly in the value of the Avocado pear for Malaya, the Department has got plants of five races now, and hopes to get more.

The Director of Agriculture, Sierra Leone, upon request, sent tubers of the yam found by him to be a heavy yielder in West Africa and called in his reports the "Hausa potato". It proved to be the Lesser Yam of the East Indies (Dioscorea esculcuta).

The Director of Agriculture, Philippine Islands, upon request, supplied suckers of the five best races of pisang (banana) grown in his experiment stations.

As the Department of Agriculture; Ceylon, had advertised the stock of young plants held for the purpose of supplying the public, for the sake of comparison a count of corresponding stock in the Colony was taken at the end of the year; and the numbers were found roughly equal, there being 37,400 plants in Singapore, and II, IOO in Penang.

Dry collections.-Herbarium specimens were gratefully received from the Forest Department $\left(\mathrm{t}, 05^{2}\right)$, the Bureau of Science, Manila (882), the Botanic Gardens, Buitenzorg (444), His Highness the Prince Bonaparte (I34), Professor C. F. BAKER (100, being his sixth century of Malayan Fungi), Mr. A. R. Sanderson (26), Dr. Lim Boon Keng, Messrs. C. Boden-Kloss, J. C. Moulton, G. E. Perry, and F."W. South.

The Assistant Director, Major CHIPP, collected fungi through Singapore island and to a small extent elsewhere; the Director after his return collected the higher plants in a few places, c.g., Penang, Ipoh, Kuala Lumpur, Gemas. Mr. Mohamed Haniff collected, upon a visit for seeds, in the neighbourhood of Sungei Siput, Perak; and Major Moulton collected for the Department upon the Upper Baram river in Sarawak about Lio-matu and on the mountains to the north of it. Dr. Docters van Leeuwen, Director of the Botanic Gardens, Buitenzorg, visited the Settlements, and collected galls which particularly interest him; and this splendid opportunity was taken by the Department of submitting to him a further collection of galls.

Major CHIPp's "List of the Fungi of the Malay Peninsula" (Gardens" Bulletin, II. pp. 3II-4I8) is a very important publication from the Herbarium.

The following herbarium specimens were sent out:-

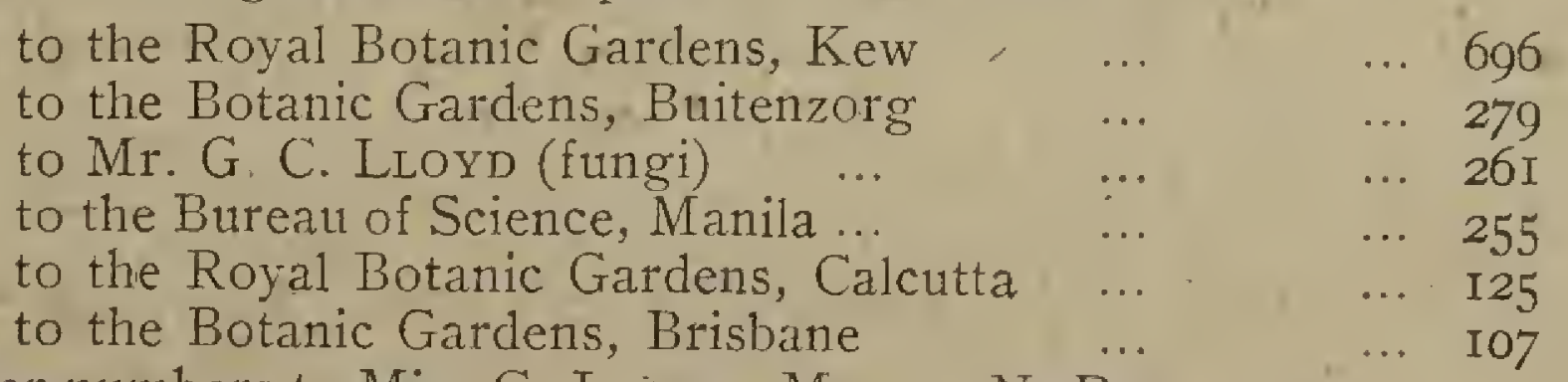

and lesser numbers to Miss G. Liśter, Messrs. N. Patouillard,

E. Cheel, W. Hales, J. R. Weir, H. N. Dixon, J. Groves,

M. Persin, and the Department of Agriculture, Pretoria … 220

Total .. $\overline{r, 943}$ 
All the herbarium specimens of the order Urticaceae were loaned to the Superintendent of the Royal Botanic Gardens, Calcutta, for working up in the Materials for a Flora of the Malay Peninsula. The specimens of the genus Canavalia were loaned to Kew.

Mounting paper being still at a very high price, mounting was in general deferred, but cannot be deferred longer as the accumulation of unmounted material is becoming unworkable.

For the gift of books the Department is endebted to His Highness the Prince Bonaparte (his Notes Ptéridologiques, fasc. VIII), Professor Oakes Ames (his Studies in the family Orchidaceae, Vol. VI), Dr. A. O. Farwell (several tracts on pharmacology, etc.), the Trustees of the British Museum (Mr. FawCetT's and Dr. Rendle's Flora of Jamaica, Vol. IV), the Forest Department (valuable manuscript on Malayan economic plants), the Editor of the Gardens' Bulletin (his numerous exchanges), and generous departments such as the Agricultural Department of the United States, the Botanic Gardens, Buitenzorg, etc.

\section{Botanic Gardens, Singapore.}

Every resident knows how motor traffic has increased in Singapore; and the wear and tear 11pon the Gardens' roads has greatly increased with it. In the report of IgI 2 it was remarked that a few cars then entered the Gardens at night; but now, band-nights excluded, from a count the average number is found to be 24 with a maximum of 107 . On a band-night there may be nearly five hundred cars parked on and near the Band-stand, until there is no room for more. No count of the numbers of cars which travel over the Gardens' roads by day has been possible.

The Liane road was re-metalled; but not the other roads which were down for repair. There was difficulty in procuring laterite.

The Wormias were cut back at the head of the lake. Further planting was done in the Area $Z$.

Of changes altering the appearance of the Gardens there were none in I920, except that one of the beautiful trees of Casuarina sumatrana, near the main gate, died; and an Agathis by the old office and four other trees were blown down on July 8th. The old tree of Canarium conmune, which is older than the Gardens and stands near the Plant House, began to exhibit signs of disease. The patch of the Gardens' Jungle attacked by Rosellinia echinata showed signs of recovery in the centre; but the fungus is still on the periphery. A ditch was dug and heavily limed to check its spread southwards; and liming resorted to on the margins generally. The recovery is marked by a big and very vigorous growth of the fern Neplerolepis acuta. An unusual dry spell at the close of November produced a wealth of colour, making many plants flower in profusion.

By the kindness of Lieutenant-Colonel L. B. Boxd-Moss, C.M.G., D.s.o., and of the officers, the band of the Ist Battalion, South Staffordshire Regiment, played in the Gardens twice monthly, and the Regimental Drums beat "retreat". in the afternoon of one day in each alternate week.

The demand for plants was greater than it has ever been; and the number sent out was 14,253 , together with 262 packets of seed. Two wardian cases were sent to Kew under the charge of the Assistant Director, containing, with ornamental plants, certain Malayan fruit trees asked for by His Excellency the Governor of Sierra Leone.

Labour was used in the following ways:-for pot-plants, at the rate of 8.90 men per diem; for cleaning roads and paths, II.46: for lawns, 9.15; for bedding 5.17; for nurseries 3.53; for sweeping 4.51; for caring for the trees 2.56 ; for rockeries, 0.09 ; for cleaning the lakes, 0.69 ; and miscellaneous I 83 .

Much of the aggressive grass, Paspalum platycaule, was removed from the lawns; but it comes back if the smallest scrap is left, just as the allied $P$. dilatatum does in the Botanic Gardens, Sydney, whence it is reported as the worst local pest. 


\section{Economic Garden.}

Through the first part of the year, the food-crop demonstration by the Riding track, which was described in the last report, demanded a considerable amount of Mr. MATHIEU's attention; but gradually its agricultural crops were abandoned for horticultural crops. As the cropping changed the area was marked out into plots each of I/Io of an acre; and the same was done upon the hill-top: this gives a far more business-like arrangement than existed before. The plots on the hill-top were kept in food crops interplanted with fruit trees, because the cultivation for the food-crops was of benefit to the young fruit trees.

The right to tap the rubber trees was let for the first half-year for $\$ 800$ per mensem; but the tappers who were paid by the lessee on results grew very apt to over-tap. The same was the case with the tappers of the lessee who followed for one month only; and after that the amount offered for the rights was not worth accepting against the trouble of seeing that the tappers did not damage the trees. In Igro a fibre-yielding race "altissima" of the Rozelle had been brought into the Gardens where it grew well. Fibre in I920 was made from it by Mr. Mathieu in the way that jute is prepared; and was pronounced at the Imperial Institute, London, equal to the first marks of jute. It is desirable now to know if a yield so much greater than that of jute can be got as will enable it to be produced by labour far more expensive than the labour which produces jute. The isolated 23-year old Brazil nut tree continues to flower yearly but has not produced fruit yet, as the pair of 3o-year old trees have been doing for a tiumber of years. "Is it a consequence of isolation? The 20-year old Caryocar trees have produced imperfect fruits for a second time. It is hoped that they will soon produce fertile seeds. Srartzia pinnata flowered and fruted.

Of economic plants 665 were sent ont and I62 packets of seed. These included nearly 6,000 seeds of the African Oil Palm.

Labour.-Over the first five months of the year upon an average 65 men, women or boys were employed daily in the Economic Garden. The record of the distribution of labour for those months is missing. Over the remaining seven months, when the average number of men could not be raised-above 35, labour was put to different kinds of work as follows:digging, weeding and planting 12.87 per diem; for keeping the grass slopes tidy 8.I9: on plants in pots, 2.03; on tree-cutting and pruning 0.86 ; on sweeping 3.50 ; on roads $2.6 \mathrm{I}$; on ditching $\mathrm{I} .02$; in burying opium-refuse, I.99; on miscellaneous work, I.40.

The deep burying of the opium-refuse is costing too much, and other methods of using it are being tested.

\section{Waterfall Gardens, Penang.}

As in Singapore, so in Penang there has been a great increase in the amount of motor traffic in the Gardens. This entails an increase of labour upon the roads; and taking the year as a whole two additional men have been required in the Waterfall Gardens for that service. It has been decided to attempt an economy by asphalting the lower roads. To make traffic safer, the gate has been widened to almost 40 feet.

A weir was built upon the stream just above the Central Bridge to control the current; and another weir is planned to hold up still water under the bridge.

The metal work of the plant houses was repainted by the Gardens' labour, and re-roofing done. At the same time tiles were laid upon the southern bench of house No. 9 .

To increase the colour in the Gardens, beds were made round the trees lining the Lower South Road and in the hollow of the upper part of the Gardens; but wild pigs damaged the latter. To keep the shrubberies tidier, three rubbish pits were made upon the outskirts of the Gardens and all other dumps of leaves destroyed. The regetation in the Swimming Bath gully 
was thinned; and an old footpath reopened from it to the site of the abandoned Gardens' bungalow whence there is a good view. It is a practice to plant palms that have become too large to retain in the plant-houses and other woody plants as available near this footpath. The Swimming Bath gully is an ideal Aroid garden.

The n. … Latania Commersonii and Attalea Cohune, flowered but did not fruit, ... Latania: were given to the Gardens in IgI I by Mr.. LOGAN and were a few years old then. Dichopsis Gutta, the gutta taban, fruited at the age of 2I years. Among orchids a Spathoglottis, got by Mr. HanifF on Kedah Peak, proved on flowering to be $S$. affinis which is new to the Peninsula. A curious and probably. new Habenaria from Champawn also flowered. Hydrangeas which had long remained flowerless in Singapore after having been sent to Penang flowered, but not conspicuously.

During the year 2,270 plants were sent out, and 426 packets of seed.

Labour was utilised as follows:-for pot-plants at the rate of 9.24 men per diem; on lawns 6.69; on trees 2.25; on sweeping 1.92 ; on bedding 2.75 ; on roads 8.37 ; on nurseries 2.05 ; on rockeries 0.33 ; on lakes and on drainage work 0.64 ; on the repair of the plant houses including repainting 0.94 ; on work upon the stream hank 0.50 ; and miscellaneous $0.3 \mathrm{I}$.

\section{Government House Domain.}

Labour upon the Government House Domain was thus distributed:on the lawns at the rate of 13.33 men per diem; on bedding 7.99 ; in nurseries 3.99; on pot-plants 3.29; in house-decoration 0.85 ; for hedging and treecutting $2.8 \mathrm{I}$; for sweeping and cleaning 4.08 ; for-shrubberies I.92; at the Colonial Secretary's house for all manner of work 4.25; and at the Private Secretary's house r.86.

\section{(72*- - th Miscellanenus.}

The Sub-Inspector of Agriculture, under an arrangement with the Director of Agriculture, continues to report weekly at the Gardens.

The acting Director visited Penang and Kuala Lipis to advise in connection with the laying out of the grounds of the Crag Hotel and of the thenproposed Residency at Kuala Lipis.

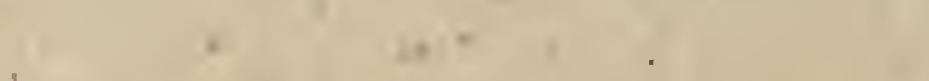

Botanic Gardens,

SingAPORE, 6th May, Ig21. $\quad[$ No. $4606 / 2$ I. $]$
I. HENRY BURKILL,

Director of Gardens, S. S. 


\title{
STRAITS SETTLEMENTS.
}

\section{ANNUAL REPORT}

\author{
OF THE
}

\section{DIRECTOR OF GARDENS,}

\section{STRAITS SETTLEMENTS,}

\author{
FOR THE YEAR
}

\section{1}

BY

I. HENRY BURKILL, M. A..

Jirector of Gardens, Siraits Settlencents.

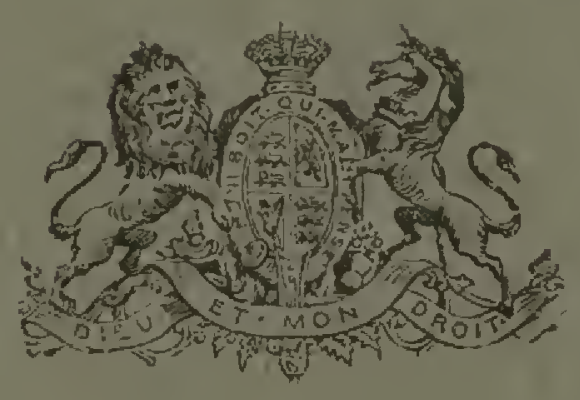

PUBI.ISHED BY AUTHORITY.

\section{Silla apote:}




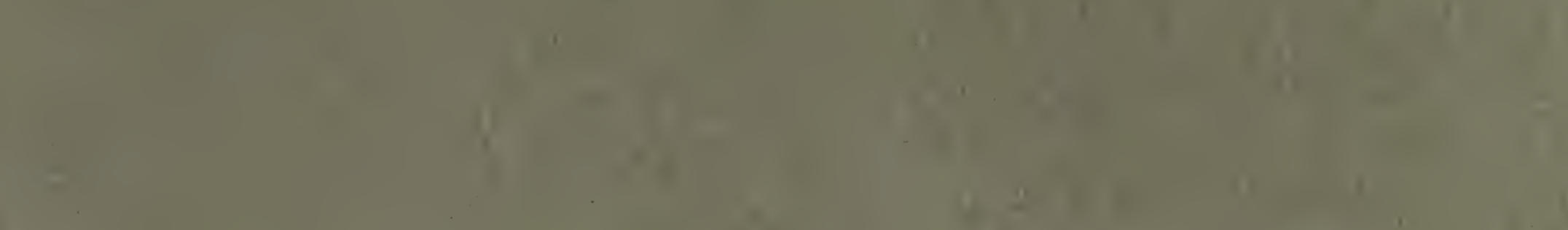

8. a.

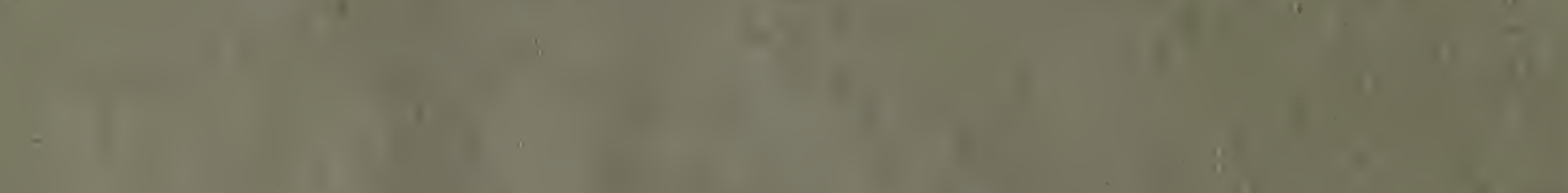

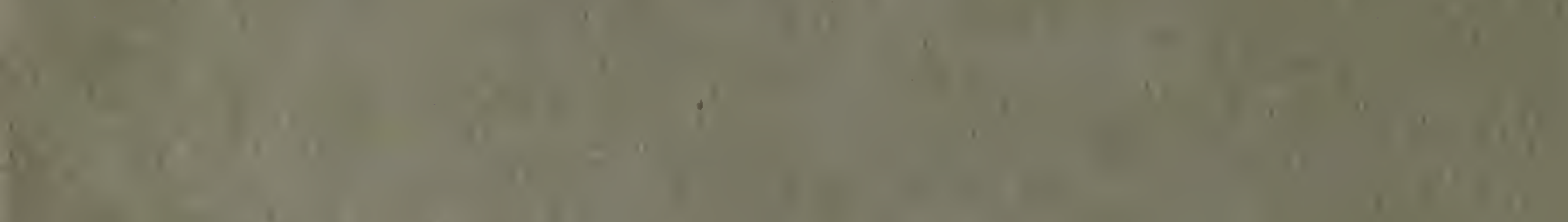

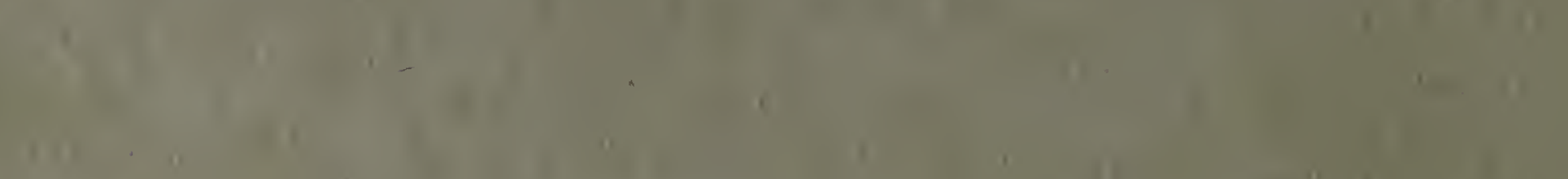

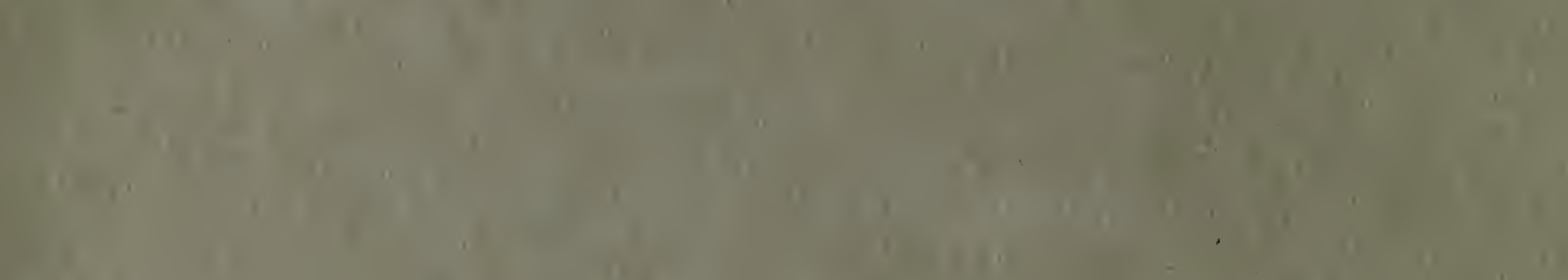

s.t.

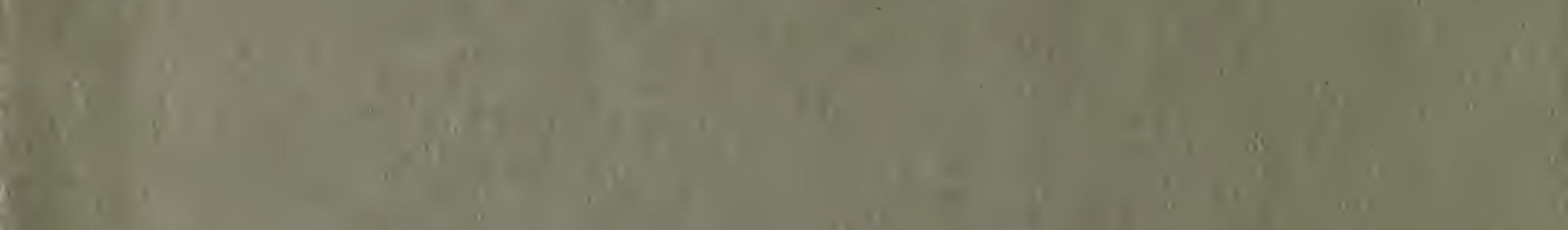
W.

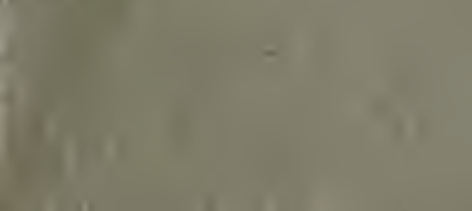

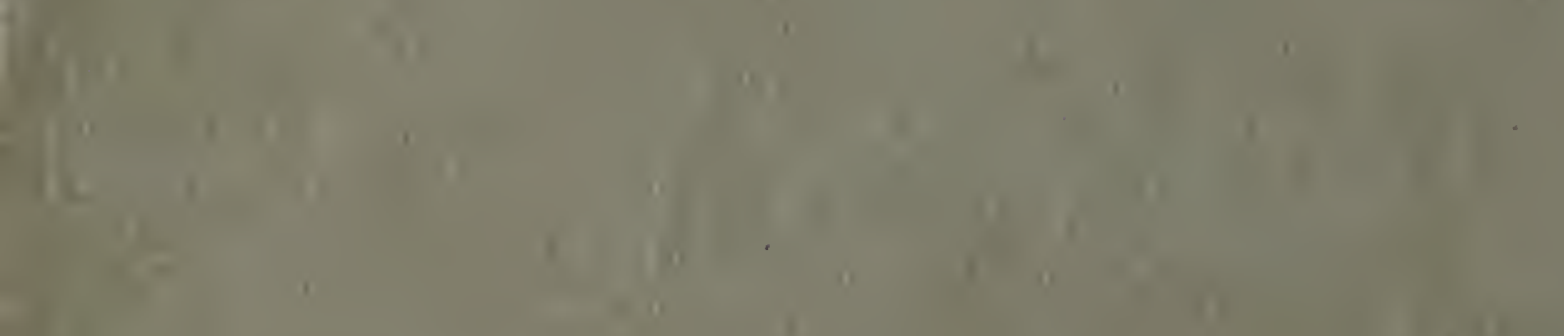

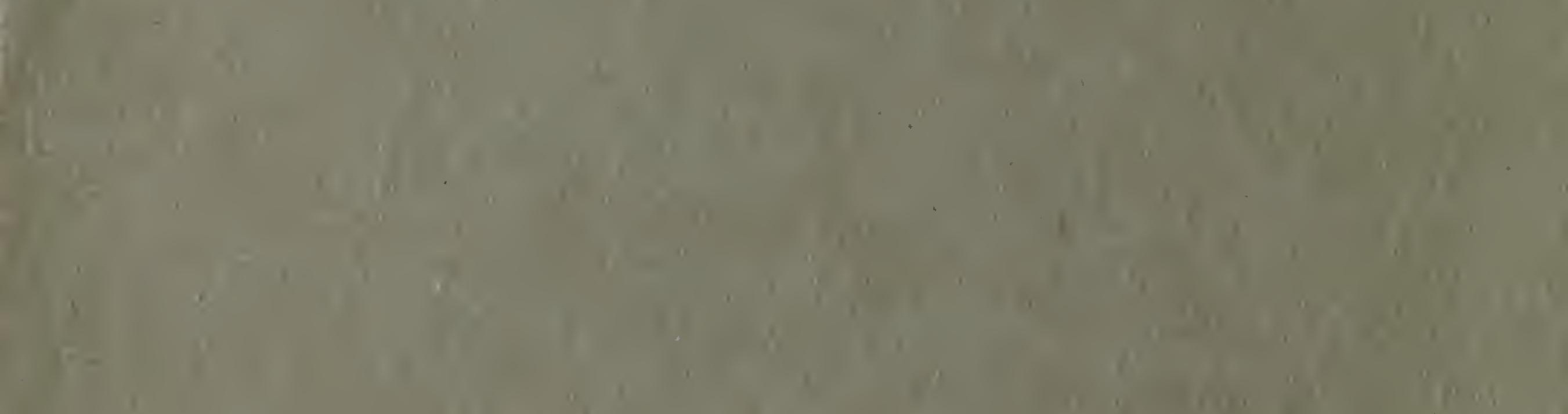

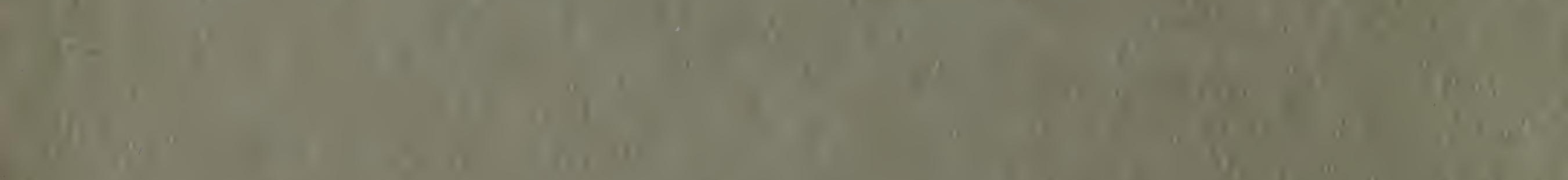

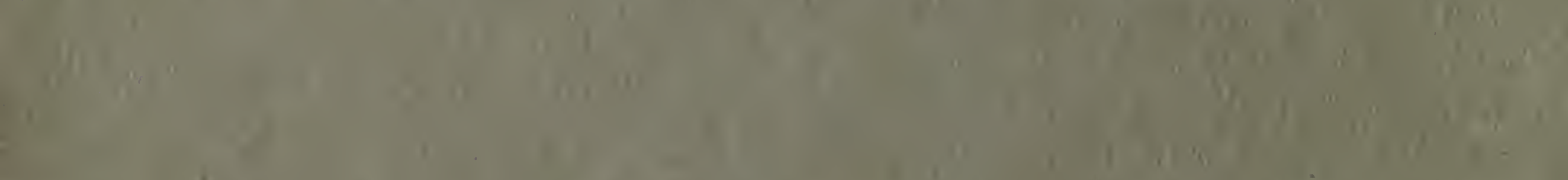

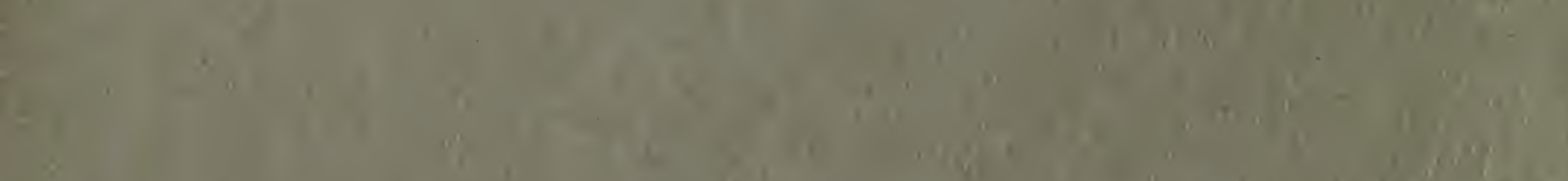
(1)

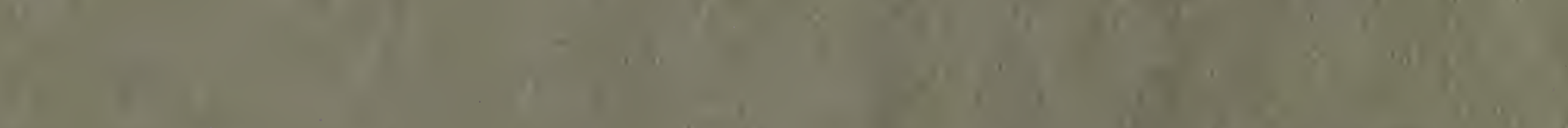

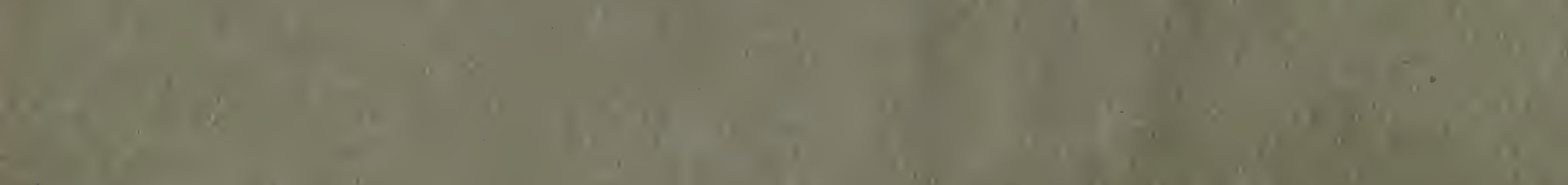

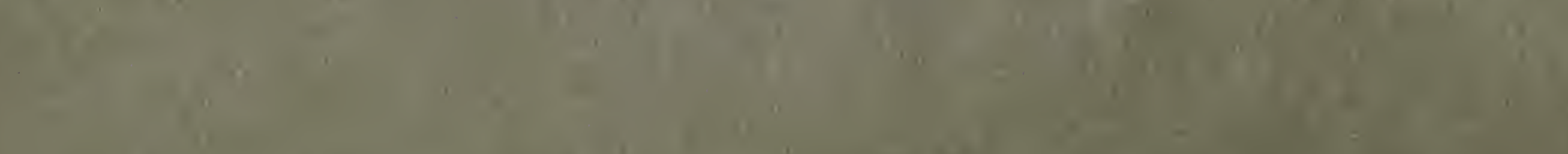

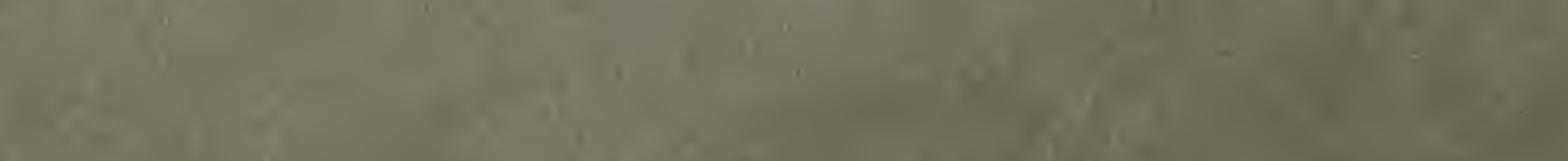

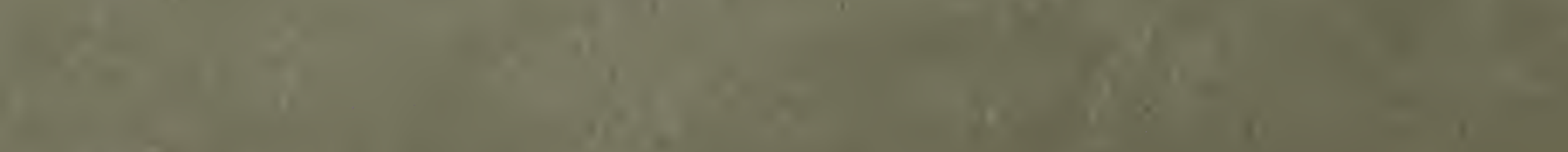




\section{Annual Report of the Director of Gardens for the Year I92I.}

The following gave their valuable services upon the Committees for the Management of the Gardens:-

Gardens Committee, Singapore: Mr. D. BentTr (to January 22nd), Mr. P. Cunliffe (to May inth), the Hon'ble Mr. V. Grbions (from February $9^{\text {th }}$ ), Mr. W. G. Hennings (to September I2th), Mr. J. G. Hubback (to April Ioth), the Hon'ble Dr. Lim Boon Keng (to September 2nd), the Hon'ble Mr. J. H. W. Park (from June 28th), Sir John C. Peter (from June 28th), the Hon'ble Mr. F. J. Pigote (to March 25th), Mr. J. W. Sime (from June 28th), Mr. W. A. Srms (from June 28th), and Mr. E. C. H. Wolff.

Committee for the Management of the Waterfall Gardens. Penang: the Hon'ble the Resident Councillor (Mr. G. A. Hall), Mr. Lawrie C. Brown, Mr. J. D. Fettes, Captain H. M. S. Haughton (to September igth), Mr. F. T. Kinder (from September Igth), Dr. P. Liston, Mr. Hastings Rhones, and Mr. C. R. Samuel (from September 29th).

The Director of Gardens is ex-officio upon both committees.

\section{Labour.}

Labour was plentiful. The coolies' wages were reduced in Singapore from 70 cents per diem, to 55; and the wages of gardeners were reduced also. The reductions were recognised by the men as inevitable, and did not cause any serious break in the labour force.

As the budget estimates for the year had been prepared upon a high wage, the reduction made it possible to employ additional men who were used for the work of deepening the Lake and for filling the two ponds below it. In the Government House Domain the surplus funds lapsed.

In Penang wages were reduced by two cuts to 5.5 cents. The money there freed, enabled the work of restoring the Fern-Rockery to be prosecuted.

\section{Revenue and Expenditure.}

The revenue in Singapore was $\$ 2,572.93$ by ornamental plants, and $\$ 464.63$ by economic plants: out-of-pocket expenses caused by the sales and recovered, amounted to $\$ 825.26$, making $\$ 3,862.82$. The amount paid into the Treasury in Penang was $\$ 1,067.17$, being $\$ 929.20$ by the sale of plants and $\$ 137.97$ by recoveries.

\section{Buildings.}

The Department in the first quarter of the year entered into possession of the new building containing the Director's office, library and laboratory.

\section{Investigations and Collections.}

Living collections.-The Department's thanks to the following donors are here recorded:-Drs. P. S. Cramer, F. W. Foxworthy, H. J. Gibbs, and Lim Boon KenG; Professors Harrison Smith and J. F. Rock; the Hon'ble Mr. J. Mitchell; Mrs. Anthony, Mrs. Burkill, Mrs. Flippance; 
Messrs: Abdul Kadir, Ahmed bin Hassan, Lawrie C. Brown, P. L. Chaffanjon, A de Villele, St. V. B. Down, David Fairchild, G. Farmer, W. P. Handover, A. Montefiore, G. P. Owen, B. K. Saheb, and C. L. WrAGGe; the Royal Botanic Gardens, Kew, the Botanic Gardens, Brisbane, Buitenzorg, Port Darwin, the Seychelles and Trinidad; the Departments of Agriculture, Bombay, British North Borneo, Egypt and the United States of America; the Chief Conservator of Forests, Nyasaland; the Deputy Conservator of Forests, Lakhimpur, Assam; the Forest Ranger, Larut; and the firm of MM ANDRIEUX-VILMORIN et Cie.

Living plants were brought into the collections from Selangor by the Director and by Mr. Best; from Penang Hill by Mr. FlipPance; from Lankawi and Terutau by Mr. MaHomed HANIFF and from Sibolangit, Sumatra, by the plant-collector Mahomed Nur, working under Dr. Foxworthy and Mr. LOERZING.

The entries in the "Plants-inwards" books were I,I4I in Singapore, relating to $I, 47 \mathrm{I}$ plants and I, I9I packets of seed, 160 in Penang, relating to I,80I plants and 149 packets of seed.

The Gardens played a part in the introduction into cultivation of the anti-leprosy plants, Gynocardia odorata, Taraktogenos Kurzii and Hydnocarpus spp., raising plants from the seed which the Department of Agriculture, U. S. A., collected by the agency of Professor Rock. Professor Rock proceeded through Siam, Burma and Assam in the quest of the seed; and that the result of his labours might not.be lost through the death of the seed in transit, he selected a few Gardens as recipients, one being Singapore's. The seedlings were easily raised, thanks to Professor Rock's care in collecting seed, and are now well established. The writer some years ago with the assistance of Dr. D. Hooper was also ablé to show that seeds of Gynocardia odorata only come into the market dead, and the oil rancid, because the seed is so carelessly collected.

The Jardin Colonial of Laeken supplied seed of Congo coffees, and of Congo Elæis. The Department of Agriculture, Ceylon, supplied some excellent races of the sweet potato. The Department of Agriculture, U. S. A., gave seed of Avocado pears of repute. By exchange excellent samples of some Burmese orchids were got from the Botanic Garden, Maymyo The Conservator of Forests, Nyasaland, was so good as to supply seed of the Mlanji Cedar, Widdringtonia Whytei.

This interesting and desirable Conifer has not succeeded in Singapore; but there is a seedling alive in the Waterfall Gardens, Ptnang, which Garden as regards Conifers shows a more suitable climate than Singapore; so that Cupressus glauca grows well in it, whereas it has been lost from the Singapore Gardens; and Pinus Mcrkusii planted in it has reached twenty feet in height, whereas it has stopped growing in Singapore at five feet.

Casuarina sumatrana gave a welcome supply of seed in Singapore, and has been reproduced.

A gratifying success in Singapore has been with Caryocar nuciferum, of which the first seedling now exists. Caryocar villosum is growing well in Singapore.

Pests.-Pests were very troublesome in Singapore towards the end of the year, when there was an outbreak of the palm beetle Protocerus colossus, accompanied by some abundance of Rhynchophorus ferrugineus and Oryctes rhinoceros. It is thought that the unusual dry weather in July favoured them. The following palms were attacked by the Protocerus, - Archontophœnix Alexandre, Attalea Cohune, Chrisalidocarpus lutescens, Cyrtostachys Lakka, Elais guineensis, Licuala horrida and L. Rumphii, Livistona Hoogendorpii and L. Kingiana, Phonix humilis var. Rœbelinii and Sabal princeps. At the same time Rhynchophorus ferrugineus was found in Phoenix dactylifera, $P$. zeylanica and Livistona chinensis; and larvæ of one or of the other, but too immature for certainty, were extracted from the stems of Orania regalis and Stevensonia grandis. 
The attack was got under in a couple of months by handpicking.

It is Oryctes rmnoceros which makes the tunnels into palms that Rhynchophorus ferrugineus uses for egg-laying; and it seems probable that the same happens with Protocerus colossus. Several years ago Mr. RidLey recorded that the Khinoceros beetle can mature in rich humts; in the course of suppressing the attacks described, an instance of this was found. Mr. RIDLEy upon another occasion remarked that palms in the Gardens died slowly some short time after an unusual spell of dry weather; is it not possible that the dying then was due aiso to an outbreak of Protocerus colossus?

Orchid beetles were troublesonie. A caterpillar probably of the genus Zeuzera was extracted from the branches of a wild Litsea and from the branches of the Avocado pear. Papilio polytes did some damage to Citrus trees in February.

The Gardens' only plant of Warczewiczia suffers considerably from the attack of an insect which damages the foliage; it was observed that while the lake was half empty the attack abated.

Dry collections.-Herbarium specimens were gratefully received from the Bureau of Science, Manila (II38), from Mrs. and Miss Burkill (I4O Sumatran plants), the Botanic Gardens, Buitenzorg (324), the Botanic Gardens, Brisbane (100), the British Museum of Natural History ( 82 plants of New Guinea), Professor Oakes Ames, Cambridge, Mass., (72), the National Herbarium, Pretoria (I4 fungi) and Dr. WeIr, Washington, U. S. A. (I8 fungi). Photographs of plants were generously given by Mr. E. GatTeY, Mr. W. Makepeace, Professor J. F. Rock and Mr. E. H. Wilson, and drawings by Miss A. M. Burkill.

Herbarium specimens were sent out as follows:-

$\begin{array}{llll}\text { to the Royal Botanic Gardens, Kew } & \ldots & \ldots & 64 \mathrm{I} \\ \text { to the Bureau of Science, Manila } & \ldots & \ldots & 55 \mathrm{I} \\ \text { to the Botanic Garden, Buitenzorg } & \ldots & \ldots & 450 \\ \text { to the Forest Research Officer, Kuala Lumpur } & \ldots & \text { 100 } \\ \text { to the British Museum of Natural History } & \ldots & 98 \\ \text { to Harvard University, Cambridge, Mass. } & \ldots & 75 \\ \text { to the University of California } & \ldots & \ldots & 64 \\ \text { to the University of Cambridge } & \ldots & \ldots & 60 \\ \text { to the Arnold Arboretum } \ldots & \ldots & \ldots & 50 \\ \text { to the Botanic Gardens, Brisbane } & \ldots & \ldots & 45\end{array}$

and for the favour of determination to Prince RoLiand Bonaparte, 33 ferns, to Mr. H. N. Dixon, 3 mosses, to Mr. G. C. Lloyd, 8 fungi, to Professor C. F. BAKer, 3 coccids, and to Miss G. Lister, I myxomycete

$\cdots$

\section{Botanic Gardens, Singapore.}

A vote of $\$ 700$ had been taken for a slight cleaning away of silt at the the upper end of the lake when the Anti-mosquito Committee, as a preliminary to work which they wished done on the ponds in the adjoining Tyersal grounds, approached the Gardens Committee on the subject of the lakes and ponds in the Gardens. The result was an undertaking on the part of the Gardens Committee to fill the Nelumbium and Limnanthemum ponds at the foot of the lake with the silt to be got from the Gardens' Lake, and a recommendation that the Cluny Lake should be filled also. With a reduction in coolies, wages in sight, the Gardens Committee saw the possibility of accomplishing the filling of the ponds by means of savings on the Gardens' labour bill, and that at the same time a much more effective deepening of the lake could be brought about than the small vote of $\$ 700$ promised. Meanwhile the Municipality was able to come to an agreement with the State of Johore, as landlord ot Tyersal, for the draining of the Tyersal ponds; and as it was desirable to await operations there before beginning in the Gardens, and also to get wages down, a commencement was postponed until June Ist: but from that date to the end of the year the Gardens lake was kept only half filled, while 
a special gang of coolies dug the accumulated mud of fifty years from the shallower parts of the lake-bed. The Nelumbium pond was soon filled; but the lake did not supply filling enough for more than two-thirds of the Limnanthemum pond.

Upon the inflow from the Tyersal ponds to the Gardens lake two pools existed in the Dell. The level of their waters was above the bed of the Tyersal ponds, and they were kept filled only because the sluice from the Tyersal ponds had been allowed to get out of order, the water escaping instead through the masonry above it. It was conceded that the Gardens had no right to the accidental head of water which made the feeding of the pools possible; and consequently alterations in the Dell became necessary upon the draining of the Tyersal ponds. To maintain the Dell, therefore, the two pools were lowered and dug into one, and connected with the inflow and with the lake by 2 feet culverts admitting fish freely; the sides were concreted; and the coral banks, now higher and steeper, were rebuilt. This made the dell-pools to such an extent a part of the lake as to be in no way a source of mosquitoes. The spoil from this work also went into the Limnanthemum pond.

At the foot of the Lake Niven's 5 feet high escape channel towards Holland Road was blocked up, and the small escape channel towards Napier Road was doubled and provided with an overflow pipe, dropping below the escape channels so as to carry away all the water. In doing this work the surface of an old roadway was discovered i8 inches under ground, leading towards the junction of Napier and Holland Roads. That roadway, which must have been closed in 1866 , is not on any existing map of the Gardens.

The sides of the islet were steepened; the Wormias on it were cut out, and Randia macrantha and Bougainvillce planted in their place. The latter however will not grow there.

It is of passing interest to remark that the following weeds came up on the exposed mud, and reached flowering in 65 days,-Jussice fissendrocarpa, Vandellia crustacea, Euphorbia aspera and Panicum indicum; and that these sedges and grasses reached flowering in 80 days,-Elcusine indica, Paspalum conjugatum, Paspalum platycaule. Ischromum Ridloyi, Cyperus Haspan, C. Irya, C. umbellatus, Kyllingia nonocephala, and Fimbristylis estivalis. Panicum indicum showed the phenomenon of vivipary. There stands on the bank of the lake a tree of Albizzia moluccana, and the half of its seeds fall into the water: many of them germinated on the exposed bank at the south end of the lake, to which they had been floated; and it was most interesting to find that in the soil which had been for years submerged they produced the nitrogenous tubercles of the Leguminose. On the bank above them Desmodium triflorum of the same order existed, and became more vigorous as the subsoil below it became drier.

Borassus Machadonis flowered in June near the Plant-house.

Four large trees were lost by storms, and the big Pterocarpus indica on Lawn $\mathrm{E}$ died of Angsana disease. The disease still remains obsctre.

The number of ornamental plants sent out from the Gardens was I6,48I and the packets of seed 773 .

By the kindness of the officers, the "band and the drums of the South Staffordshire Regiment played four times a month in the Gardens, the cost being met by the Municipal Commission.

\section{Economic diarden, Singapore.}

No tapping was done: there was an application for a lease of the rubber trees which was refused. All attempts to graft the selected rubber trees failed, partly in consequence of flooding, and partly from unknown causes. The attempt to graft will be renewed at a place away from the area liable to flooding.

Theobroma pentagona fruited. It is poor-yielding cacao. The Brazilnut trees which are oldest bore abundantly. 
The plantains imported from Manila began to fruit, proving our best races also theirs.

Experiments with garden vegetables were continued, particularly with lettuces. Carrots grew unexpectedly well.

The Government's decision to build the Raffles Memorial College in the Economic Garden overlies everything connected with it. The attempt is being made to propagate in any possible way the good plants that are in it; and an application has been made for permission to transfer them to a new site.

Of economic plants 1,532 were sent out in I92I and of seed 202 packets.

\section{Waterfall Gardens, Penang.}

Mention has been made above of the cut in wages which enabled extra labour to be employed; it permitted the employment of about eight men beyond the average of previous years, with the help of a small sum transferred from a Singapore vote. The work of four of these men went into the restoration of the Fern-Rockery, and of three into better mowing. The amount of sweeping was increased towards the end of the year.

The Fern-Rockery is now again well on the way to becoming the beauty spot that it was.

At the top of the Swimming-bath gully a rustic bridge has been built and rockeries made at the ends of it with flowering plants on them. Additional flower-beds have been dug around the Bandstand hill. The nursery was partially overhauled; and shrubs were planted on the big bank over the entrance gate.

The lower roads wure coated with Tarco. Many of the old Pandans were removed from the upper part of the Gardens. The Eucalypts perish one by one, and another was lost. The hill-top where the bungalow once stood, was partially cleared and vistas cut towards the Waterfall and towards the island of Pulau Jerejak.

Xylopia Curtisii flowered in the Gardens, and so did Hydrangea Hortensia.

The Municipal Commissioners in November consented to let, at a nominal rental, to the Gardens the block of land at the Gardens' gate whereon was the Vegetable Farm. As soon as possible it will be brought into a tidy condition, the better to preserve the amonities of the place. The part near the road will be planted with ornamental shrubs; and the part at the back used as a nursery.

The cataloguing of the plants in the Gardens is in progress, Mr. HanifF being responsible for numbering the trees and for collecting material for the purpose of determination or authentication.

There were sent out 2,626 plants and I63 packets of seed, which is a slight increase on 1920 , but less than in the years before.

\section{Government House Domain.}

After trying in vain all sorts of expedients to stop tresspass over the grass in the Domain, a watchman was engaged in October. It will be necessary to retain him permanently.

A motor mower was. put into use; but it cannot yet be regarded as a success. The rubber plantation within the Domain towards the Municipal Filter-beds was removed, and many trees of Poinciana regia planted among the remaining tembusu trees. The golf course was diverted towards that side, and the area brought into a better condition. New beds were dug on the upper lawns, and filled with Cannas. Several trees were removed having grown too big for their places, and some were lost by storms, notably in the south-west corner by Kramat Road, where it is necessary to raise up a fresh screen against certain very $u g l y$ buildings.

\section{HENRY BURKILL,}

6th July, 1922. [No. 5495/22.]

Director of Gardens. S. S. 





\title{
STRAITS SETTLEMENTS.
}

\section{ANNUAL REPORT}

OF THE

\section{DIRECTOR OF GARDENS,}

\section{STRAITS SETTLEMENTS,}

\author{
FOR THE YEAR
}

1922

BY

1. HENRY BURKILL, M. A.

Direcior of Gardens, Straits Settlements.

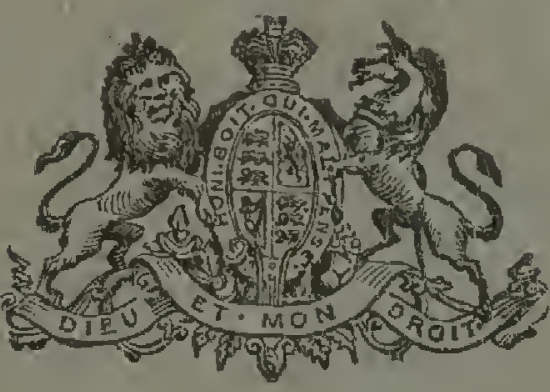

PUBLISHED BY AUTHORITY.

Sillgapofe:

Priated at the Government Printing Office, Singarore,

by J. E. TYLER, Government Printer:

6923. 


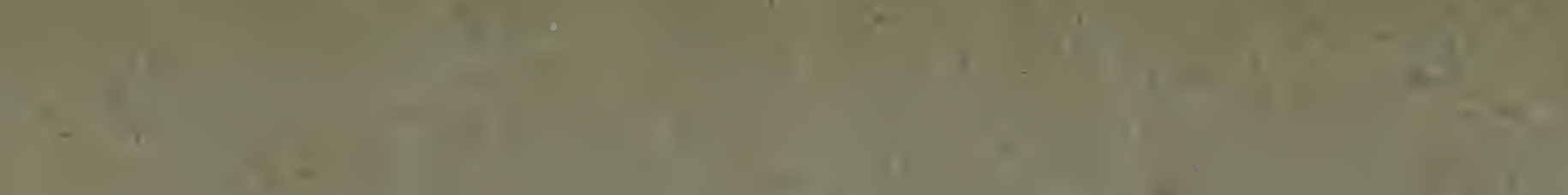




\section{Annual Report of the Director of Gardens for the Year 1922.}

The Committees for the Management of the Gardens were constituted as follows, and an acknowledgment is due to all who kindly gave their services :-

$$
\text { Gardens' Committee, Singapore: }
$$

The Hon'ble Mr. V. Gibions to May 8 th.

Mr. W. E. HoOPER, from June 23rd.

The Hon'ble Mr. W. Lowther Kemp from June 23 rd.

The Hon'ble Mr. J. W. H. Park. Sir John Peter.

Mr. J. M. Sime to April i7th.

Mr. W: A. Sims.

The Hon'ble Mr. E. C. H. WolfF.

The Director of Gardens.
Committee for the Management of the Waterfall Gardens, Penang:

The Hon'ble the Resident Councillor Mr. G. A. HaLl to September gth.

Mr. R. ScotT from September Ioth to November I6th.

Mr. A. B. Voules from Novemiber I7th.

Mr. LAWrie C. Brown

Mr. J. D. FETTES to March 20 th.

Mr. F. T. Kinder to August i7th.

Dr. P. LISTON.

Mr. Hastings Rhodes.

Mr. A. Rogers from August i8th.

Mr. C. R. Samuel.

The Director of Gardens

On July izth Mr. R. E. Holttum joined the Gardens' staff as Assistant Director. 'Throughout the year Mr. F. FLIPPANCE' held executive charge of the Waterfall Gardens, Mr. G. A. Best of the Botanic Gardens, Singapore, Mr. E. L. Shaw of Parks, Singapore, and Mr. J. Lennon of the Economic Garden, Singapore. One of the two posts of Field Assistant was vacant.

\section{Labour.}

Labour was obtained at the reduced wages of the second half of I92I, with somewhat less coming and going than in that year: but still the Singapore roster shows 2 ro new engagements in the twelve months, which means that the labourer on the average stays but eight months.

\section{Revenue and Expenditure.}

The revenue made in Singapore by the sale of plants and seeds was $\$ 2,634.37$ : of it $\$ 1,577.29$ came from the sale of ornamental plants, $\$ 506.88$ from the sale of economic plants and $\$ 541.49$ from recoveries of transport expenses and from miscellaneous sales. Nothing was made out of rubber.

The revenue made in Penang by the sale of plants and seeds was $\$ \mathrm{I}, 062.93$, being almost entirely from the sale of ornamental plants. 
The Municipalities of Singapore and of Georgetown, Penang, contribute towards the upkeep of the Department $\$ 300$ and $\$ 1,200$ respectively in return for advice upon roadside trees, etc.; and the Municipality of Singapore, further, meets the expenditure incurred by reason of music in the Gardens.

Expenditure in Singapore was greatly reduced: the cost of labour was $\$ 18,315$ against $\$ 33,294$ in 1921 : and of stores, tools, travelling, books and book-binding $\$ 14,013$ against $\$ 17,235$.

Half of this reduction had been anticipated in preparing the estimates: the other half was by savings effected during the year.

The expenditure on labour in Penang was \$9oo less than in I92I and upon stores, tools and miscellaneous $\$ 560$ less.

\section{Investigations and Collections.}

For many years the local rainfall has been read in the Botanic Gardens, Singapore. From September, I922, the observations were extended to temperature, evaporation and humidity, the instruments having been supplied by Dr. Gilbert Brooke, and the readings are daily transmitted to him for official record.

Living collections.-For gifts to the Department of plants or seeds, the following are here publicly thanlied:-

Lady Guiliemard, Mr. K. J. Bask of Mullumbimby, Australia, Mr. E. Bateson, Mr. L. C. Brown, Mr. G. Davidson (H. B. M.'s Consul at Para), Captain H. Berkeley, C.B.e., Mr. W. Dunman, Mr. L. de Cotta, Mr. H. Cundr, Mrs. F. Flippance, Mr. W. J. C. Frost, Mr. P. Fedderson, Mr. H. j. Eley, Mr. F. T. Kinder, Mr. G. P. Owen, Mr. B. K. Sahib, Mr. V. G. Savi, Lient.-Colonel R. L. B. Thompson, c.M.G., Mrs. G. W. A. Trimmer, Dr. G. H. Trennon of Thursday Island, Mr. Way, Messrs. Afmed bin Hassan, Ahmed bin Hadji Omar and Abdul Kadir of Singapore and a number of Malay and Chinese exhibitors who at the close of the MalayBorneo Exhibition allowed the Department to select from their exhibits; the Royal Botanic Gardens, Kew, Calcutta and Peradeniya; the Botanic Gardens, Buitenzorg, Cambridge, Port Darwin, and Saigon; the Jardin Colonial of Laecken, and Mr. A. Robertson-Proschowsky of the Jardin d'Acclimatation "Les tropiques" at Nice, the Chief Forest Officer, Zomba, British Central Africa; and the Director of the Amani Experimental Station, Tanganyika territory: the Conservator of Forests, S. S. and F. M. S., and his officers; M. M. Andrieux-Vtlmorin et Cie., the Arnold Arboretum, Jamaica Plain, Mass., U. S. A., the Department of Agriculture of the United States, and the Experimental Stations in Hawaii and Porto Rico.

Owing to identity of climate between the south of the Malay Peninsula and the lower Amazon valley, an exchange has long been sought with the Botanic Gardens, Para, but cannot be obtained. In default of this the kindness of Mr. DavidSON in sending seeds is greatly appreciated.

Mr. Frost gave to the Waterfall Gardens a large consignment of Dendrobia from the South Sea islands in return for assistance rendered earlier in connection with collecting.

Mr. G. H. Vernon's gift of a large plant of Dendrobium Johannis was much appreciated. It was exhibited at a meeting of the Singapore Natural History Society and a note upon it will be found in the Society's transactions. The seed of Widdringtonia Whitei which the Chief Forest Officer, Zomba, so kindly procured, has given a supply of seedlings: they are being: carefully nursed. The Director of the Amani Experimental Station supplied seed of Vitex Volkensii which yields a new drug; seedlings have been raised.

Casuarina Rumphii was successfully raised from seed from Buitenzorg: Kew and Cambridge supplied collections of Kalanchoe. 
The Department brought into cultivation plants from Gunong Tahan, from the Semangkok Pass, and from the hills near Seremban and Gunong Tampin. Further the Director brought back plants from Gunong Gedeh in Java, whither he had gone on short leave in May, and Mr. FLIPPANCE brought plants back similarly from Kedah. The Plants-inward book in Singapore records the receipt of 1,874 plants and 913 packets of seed; and in Penang records the receipt of 2,304 plants and 234 packets of seed.

Hydrangea Hortensia flowered and Coelococcus carolinensis fruited in Singapore.

Captain BERKELEY's gift was of seed of a small Rubiaceous shrub used as a substitute for coffee in Upper Perak. The young plants raised are yet too small for determination.

The Royal Botanic Gardens, Kew, sent seed of Picralima Klaineana, a tree which provides a widely-used African remedy for fever. At present the seedlings are 6 inches high.

Pests.-Two orchids suffered much during the year from the attacks of beetles: they were Calanthe veratrifolia which was attacked by an Aorocrypta and Spathoglottis plicata which was attacked by a Hispid other than the common Gonophora.

A Coccid was bad on Hibiscus and a caterpillar an Cassia fistula.

A beetle found destroying Shorea seed proved to be a species of Aleides.

The determinations of the insects above were received from the Holnourable Mr. C. J. SAunders.

Dry Colloctions. - Advantage was taken, als follows, of opportunities of collecting in various parts of the Peninsula. The Director collected at Port Swettenham and in Penang (March I I-20); Mr. Molnamed Haniff on Gunong Tahan (May 2oth_-June ISth); the Director at Port Swettenham and in Penang (June I7th-26th); the Director and Assistant Director together, about Fraser Hill, in Kuala Lumpur, Penang, Province Wellesley and Port Swettenham (September I5th-October IIth); the Assistant Director in Central Johore and Negri Sembilan (November ${ }_{15}$ th-December $5^{\text {th }}$ ); the Director near Kuala Lumpur and in Penang (December 5th- I3) Mr. BEST and the Gardens' plant-collectors on Gunong Pulai 'April 24 th-26th and December 28th.)

Further while on leave the Director made a collection of dry plants upon Gunong Gedeh, Java, which has been incorporated in the Gardens' herbarium.

Mr. H. C. Robinson gave very kindly help to Mr. HanifF when visiting Gunong Tahan.

The following herbarium specimens were sent out:-

to the Royal Botanic Gardens, Kew $\quad \ldots \quad$... 758

to the Bureau of Science, Manila $\quad \ldots \quad$... 718

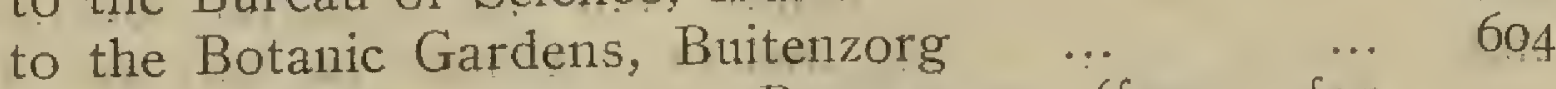

$\begin{array}{llllll}\text { to the Prince ROLAND BONAPARTE (ferns for } & \\ \text { determination) } & \ldots & \ldots & \ldots & 296\end{array}$

to Mr. G. C. Lloyd (fungi for determination) ... 235

to the Royal Botanic Gardens, Calcutta ... $\quad \ldots \quad r 74$

to the Forest Department, Kuala Lumpur ... I3I

to the Arnold Arboretum, Jamaica Plain, Mass. ... I. I24

to the Botanic Gardens, Brisbane ... $\quad . . . \quad$ I0 8

to Mr. H. N. Dixon (mosses for determination) ... Ioo

to the British Museum of Natural History $\quad \ldots \quad 99$

Carried forward $\quad \ldots \quad 3,347$ 
Brought forward $\quad \ldots \quad 3,347$

to the University of California $\quad \ldots . \quad \ldots \quad 70$

to Professor Oakes Ames, Cambridge, Mass ... 55

to the University of Cambridge, England $\quad \ldots \quad 46$

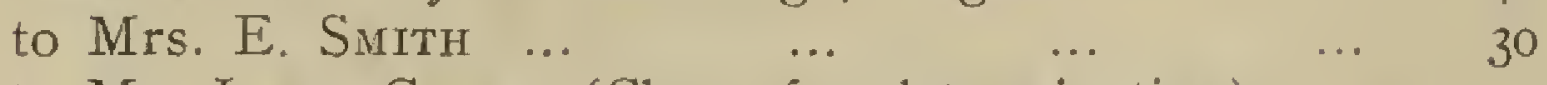

to $\mathrm{Mr}$. James Groves (Chara for determination) ... I

Total $\quad . .3,549$

and also II 3 hand-samples of timber to nine of the departments or institutes named above.

The help in determining plants given by those named above is gratefully acknowledged, and also similar help from Mr. E. D. Merkill, Director, Bureau of Science, Manila, and Dr. J. J. Smith, Acting Director of the Botanic Garden, Buitenzorg.

Coccids have been sent to Professor C. F. Baker and Dr. Harold MORRISON.

Mounting paper being again obtainable, three women have been employed to assist in the mounting of the herbarium collections, in order to reduce the great accumulation of inaccessible specimens. It is anticipated that in 1924 these, which are war arrears, will exist no longer.

Herbarium specimens were received from the Royal Botanic Gardens, Kew (48) being duplicates of a collection made by Mr. RIDLEY in I920 - I92I; from the Bureau of Science, Manila (I358); from Mr. A. Marcan (I40); Mrs. Sмiтн (325) and Luang Winit Wanddorn of the Department of Forestry, Siam (64); and lastly fungi to the number of 210 from the Department of Agriculture of South Africa.

Drawings of plants were kindly supplied to the Department by Mrs. Newnham and Miss. A. M. Burkill; and a photograph by His Excellency Major-General Sir Nerll Malcolm.

Books and pamphlets were kindly given to the Department by the Colonial Government, the Governments of India, Java, Corea, Formosa, Queensland, South Africa and Brazil; by Dr. Docters van Leeuwen, Mr. J. G. Beaumee, Mr. F. M. Bailey, Mr. D. H. Imminck, Mr. G. B. Deshmuki, and others; and by the Malayan Branch of the Royal Asiatic Society, the Singapore Natural History Society, and the Editor of the Gardens Bulletin and many institutions which regularly send their publications. The books bound wert not so many as had been hoped, so that large arrears still exist.

\section{Botanic Gardens, Singapore.}

In January the removal of silt from the Lake was finished, but the Limnanthemum Pond was not filled by it. To fill it, the area of the sun-rockery was enlarged, and the site of a second propagating orchid-house dug out: and these, which were works long contemplated, furnished filling. The whole area of the old pond was then planted up with red and yellow cannas, and they became very effective. The sun-rockery was provided with hard sandstone terraces and pkented, as far as the Gardens' stock of suitable plants permitted: but it will be some little time before it can be considered as "made," for many plants have to be procured. Late in the year it was arranged that an anti-mosquito vote should meet the cost of filling the Cluny Lake, and work thereon was commenced. The source of the filling is the future site of the Gardens' subordinates' quarters, and the Tamil lines. The lake itself is destined to become a nursery.

By using the glass of old almeirah-doors, a new place was prepared in the potting yard for seed-germination and much is hoped of it: the attaped corner formerly used, was too damp and too dark. 
The By-laws of the Botanic Gardens, Singapore, were revised and republished in the Straits Government Gazette of November Ioth, I922. . The alterations made declare the Gardens closed at one hour after sundown, forbid the entrance of lorries and 'buses, raise the permissible pace of vehicles ito I5 miles per hour, assert clearly that wild life has sanctuary in them, and define better the controlling authority. As there are two dwelling houses within the Gardens to which vehicles at times need access, a short service road is being laid down by which lorries can reach them and when it is ready the By-law forbidding heavy vehicles entry over the other roads will be strictly enforced.

A violent squall in the early morning of May gth overturned thirteen trees in the Botanic Gardens and four in the Economic Gardens. Five weeks later some one maliciously uprooted a number of new plantings. Eighteen cases of theft came under investigation and approximately the same number of thieves were convicted.

Planting of the sun-rockery was done in August. One side is given to Agave and Aloe: the other to succulent Euphorbiaceae, Cacti and Kalanchoe. The lowest terrace is temporarily filled with Zephyranthes. The islet in, the Lake, cleared of Wormia and planted partly with Randia macrantha, was further planted with tree ferns and Vandas. Many waterlilies were put into the lake. The last of the Dell rockeries was planted up.

The number of plants sent out was 10,977 and of packets of seed 217 . Two wardian cases were sent out, one to Kew and one to Peradeniya.

The Band and the drums of the 2nd. Middlesex Regiment played regularly in the Gardens, and the Band of His Italian Majesty's ship "Libia" once, upon the kind offer of Commander BurzagLI, C.B. The services of the regimental band were obtained by the kind permission of Colonel F. E. Swainson and the officers.

Economic Gardens, Singapore.

The demonstration plots of vegetables were continued until the end o: the year, when they were closed down. Cultivation of the fruit-tree plot upon the hill-top was abandoned, and preparations made for the removal of some of the fruit trees. The small tree of Swartzia pinnata, which is the only one in the Gardens, was successfully transferred to the Botanic Gardens, though it is $\mathrm{I} 2$ feet high. Other similar trees have been prepared for removal by root pruning. The observation plots of tuberous plants under study were replanted upon the understanding that the land whereon they are will not be needed for other purposes until after the crops have matured.

There were sent out 7.18I economic plants and I53 packets of seed.

\section{Waterfall Gardens, Penang.}

The planting of the block of land outside the Gate which formerly served as a Demonstration Vegetable Garden, is in progress and when the shrubs have grown, the amonities of the approach will be restored: When occasion offers, some planting should be done upon the other site of the road also.

Half of the stag-headed Polyathia trees of the Lower South roart have been removed. In the neighbourhood of this road the stream had iretted its bank seriously and not a little labour has been put into strengthening it. A slipping has occurred at the Upper Dam, but is not serious yet: the slipping has caused the north end of the dam to be about an inch lower than it was originally.

Additional flower-beds have been made, crowning the bank over the stream at this spot. 
Pancratium and Zephyranthes have been used in the borders round Plant-houses I and 3 .

The Bathing. pool (no longer available for bathing) has been improved considerably by a cleaning out, by additional planting of water-lilies and by a new sluice. Impatiens Curtisii and $I$. Holstii do very well on its rockeries, and Staurogyne grandiflora has flowered in great profusion.

Warczewiczia coccinea flowered in the Gardens for the first time. Ouvirandra fenestralis gave seedlings. Rhododendron Teysmanii flowered in the fern rockery.

Five trees were lost, none irreplaceable.

It has become popular with visitors to feed the monkeys which visit the Gardens, and large numbers of cars drive round the Lower roads in the evening, even to well above roo a night between 5 and 7 p.m. The use of the Upper roads by cars has been forbidden since a serious accident occurred in March. That all manner of visitors should drive to the very top of the Garden had for long appeared undesirable on account of the damage done thereby to the roads and a notice board was put up in 1915 where the Upper South road takes off to direct them along the Lower Roads: but since the accident these upper roads have been closed and blocked by drop-posts. They have been narrowed and are good paths for pedestrians.

The number of plants sent out was 3,429 , together with 87 packets of seed: of the plants $\mathrm{I}, 377$ were officially plantings in Government ground outside the Gardens.

\section{Government House Domain.}

The year's work in the Domain has been a valuable one because under close supervision an accurate measure of the labour required has been obtained. làwn.

His Royal Highness the Prince of Wales planted a Royal Palm on the

\section{Roadside Trees and Parks.}

The arrangement with the Municipality of Singapore by which help is given with their roadside trees and park-lands is gradually taking shape; and that with the Municipality of Georgetown, Penang, is in full working order. Not a little new planting has occurred in both Settlements upon Government land. Many officers have the use or control of land on the understanding that they do not remove trees without permission; but as no inspection has existed, trees in the past have been removed unsanctioned. An inspection can be provided for now on the filling of the post of Assistant Curator, Parks.

Angsana disease has removed all the Pterocarpus trees from the Tanglin Bar racks grounds, except three which are isolated.

\section{Other Work.}

The Director of Gardens, and the Assistant Curator, Waterfall Gardens, Penang, have been gazetted Inspectors under the Agricultural Pests Ordinance, I9I8. with the intention that they should assist in the exclusion from the country of plants liable to bring in with them pests; and also they are empowered to give certificates of freedom from disease on plants exported to countries where such certificates are demanded in order to obtain import.

Much work was done for the Malaya-Borneo Exhibition chiefly in laying out the grounds, loaning plants, carrying through the Horticultural Section and furnishing two stands one to advertise vegetables and the other to advertise fruit trees. Also a considerable amount of decorating of public places both in Singapore and Penang was done by the Department during the Royal Visit.

SinGAPORE; 27 th February, I923. 



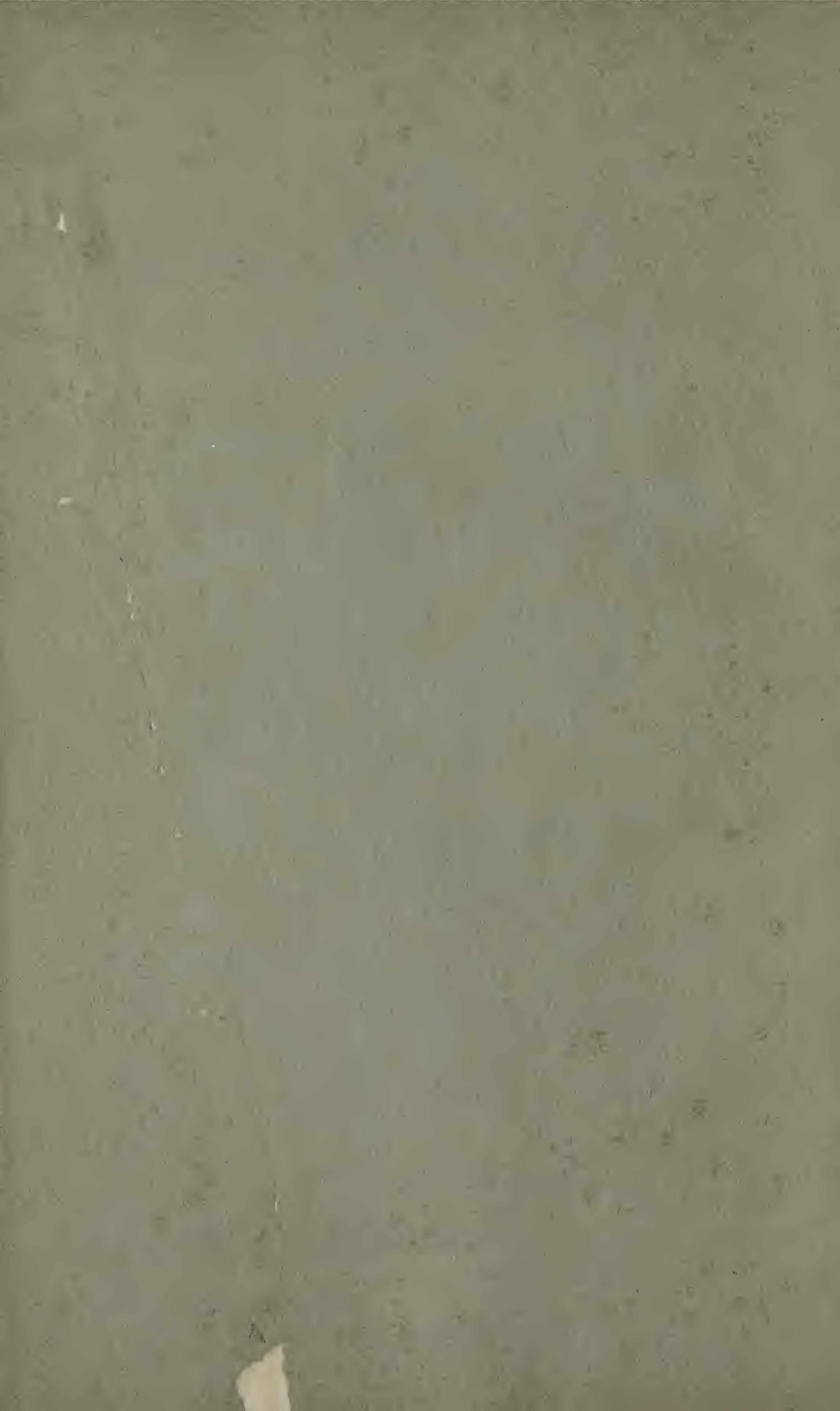




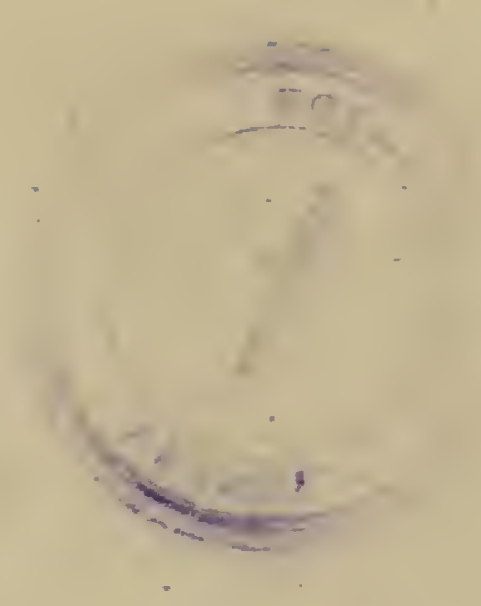

Report of the Director of Gardens for the year 1923.

The Gardens Committee, Singapore, consisted of Mr. W. Dunman (from November $13^{\text {th }}$ ), the Hon'ble Mr. V. GibBons (from March i $3^{\text {th }}$ ), Mr. W. E' Hooper (to February gth), the Hon'ble Mr. W. Lowther Kemp, the Hon'ble Mr. J. W. H. Park, Sir John Peter (to July 2oth), Mr. J: M. Sime (from March 13th), Mr. W. A. Sims (to September Ioth), the Hon'ble Mr. Song Ong Sinng (from May 3rd), and the Hon'ble Mr. E. C. H. Wolff (to April I3th), with the Director of Gardens. The Committee for the management of the Waterfall Gardens, Penang, consisted of the Hon'ble the Resident Councillor-Mr. A. B. Voules, Mr. Lawrie C. Brown, Mr. F. T. Kinder (March to October), Dr. P. Liston (January to May), Mr. Hastings Rhodes, Mr. A. Rogers (January, February, November, and December,) Mr. C. R. Samuer, and the Director of Gardens (to October 8th).

For their valuable services, thanks are due to the members of both Committees.

During the year an enabling enactment (Ordinance No. 8 of 1923) was passed by which the second Committee possesses the same powers as the first.

The Director of Gardens, Mr. I. H. Burkill, was on leave from February 27 th to October 26th, the Assistant Director, Mr. R. E. Holrtum, acting for him. Mr. F. Flippance held executive charge of the Waterfall Gardens until November roth, when he went on leave. Mr. G. A. Best served as Assistant Curator, Singapore Gardens, until that date, when he relieved Mr. Flippance. 'Mr. J. Lennon was appointed Assistant Curator, Parks, Singapore, from January ist, and was at his post through the year. Mr. C. X. Furtado joined the staff as Field-Assistant on April 4th.

\section{LABOUR.}

Sufficient labour was procurable both in Singapore and in Penang. A chinese gardener was added to the Penang force with the duty of raising ornamental plants in pots.

\section{REVENUE AND EXPENDITURE.}

The revenue paid into the Treasury in Singapore was $\$ 4,462.48$ : $\$ 1,324.28$ came from the sale of plants and seeds, $\$ 2,460$ from a six months lease of the rubber trees in the Economic Gardens, and $\$ 667.89$ from miscellaneous sources, including recoveries.

The revenue paid into the Treasury in Penang was $\$ 809.27$, of which $\$ 693$ came from the sale of plants and seeds, and the rest came from recoveries, etc.

It is of historic interest to record, that from 1915 to 1917 , inclusive, the Gardens in Singapore made a bigger revenue from economic plants and seeds than from ornamental plants and seeds, but that in 1918 this was reversed; and now with the closing of the Economic Gardens the revenue from economic plants almost ceases. 
The Municipalities of Singapore and Georgetown, Penang, contributed $\$ 300$ and $\$ 1,200$ respectively towards the cost of maintenance, in return for advice upon roadside trees, etc.; and the Municipality of Singapore met the cost of music in the Gardens.

Expenditure in Singapore was far below the votes, chiefly by reason of a reduction of the labour employed in the Economic Garden to one watchman, one mandor, and on an average 77 men per diem. Expenditure in Penang used up the whole of the votes for Penang; and they were supplemented by two amounts transferred from savings in Singapore.

\section{BUILDINGS.}

In Singapore quarters for six hindu watchmen, ten married tamil coolies, six subordinates, and a barrack for thirty unmarried men were erected, and occupied as socn as ready; whereupon the temporary lines for tamils in the Economic Garden and the condemned lines for the watchmen were abandoned and pulled down.

A Tea-kiosk was erected in the Gardens and gas was laid on tc the Laboratory.

In Penang Plant-house No. 3 was re-erected, plant-house No. ro demolished, and a new house built upon a more suitable spot.

\section{INVESTIGATIONS AND COLLECTIONS.}

Living collections.-For the gift of plants and seeds the following are thanked:-Messrs. Ahmed bin Hassan, and J. S. W. Arthur; Captain H. Berkeley, O.B.e.; Messrs. D. R. Boyce, L. C. Brown, and G. B. Deshmukn; Dr. F. W. Foxworthy; Mrs. Lim uf Union Street, Penang; Messrs. G. Rican, B. K. Sahib, C. L. Samuel, Akira Satow, Tan Chye Sian, Tan Tang Nran, and W. L. Wood; His Siamese Majesty's Consul-General; the Agricultural Experiment Station of Santiago de las Vegas, Cuba; the Botanic Gardens of Kew, Port Darwin, Buitenzorg and Kingston, Jamaica; the Departments of Agriculture of the United States and Union of South Africa, and the Superintendent of Horticultural Operations, Delhi, India.

The total number of plants inwards to Singapore was $72 \mathrm{I}$ with $5^{\mathrm{I}} 3$ packets of seed; and to Penang 936 with 315 packets of seed. The Director, when returning, brought with him four Wardian cases and three boxes of plants, containing I47 species as a gift from the Royal Botanic Gardens, Kew, and a number of supplementary purchases. By the kindness of the Director the whole had been assembled and packed at Kew.

At the end of the year 1922 the Chief Forest Officer, British Central Africa, supplied seeds of the Mlanji cedar; the seedlings are growing satisfactorily in Singapore; but they damped off in Penang. The Montezuma pine is one of the new introductions to the Gardens in Singapore.

Among living plants brought into cultivation in Penang as the result of a collecting trip in Kelantan, is a new and showy Dendrobium,D. Haniffi, Ridl. The Dendrobium mentioned in the last report as the gift of Mr. J. C. Frost, has flowered well and proved to be $D$. atro-violaceum.

Of the new species received in Penang in the form of seed from Delhi but few survived the seedling stage. What suits the climate of northern India is scarcely likely to suit that of Penang, and indeed in general does not.

In I9I8 it was discovered that the Gardens possessed a tree of Her'ea confusa; and lest it should hybridise with the Para rubber trees and so cause deterioration of the Gardens'. seed, it was removed as soon as determined. Two seeds from it were preserved and the resulting seedlings planted in the Botanic Gardens near the main gate; they flowered at the end of I923. and both were found to be hybrids. They were destroyed immediately, having served the purpose of showing how readily $H$. confusa and $H$. brasilicnsis cross. 
A planter alive to improvement of his crop will similarly destroy inferior stock from his estate, though one hopes none have trees whose progeny will yield rubber so badly as that of $H$. confusa.

In the place of these removed trees, two trees now stand, being grafts from the best of the Gardens' trees, Nos. 27 and 610. It is hoped to find them fertile to each other when they come into flower: secondly, upon Lawn $A$. two grafted trees, both from No. 27, have been placed close together to see how fertile it is to itself.

Herbarium.-Botanic exploration was directed to the less known floras of the Peninsula; one Expedition, undertaken by $\mathrm{Mr}$. Holtrum, was to Gunong Blumut in Johore, and another, undertaken by MoHamed Haniff, was up the Lebir river in Kelantan to the roots of Gunong Tahan. 'The results are being worked out. A report was published upon the collections made in 1922 about Fraser-Hill which has received a notice in "Nature". Subsequent to the preparation of it, the Forest Department undertook some investigations in the same region and a plant collector was attached to their party. The same collector was later attached to a zoological party working on Gunong Angsi in Negri Sembilan. The Assistant Director also was able to visit Frascr-Hill for a short spell, and Mr. BEST was able to make a short tour in Selangor. The accessions, by these departmental efforts, run to nearly 1,900 numbers, with plenty of duplicate material for exchange.

The exchanges that the Department makes are of the greatest importance at the present time; for without co-operation of this way between the several institutes studying the Malaysian flora there is much danger of confusion arising by duplication of names. The following table shows how many specimens were sent out in 1923:-

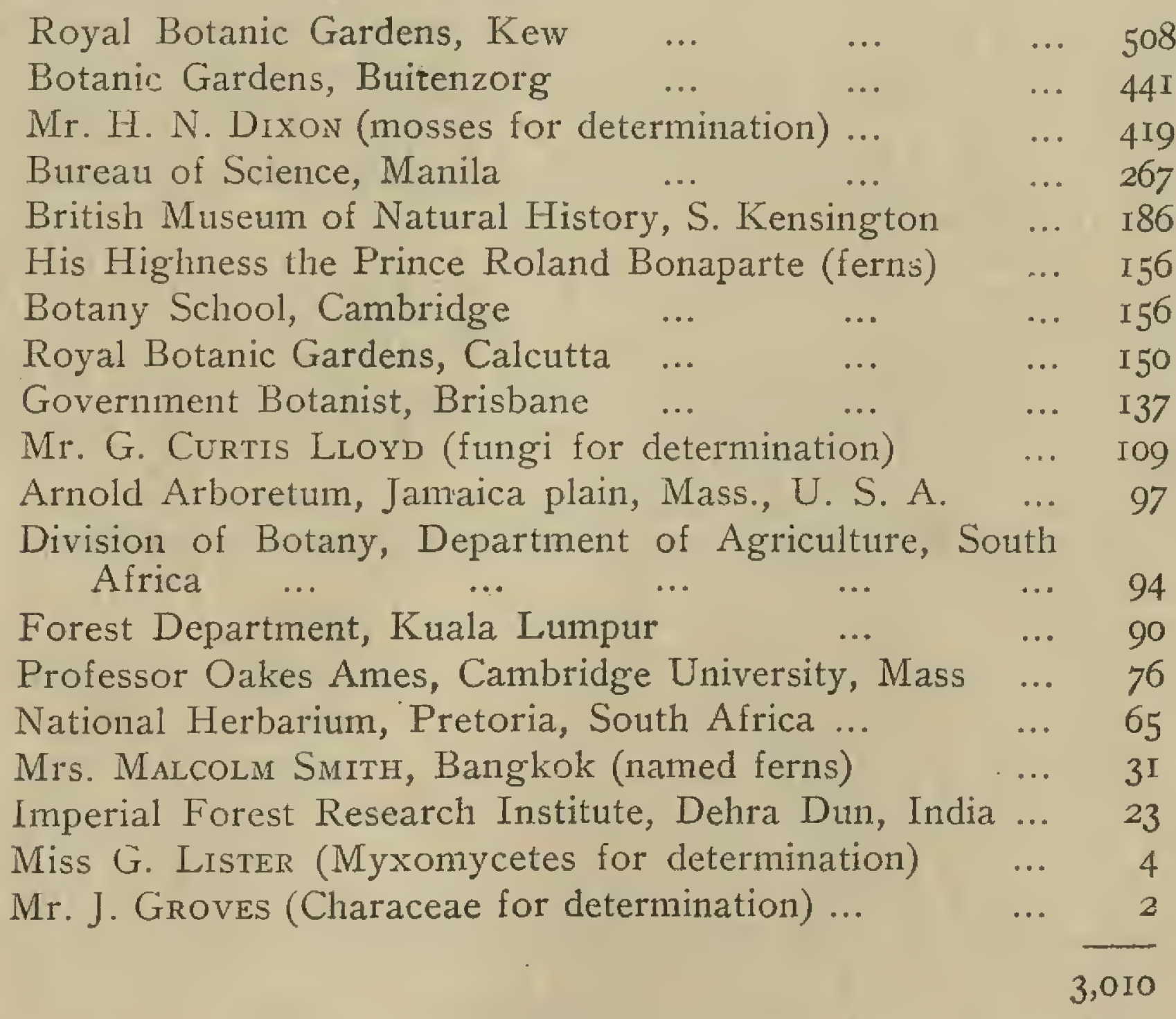

Hand-specimens of timbers to the number of 158 were sent out to many of the above along with herbarium material.

The department has received a large amount of help in the form of determinations of plants from Mr. H. N. Ridlex, Mr. H. N. Dixon and Mr. G. C. Lloyd, Miss G. Lister, and Mr. J. Groves.

Mrs. Malcolm Smith sent 430 specimens of ferns and lycopods. The Prince Roland Bonaparte supplied I04 specimens and the Forest Research Institute, Dehra Dun, 22: Mr. C. Boden-Kloss gave II, being Christmas and Cocos Islands plants. 
Mr. C. C. READE presented some illustrations of Australian plants, and Prince Roland Bonaparte a set of his publications.

Specimens of Dipterocarpus, Lauraceæ and Sapotaceæ were loaned to the Botanic Gardens, Buitenzorg, and have been returned named.

Library.-The arrears of binding have been overtaken, and the special vote for the purpose exhausted.

At the end of the year the Director of the Raffles Museum asked if the Gardens would receive and house on indefinite loan certain botanic works; and this was agreed to.

The library with them contains about 4,000 volumes.

\section{BOTANIC GARDENS, SINGAPORE.}

Two parts of the Lower Ring Road which had become too narrow for their increased traffic were widened by two feet; and in doing this an ugly elbow which disfigured the avenue of Red-stemmed palms, was obliterated. Close to this road the Tea-kiosk mentioned above, has been placed. It was leased out from November.

The bands of the Surrey and of their successors the Sussex, regiments played regularly in the Gardens.

- The orchid-propagating house, mentioned in the last report, as under construction, was completed. The condition of the orchids is improved by transfer to it.

The filling of the Cluny Lake was finished, and the laying out of its area commenced. A thicket to the west of it which concealed a rubbish pit, was cleared away and the ground smoothed and turfed. Planting was extended beyond it over lawn $Z$, and the path across lawn $Z$ carried forward through the trees which border Gallop road as far as lawn $R$. Palms are being planted among these trees.

Part of lawn $\mathrm{E}$ was smoothed and the foundations of an old rectangular building of unknown use removed from under the turf.

One of the largest trees in the Gardens, a Shorea parvifolia, No. 634, died, probably struck by lightning. Another of the very large tree of Shorca is badly attacked by Fomes tricolor, and is doomed. In December the monkeys apparently finding food scarce, did considerable damage to slender palms of the genus Ptychosperma by eating out the small cabbage.

The plants and packets of seeds sent out were-

$\begin{array}{lllcc} & & & \text { Plants. } & \text { Seed. } \\ & & & - & - \\ \text { Ornamental plants } & \ldots & \ldots & \text { I2,II5 } & \text { I08 } \\ \text { Economic plants } & \ldots & \ldots & \text { I,454 } & 52\end{array}$

Two Wardian cases full of plants were taken to Kew by the Director in March, and a third by Mr. Flippance in November.

\section{WATERFALL GARDENS, PENANG.}

An increased attention to the lawns, and an increase in the number of men employed in sweeping and similar operations, has improved the appearance of the Gardens. Unfortunately in the year under review this had to be done at the cost of other work: but it is provided for otherwise in the current year.

The land just outside the Gate, leased by the kindness of the Municipality to the Gardens at a nominal rent, has been made tidy; and as the Government permits planting upon the land facing it, an avenue is to be created leading up to the Gardens gate. 
The stream-bank between the office and Plant-house No. I, has been strengthened by stones in wire cages, and rebuilt in places. The old swimming-bath was cleaned out. The water-lily pond near the office which had grreatly silted up, was drained, and its dam demolished. For the plants which it harboured, there are other places in the Gardens. The water-lilies for instance have been beautiful in the old swimming-bath.

Of trees, two Arancarias were lost by white ants, and one Eucalyptus rorymbosa. A tree of Eugenia grandis near the Gate and the remaining Polyalthias of the Lower South road were removed, allowing the interplanted Delonix full space.

A scientific observation upon these is worth record before passing on. It is that of all the trees, the two which have made the most growth in the poor sandy soil are those nearest to the Rain-trees, which limit the aventue. It is probable that the shade of the well established Rain-trees, by increasing the moisture in the soil has had something to do with this: and extremely probable that the bacteria of root-nodules upon these have passed freely to the Delonix and benefitted them.

It is now some time since the Public took to feeding the monkeys in the Gardens, and since the monkeys, therefore, came to live almost permanently in the neighbourhood. Eating the young buds from the Albizzias by the nursery, they have killed some of the trees and have disfigured the others by leaving only the very slenderest and remotest branchlets.

Split bamboo was put upon the roof of Plant-house No. 2, on one side and bertam upon the other side; an experiment which will demonstrate their relative durability. taken.

There were two thetts of Adiantum farleyense, the whole supply being

The plants and packets of seeds sent out were:-

$$
\begin{array}{cc}
\text { Plants. } & \text { Seeds. } \\
3,059 & 447
\end{array}
$$

Among the plants sent out was a most interesting Amorphophallus, not much less in size than A. Titamum; and it is now established in the Waterlily house at Kew. Four Wardian cases were sent to Kew, and two boxes of plants.

\section{GOVERNMENT HOUSE DOMAIN AND OTHER CHARGES.}

The Edinburgh road in the Government House Grounds, Singapore. rom the Gate upon Orchard Road to the hill crest has been planted with an uvenue of Arfenillea arborescens alternating with Delonix regia and Peltophorum fermgineum. The youtig trees promise well. Planting has also been done on the edge of the Medical College grounds, in the Cathedral compound and elsewhere. A census of roadside trees in Singapore has been commenced with the object of co-operating with the Municipality in the betterment of the town avenues. The roadside trees of Pithccolobium Saman were very badly attacked by the Coccid, Phenacoccus iceryoides, and the Dclonix trees defoliated by the moth Pericyma Cruegeri; it is not easy to get either pest under. It is probable that the Phenacoccus has arrived newly from India.

Efforts are being made to get shorter grass upon the slopes of the Government House domain: for only when that is achieved will the motor mower be able to cut them effectively.

I. HENRY BURKLLT.

Director of Gardens S. S.

8th April, 1924. 



\section{Annual Report of the Director of Gardens for the year 1924.}

The Committees for the Management of the Gardens were constituted as follows:-(Gardens Committee, Singapore), Mr. W. Dunman, the Hon'ble Mr. W. Lowther Kemp, Mr. F. T. Kinder (from ith July), Dr. G. H. K. Macalister, the Hon'ble Mr. J. H. W. Park (to Ioth July), the Hon'ble Mr. J. M. Sime, the Hon'ble Mr. Song Ong Siang, and the Director of Gardens. (The Committee for the management of the Waterfall Gardens, Penang), the Hon'ble the Resident Councillor, Mr. LawrIE C. Brown, Mr. A. Rogers, Mr. Hastings Rrodes (from ith April), Mr. C. R. SAmuel (to I6th April), and the Director of Gardens.

Thanks are due to these gentlemen for their willing services.

Through the year, Mr. I. H. Burkili, Mr. R. E. Holttum and Mr. J. LenNon were at their respective posts of Director, Assistant Director and Assistant Curator, Parks. Mr. F. Flrppance, Assistant Curator, Waterfall Gardens, Penang, who had been granted leave from gth November, I923, was absent until 29th August, during which time Mi. G. A. Best,-Assistant Curator, Gardens, Singapore, acted for him in Penang, the Singapore duties of Mr. BesT's post being distributed. Mr. M. R. Henderson, lately Systematic Botanist, Museums Department, Federated Malay States, became Curator of the Herbarium upon a temporary footing on ist July. At first he was employed entirely upon an enumeration of the plants of Taiping.

\section{LABOUR.}

Labour was obtained without difficulty. In the year I922, so restless was the coolie that the new engagements in Singapore alone were 2ro: but that restlessness has passed away in such a measure that the new engagements of I924, were only 97.

\section{REVENUE AND EXPENDITURE.}

The revenue made in Singapore was $\$ 3,690.93$ : of this $\$ 1,2$ ro came from the sale of plants; \$2II from recoveries: \$I60 from Miscellaneous sources; and $\$ 2$, IOO from letting out the rubber trees in the Economic Garden. The revenue in Penang by the sale of plants was $\$ 58 \mathrm{I}$.

The Municipalities of Singapore and George Town, Penang, made the usual contributions to the Treasury in return for advice on roadside trees. open spaces, etc. The former paid the cost of music in the Singapore Gardens, and the latter from October Ist, sent its Band to play in the Waterfall Gardens once a week.

\section{BUILDINGS.}

The house for the Assistant Curator, Penang, was completed and in Singapore, quarters were erected for three subordinates.

A quarantine plant-house has been built in each of the two Gardens. Each house contains a fumigation chamber with a capacity of 500 cubic 
feet, and an observation chamber with a floor-area of 12.5 by $7 \cdot 5$ fest, double-doored and enclosed with fine wire gauze.

\section{INVESTIGATIONS AND COLLECTIONS.}

In 1924, a greater amount of field-work was possible than had been in any previous year. In February, the Herbarium Assistant was sent with Dr. F. W. Foxworthy upon an expedition from Kuala Lipis viâ the Sungei Merapoh into Kelantan. In March, the Director, accompanied by Mr. Mohamed Haniff travelled through Kedah, Province Wellesley and Larut collecting economic information. In April, the latter went over part of the ground again to glean further information. In May the Director and Mr. Mohamed HANifF visited successively all the inland parts of the State of Perak upon the same quest; and in September, the latter continued the work by visiting Tapah and Telok Anson. In October, he re-visited Kuala Kangsar. In June, Mr. G. A. Best was sent upon a short collecting trip to Bentong in Pahang. Through November and into December, the Director and Mr. MoHAmed HantFr visited every centre of importance in the State of Pahang: while over the same period a plantcollector was attached to Mr. C. Boden KLoss' expedition to the islands of Sipora and Siberut, off western Sumatra. Two of the Agricultural shows held in the Peninsula were visited by the Director, two by Mr. BEST and two by the Field Assistant, Mr. C. X. Furtado.

The Departmental collections made in this way exceeded 3,000 numbers.

In September, Mr. R. E. Holt tum took a short holiday at Brastagi in Sumatra and gave the collections which he made to the Department. Mrs. Burkitl also visited Brastagi in November, and made collections which she presented to the Department.

Living collections.-Thanks are due to the following for the gift of living plants and seeds:-Messrs B. H. F. BARnARD, Taiping, and A. E. Beavis, Witbank, Transvaal; Captain H. BERKeley, Grik; Dr. G. E. Brooke, Singapore; Messrs. Lawrie C. Brown, Penang, G. B. Deshmukh, Poona, India, H. Dupre, HoaBinh, Tonkin, W. J. C. Frost, London and H. G. Gardner, Penang; Mrs. E. H. Gordon, Singapore; Miss G. Hose, Singapore; the Rev. Father Ichebesta, Kedah; Mrs. Keppel-Garnier, Penang; Dr. A. Kerr, Banghok, Siam; Messrs. J. Le Doux, Kota Tinggi, Mahmud, Alor Star, Coryndon Matthews, Salcombe, Devon and W. E. Rigby, Alor Gajah; Mrs. Shariff, Penang; Dr. G. Vernon, Thursday Island; the late Mr. G. Vereker, Sharpitor, Devon; Mr. W. Way, Kedah; Mrs. Welch, Plainville, Conn., U. S. A.; Messrs. E. W. Williams, Seremban and G. Gordon Wilson, Singapore; the Royal Botanic Gardens, Kew, Calcutta and Peradeniya; the Botanic Gardens, British Honduras; the Departments of Agriculture, Egypt, Federated Malay States, Uganda and United States of America; the Botanic Gardens, Bern, Bangalore, Cambridge and Groningen.

The gift from Mr. MatrHews to the Department was a consignment of seed of Lecythis Ollaria, from which six seedlings have been raised. Mrs. WELCF, a traveller through Singapore, wrote after reaching her home of the pleasure she had had in seeing the Gardens and sent seed of an Amarant which she thought would be an addition: it has done well. Mr. RigBy went to considerable trouble in obtaining seed of Abutilon Listeri for the Gardens; and the plants have flowered. Dr. VERnon's gift was of some beautiful specimens of certain Australian orchids. The Royal Botanic Gardens, Kew, supplied many showy species of garden plants. The Department of Agriculture of the United States supplied plants of some very desirable races of the Avocado pear, which unfortunately did not survive the post. For these gifts and others, very sincere thanks are returned.

The total number of plants received was 993 in Singapore, and 425 in Penang; and of packets of seeds 877 in Singapore, and I69 in Penang. 
It has to be recorded with regret that the second attempt to establish the Milanji Cedar in the Straits Settlements has failed as has also the attempt to establish Pinus Montezumae. The death in Singapore of the dwarfed solitary specimen of Pinus Merkusii has also to be recorded.

The anti-leprosy trees are growing well. On Lawn F Hydnocarpus anthelmintica has attained eight feet; on Lawn $Z$ Gynocardia odorata has attained nine feet; Hydnocarpus castanea on Lawn $F$ is only two feet high: and Taraktogenos Kurzii having made little growth on Lawn F, is only one foot high.

Vitex Volkensii, a new drug-plant, has been put out successfully on Lawn $Z$.

The Marang,-Artocarpus odorata,--has fruited for the first time at five years. Avocado pear-trees raised from Gardens' seed have also fruited both in Singapore and Penang, their age being seven years. The beautiful Bongainvillaea named "Mrs. ButT", an importation of I923, began to flower.

Herbarium.-It has been mentioned above that more field work was possible in 1.924 than in previous years; and that the collections were large. The greater part of these collections consisted of herbarium material; the lesser of living plants. Additional to the herbarium material departmentally obtained, have been a collection of ferns, chiefly Siamese, from Mrs. Malcolm Smith, nearly 500 specimens of Malaysian plants in exchange from the Botanic Gardens, Buitenzorg, $7 \mathrm{r}$ from the Government Botanist, Queensland, a collection from Sarawak, given by Dr. F. W. Foxworthy, and material from Mr. A. Marcan, Bangkok, Dr. A. Kerr, Bangkok, Mr. M. C. Hay, Batu Pahat, Mr. W. N. Sands, Kuala Lumpur, Mr. G. B. Deshmukn, Poona, India, the Rev. Father lchebesta, Kedah and a Japanese visilor, Mr. 7. Teruya.

During the year following herbarium specimens have been sent out:-

to the Royal Botanic Gardens, Kew _.. $\quad \ldots \quad$ I,596 the Botanic Gardens, Buitenzorg $\quad \ldots . \quad \ldots \quad$... 845

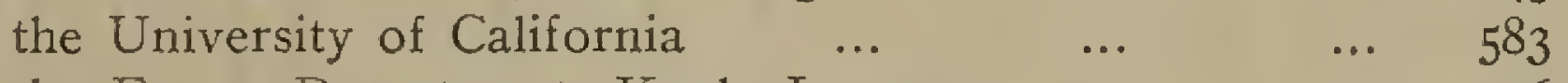
the Forest Department, Kuala Lumpur $\quad \ldots \quad \ldots \quad$... 4 I6 the Government Botanist, Queensland _.. $\quad \ldots \quad 269$ the British Museum of Natural Hirtory, S. Kensington 264 Mr. H. N. Dixon (mosses) $\quad \ldots \quad$... $\quad \ldots \quad 26 \mathrm{I}$ the Royal Botanic Gardens, Calcutta $\quad \ldots \quad$... $\ldots$ 210

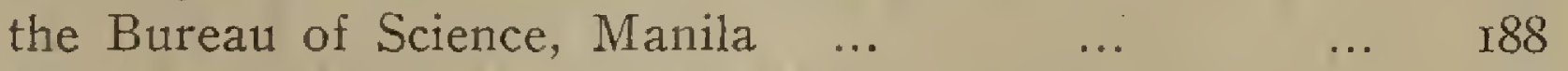
the Arnold Arboretum, Jamaica Plain, Mass _ ... I77

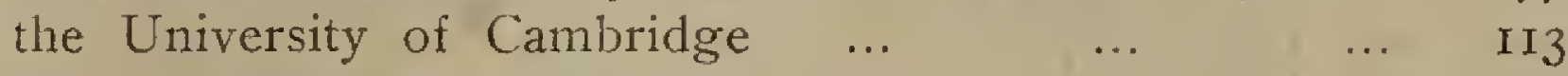

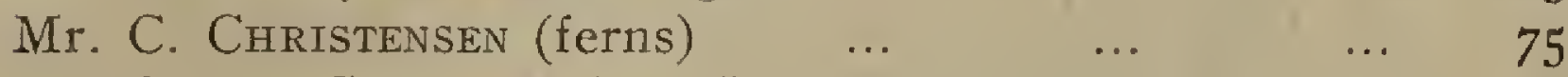
$\begin{array}{llllll}\text { Mr. Curtis G. Lloyd (fungi) } & \ldots & \ldots & \ldots & 65\end{array}$

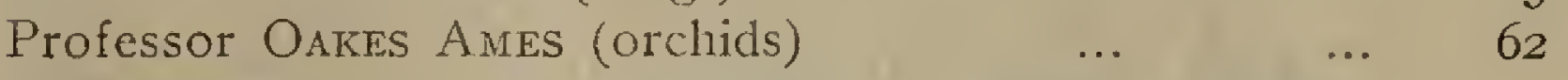
the Department of Agriculture, S. Africa, Division $\begin{array}{llllll}\text { of Botany (fungi) } & \ldots & \ldots & \ldots & \ldots & 53\end{array}$ Mr. J. Groves (Characeae) $\quad \ldots \quad \ldots \quad \ldots \quad \ldots r$

Timber-samples were sent to the Royal Botanic Gardens, Kew, Calcutta, the Botanic Gardens, Buitenzorg, the Arnold Arboretum, the University of Cambridge and the Forest Department at Kuala Lumpur.

The Gardens have received much kindly help in the way of determinations of plants from Mr. H. N. Ridlex, Dr. J. J. Smith, Mr.H. N. Dixon, Mr. Curtis G. Lloyd and Mr.J. Groves. 
Volumes 3 and 4 of Mr. Riduex's Flora of the Malay Peninsula appeared in London during the year. Volume 5 will conclude the work. A study of the ferns of the Peninsula by him lies with the Malayan branch of the Royal Asiatic Society awaiting publication: and an enumeration of the mosses of the Peninsula is promised by $\mathrm{Mr}$. Dixon. The last named has described a series of new Malayan species in the Bulletin of the Torrey Botanical Club. Mr. C. IG. Lloxd continues to publish descriptions and illustrations in his Mycological Notes of the larger fungi, which are sent to him from the Gardens, and during 1924, dealt with $2 \mathrm{r}$.

A re-arrangement of the general herbarium has been commenced upon Mr. RidLEY's Flora: the Director arranged the orders Ranunculaceae to Leguminosae, and Mr. Henderson the orders Nyctaginaceae to Urticaceae. This re-arrangement will be carried throughout; and as it is prosecuted, possible additions to the Flora are brought to Mr. RidLEY's notice for incorporation in his last volume. A parallel re-arrangement of the Gardens herbarium is in progress.

The Gardens herbarium has never been mentioned in the annual reports of the Department; and it is desirable that something should be put on record regarding it. Its purpose is the maintenance of correct names upon the cultivated plants. It took origin in $19 \mathrm{I} 3$, when all sheets bearing specimens of Gardens' origin were withdrawn from the general herbarium into a series of their own. The series was amplified by Mr. G. B. Desir-a MUKH, the first Field-Assistant, who was given the duty of going through the Gardens from end to end to check the names upon the labels, and correct misplacements. It was amplified further by the Record-Keeper and Herbarium Assistant; and from the "Plants-inwards" books all pertinent information was brought into it. Mounting, however, was impossible owing to War conditions, and has remained so until 1924. But the Director has been able from the specimens and the records, to commence a new catalogue of the Gardens upon a proper basis, namely one which will record failures as well as successes in cultivation, a "Hortus Singapurensis"; and he sees no reason against the completion of it by co-operating with the staff aiter his retirement. Its value is obvious.

There is a smaller Gardens herbarium in Penang, made by the employment of Mr. Mohamed Hantff upon checking the labels. This was not possible until he could be relieved in 19r9, of the executive charge; and its use in drawing up a catalogue can only follow after the Singapore catalogue has been prepared.

In 1913 , about 600 herbarium sheets were lent to a professor of Botany in Breslau for study, and in I9I7, about $x, 000$ to the Superintendent of the Royal Botanic Gardens, Calcutta. The majority of the specimens were returned in 1924, and it is hoped to get back the rest at an early date. At the present time very few specimens are out on loan, being the Begoniaceae which are with Professor Irmscher, and a part of the Argostemmas which are with Mr. RIDLEY.

During I924, phyto-geographic and ecological studies have been advanced. Mr. HolTTum's account of the vegetation of the top of Gunong Belumut in Johore is a very interesting piece of work. The Director and Mr. Henderson have in the press an enumeration of the Higher-plants of Taiping with an analysis of their distribution.

Mr. Toн Chun Hock of 7o, Sago Street, Singapore, was so kind as to send to the Gardens a durian fruit wherein was enclosed a second entire fruit, after the fashion of the Navel orange, but completely enclosed. A similar abnormality is mentioned in Mr. Rideey's. Flora, Vol. I, page 262.

Library.-Mr. Furtado completed a card-index to the library. It is arranged under authors: and there are 3,780 entries referring to 4,755 volumes. Of the 3,780 titles, 2,288 are the titles of reprints. This indicates how extremely important to the Department has been the fellowship aniong 
Botanists whereunder other workers have exchanged the results of their work.

Mr. Furtado has also made an inventory of the 1,099 named drawings in the collection, the determination of the others will gradually follow.

\section{BOTANIC GARDENS, SINGAPORE.}

Offences against the by-laws are common: they are rarely important enough to warrant prosecution; and only one summons was taken during the year. Instead offenders are cautioned and a record of the caution made for reference. That they are commoner than is usually supposed may be illustrated by recording that in one twenty-four hours in the month of September, the Director himself dealt with five each under a different by-law. They are certainly more common than they would be if the Gardens did not possess so conspicuously the features of an open place.

Two changes were made in the footpaths; that on the east side of the Palm valley and that on the east side of the Bandstand hill being closed. Two considerable improvements were made in the roadside drainage: one preventing flooding of the lower part of the Palm valiey road, and the other of the Lake-side path. Open cement drains were constructed through the lower nursery. New drain pipes were laid under Lawn L, and at the suggestion and with the help of Dr. P. S. Hunter around the large beds of Cannas an Lawn A.

In March a thick layer of coral was put under the soil of the terraces of the Sun-rockery, the soil enriched and the succulents brought from Kew in 1923 planted. They are doing remarkably well.

\section{Of plants 8,I I w were sent out, and of seed Ior packets.}

Pests.-Syllepta derogata, a moth, was identified as the cause of disfigurement in Hibiscus bushes, the foliage being rolled and eaten. The insect which is a perpetual source of annoyance by eating the leaves of Warsaervicaia coccinca, was found to be a Melolonthid beetle of the genus Apogonia. Phenacoccus icergoides, the Rain-tree coccid, an importation of recent years from Southern India, reached the Gardens through the town; but in the absence of young Rain-trees has not done much damage. Thas been impossible to import its parasites, as the entomologists of southern India do not know them. The entomologists of northern India know of parasites destructive to a closely allied coccid; and Dr. BAtnbrtgge Fletcher was willing to undertake the trouble of isolating them from hyperparasites that he might be able to send them to Singapore: but the Gardens Department is not staffed for the experinenting that the trial would demand, and the kind offer had to be declined.

Mention was made in an earlier Report that galls had been sent to Dr. Docters van Leeuwen, Director of the Botanic Gardens Buitenzorg. On these and on collections of his own made upon a visit, he has reported in a paper published in the Bulletin du Jardin botanique de Buitenzorg, ser. 3 vol. 6.

\section{WATERFALL GARDENS, PENANG.}

The greatest change that has been made in 1924, in the Waterfall Gardens, was brought about by the removal of the Water-lily pond and by the drainage of the hollow where it was. The pond had silted up considerably and was difficult to keep tidy. Cannas are to be planted in its place. The hollow under the Municipal Reservoir was drained likewise.

The rockery in the centre of Plant-house No. 3, has heen re-shaped. Plant-house No. I has been re-roofed with ataps and bertams. Plant-house No. 2 has been covered with wire-netting that creepers may be grown over it. 
The new house, No. Io, was occupied; but it will be some little time before a correct amount shading can be attained, and the best results obtained. The path between it and the Central Bridge was reconstructed in its upper half. In the one-acre block at the Entrance Gate, benches were erected for the work of the two chinese gardeners who are employed now. Upon the rented Municipal block adjacent to it a nursery was laid out.

In October a storm of unsual severity caused a wash-out on the road where the stream of the Swimming bath gully passes under it, and damaged flower beds lower down.

The black monkey Presbytes obscurus has all but killed the last remaining Albizzia moluccana by eating its branch-tips.

Warszewczia coccinea flowered in a very pleasing way.

The gazetted by-laws have been printed and set up at the Gate. Police regulations have been framed to supplement them when the Municipal Band plays in the Gardens.

Two of the upper roads were provisionally opened to motor traffic.

Plants were sent out to the number of 1,869 and packets of seed 23 .

\section{GOVERNMENT HOUSE GROUNDS AND OTHER CHARGES.}

The new avenue along the Edinburgh Road continues to grow satisfactorily: the irregularly spaced remaining trees of Cedrela have been removed except those nearest to Orchard Road, which it is desired to keep.

A detailed report upon roadside trees in the town was supplied to the Municipal Commission, suggesting a programme for application to every road marked as an avenue road upon a map which the Municipality supplied.

The Rain-tree coccid mentioned earlier in this report has done its worst. It has had in consequence of the extensive planting of Rain-trees a few years back an unsually large number of young and vigorous trees on which to feed, and the pruning of them has been in its favour, for there have always been succulent shoots for it.

I. HENRY BURKILL,

Director of Gardens, S. S.

IIth February; 1925 . 


\section{Annual Report of the Director of Gardens for the year 1925.}

\section{COMMITTEES.}

The following gentlemen were members of the Gardens Committee in Singapore at the beginning of the year: Mr. W. Dunman, the Hon'ble Mr. V. Gibbons, Dr. G. H. Macalister, the Hon'ble Mr. Song Ong Siang, the Hon'ble Mr. J. H. W. PARK and Mr. J. M. Sime. In March Mr. Gibrons resigned and his place was taken by Mr. W. A. Stms. The Committee of the Waterfall Gardens, Penang consisted of the Hon'ble Resident Councillor (Mr. A. B. Voules up to May Ioth and afterwards Mr. W. PEEL), the Senior Executive Engineer (Mr. F. T. Kinder), Mr. L. C. Brown and Mr. Hastings Rhodes.

Thanks are due to these gentlemen for their services.

\section{STAFF.}

The Director, Mr. I. H. BurkiLl, was in charge of the Department until February 25th, on which date he left Singapore to take three months' leave prior to retirement from Government Service. Mr. R. E. Holttum, Assistant Director, acted as Director during the rest of the year.

Mr. G. A. Best, Assistant Curator, Singapore Gardens, was absent on leave from April 27th to December Igth; Mr. MoHamed HanifF, Field Assistant, Penang, acted for Mr. Best during this period.

Mr. J. Lennon, Assistant Curator, Parks, Singapore, left for Europe on December - I8th.

Mr. M. R. Henderson performed the duties of Curator of the Herbarium throughout the year on a temporary agreement. His appointment was confirmed in December.

In Penang, Mr. F. Flippance, Assistant Curator, was in charge throughout the year.

\section{LABOUR.}

In Singapore the average number of gardeners and coolies employed, (paid from open votes) was 94. In Penang the average number was 57 . In Singapore the number of new engagements was only 5 I (33 being Indians), as compared with 97 for I924. Rates of pay were unchanged.

The health of the staff was on the whole good. In Penang there were a number of cases of fever, though fewer than in the previous year; this was reflected in a higher percentage of attendances by the daily paid labourcrs. The Health Department continued to treat regularly mosquito breeding places in and near the Waterfall Gardens. 
REVENUE.

Revenue in Singapore was as follows:-

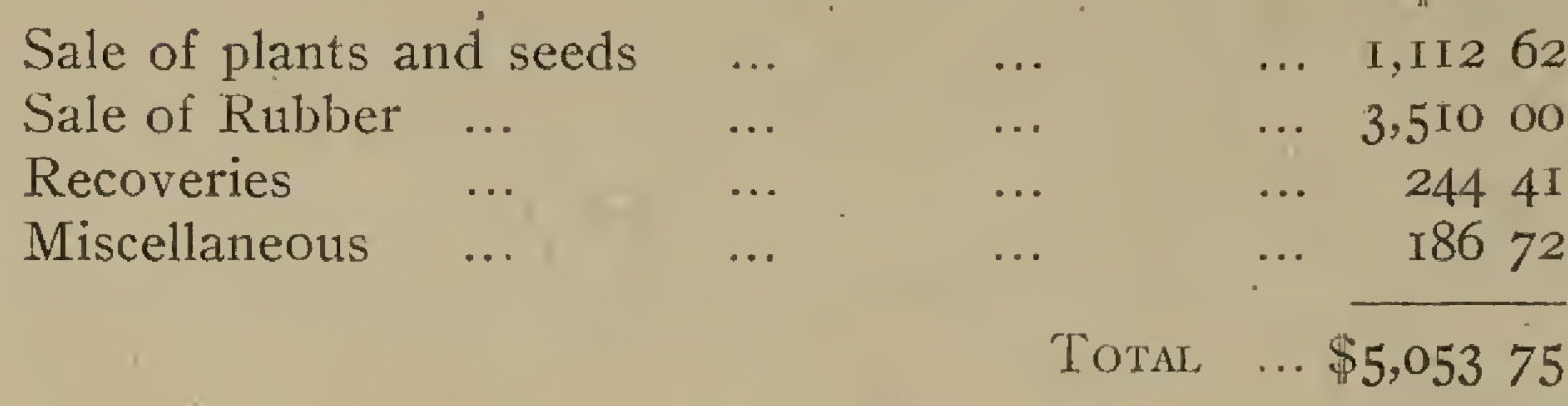

In Penang the revenue from sale of plants and seeds was $\$ 553.24$.

The Economic Gardens in Singapore were taken over by the Raffles College Committee in the latter part of the year, and clearing of building sites was begun. No further revenue from the rubber trees will therefore be obtained.

\section{EXPENDITURE.}

In Singapore there were balances remanning on all votes with the exception of that for coolies. The total balance on all votes at Penang amounted to $\$ 28.66$.

\section{WEATHER.}

In Singapore the weather was normal, except for hery heavy rains at the beginning of January, and for a pronounced dry period in the middle of the year. The rainfall for the month of July was only ${ }^{\circ} 56$ inches. The total rainfall for the year was rather above the average, being I2I*40 inches in the Gardens.

In Penang the total rainfall was I7I' 36 inches, an unusually high figure, largely due to the very heavy rain in October, the total for which month was $45^{\circ} 73$ inches. During six days (October 4 th to 9 th) $32^{\prime} \mathrm{I} 4$ inches of rain were recorded. Though this caused considerable flooding of the stream, little damage was done to the banks owing to various protective works carried out during the year.

\section{BUILDINGS.}

In Singapore three new quarters for subordinate staff were built, adjacent to the Tamil cooly lines. Extensive repairs to the woodwork of the large plant house were carried out by the P. W. D.

In Penang repairs were made to several of the plant houses, both by the Gardens staff and the P.W. D.

\section{COLLECTIONS OF PLANTS.}

The following collections of herbarium specimens and living plants have been made in the Malay Peninsula during the year:

Mohamed HanifF ... In Kuala Kangsar and neighbourhood, January, I4 - I9.

R. E. Holttum

M. R. HENDERSON

R. E. Holttum

F. Flippance

R. E. Holtum

M. R. Henderson

Mohamed Haniff
... Kedah Peak, March 3I to April 2.

Gunong Panti, Johore, April, II - I3.

... Near Batu Gajah, Perak, in April (while on leave).

.. Kuala Trengganu and neighbourhood, May, 6-20.

... Kedah Peak, July, 9- I8.

... Langkawi, August, ry-3I (while on leave).

... Cameron's Highlands, November II to December, 7 .

... Gunong Panti, December, 27th: 
About I,000 numbers were added to the Herbarium accession series and a considerable number of living plants were collected for cultivation. Mr. Henderson's visit to Cameron's Highlands was in conjunction with a survey of the timber trees of that area by the Forest Department. Unfortunately very wet weather prevailed during the expedition and the botanical results were disappointing. Mr. C. X. Furtado, Field Assistant, visited the Agricultural shows at Taiping and Kuala Lumpur, and reported on the Economic Plants exhibited.

\section{HERBARIUM.}

Mr. Hénderson worked regularly in the Herbarium throughout the year. A considerable part of his time was taken up with re-arranging the whole of the collections in accordance with Mr. Riduey's Flora of the Malay Peninsula, the concluding volume of which was published during the year. The re-arrangement of the sheets is now complete, but much yet remains to be done in renewing and re-labelling the covers.

Mr. Henderson also prepared a list of all plants known to occur in the neighbourhood of Kuala Lumpur, which is to be published in the Gardens' Bulletin. For the purpose of obtaining additional information for this list Mr. Henderson visited Kuala Lumpur to consult the Herbaria at the Museum and at the Forest Office.

In addition to the abovementioned work, the bulk of the new collections made during the year were identified and duplicates distributed as follows:-

\begin{tabular}{llllr} 
The Royal Botanic Gardens, Kew & $\ldots$ & $\ldots$ & 523 \\
The Botanic Gardens, Buitenzorg & $\ldots$ & $\ldots$ & 179 \\
The University of California $\ldots$ & $\ldots$ & $\ldots$ & 104 \\
The University of Amoy & $\ldots$ & $\ldots$ & $\ldots$ & 99 \\
The Government Botanist, Brisbane & $\ldots$ & $\ldots$ & 80 \\
The Bureau of Science, Manila & $\ldots$ & $\ldots$ & 89 \\
The University of Cambridge $\ldots$ & $\ldots$ & $\ldots$ & 77 \\
The Smithsonian Institution $\ldots$ & $\ldots$ & $\ldots$ & 56 \\
The Forest Research Officer, Kuala Lumpur & $\ldots$ & 50 \\
The Economic Botanist, Kuala Lumpur & $\ldots$ & $\ldots$ & I28 \\
Mr. H. N. Dixon (mosses for determination) & $\ldots$ & I27 \\
The British Museum & $\ldots$ & $\ldots$ & 36 \\
\multicolumn{2}{l}{} & & & \\
\end{tabular}

Herbarium specimens were received in exchange or as gifts, from:-

The Smithsonian Institution.

The Government Botanist, Brisbane.

The Botanic Gardens, Buitenzorg.

The Arnold Arboretum.

The Forest Research Officer, Kuala Lumpur.

The Economic Botanist, Kuala Lumpur.

Dr. A. KERR, Banglkok.

Thanks are due again to Mr. H. N. Ridley, Mr. H. N. Dixon and Mr. J. Groves for their valuable assistance in the determination of specimens.

Specimens have been lent to other institutions to assist in monographic work, as follows :-

To the Botanic Gardens, Buitenzorg, I 7 I sheets.

To Mr. E. D. Merrill, University of California, 89 sheets. 


\section{GARDENS BULLETIN.}

A large issue of the Gardens Bulletin was published in March, constituting parts 9-I2 of Volume III. This contained an enumeration of the flowering plants known to occur in the neighbourhood of Taiping, prepared by I. H. Burkill and M. R. Henderson, with an introduction analysing the distribution of the species concerned.

\section{PLANTS OUTWARDS AND INWARDS.}

From Singapore Gardens 9,692 plants and 294 packets of seeds were distributed; from the Waterfall Gardens, Penang, 2,420 plants and 105 packets of seeds. The total number of plants received at Singapore was $\mathrm{I}, 646$, and of seeds 120 packets.

Gifts of plants and seeds have been received from the following individuals and institutions, to whom thanks are tendered: Mr. D. R. Boyce, Durban; Dr. A. Kerr, Bangkok; Mr. G. Gordon Wilson; Mr. A. T. Hancock; Mr. B. K. Saheb; the Rev. G. A. Dexrer Allen; Mr. I. H. Burkill; the Directors of the Botanic Gardens at Kew, Buitenzorg, Lal Bagh (Bangalore), Darjeeling, Upsala, Entebbe (Uganda), and Calcutta; the Arnold Arboretum; the United States Department of Agriculture; the Ministry of Agriculture, Cairo; the Botanical and Forestry Department, Hongkong; the Director of Agriculture, Rabatul, New Guinea; the Director of Agriculture, Manila; the Forestry Department, Entebbe, Uganda; the Manchuria Research Society; Messrs. Henry A. Dreer \& Co., Philadelphia.

Mr. BEST took charge of two wardian cases of local plants for the Royal Gardens, Kew, on his voyage home on leave. In exchange various plants were received, brought out by Mr. Best in December. Mr. Lennon also took charge of two cases of plants on his voyage to England, but the weather was unusually severe, and the plants did not survive.

Various new ornamental plants were also purchased in England; most of these were brought out by Mr. Best.

\section{LOSSES.}

In Singapore a tree of Mammea americana at the foot of the lake died, being much overshadowed by a big Adinobotrys. The larger of the two brazil nut trees on lawn $Z$ was blown down in December; it has been replaced by a young plant. Two plants of Rhodoleia Championi received from Hongkong were put out on lawn $\mathrm{Z}$ but unfortunately did not survive.

A young tree of Ficus irregularis near the foot of the lake died, apparently owing to the attacks of a boring caterpillar: another tree of the same species was saved by cutting off two branches, and àfterwards grew vigorously.

Several fine trees of Albizzia moluccana were cut down in the Waterfall Gardens, the trees having been killed by the repeated attacks of the black lotong monkey.

Before the Economic Garden was given up, six gutta percha trees planted in 1903 on the slope above Cluny Road were measured. The tallest measured $\mathrm{I}$ / metres in height, and $\mathrm{x} \cdot \mathrm{I} 6 \mathrm{~m}$. in girth at $2 \mathrm{~m}$. from the ground. The mean height and girth for the six were $14 \mathrm{~m}$. and $92 \mathrm{~m}$, respectively.

\section{PLANTS OF INTEREST.}

Singaporf.-A tree of Amberstia nobilis at Government House produced three seeds, which were germinated sticcessfully. These are the first seeds produced for several years.

The plant of Warscerviczia coccinea at Singapore flowered for the first time in July. It is not growing nearly so well as the plant at Penang, which 
now flowers regularly; it is also continually attacked by beetles, and by Phenococcus iceryoides.

Three plants of Bauhinia Blakcana were received from Hongkong in March. They were planted out on lawn P and have flowered freely. They have also been much eaten by an insect unknown and attacked by Phenococcus.

The new Bongainvillaca, Mrs. ButT, brought from England by $\mathrm{Mr}$. Burkit. in September, 1923, attained a considerable size during the year, and began to flower freely. During the dull wet weather of November and December flowering ceased. This plant should become popular in Singapore, as it has a very vigorous growth and a much finer colour than $B$. glabra, though it has not yet produced such masses of flowers as the latter species.

A plant of a Cereus, apparently C. jomacaru, in the sun rockery, produced two flowers, which opened on the nights of October 24 th and 25 th. This is the first Cereus to flower in the rockery.

Several species of Haworthia and Gastcria flowered occasionally in the sun rockery, and three species of Kalanchoo freely.

Plants of Boea lanato brought from Iangkawi were successfully established in pots.

The plant of Victoria regia in the lake was moved and manured; as a result it made much new growth and has flowered regularly, a new flower about every ten days.

Penang.-A good show of Hydrangeas was maintained throughout the year; plants were taken to Singapore, where they proved equally successful.

Rhododcndron Tcysmannii flowered well in the fern rockery.

\section{PESTS,}

Phenacoccus iceryoides, to which reference was made in the Report for I924, continued to be very troublesome in Singapore, and attacked a large number of species. The following were particularly noted: Vitex pubescens, Podocarpus australis, Bignonia magnifica, Claoxylum indicum, Achras sapota, Phyllanthus sp., Ficus alba, Poinciana regia, Cassia fistula, Plumeria lutea, Bauhinia Blakeana, Erythrina indica, Tectona grandis, and Gardenia florida. On most of these the attack was not severe. Trees of Pithecolobium saman in the town of Singapore continued to be badly infested.

Plants of Aphelandra velutina, introduced in 1923 , were badly attacked by Saissetia hemispharicum Targ., a scale insect which attacks many species of plants in Malaya.

Another scale insect which proved troublesome in the propagating yard was Orthezia insignis Dougl. This attacks various species, but particularly Crossandra undula folia.

For identifications of the above insects I am indebted to the Director of the Imperial Bureau of Entomology and to the Entomologist, Department of Agriculture, Kuala Lumpur.

A Rhizoctonia has caused considerable trouble. It was first noticed attacking Jerusalem artichokes in the Economic Garden a few years ago. Thence it travelled somehow into the upper garden, where it was first noticer in 1924. It killed plants of Oxalis in the sun rockery, and also Notonia grandiflora. On the bandstand hill it found its way into a bed and killed plants of Crotalaria sp., and perennial asters. It also attacked Gloriosa superba and two species of Fittonia. On account of its small resistant sclerotia this fungus is very easily distributed, and is very difficult to control. Heat appears to be the only effective method of destroying it. 


\section{WORK IN THE GARDENS.}

Singapore.-Various improvements were made along the borders of the Gardens. Along Cluny Road a number of dangerous trees were removed, and some new trees planted to fill up the gap near Tyersal Road corner; the shrubby borders in the southern part of Cluny Road were cleared of many unnecessary plants, and the dense growth of weeds by the propagating yard replaced by hedges of Hibiscus and Bougainvillea. The thicket along the border of Tyersal Road round Lawn $Z$ was also cleared, a hedge planted, and a row of Mesua ferrea planted inside the hedge.

The sun rockery was improved by banking up the lower part, and covering it with coral in which pockets of earth were made. In this way accommodation was provided for a large number of small plants. The Kalanchoes and Crassulas made much improved growth under these conditions.

The appearance of the lake was improved by manuring the Nymphæas, which responded remarkably in their flowering. New Nymphæas raised from seeds obtained from H. A. Dreer \& Co., were also planted. The dell at the head of the lake and the path leading to it were planted with balsams of various colours, and additional tree ferns were planted. An Albizzia by the lake had to be removed, and was replaced by a Lagerstromia.

Several new climbers were planted in the large plant house, to give more shade, and made good growth, except Argyrcia campanulata. This species had proved very successful at Penang, but perhaps the iron supports of the Singapore plant house did not suit it.

The base of the fine tree of Terminalia subspathulata at the top of Maranta Avenue was cleared of the shrubs which had grown up about it, and the appearance of the corner much improved,

Ficus irregularis was planted to take the place of the avenue of Arenga saccharifera above the Tyersal-gate; the Arengas will have to be removed in a few year's time.

Penang.-In addition to the usual routine work a number of improvements were made in various parts of the gardens. Part of the rockery on lawn $\mathrm{E}$ was rebuilt and the whole replanted. A new retaining wall was built by the fern rockery to prevent damage when the stream is in flood; this proved very satisfactory, being thoroughly tested by the floods in October. Other repairs were also made to the stream bank.

New planting of ornamental plants was carried out in various places, with the object of giving additional colour.

\section{GOVERNMENT HOUSE DOMAIN AND OTHER OUTSIDE CHARGES}

Singapore.-The usual routine work at Government House was continued, and various small improvements were carried out.

At the request of the Singapore branch of the Ex-Services Association the Government agreed to maintain permanently a. wreath on the Cenotaph. After trial, a wreath of living plants was prepared which proved satisfactory. The Committee of the Cricket Club kindly consented to be responsible for the necessary daily watering of the wreath. This' work was carried out by the Assistant Curator, Parks.

During the year about $\mathrm{I}, 800$ trees were provided for the Admiralty oil fuel stations; the planting of these was supervised by the Assistant Curator, Parks. Trees and shrubs were also provided for the Geylang English School, and for Government building sites at Ridley Park, Mount Rosie, and in Scott's Road.

The Assistant Curator, Parks made regular inspections of roadside trees in Singapore, and gave advice with regard to new planting, and to the develop. ment of the new roadside tree nursery. 
Penang.-The control of the Gardens at Bel Retiro and Strawberry Hill was taken over from the Public Works Department Overseer on March 9th. A large number of alterations have been made at Bel Retiro, both re-arrangements of beds and re-planting, and a considerable improvement effected. The removal of the vegetable garden to a site just below "Belle Vue" was begun. Development on Strawberry Hill and the terraces below it was continued, new beds prepared and necessary grassing carried out. A feature of these hill gardens, throughout the year was the excellance of the pot plants, particularly dahlias. Among the plants in bloom during the latter part of the year the following may be mentioned: Hydrangeas, Cornflowers, Nasturtiums, Heliotropium (exceptionally good):Hollyhocks and pansies. Wallflower plants were growing wèll and should flower later.

The usual inspections of roadside trees and Municipal Gardens were made by the Assistant Curator, and reports submitted where necessary.

R. E. HOLTTUM, Acting Director of Gardens, S. S.

24 th April, 1926. 



\section{Annual Report of the Director of Gardens for the year 1926}

\section{COMMITTEES}

The following gentlemen, to whom thanks are due for their services, were members of the Gardens Committees.

Singapore-

The Hon'ble Mr. J. H. W. Park, the Hon'ble Mr. Song Ong Siang, W. Dunman, Esq., Dr. G. H. MacAlister, W: A. Sims, Esq., (to May), J. M. Sime, Esq., R. W. Hughes, Eso., (from May).

\section{Penang-}

The Hon'ble the Resident Councillor (Mr. W. Peet to 8th May, and afterwards Mr. R. ScotT), the Senior Executive Engineer (Mr. F. T. Krnder to 28th March, Mr. G. Holden from 29th March to I 7 th November, and afterwards Mr. F. T. Kinder), L. C. Brown, EsQ. Hastings. Rhodes, Eso., (to March, 24th), B. Nunn, EsQ., (March 25th to September 25th).

\section{STAFF}

The Director, Mr. R. E. Holtтum, was in charge of the Department until November I8th, when he left for Europe on leave.

Mr. M. R. Henderson, Curator of the Herbarium, was absent on - furlough from February 6th to October I8th, and acted as Director from November igth.

Mr. G. A. Best, Asst. Curator, Singapore Gardens was in Singapore throughout the year.

Mr- J. Lenvon, Assistant Curator, Parks, Singapore, was absent on furlough up to September 25th.

Mr. F. Flippance, Assistant Curator, Penang, was in executive charge of the Waterfall Gardens, Penang, throughont the year.

Mr. Mohamed Hantff, Field Assistant Penang retired on June zoth after completing 36 years very valuable service. He first entered the service of the Gardens Department in I890, and has served continuously since that date being in executive charge of the Waterfall Gardens, Penang, during the years I9Io to I92I. Mr. HANIFF has during this long service acquired an extensive knowledge of the Malayan flora and has contributed largely to the collections of Botanical material in the Peninsula, while he has done a great deal of valuable horticultural work. Abdul Kadir bin Elias succeeds him.

\section{LABOUR}

In Singapore the maximum number of gardeners and coolies employed at any one time was 93 .

In Penang the average strength of the labour force was a little over 58 , which is slightly higher than the previous year. Rates of pay were unchanged. 


\section{REVENUE}

Revenue in Singapore was as follows:-

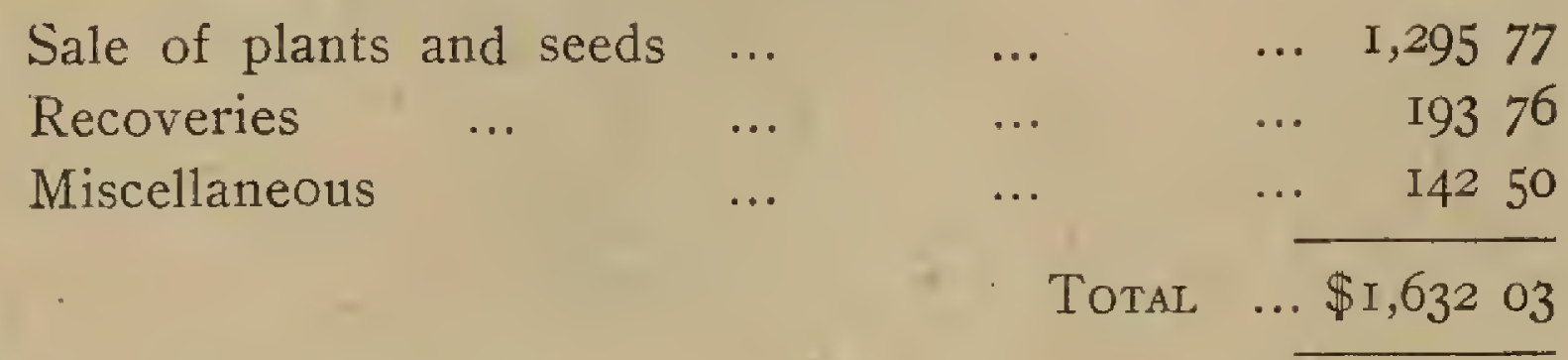

In Penang the Revenue from the Sale of plants was $\$ 826.79$.

\section{EXPENDITURE}

There were balances remaining on all votes in Singapore with the exception of that for the Library. The total balance on all votes in Penang amounted to $\$ 153.73$.

\section{COLLECTIONS AND INVESTIGATIONS}

Very little collecting was done during the year owing to the shortage of staff consequent on the absence on leave of Mr. Henderson and Mr. Lennon.

Mr. Holttum collected on Gunong Panti, Johore, in February, on Penang Hill at various times, and in Java, in August.

Mr. Holttum visited Buitenzorg for a fortnight in August, and was very kindly received by the Director and the staff, and acquired much valuable information concerning organisation of Gardens and Herbarium. Some time was spent working in the Herbarium on the comparison of Malay Peninsula and Netherlands East Indies collections, and a visit was paid to the mountain garden of Tjibodas.

\section{HERBARIUMM}

Towards the end of the year the herbarium of the Federated Malay States Museums was handed over to the Botanic Gardens on loan, and the work of re-arranging and incorporating was begun. Each sheet bears a distinctive label, so that the two herbaria can readily be separated.

While on leave in England, Mr. Henderson spent a short time in the Herbarium of the Royal Botanic Gardens Kew, working on material collected on Cameron's Highlands.

Specimens were distributed as follows:-

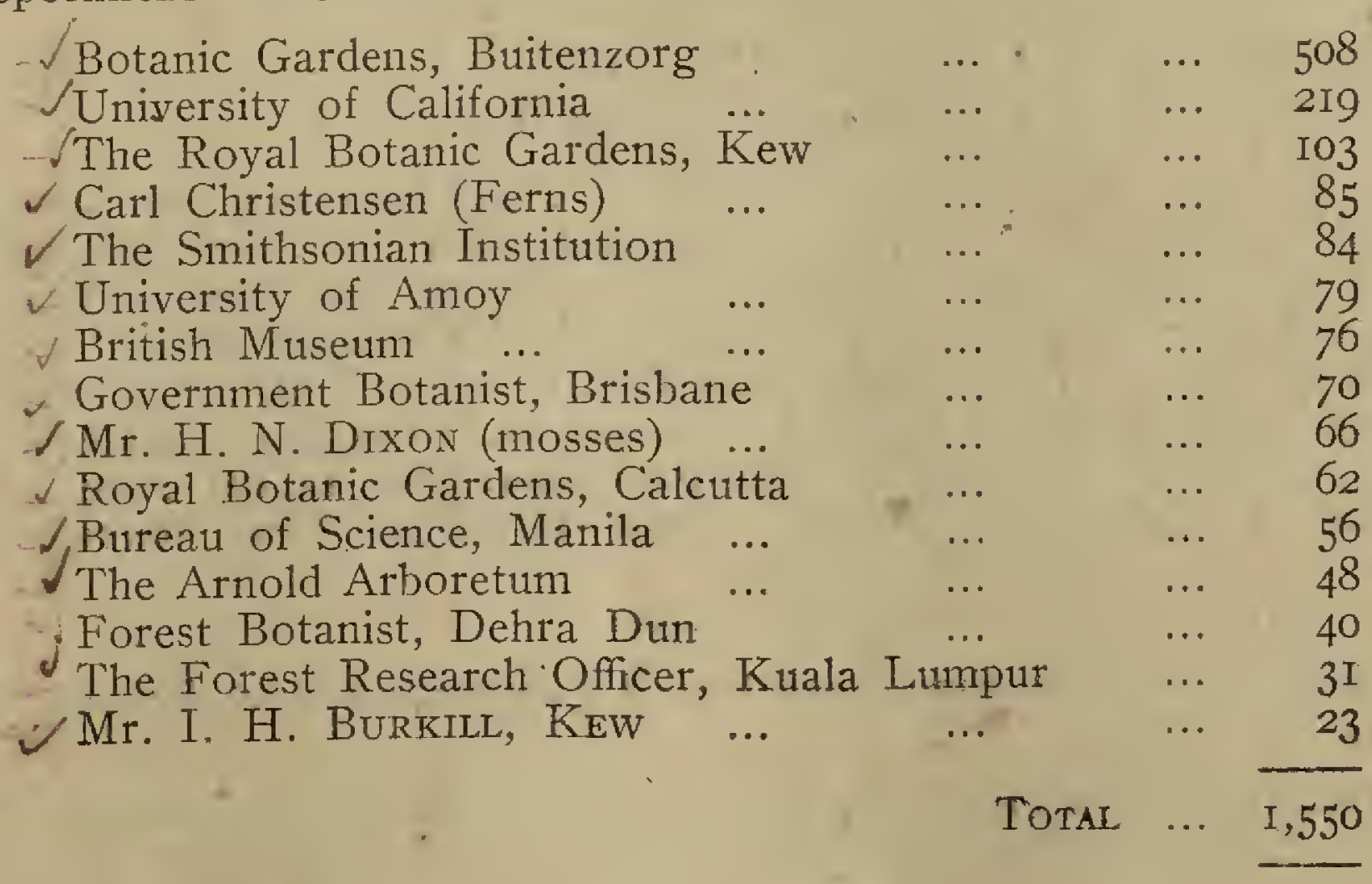


Hand timber specimens were distributed as follows:-

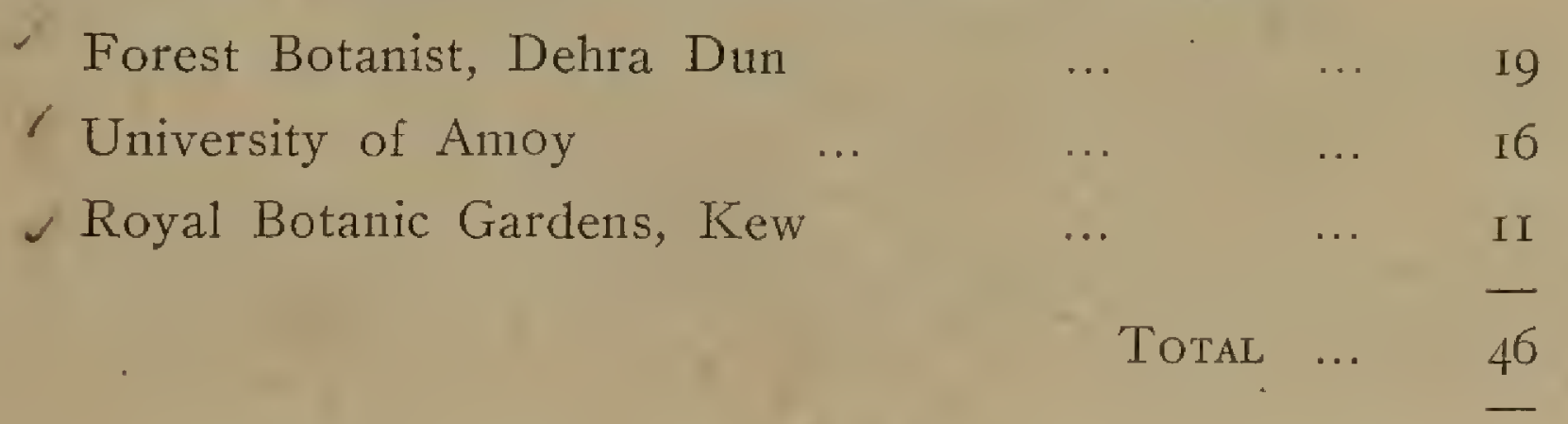

Specimens have been lent for study to other persons and institutions as follows:-

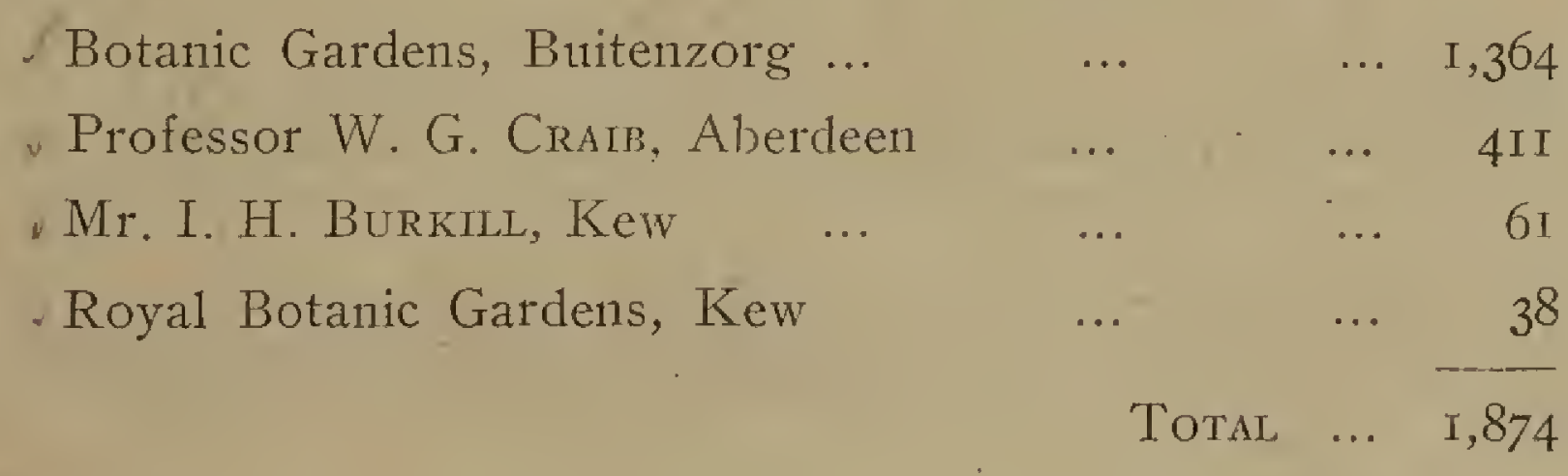

\section{PUBLICATIONS}

Vol. IV, Part I of the Gardens Bulletin was published in July, consisting of a list, prepared by Mr. H. N.vDixon, M.A., F.L.S. of the mosses known up to date from the Malay Peninsula. Very hearty thanks are due to Mr. Dixon for this work and for the identification of specimens submitted to him from time to time. Some 340 species are cited in the list, a large proportion of which have been sent to Mr. Dixon during the past four years.

Vol. IV, Parts II and III, consisting of miscellaneous papers, was sent to the press in November.

Mr. H. N.'RrdLey, C.M.G., F.R.S., published a list with descriptions of the ferns of the Malay Peninsula in the Journal of the Malayan Branch of the Royal Asiatic Society, Vol. IV, Part I in August.

\section{PLANTS OUTWARDS AND INWARDS}

Eight thousand two hundred and forty-nine plants and 48 packets of seeds were distributed from the Singapore Gardens during the year, and from the Waterfall Gardens, Penang, I,948 plants and 203 packets of seeds.

Two thousand one hundred and fifteen plants were received at Singapore and 80 packets of seeds.

The following donors of gifts of plants and seeds are thanked:-

W. B. Way. EsQ., District/Officer, Upper Perak; Mr. Mohamed HanifF; the Curator, Lloyd Botanic Gardens, Darjeeling, India; Mr. B. K. SAHEB; Vinke Dujardin, Scheepsdade, Bruges; Mrs. H. Marriott; Ahmad bin Hassan: Botanic Gardens, Eala, Belgian Congo; Mrs. Gougr, J Kajang; Mr. I. vH. Burkill; ${ }^{2}$ The Director, Royal Botanic Gardens, Kew; Mr. G. A. Le -Doux; Mr. Wrigiti; The Director, Botanic Gardens, Buitenzorg; Dr. Gilbert Brooke; Mr. G. Gordon Wilson; The Royal Botanic Gardens 2 Peradeniya; Mr. P. Feddersen; Dr. Crahay, Congo Belge; Mr`s. Obbott; Mr. H. H. Chung, University of Amoy.

Mr. Lennon brought out two wardian cases of plants in exchange from Kew in September, and two were sent to Kew in the first half of the year, Mr. M. JAMIESON kindly undertaking to look after them on the voyage. 


\section{BOTANIC GARDENS, SINGAPORE}

The abnormally dry spell in the beginning of the year induced profuse flowering in such shrubs as Petraea spp., and in orchids.

\section{Additions-}

Aralia Kerchoveana, from Melanesia and Aralia leptophylla, from Oceania were planted on Lawn O. Clerodendron fallax, a Javanese species, was also planted on Lawn $\mathrm{O}$.

Platycloden grandiflorum, a Chinese and Japanese herb of the family Campanulaceae, has done well.

Two new Bougainvillaeas, B. MaUd Cuttleburge and B. Thomsoni were planted on Lawn B.

The Podocarpus cupressinus at the foot of the Lake was removed. The old Waringin at the office entrance was partly blown down in December, and the opportunity was taken to remove it entirely.

Plants were supplied during the year to the Agricultural Department Malacca, to the P. W. D. Singapore, and to Dr. FaIRChild, for the U. S. A. Department of Agriculture.

As a result of Mr. Holtrum's visit to Buitenzorg, various new plans have been made for the organisation of the Gardens. Among them, a beginning has been made with a system for a more easily accessible record of the existing woody plants in the Gardens and of the new introductions of all kinds.

A card index, alphabetically arranged, is being prepared, to include in the first place these trees and shrubs planted in the Gardens which have already received numbers. This index refers to maps of the various sections of the Gardens, which have carefully been made by Ammad bin Hassan; the Record Keeper, to show the position of every tree so that by the index it is possible quickly to locate any required species; this is most desirable in a garden such as this, in which there has been no sys'ematic planting. The index and maps have also to be checked with the specimens preserved in the Gardens Herbarium. All data known concerning the origin and history of the trees are also entered on the index cards.

As regards the older trees, this work is well advanced, but naturally much checking remains to be done. For new introductions in the past, a record has been made in the plants-inwards book only. This is a cumbrous article, and it is not easy for the Assistant Curator to check the plants in the yard from it, or to enter records of their subsequent history. Accordingly, a card is now prepared for each new introduction. This card is sent with the plants or seeds to the propagating yard, and is put into a temporary alphabetical index there. All pots are numbered and named with permanent embossed labels, as formerly. When a plant is to be planted out into the Garden, its card is put into the General alphabetical catalogue, with a note of the date, and its exact locality. If the plant dies, the card is also preserved, and notes on its behaviour are entered. Periodically the Assistant Curator goes through all the cards in the yard catalogue, checking the plants and making notes where desirable.

By this system, along with the plants-inwards book and the Gardens Herbarium, it is hoped to keep a more accurate record of new introductions which in the past have too often been lost sight of. It is a beginning, and will need mich accurate and patient work to maintain, but we hope to carry it through. It will greatly add to the value of the Gardens, and will be of considerable assistance to the staff in the location of plants needed by visitors or correspondents. It will also preserve definite record of the behaviour of plants difficult to cultivate, or unsuited to this climate, which do not survive, and so be a guide to future introductions.

The aim is finally to extend this index to all species cultivated in the Gardens, but to achieve this will take several years. 


\section{WATERFALL GARDENS, PENANG}

A number of improvements were carried out in addition to the usual routine work. A small bridge was built over the small side stream at the Lily Pond to conform to the larger bridge over the Pond outlet. The stream bank in the plant yard and in other places was repaired, and a cement tank built in the Pot-plant nursery. A large clump of Wormia suffruticosa on Lawn E, which had been allowed to grow unchecked for several years was removed, thus opening up a view of Lawn E.

\section{GOVERNMENT HOUSE DOMAIN AND OTHER OUTSIDE CHARGES}

\section{Singapore-}

Mr. J. Lennon, Assistant Curator, Parks, was on leave until September 25th and work at Government House was supervised by Mr. G. A. Best. Little other outside work was done until October. Planting of trees and shrubs was done at the Labour Office and at Raffles Museum, and the Assistant Curator, Parks, continued to inspect roadside trees and to give advice with regard to felling and planting.

\section{Penang-}

Work on the Gardens at Bel Retiro and Strawberry Hill has been successfully continued, and the vegetable garden enlarged. Lack of water and manure is a serious problem in connection with these gardens. An unfailing supply of excellent pot-plants has been maintained throughout the year, and welcome additions were Lilies from Japan, an Aster (Michaelmas Daisy) obtained from Buitenzorg, Geraniums, Fuchsias, Buddleia, Dahlia imperialis from Fraser Hill, and Heliotropes raised from Sutton's seeds.

The usual inspections of roadside trees were carried out by the Assistant Curator, and reports submitted when necessary.

M. R. HENDERSON, Acting Director of Gardens, S. S.

28th March, 1927. [No. 2591/27.] 



\section{Annual Report of the Director of Gardens, Straits Settlements for the year 1927}

\section{COMMITTEES}

Thanks are due to the following gentlemen for their services as members of the Gardens Committees at Singapore and Penang.

I. Singapore.-

The Hon'ble Mr. Song Ong Siang, Mr. W. Dunmax, Mr. J. M. Sime, Dr. G. H. MacAlister, Mr. R. W. Hughes, Professor K. B. Williamson.

2. Pcnang.-

The Hon'ble Resident Councillor (Mr. R. ScotT), the Senior Executive Engineer (Mr. F. T. Kinder), Mr. L. C. Brown, Mr. C. R. Samuel.

\section{STAFF}

Mr. M. R. Henderson, Curator of the Herbarium, acted as Director until August 13th, upon which date the Director resumed his duties after leave in England. 8 th.

Mr. C. X. Furtado, Assistant Botanist, was absent on leave until May,

Throughout the year Mr. G. A. BEST had charge of horticultural work in the Singapore Gardens, Mr. F. Flippance of work in the Waterfall Gardens, Penang and Mr. J. Lennon of work in Government House Domain, Singapore, and of other outside charges.

Mr. Abdul Kadir bre Elias was confirmed in the post of Field Assistant Penang, from July Ist, I927.

\section{LABOUR}

In Singapore the average number of gardeners and coolies employed was 90 ; in Penang 62. Rates of pay were unchanged.

\section{REVENUE}

Revenue from the sale of plants and seeds' was as follows:-

$\begin{array}{lllllll} & & & & \$ & c . \\ \text { Singapore } & \ldots & \ldots & \ldots & \ldots & \mathrm{I}, 835 & 85 \\ \text { Penang } & \ldots & \ldots & \ldots & \ldots & \mathrm{I}, 002 & 55\end{array}$

\section{PLANT COLLECTION}

Mr. M. R. Henderson spent the period between April 24th and May 29th on the Islands of Aor, Dayang and Tioman, accompanied by Mr. N. SMEDLEY of the Raffles Museum. For the first part of the expedition the Fisheries Department kindly lent their steam launch the "Shark". The collections proved extremely interesting, all the more so because they were the first to be made at an altitude of above $\mathrm{I}, 000$ feet on Pulau Tioman. The highest 
point of the Island, G. Kajang ( 3,383 feet) was reached and collected upon. Several plants new to science and several not before recorded as occurring in the Malay Peninsula were obtained. Among the former are a fine Begonia (B. tiomancnsis Ridl.) a Cologyne (C. tiomanensis Hend.) and a beautiful white flowered Kopsia ( $K$. alba Ridl.).

From October Ioth to November 5 th Mr. Henderson made a further expedition, to the Pahang-Kelantan boundary, for the purpose of collecting on the limestone hills there. Collecting was done near Chigar Perah, Pahang, and Goa Ninik, Kelantan, a number of plants being sent alive to Singapore for cultivation: amon: these, some interesting Balsams hare been siccessfully established. Thanks are due to the Railway Construction Department at Chigar Perah for providing transport, and accommodation in their rest house and halting bungalows.

During July Mr. Henderson visited Gunong Lanoh, near Batu Gajah, Perak, and obtained living plants of the rare Buxus malayanus Ridl. and Jasminum cordatum. Rid1. for cultivation in Singapore.

During July, August and September Mr. C. Boden KLoss, Director of Musuems, S. S. and F. M. S., undertook an expedition to Sandakan, British North Borneo, Banguey, Balambangan and Mallewallé Islands. Mr. KLoss kindly took with him a plant collector from the Singapore Gardens and supervised his work. The resulting collections of Angiosperms have been sent to Dr. E. D. Merrill for determination; the ferns to Mr. C. Christensen, and the mosses to Mr. H. N. Dixon. On December 27 th the Director ascended,Gunong Panti, Johore, and collected further material of some of the peculiar plants which are found on the rocks near the top of that mountain. Ophioglessum simplex. Ridi., a most remarkable fern, was also collected for the first time in the Malay Peninsula.

\section{HERBARIUM WORK AND OTHER INVESTIGATIONS}

While on leave in England, the Director worked in Kew Herbarium during February and March, mainly on the ferns of the Malay Peninsula.

At Singapore $\mathrm{Mr}^{*}$. Henderson carried on the usual herbarium routine work, and in addition the following:-

(a) Naming of large collections for the Forest Department;

(b) Naming a small collection from Gunong Benom, Pahang; made by a collector of the Federated Malay States Museums, and preparation of a paper thereon, published in the Federated Malay States Museums Journal Volume XIII, part 4;

(c) Preparation of a paper on plants from Cameron's Highlands, Pahang, published in the Journal of the Malayan Branch, Royal Asiatic Society, Volume 5, part 2;

(d) Completion of a paper on the flowering plants of the Kuala Lumpur district, for publication in the Gardens Bulletin;

(e) Preparation of two small papers in the Gardens Bulletin, Volume IV, Numbers $2-3$;

(f) Determining collections from P. Aor and P. Tioman and preparation of a paper on them.

After his return from leave, the Director started a series of weelly observations on the flowering and leaf changes of about 80 trees and shrubs, both local and exotic, in the Gardens. It is hoped that after a period of years these observations may be of considerable interest not only as a record of the behaviour of a number of individual plants but also as a means of throwing some light on the question of the effect of our slight and irregular climatic changes on the periodic phenomena of plant life. The climate of Singapore is more uniform in character than that of any locality in the tropics where comparable series of observations have been carried out. 
Duplicate herbarium specimens have been despatched as exchanges to the following :-

Botanic Gardens, Buitenzorg

Dr. E. D. Merrill ... …

$\cdots \quad+\cdots \quad 44 \mathrm{I}$

$\cdots \quad \cdots \quad 335$

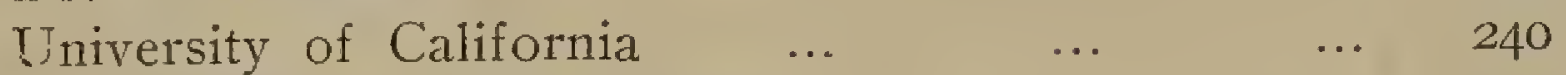

Royal Botanic Gardens, Kew ... $\quad \ldots \quad \ldots 207$

Government Botanist, Brisbane $\quad \ldots \quad \ldots 92$

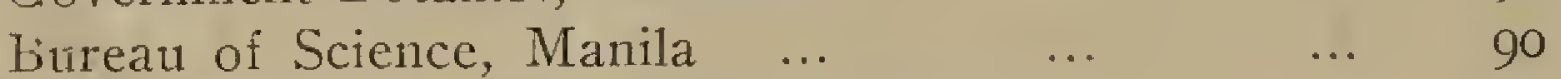

Forest Research Officer, Kuala Lumpur ... $\quad$... 7 7I

$\begin{array}{lllll}\text { University of Amoy } & \ldots & \ldots & \ldots & 6 \mathrm{I}\end{array}$

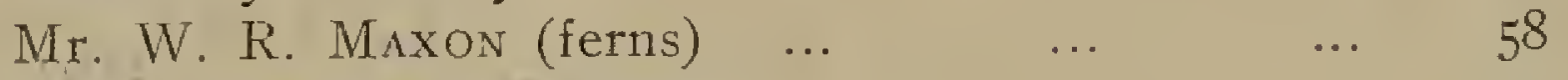

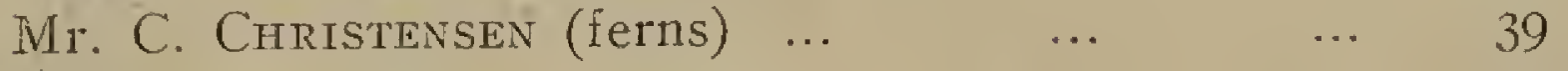

$\begin{array}{llllll}\text { University of Cambridge } & \ldots & \ldots & \ldots & 53\end{array}$

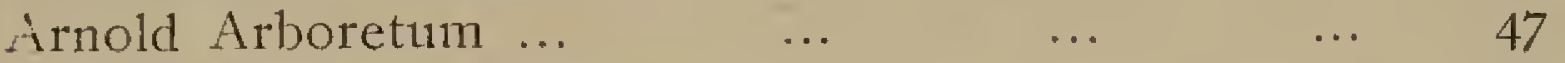

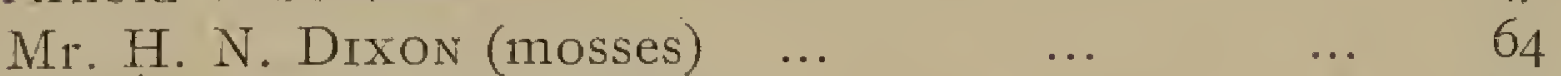

Professor S. R. Bose (fungi) ... $\quad \ldots . \quad \ldots \quad$ I3 8

Dr. Einar du Rietz (lichens) ... $\quad \ldots \quad \ldots 97$

Hand timber specimens were distributed as follows:-

$\begin{array}{llllll}\text { Arnold Arboretum ... } & \ldots & \ldots & \ldots & 22\end{array}$

Forest Research Officer, Kuala Lumpur ... $\quad \ldots .8$

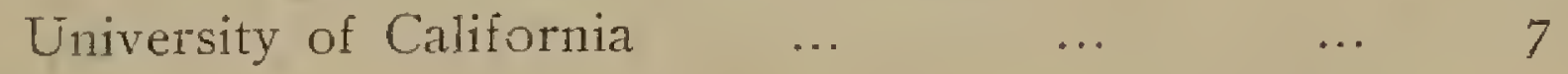

Herbarium specimens have been lent for study to other persons and institutions as follows:-

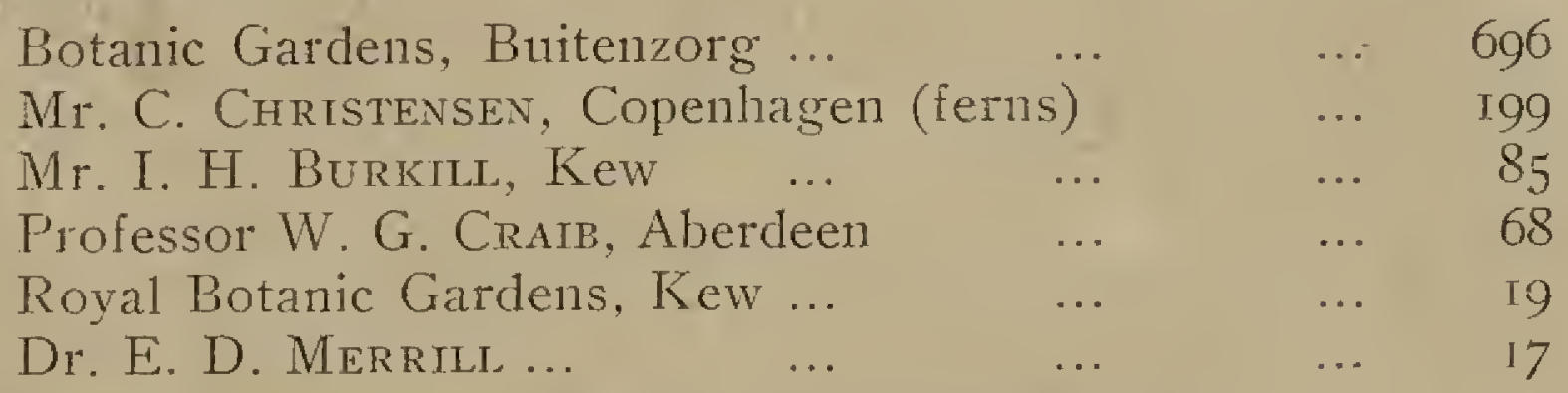

Specimens have been received in exchange from:-

The Botanic Gardens, Buitenzorg;

The Smithsonian Institution, Washington;

The British Museum (Natural History);

The Forest Research Officer, Kuala Lumpur.

\section{PUBLICATIONS}

The illustrated Guide to the Singapore Gardens, prepared by the late Director, Mr. I. H. BurkILL, and printed in England, arrived in the Colony in Apri1. It consists of 60 pages of descriptive matter, including 40 illustrations, half of which occupy a full page.

In March, I927 Volume IV. 2--3 of the Gardens Bulletin was published. This contained a number of short articles contributed by Messrs. Burkilu, Holttum. Henderson and Furtado, and included the description of ten new species of plants from the Malay Peninsula. Volume IV $4-5$ appeared in August, 1927, and consisted entirely of paper by Mr. I. H. BurkiLL on the Botanical Collectors, Collections and collecting places in the Malay Peninsula. In this publication Mr. BurkILl gives an exhaustive summary of the botanical txploration of the Peninsula up to the present time; he indicates also very clearly how much further exploration and collecting are necessary before we can fairly be said to have a satisfactory knowledge of the local flora and its distribution.

A further large issue of the Bulletin, containing a list prepared by Mr. Hexderson of the plants occurring in the neighbourliood of Kuala I.umpur, with notes of their habit and distribution, has been completed and is in the press. 


\section{PLANTS INWARDS AND OUTWARDS.}

The following plants and seeds were sold, sent as exchanges or otherwise distributed:-

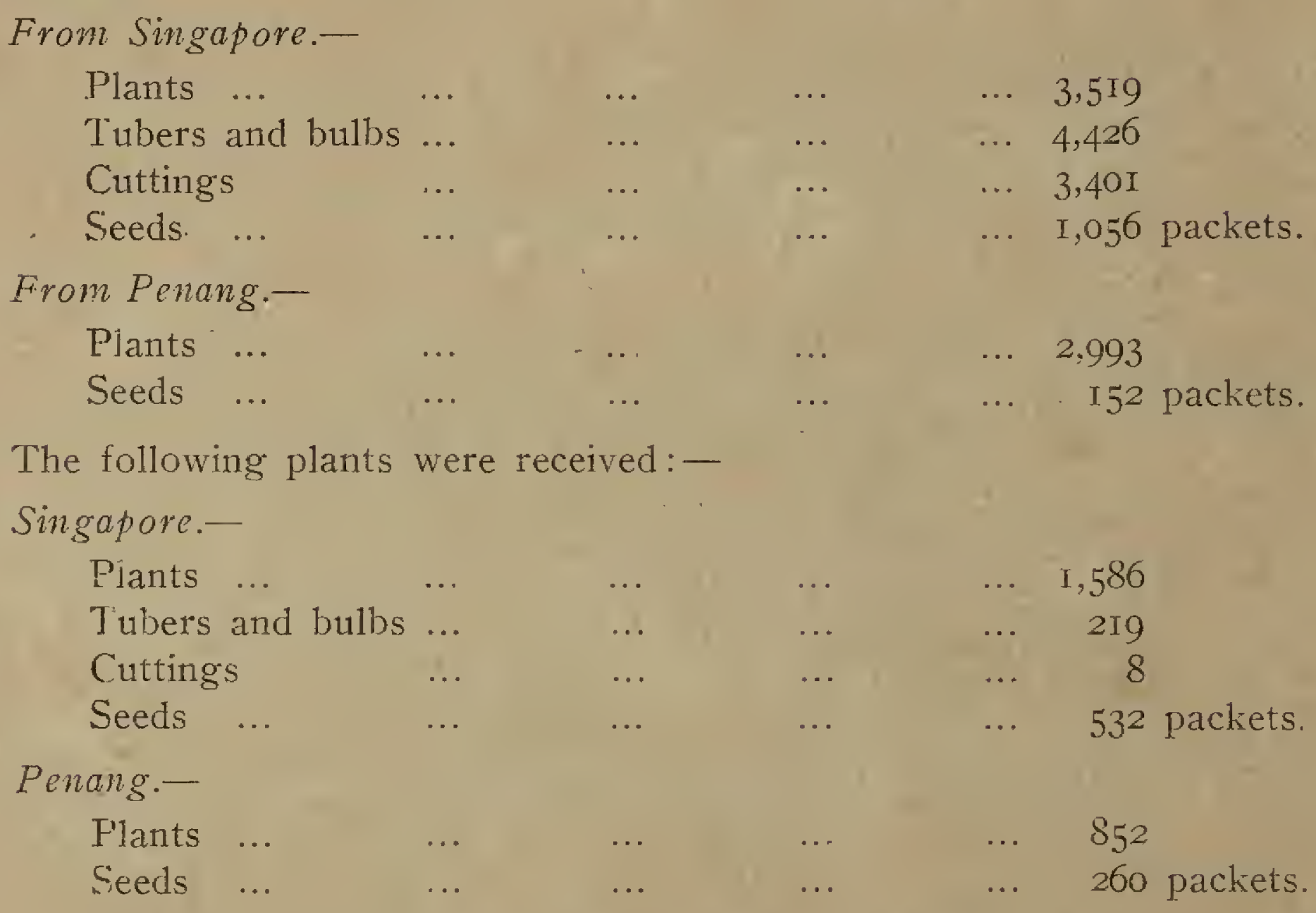

The Director brought out two cases of plants from the Royal Gardens, Kew, when returning from leave in July, in continuation of exchange of plants with Kew. Thanks are due to the following for the gift of plants or seeds :-

Mrs. Starr (orchids from Burma and Siam), Mr. C. E. Carr, Mr. J. N. Milsum, Phya Pradibadha Bhubal (Consul-General for Siam). Mr. C. E. Lane Poole, Professor Juan Balme (Mexico), Dr. G. E. Brooke, Mr. B. K. Saheb; Messrs. Vincke, Dujardin (Bruges), and to the following institutions:-

The Botanic Gardens at Kew, Eala (Belgian Congo), Bombay, and Darjeeling; the Department of Agriculture Jamaica; the U. S. Department of Agriculture: the Director of Agriculture, Rabaul, New Guinea; the Director, Horticultural Section, Giza, Egypt.

\section{BOTANIC GARDENS, SINGAPORE}

The weather was unusually wet during the earlier part of the year (January I8.32 ins., February 10.97 ins., March 16.80 ins.) resulting in a general lack of flowering of trees; June, July and August were rather dry, but not excessively so. There was a fairly general flowering from September onwards, followed by a good fruit crop about the close of the year.

More than one hundred woody plants and palms were planted out in the Gardens ciuring the year, many being recent introductions. Most of these are growing well, but several species of Cocos are not flourishing and some have died. Among the plants newly put out are Scheelia insignis, Scheclia regia, Actinophlous angustifolia, A. promorsus, Musa discolor, M. rosca, Lecythis ollaria, Lecythis pisonia, Copaifera officinalis, Albizzia calcnsis, Acacra catechu, Chlororylon Swietenia, Bassia Hollnungi, Tetrapleura Thonningii, Pachira aquatica, Pavetta abyssinica, M(esopsis berchemoides, Clerodendron ugandense.

Standard plants of Hibiscus raised from hybrid seed obtained from Honolulu were planted out along the main gate Road, and have begun to flower. It is intended to add to these and form a representative Hibiscus collection in the area. 
In the Sun Rockery granite chips have been mixed with the soil in order to improve drainage, and a number of new plants were put out. Haworthias, Gasterias and most Crassulacex continued to grow poorly and it is evident that the climate is tunsuitable for them. A number of species of Opuntia and Cereus continued good growth, but most of them produced no flowers. Bozvenia spectabilis produced a new shoot and continued to grow well; Stangeria paradoxa was also planted out in the rockery.

During the wet weather towards the close of the year some attention was given to the improvement of lawns, many of which had got into bad condition; some were top-dressed with manure, and a portion of lawn M. replanted entirely with Cynodon, with good results.

The front portion of the large plant house roof was entirely taken down, and an iron framework roofed with laths erected in its place, by the Public Works Department. The shelter near the lake was also re-roofed and glass houses in the potting yard repaired and painted.

Some progress was made with the card index of plants in cultivation, and all new additions have been included in the list. This work is being undertaken jointly by the Assistant Botanist and the Record Keeper; the former is also systematically working through and adding to the Gardens Herbarium of cultivated plants. Many plants have been found to be incorrectly named, or have lost their names, and assistance from $\mathrm{Mr}$. I. H. BURKILX in their identification is acknowledged with many thanks. This work on the records of plants growing in the Gardens is slow, but if the records now made are kept carefully up-to-date, and checked with the plants themselves at regular intervals, they will provide a most valuable store of information.

\section{WATERFALL GARDENS, PENANG}

The rainfall for the year was 128.4 ins., which is below the average, but it was evenly distributed, except for the very wet month of April (23 ins.). The wet season during September and October was much less pronounced than usual.

The usual routine work has been maintained, and the lawns in particular continue steadily to improve in appearance. The following were the chief items of special work carried out. Above the water-lily pool a catch pit was made to avoid silting of the pool, and an alternative channel was made for the stream to direct flood water from the lily pool. Some trees beyond the pool were also felled, and the cliff face above is now clearly seen. The fern rockery was again strongly built up and concreted along the stream side, to prevent damage from floods. A set of thermometers were installed in a Stevenson screen, and readings regularly taken.

The Public Works Department constructed a new seed raising house in the nursery and this is proving very valuable. A retaining wall was also made on the stream bank above Plant House No. 3, and a new wooden bridge made across the stream below the fern rockery, to replace the old bridge, which was badly damaged by floods in 1926. Improvements of subsoil drainage were carried out by the Medical Department.

The plants of Bougainvillea Mrs. Butt opposite the office have grown very strongly and flowered most handsomely. The Gardens at Bel Retiro and Strawberry Hill have been well maintained. New plants tried with success for bedding were Buddleia variabilis and Dahlia imperialis. Aster cordifolius, introduced from Buitenzorg, has proved very successful as a potplant and a good stock of plants have been raised. The roses have been improved, and a number of new plants were introduced from England at the end of the year. The conifers and maples introduced from Japan in 1926 were planted out. The vegetable garden was extended, and a stand pipe from the new Hill water supply laid to it; this has greatly facilitated work in the garden. It has been difficult to secure an adequate supply of bullock manure for the hill gardens; this has partly been overcome by the use of fish
manure and artificials. 
The usual inspections of municipal roadside trees were carried out, and reports submitted. Advice was also given by the Assistant Curator in connection with various other outside work, chiefly connected with tree planting and felling.

\section{GOVERNMENT HOUSE DOMAIN AND OTHER
OUTSIDE CHARGES}

The usual work at Government House was carried out during the year. Planting of trees and shrubs was supervised at Rangoon Road School, Radin Mas School, St. Andrew Cathedral and by Raffles Statue.

A visit was paid to St. John's Island and advice given with regard to felling diseased Angsana trees.

Four new wreaths were prepared for the Cenotaph during the year. These have been very satisfactory. The plants used have been chiefly Hemigraphis colorata and the small varieties of Coleus. They have stood the rather extreme explosure surprisingly well; the Secretary of the Cricket Club has kindly continued to arrange for watering the wreath.

The usual inspections of roadside trees were carried out and advice given with regard to felling and planting. Four hundred and fourteen trees were felled and one hundred and thirty-three planted.

R. E. HOLTTUM, Director of Gardens, S. S. 


\title{
STRAITS SETTLEMENTS
}

ANNUAL REPORT .

\author{
of THE
}

\section{DIRECTOR OF GARDENS}

FOR THE "YEAR

\section{8}

$\mathrm{BY}$

R. E. HOLTTUM

Director of Girdens, Siruits Sellements

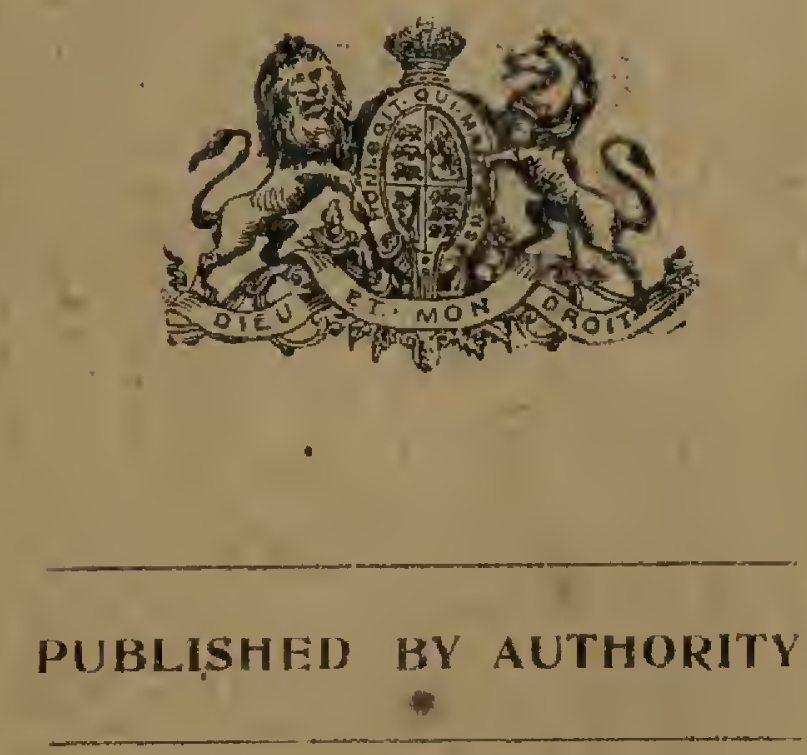

sillgapore:

Prigled at the Covernment Printing OfFice, Singaroke by $W, T$. Cherry, Government Frinter 



\section{$\theta$}

\section{Annual Report of the Director of Gardens, Straits Settlements for the year 1928}

\section{COMMITTEES}

The following gentlemen are thanked for their services as members of the Gardens Committees:-

Singapore.-

Messts. Song Ong Stang, W. Dunman, R. W. Hugries, K. B. Wrlliamson, G. Gordon Wilson and I. Laycock.

Penang.-

The Resident Councillors (Mr. R. SCOTT and Mr. MEadows Frost), The Senior Executive Engineer (Mr. F. T. Krnder), Messrs. J. D. Fettes, C. R. Samuel, the Rev. Keprel Garnter, and Mr. L. C. Brown, who resigned membership during the course of the year, having served on the Committee since its foundation.

\section{STAFF}

The Director was in charge througliont the year. Mr. M. R. Henderson, Curator of the Herbarium, was absent on leave from June ist to September I 7 th. Mr. G. A. Best was in charge of work in the Singapore Gardens, Mr. J. Lennon of other work in Singapore, and Mr. F. Flippance of the Penang Gardens, throughout the year. Mr. C. X. Furtado, Assistant Botanist, was absent on leave from 5 th April to 23 rd May.

\section{LABOUR}

The average number of gardeners and labourers employed at Singapore was 87; at Penang 66. The scale of wage's at Singapore remained unchanged; at Penang, while minima and maxima were unaltered, a scheme was adopted which will enable men to be more satisfactorily graded according to their ability and length of service.

\section{REVENUE}

\section{Singapore.-}

Sale of Plants and Seeds

$$
\$ c .
$$

Plant inspection fees

I,680 32

Freight charges, etc. recovered

23925

Sale of Guides and Postcards

$$
\cdots
$$




\section{VISITORS}

The following scientists from Overseas visited the Gardens during the year:-Dr. A. W. Hrll (Director, Royal Gardens, Kew), Dr. W. Docters van Leeuwen (Director, Botanic Gardens, Buitenzorg), Dr. J. G. Beumee (Buitenzorg), Prof. H. Burgeff (Wurzburg), Messrs. H. R. Blanford and E. O. Shebbeare (Indian Forest Service), Prof. T. D. A. Cockerell (Colorado), Dr. P. J. S. Cramer, Prof. H. von Guttenberg (Rostock), Mr. F. N. Howes (Kew), Prof. S. Hibino (Formosa), Mr. H. G. Keith (Sandakan), Mr. K. Kambe (Tokyo), Prof. H. Kniep (Berlin), Mr. F. A. McClure (Canton), Mr. W. Taylor (Kew), Dr. Y. Yabe (Tokyo).

\section{PLANT COLLECTION}

In March the Director undertook a short expedition to Gunong Muntahak and the upper tributaries of the Pelepah River in S. E. Johore.

Though few trees were flowering, a number of interesting plants were collected for the herbarium and the garden. The most notable was a new species of Pomazota (Rubiaceae), a genus hitherto only known as a single species from Pahang.

Mr. M. R. Henderson visited the Anamba Islands in April, accompanied during the first part of the expedition by Dr. C. G. G. J. Van Steenis of the Herbarium of the Botanic Gardens, Buitenzorg. The island of Siantan was first visited, and thanks are due to the Dutch Controleur and his wife, Mr. and Mrs. L. WREDE, for much kind help and hospitality. The latter half of the time was, spent by Mr. Hexderson on the island of Jemaja, while Dr. van Steenis visited the Natuna Islands. The results were rather disappointing, owing partly to the low elevation of the islands, and partly to the scarcity of plants in flower. Several interesting orchids were brought back alive to Singapore, among them very large plants of Dendrobium hercoglossum and Saccolabium Harrisonianum. An interesting plant association on an old sandy beach was studied.

During April Mr. Mohamed Haniff (formerly Field Assistant at Penang) was employed to collect herbarim material for the Gardens. He visited the foot of Gunong Bintang on the Kedah-Perak boundary, and brought back a sma1! but valuable collection, which indicates that this region wonld repay further study. Unfortunately illness of coolies and bad weather prevented Mr. HANIFF from actually climbing the mountain. He obtained, among other things, a fine Baringtonia which may prove to be new.

Between August Igth and September Ioth, the Director visited Gunong Tahan. Local arrangements had previously been made by Mr. C. E. CARR of Tembeling, who accompanied the expedition. The District Officer of Kuala Lipis kindly lent the services of the Penghulu of Kuala Tembeling, whose local knowledge anid keenness were invaluable. Collections were made by the Tahan and Teku rivers, in the valley below Wray's Camp (about 3,000 feet altitude), and on the ridge beyond, to the "padang" and summit. Mr. CARR's special knowledge of orchids resulted in the collection of a very fine series of specimens, including several additions to the flora of the Peninsula and some new species. Of other plants, many of the local species of Tahan, hitherto only known from Mr. RIDLEY's collections, are now available for distribution to other herbaria. A peculiar new Elacocarpus was obtained. A very interesting collection of ferns and mosses resulted in the addition of several species, in both groups, to the flora of the Peninsula.

\section{HERBARIUM WORK AND OTHER INVESTIGATIONS.}

Mr. Henderson continued herbarium routine work as usual, and all arrears of unnamed specimens have now been either named or sent away for determination. Assistance from the Director of the Royal Gardens, Kew, in the identification of specimens, is gratefully acknowledged. A considerable number of specimens have been lent for study, chiefly to the Buitenzorg herbarium. The study of our material in this way by specialists who are 
preparing monographs adds considerably to our comparative knowledge of Peninsula plants, and to the value of our herharium. Specimens have been lent as follows:-

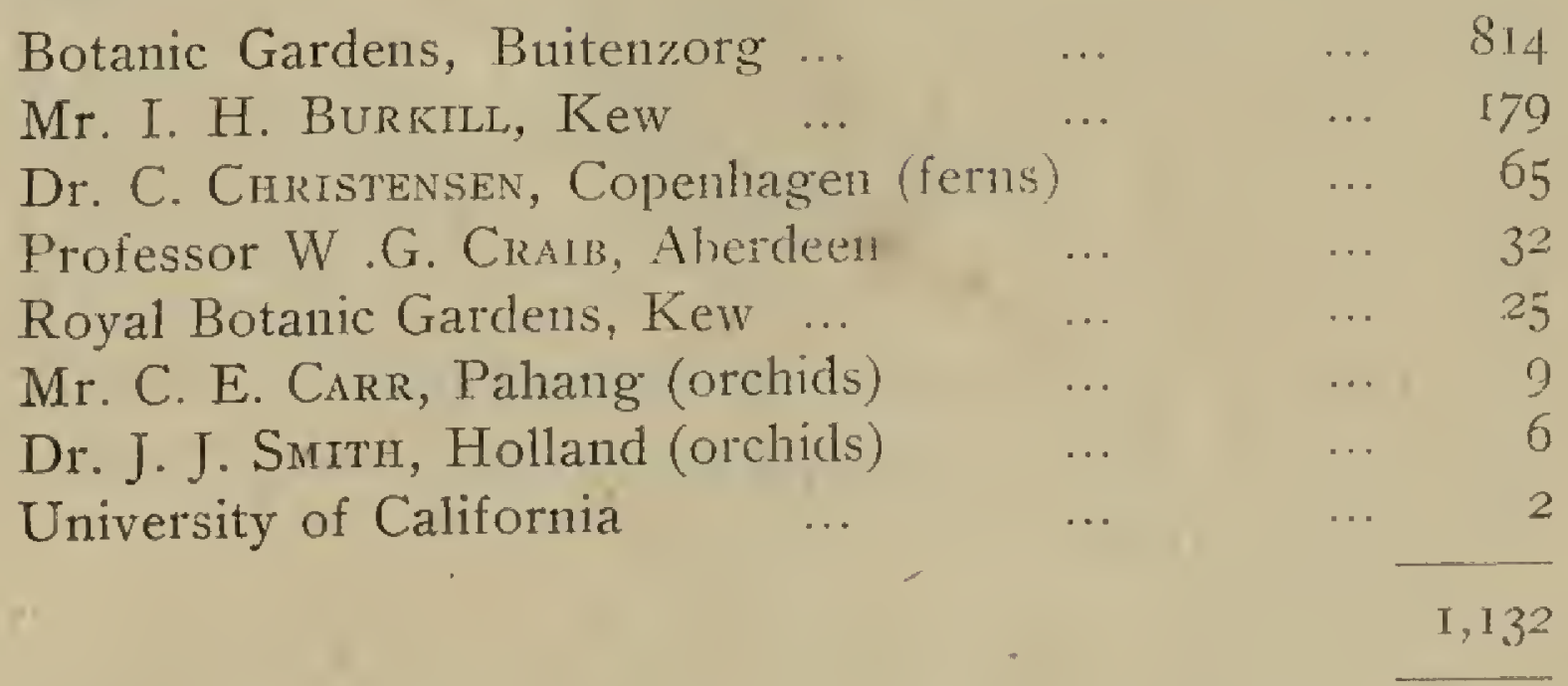

Duplicate herbarimu specimens have becul despatched as exchange to the following -

Botanic Gardens, Buitenzorg ... $\quad \ldots \quad \ldots \quad$... 832

$\begin{array}{llllll}\text { University of California } & \ldots & \ldots & \ldots & 729\end{array}$

Royal Botanic Gardens. Kew ... … ... $46 \%$

Royal Botanic Gardens, Kew (fungi for determina-

$\begin{array}{lllllll}\text { tion) } \quad \ldots & \ldots & \ldots & \ldots & \ldots & 115\end{array}$

U. S. National Herbarium (ferus and musses) $\quad \ldots \quad 359$

Bureau of Science, Manila $\quad \ldots \quad \ldots \quad \ldots \quad$... 233

Government Botanist, Brislane $\quad$.. $\quad$... 229

$\begin{array}{llllll}\text { University of Amoy ... } & \ldots & \ldots & \ldots & 228\end{array}$

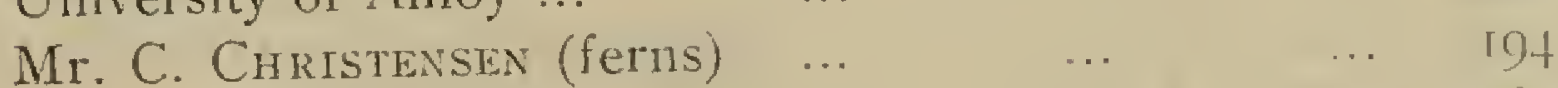

Professor S. R. BOSE (fungi) ... $\quad \ldots \quad$.. , I64

Forest Research Officer, Kuala Lumpur ... $\quad \ldots \quad 178$

Mr. H. N. Drxox (mosses for determination) $\quad \ldots \quad 162$

British Museum (Natural History) _.. $\quad \ldots \quad 121$

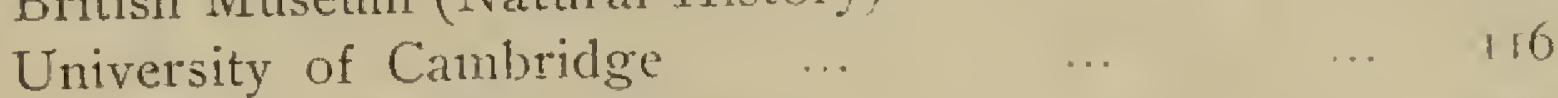

Mr. A. S. Hrtcheock (grasses) ... $\quad \ldots \quad$... $\quad$ 90

Mr. Fr Verdoorn (Frullania, for determination) ... 59

$\begin{array}{lllll}\text { Royal Botanic Gardens, Calcutta } & \ldots & \ldots & 54\end{array}$

$\begin{array}{llllll}\text { Arnold Arboretum } \ldots & \ldots & \ldots & \ldots & 52\end{array}$

Professor W. G. Crini, Aberdeen (Siamese plants) ... 28

Imperial Forestry Institute, Oxford _.. $\quad \ldots \quad 5$

M.r. I. H. BurktLl, Kew $\ldots$...

Total $\quad \ldots \quad 4.42 \mathrm{I}$

On behalf of the Director of Museums, S. S. and F. M. S., duplicates from the F. M. S. Musemuns herbarium have been distributed as follows:-

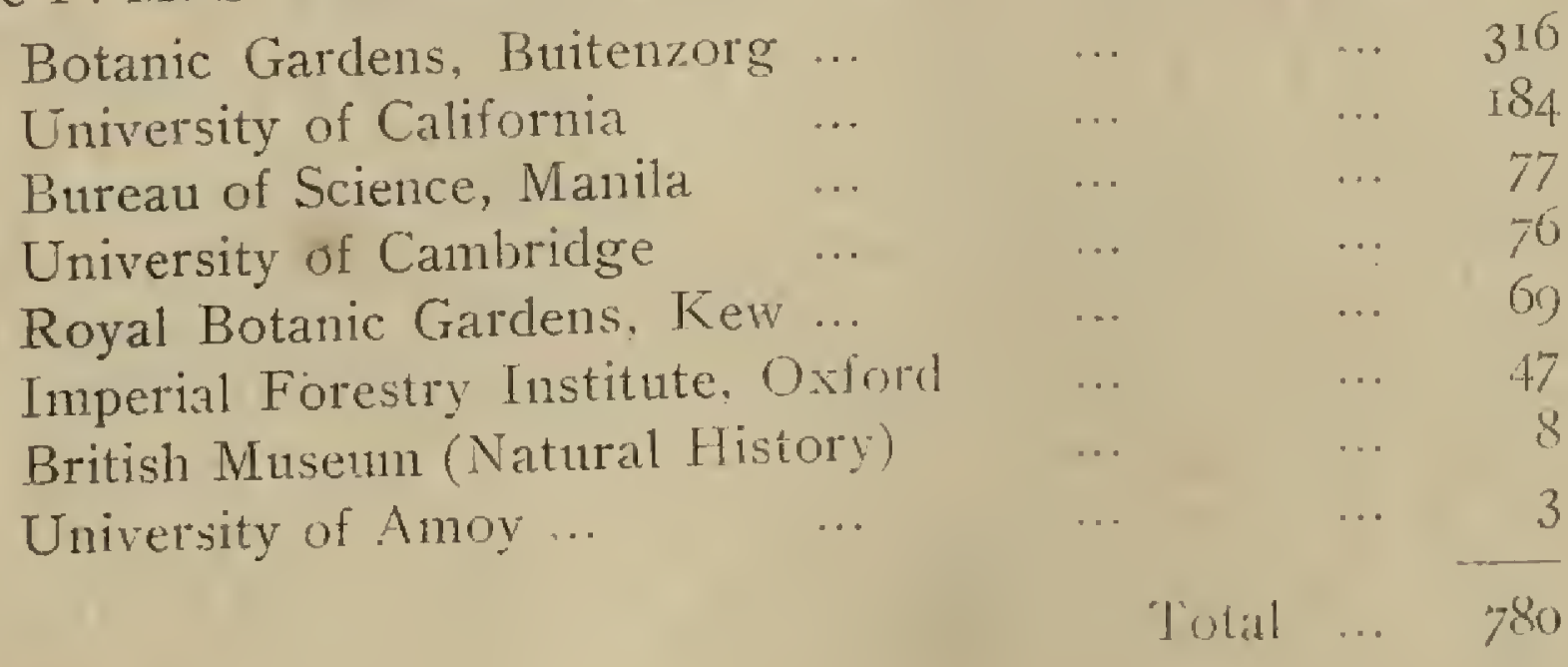


Hand timber specimens were distributed as follows:-

$\begin{array}{lllll}\text { Royal Botanic Gardens, Calcutta } & \ldots & \ldots & 5\end{array}$

Imperial Forestry Institute, Oxford $\quad \ldots \quad$... $\quad 4$

Forest Research Officer, Kuala Lumpur ... $\quad$.. 4

Total $\ldots \quad$ I3

Specimens have been received in exchange from:-

The Forest Research Officer, Kuala Lumpur;

The Botanic Gardens, Buitenzorg;

U. S. National Herbarium (ferns);

Government Botanist, Brisbane;

Arnold Arboretum;

University of Amoy;

Bureau of Science, Manila.

The Assistant Botanist, Mr. C. X. Furtado, has worked through the herbarium of cultivated plants of several families, notably the Araceae, adding many specimens of plants now in cultivation, and paying particular attention to juvenile forms and other cultural variations. Mr. FurTado prepared notes on the following for the Gardens Bulletin:- the local species of Ocimum, the genus Neesia in the Peninsula, Hyptis capitata, and Rivinia humilis.

A provisional list of plants from which seeds can be obtained for exchange purposes was prepared by $\mathrm{Mr}$. FuRTADo in co-operation with the Record Keeper, Ahmad bin Hassan. Further progress was also made by these two officers with the index of plants in cultivation.

Mr. C. E. CARr paid two visits to the herbarium, each of several days, for the purpose of studying orchids. This work has enabled him to prepare a valuable illustrated paper containing descriptions of a number of new species, chiefly collected and cultivated by himself.

Some assistance has been given by various officers to Mr. I. H. BurkiLl in connection with his Dictionary of the economic products of the Peninsula. Mr. Burkill has also very kindly identified a number of specimens of cultivated plants which have been submitted to him.

The Director has continued work in the cryptogamic herbarium, and offers thanks to the following for the identification of specimens:-Dr. C. CHristenSEn, Copenhagen (ferns); Mr. H. N. Dixon (nosses); The Director, Royal Gardens, Kew (fungi); Professor W. A. Sktchell, California (seaweeds); Mr. Fr. Verdoorn, Utrecht (Frullania); Professor S. R. Bose, Calcutta (Polyporaceae). Dr. Christensen prepared a valuable paper containing critical notes on many fern species from the Peninsula, especially in comparison with Bornean ferns. The Director also described three new fern species from the Peninsula.

Continuing the work started last year, the Director kept regular observation of the leaf changes and flowering of about roo trees in the Gardens. Regular meteorological observations also continue, including recording hair hygrograph and thermohygrograph.

The Director also succeeded in raising seeds of various orchids in sterile culture according to the method described by Knudson. The following were successfully germinated:-

Dendrobium crumenatum, Phalaenopsis violacpa, Vanda Hookeriana, Vanda teres, Vanda Miss Ioaquim, Spathoglottis plicata. Various cross pollinations were performed, and seeds of a few hybrids sown before the close of the yent. 


\section{PUBLICATIONS}

A large issue of the Gardens Bulletin, consisting of a list of plants occurring in the neighbourhood of Kuala Lumpur, prepared by Mr. Henderson, appeared in January. A further issue, containing a variety of articles by Dr. C. Christensen, Mr. R. E. Holttum, Mr. M. R. Henderson, Mr. C. X. Furtado and Mr. I. H. Burkill, went to press towards the end of the year. A paper on the ferns of Mr. Boden Kloss's expedition to the Mentawi Islands, containing descriptions of two new species, prepared by Mr. R. E. HolTtum, was published in the Journal of the Malayan Branch, Royal Asiatic Society, in March.

\section{LIBRARY}

The usual routine of binding and indexing periodicals and new books has been maintained, and some valuable old books have been rebound. A complete set of Annales Mycologici has been acquired. A beginning has been made at a subject index of literature of local botanical interest contained in periodicals and authors reprints received. Mr. C. X. Funtado has charge of this work.

\section{PLANTS OUTWARDS AND INWARDS}

The following plants and seeds were sold, sent as exchanges, or otherwise distributed:-

$$
\begin{aligned}
& \text { Singapore.- } \\
& \begin{array}{llllllll}
\text { Plants } & \ldots & \ldots & \ldots & \ldots & & \ldots & 5,129
\end{array} \\
& \begin{array}{lllllll}
\text { Cuttings } & . . & \ldots & \ldots & \ldots & 2,444
\end{array} \\
& \begin{array}{llllll}
\text { Tubers and suckers } & \ldots & \ldots & \ldots & 4,553
\end{array} \\
& \begin{array}{llllllll}
\text { Seeds } & \ldots & \ldots & \ldots & \ldots & \ldots & 286 \text { packets. }
\end{array} \\
& \begin{array}{rl|lllll}
\text { Penang. } & & & & & & \\
\text { Plants } & \ldots & \ldots & \ldots & \ldots & \ldots & 2,4 \mathrm{II}
\end{array} \\
& \begin{array}{lllllll}
\text { Seeds } & \ldots & \ldots & \ldots & \ldots & \ldots & 62 \text { packets. }
\end{array}
\end{aligned}
$$

The following plants and seeds were purchased, or received as gifts or exchanges:-

$$
\begin{aligned}
& \text { Singapore.- } \\
& \begin{array}{lllllll}
\text { Plants } & \ldots & \ldots & \ldots & \ldots & \ldots & \oint_{\mathrm{I} 3}
\end{array} \\
& \begin{array}{llllllll}
\text { Seeds } & \ldots & . & . & \ldots & \ldots & & \\
\end{array} \\
& \begin{array}{lllll}
\text { Tubers \& Cuttings } & \ldots & . & & \\
\end{array} \\
& \text { Ponang.- } \\
& \begin{array}{llllllll}
\text { Plants } & \ldots & \ldots & \ldots & \ldots & \ldots & 676
\end{array} \\
& \begin{array}{llllllll}
\text { Seeds } & \ldots & \ldots & \ldots & \ldots & \ldots & 276 \text { packets. }
\end{array}
\end{aligned}
$$

The following institutions and persons are thanked for gifts of plants and seeds :-

The Botanic Gardens at Kew, Buitenzorg, Peradeniya, Darjeeling, Poona, Saigon, Maymyo, Darwin; the Department of Agriculture Straits Settlements and Federated Malay States; the Inspector-General of Forests, New Guinea; the Ministry of Agriculture, Egypt; the United States Department of Agriculture; Plant Introduction Gardens, Panama; the Consul-General for Siam; Messrs. Ahmad bin Hassan, Juan Balme (Mexico), G. E. Brooke, H. Burgeff, C. E. Carr, H. G. Dalton, J. A. le Doux, A. T. Hancock, F. N. Howes, C. Boden Kloss, E. Krug (Brazil), Laybourne, J. Laycock, Lim Boon Keng, Mohamed Hanimi, Ng Chee Pok, O. G. Pentey, B. K. Saher, Phya Sri Sakdi, Simon de Souza, TAN Lo TeE. 


\section{BOTANIC GARDENS, SINGAPORE}

Among new plants put out during the year are the following:-..

Peltophorum africanum, Byrsonima crassifolia, Caesalpinia Gilliesii, Diospyros mollis, Eucalyptus naudiniana, Aristolochia arborea, Lagerstroemia Loudonii, Beaumontia Mertonii, Boehmeria rugulosa, B. macrophylla, Litchi chinensis, Monodora angolensis, Xylia Kerri, Salix tetrasperma, Cryptolepis elegans, Millettia Manii. and several species of Cassia. Of palms:-Chrysalidocarpus lucubescens, Phoeitix farinosa, Phoenix paradenia, Phoenx tomentosa, Dacmonorops fissus, Livistona rotundifolia, Attalea spectabilis, Arenga ambong. All the above are growing satisfactorily.

The beds containing ornamental shrubs and herbaceous plants round the bandstand hill have been partly re-arranged, and a number of duplicate shrubs removed, in order to make room for new plants and to show the existing species to better advantage. This work should be completed in ro29. An addition of 20 varieties has been made to the Hibiscus collection.

During the wet weather towards the close of the year a large area of bad grass was weeded, forked, and top-dressed with a mixture of leaf mould and artificial manures. There still remains a considerable amount of similar work to be done. The area of grass cut with light mowing machines instead of scythes has been increased.

The shade rockery for aroids and ferns has been overhatled, and many plants labelled. The Dell, at the head of the lake, has been extended by narrowing the outlet for road drainage water, and making a new path, wit a border of shade plants, leading to a seat by the lake side. The Nympliaeas in the lake have been manured, a general increase in flowering resulting. It appears that under existing conditions these plants require manuring about once in six months to maintain them in good condition. The weed in the lake was cleaned out three times during the year.

The ends of the large plant house were taken down and re-built to match the new front, and woodwork in the small plant house was renewed. Wires were fixed at regular intervals all along the front of the house, and a number of new climbing plants put out. A ristolochia gigas has been particularly suc cessful. Inside the large plant house most of the plants have been arranged according to families. The aroids in particular have received special study from Mr. FuRTADo, who has provisionally named all of them, including the large collection of exotic species. They are now arranged approximately in the order of Engler's monographs.

The small orchid garden for climbing species ( $V$ anda, frachnis; éc.) above the sun rockery has been somewhat extended; additional Plumerias have been planted near it for the purpose of supporting some of the less ornamental epiphytic species. It is hoped by extending this orchid garden to make nore room in the orchid propagation houses for the larger and more showy species, so that a better display of flowers for exhibition in the plant house may be assured. Monkeys have been troublesome in destroying flowers of some species, notably Arachnis alba.

A glass-fronted notice board had been placed at the top of the steps leading down to the plant house, for the display of a map of the Gardens, notes on plants of interest, and other notices for the public. Forty additional seats have been put out during the year, making the total in use to rather more than Ioo.

\section{WATERFALL GARDENS, PENANG}

The Garden continues to be well maintained: somewliat more development work has been carried out than in former years, owing to the increase in the labour vote by $\$ 1,000$ in the 1928 Estimates. The grass in the upper part of the Gardens is being gradually taken in hand and improved so as to permit the use of lawn mowers. The stream bank has been filled in by Plant 
House No. 3, and protected by a wall below Plant House No. 2, built by the Public Works Department. Various drains were constructed or renened. The new channel for flood water from the stream above the lily pond has been completed; this arrangement satisfactorily prevents silting of the pool. On lawn $\mathrm{E}$. a number of trees have been cut down and the ground levelled and grassed. After consultation with the Water Engineer, some trees were topped in the jungle by the Waterfall, and a greatly improved view of the Waterfall is now obtained. A plant of Adansonia digitata (the African Baobab) planted on lawn $E$. has made very good growth.

On lawn H. the Municipal Health Department have laid subsoil drains as an antimalarial measure.

The Field Assistant visited Kedah Peak in April to collect various plants for cultivation. A few plants of Matonia pectinata were brought down and kept alive in the Waterfall Gardens, though they did not thrive. The Assistant Curator visited Singapore Gardens in November, in order to keep in touch with progress of new work.

\section{GOVERNMENT HOUSE DOMAIN AND OTHER OUTSIDE CHARGES}

\section{SINGAPORE}

The usual routine work was carried out at Government House. The vegetable garden has been enlarged, and a wire fence put round this and the fower nursery. The old avenue of Sentol trees leading down to Cavanagh Road was removed and replaced by Canarium trees. Some other old and unsightly trees have also been cut down. Additional flowering shrubs have been planted. A 30 inch Dennis motor mower was in use during the latter lart of the year, and proved very successful.

The Tamil Gardeners and Coolies employed in the Domain moved to the new block of Peons' Quarters in Mackenzie Road, where they occupy the top floor. The old cooly lines were removed.

Trees were supplied and advice given about planting at Radin Mas and Outram Road Schools, Raffles College, and the Chief Tustice's House. A mixture of leaf mould and artificial manures was supplied to the Public Works Department for experimental treatment of a number of Tennis courts at Government Quarters.

The usual inspection of roadside trees was carried out. Advice was also given to the Municipal authorities concerning gardens at Adams Road Estate, and a plan for the layout of Katong Park was submitted.

The Cenotaph wreath has been maintained as in former years. Four renewals were made during the year.

\section{Penang}

The Gardens on the Hill at Penang were maintained as formerly. The difficulty of obtaining manure for them still continues. The English roses purchased in 1927 have been propagated, and some planted out. Cryptomeria japonica. Thuja delabrata and Juniperus procumbcns have grown very strongly; the other conifers imported from Japan in I926 have not succeeded, neither have the Japanese maples, which have made hardly any growth. The Azaleas have grown well and have flowered more freely. The local species Rhododcndron Teysmami has been successfully established in the Garden at Bel Retiro, and is being propagated. Among annuals newly tried, Arctotis grandis has been very successful. The supply of vegetables has been well maintained, and their quality compares favourably with that of those at other Malayan Hill Stations. 
Advice has been given by the Assistant Curator in regard to planting and grass-laying at the Residency, P. and P. W. V. C. Headquarters, Cattle Quarantine Station, and Captain Kling Mosque. Regular inspections were made of roadside trees and gardens in charge of the Penang Municipality, and reports made.

R. E. HOLTTUM, Director of Gardens,

Straits Settlements. 




\title{
ANNUAL REPORT
}

\author{
OF THE
}

\section{DIRECTOR OF GARDENS}

\author{
FOR THE YEAR
}

1929

BY

R. E. HOLTTUM

Director. of Gardens, Stratts Settlements

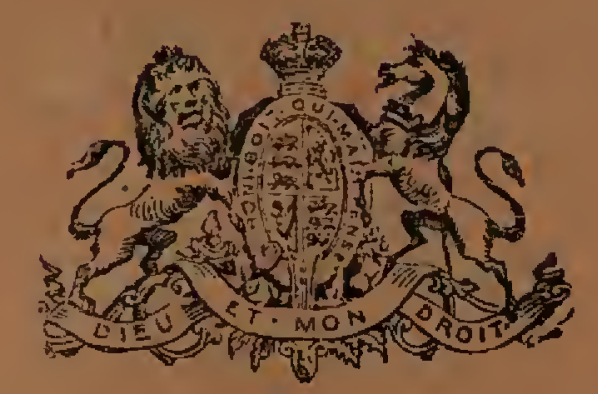

PUBLISHED BY AUTHORITY.

\section{Gingapore:}

Printed at the Government PRINTINg OfFice, SINGapore, by W. $T$. ChERRY. Government Printer. 



\section{Annual Report of the Director of Gardens, Straits Settlements for the year 1929}

\section{COMMTTTEES}

The following gentlemen were members of the Gardens Committees during the year, and are thanked for their services:-

\section{Singapore.-}

Mr. Song Ong Siang, c.b.E., The Hon'ble Mr. G. Gordon Wilson, Mr. J. Laycock, Prof. K. B. Willtamson.

\section{Penang.-}

The Resident Councillor, the Senior Executive Engineer, Mr. J. D. Fettes, the Rev. Keppel. Garnier.

\section{STAFF}

The Director was in charge throughout the year. Mr. M. R. Henderson, Curator of the Herbarium, assisted in supervising horticultural work at Singapore, in addition to his own duties, throughout the year, owing to the absence of Mr. G. A. Best at Penang. Mr. E. J. H. Corner was appointed Assistant Director and assumed duty on March ist. Mr. J. Lennon, Assistant Curator, Parks, took charge of part of the horticultural work at the Singapore Gardens in addition to his usual duties. Mr. G. A. Best, Assistant Curator, had charge of work at Penang throughout the year owing to the absence on leave of Mr. F. Flippance. Mr. C. X. Furtado, Assistant Botanist, had charge of the library and of work on the Herbarium and the index of cultivated plants.

A second plant collector was added to the staff; much of his time was occupied in collecting seeds from plants in the Gardens.

\section{LABOUR}

The average number of gardeners and labourers at Singapore was 80; at Penang 64. The minimum daily wage at Singapore was increased from 55 to 58 cents in accordance with the recommendations of the Indian Immigration Committee.

\section{REVENUE}

Singapore.-

Sale of plants and seeds

93927

Plant Inspection fees

186 o0

Freight charges, etc., recovered _... $\quad \ldots \quad 3368$ I

$\begin{array}{lllll}\text { Sale of Guides and post cards } & \ldots & \ldots & 380 & 08\end{array}$

Penang.-

Sale of plants

$$
79899
$$




\section{PLANT COLLECTIONS AND FIELD EXCURSIONS}

In March the Director took to days leave at Fraser's Hill, and while there devoted some time to studying the ferns and mosses of the neighbourhood. A fine new tree fern was discovered, and other interesting collections were made.

In April Mr. Henderson visited Pulau Tioman. Through the courtesy of the Officer Commanding the Royal Air Force Flying Boat squadron, Mr. Henderson was conveyed by air to Pulau Tioman; the journey thus occupied $2 \frac{1}{2}$ hours instead of two or three days by a small coasting steamer. A week was spent on the island, and collecting was done chiefly on Gunong Kajang and in its immediate neighbourhood.

From May Ioth to June IIth the Director was absent from Singapore, attending the Fourth Pacific Science Congress in Java, and the botanical excursions subsequent to the Congress. Personal contacts were made with botanists from the Netherlands Indies, the United States, Japan, China and other countries, and full advantage taken of visits to the Botanic Gardens at Buitenzorg and other places of botanical interest.

In July and August Mr. Henderson made an extensive field expedition to various parts of Pahang and Kelantan. Mr. C. E. CARr of Tembeling accompanied Mr. Henderson during part of the expedition. Thanks are due to Mr. CARR for much help and for the gift of many specimens of rare orchids from his collections at Tembeling; also to the District Officer, Kuala Lipis, for the loan of a motor boat. Collections of plants were made near Kuala Tembeling, and in the upper waters of the Tembeling and Sat rivers; on the limestone at Gunong Senyum, Kota Glanggi and Chigar Perah, and at Gua Musang in Kelantan. About I,000 numbers were collected, and many wood specimens of trees in flower, while abont 80 species of orchids, some of them undescribed species, were brought back to Singapore for cultivation and study. In the Ulu Tembeling opportunity was taken to study the epiphytic flora of the Neram trees (Dipterocarpus oblongifolius B1.) which are so common on the river banks. Good living specimens of the very interesting fern Platycerium Ridleyi were found at Gua Musang and brought back for cultivation at Singapore. On the return journey two days were spent at Kuantan, the coastal flora was studied, and some collections were made. At the end of October Mr. Best made a week's expedition from Penang to Baling in Kedah and collected both herbarium specimens and living plants on the limestone hill there.

In November Mr. Henderson and Mr. Corner visited Perlis. Collections were made on the limestone hills in the vicinity of Kangar and in the rice fields and pasture land. A number of Siamese plants, not hitherto known in Perlis, were collected. Specimens of the so called "gouty balsam" (Impatiens mirabilis) were obtained for cultivation in Penang and Singapore; the plants have started growth satisfactorily in both places. Impatiens Scortechimii was also brought back alive, but this and some other succulent balsams from the limestone are difficult to grow in Singapore. The small succulent fern Lastrea chupengensis Ridl. was found in a cave mouth at Bukit Chupeng in the exact spot where Mr. RidLey. first gathered specimens of it twenty years ago. "Heath" land near Kangar was investigated, but was found to be somewhat interfered with by cultivation and grazing. The vegetation consists principally of bushes of Rhodomyrtus tomentosa, and $V$ accinium sp. with a few small stunted trees and a broad leaved bamboo. Ferns were almost absent. In wetter parts the vegetation consisted almost entirely of spindly trees of Archytea Vahlii. Both the local species of sundew (Drosera indica and D. Burmanni) were found in abundance here, along with two or three small terrestrial species of Utricularia, and a minute leafless Ophioglossum which appears to be identical with O. lineare Brause, only known hitherto from a collection in New Guinea.

The abovementioned collections on the limestone hills of Pahang, Kelantan, Kedah and Perlis have added materially to our knowledge of the limestone flora of the Peninsula; Mr. Henderson is devoting particular attention to this subject. 
At various times during the year a good deal of collecting has been done in the neighbourhood of Singapore, especially by Mr. CORNER, and three short visits were paid to Gunong Panti in Johore. The Director has also made small collections during his visits to Penang.

\section{HERBARIUM WORK AND OTHER INVESTIGATIONS}

Routine work was carried out as usual in the general herbarium in the early part of the year, but after the middle of June building operations commenced and all specimens had to be packed away in the laboratory and the old office so that they were not accessible for further study. The Herbarium Assistant and plant-collectors were fully employed in collecting and drying herbarium material and seeds of plants cultivated in the Gardens, for record and identification purposes and for despatch to other botanical institutions. A collection of flowers, chiefly of orchids, preserved in alcohol, was begun in 1928 and considerably ixtended in I929. Such a collection considerably facilitates the identification of the smaller and more delicate flowers. Specimens of the new species of orchids recently described by Mr. Carr are included. Thanks are again due to the Director, Royal Bctanic Gardens, Kew, for identifications of specimens.

Duplicate herbarium specimens were despatched as follows:-

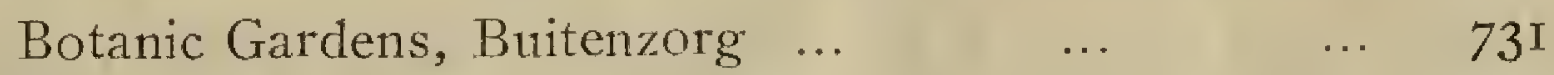

Royal Botanic Gardens, Kew ... $\quad \ldots \quad \ldots \quad \ldots 679$

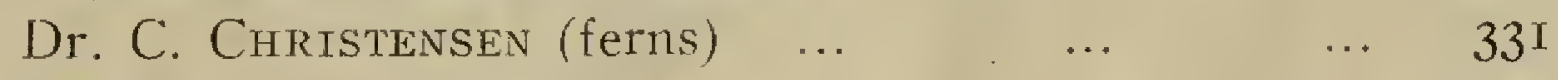

$\begin{array}{llllll}\text { University of California } & \ldots & \ldots & \ldots & 299\end{array}$

Mr. W. E. Nicholson (liverworts, for determinations) 291

$\begin{array}{lllll}\text { Bureau of Science, Manila } & \ldots & \ldots & \ldots & 202\end{array}$

$\begin{array}{lllll}\text { University or Cambridge } & \ldots & \ldots & \ldots & \mathrm{I} 67\end{array}$

$\begin{array}{lllll}\text { British Museum (Natural History) } & \ldots & \ldots & \text { I } 45\end{array}$

$\begin{array}{lllll}\text { Smithsonian Institution } & \ldots & \ldots & \ldots & 127\end{array}$

$\begin{array}{llllll}\text { University of Amoy } \ldots & \ldots & \ldots & \ldots & 106\end{array}$

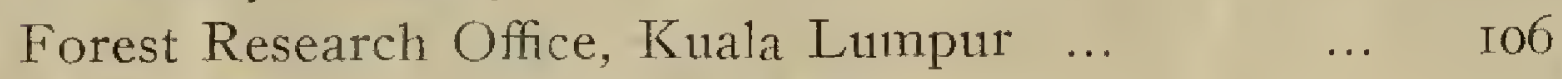

Royal Botanic Gardens, Calcutta $\quad$... $\quad$... 99

$\begin{array}{lllllll}\text { Arnold Arboretum } & \ldots & \ldots & \ldots & \ldots & 7 \mathrm{I}\end{array}$

$\mathrm{Mr}$. H. N. Drxon (mosses for identification) . .. $7 \mathrm{7r}$

$\begin{array}{lllll}\text { Sun Yat Sen University, Canton } & \ldots & \ldots & 48\end{array}$

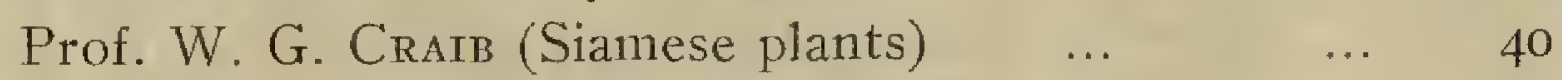

Government Botanist, Brisbane ... , ... 40

Department of Agriculture, Pretoria $\quad \ldots \quad$... 26

Imperial Forestry Institute, Oxford $\quad \begin{array}{llll}\ldots & \ldots & 20\end{array}$

Forest Research Institute, Dehra Dun ... . . . $\quad{ }^{\text {I3 }}$

Total $\ldots \overline{3,612}$

Hand timber specimens were distributed as follows:-

College of Forestry, Syracuse, U. S. A. ... $\quad$.. 8

Forest Research Institute, Dehra Dun $\quad \ldots \quad$... 7

$\begin{array}{lllllll}\text { Arnold Arboretum ... } & \ldots & \ldots & \ldots & 7\end{array}$

$\begin{array}{llllll}\text { Bureau of Science, Manila } & \ldots & \ldots & \ldots & 4\end{array}$

Forest Research Officer, Kuala Lumpur ... $\quad$... 4

Royal Botanic Gardens, 'Calcutta. $\quad \ldots \quad$... 2

\begin{tabular}{llllll} 
Botanic Gardens, Buitenzorg ... & $\ldots$ & $\ldots$ & 2 \\
\hline
\end{tabular}

Total $\ldots \quad 34$ 
Specimens were sent on loan as follows. The Gnetaceae, lent to Dr. MARKGRAF, were returned before the close of the year. The Begonia specimens lent to Prof. IRnSCHER some time ago were returned, with identifications.

$\begin{array}{llllr}\text { Dr. Markgraf, Berlin (Gnetaceae) } & \ldots & \ldots & 26 \mathrm{I} \\ \text { Royal Botanic Gardens, Kew ... } & \ldots & \ldots & 83 \\ \text { Prof. W. G. Crair (Siamese plants) } & \ldots & \ldots & 5 \\ \text { Mr. I. H. Burkill ... } & \ldots & \ldots & \ldots & 4\end{array}$

Specimens were received from the following:-

Botanic Gardens, Buitenzorg

University of California

Bureau of Science, Manila

Smithsonian Institution

University of Amoy

Dr. C. Chiristensen

Government Botanist. Brisbane

Arnold Arboretum

From the time of his arrival Mr. CORNer took charge of the cryptngamic herbarium and devoted himself actively to the collection and study of local fungi, especially Basidiomycetes, preparing full notes on about 300 species. $\mathrm{He}$ also paid some attention to marine algae, specimens of which were lespatched to Professor W. A. Setchell of the University of California, whose assistance in identification of these plants is gratefully acknowledged. Mr. H. $\mathrm{N}$. Dixon and Dr. Christensen are again thanked for determinations of mosses and ferns respectively: also Mr. Fr. Verdoorn and Mr. W. E. Nicholsox for undertaking the determination of liverworts. The Director continued to devote some time to the study of ferns, identifying so far as possible current collections and preparing for publication a paper on the Poninsula species of the genus lindsaya. In this connection thanks are due for the loan of a number of specimens for comparison from the Buitenzorg herbaritim.

The Director also continued his experimental cultivation of orchid seedlings, and by the close of the year had about a dozen hybrids in various stages of development. The aim of these experiments is to produce new free flowering orchids suitable for local cultivation: the remarkable commercial derelopment of Vanda Miss Joaquim during the past few years shows what a demand there is for plants of this kind.

The Director also continted regular observations of leaf changes and flowering of trees as in 1928 , and it is clear that some very interesting results are being obtained. A number of deciduous trees which are annual in their behaviour in regular seasonal climates here have distinctly shorter periods. For example, a tree of Poinciana regia has completed two periods of about 9 months each, whereas in seasonal climates this species changes its leaves once a year. Further it appears that most trees have a fairly regular leaf period which is not clearly connected with any climatic change. Trees of various species have periods of from six to sixteen months. Some show curious irregularities. A considerable further period of observation is needed before any definite conclusions can be reached.

\section{PUBLICATIONS}

The following issues of the Gardens Bulletin were published during the year:-

Volume 4 , Nos. II and 12 , in January, containing a variety of articles by Dr. C. Christensen, Messrs. Holttum. Henderson, Furtado and Burkill, chiefly of a systematic nature. 
Volume 5, Nos. I-2, on August I2th, consisting of descriptions and illustrations of $2 \mathrm{I}$ new species of Malayan orchids. by Mr. C. E. CARr, and notes on some other species, including five recorded for the first time in the Malay Peninsula.

A further issue went to press towards the end of the year.

Arrangements have been made for Mr. I. H. BurkilL to edit Volume 6 of the Bulletin, which is to consist of three papers on plants used medicinally in the Malay Peninsula. This volume is being printed in England concurrently with Volume 5, and the first part was completed about the end of the year.

\section{PLANTS OUTWARDS AND INWARDS}

At the beginning of the year a list of plants from which seeds can be obtained in the Singapore Gardens was printed and circulated to the Botanic Gardens in many parts of the world which have sent seed exchange lists regularly in the past. As a result, a large number of requests for seeds were received, largely for palms and for plants of economic importance. Eight hundred and forty-eight packets of seeds were in this way distributed to 32 botanical institutions. In exchange, seeds were received from the Botanic Gardens at Montevideo, Utrecht, Copenhagen, Breslau, Upsala, Paris, Glasgow, Riga, Kirstenbosch (Cape), Brisbane; from the U. S. Department of Agriculture, the Central Experimental Farm, Ottawa, the Boyce-Thompson South-western Arbor attum, the Director of Agriculture, Uganda, the experiment Station of the Hawaaian Sugar Planters Association, the Department of Agriculture, Kuala Lumpur, the Arnold Arboretum, the College of Agriculture of the Sun Yat Sen University, Canton. Plants were exchanged with the Istana Gardens, Johore, the Victoria Gardens, Bombay, and the Director of Forestry, Manila, and with a few individual persons.

Orchid plants were exchanged with the Botanic Gardens Heneratgoda, Ceylon, Messrs. William and Richard, Colombo, and Mr. W. Julran, Queensland.

Cordial thanks are expressed to the donors of many plants received during the year. The most noteworthy have been frequent gifts of Malayan orchids from Mr. J. LAycock, amounting in all to about 300 plants. Other plants and seeds have been received from the following:-

The Rev. Keppel Garnier, the Siamese Consul-General, Singapore, Dr. G. E. Brooke, Dr. N. Cooper, Messrs. Tong Takin, B. K. Saheb, J. A. Le Doux, W. A. Tyler, H. S. Whiteside, Mohamed Haniff, H. S. Banfield, H. C. Abraham, J. Zylstra, Dr. G. A. C. Herklots (Hong Kong), Dr. Carthew (Bangkok), Col. C. L. Prior and Mrs. Haughton (Penang).

The total number of plants and seeds sent out and received during the year was as follows:-

Ontzeards-

\begin{tabular}{|c|c|c|c|}
\hline igapore-Plants & $\ldots$ & $\ldots$ & $\ldots \quad 4,188$ \\
\hline Seeds ... & $\ldots$ & $\ldots$ & $\mathrm{I}, 027$ packets. \\
\hline Tubers, etc. & $\ldots$ & . & 4,893 \\
\hline Cuttings & $\ldots$ & $\ldots$ & $\mathrm{I}, 759$ \\
\hline $\begin{array}{c}\text {-Plants, cuttings, } \\
\text { Seeds } \ldots\end{array}$ & $\begin{array}{l}\text { etc. } \\
\ldots\end{array}$ & $\begin{array}{l}\cdots \\
\ldots\end{array}$ & $\begin{array}{l}\ldots \quad 4,794^{*} \\
\ldots \quad \text { IOI packets. }\end{array}$ \\
\hline
\end{tabular}

*=including 1,764 plants supplied to the Municipality.

Inwards-

\begin{tabular}{|c|c|c|c|c|c|}
\hline Singapor & $e$-Plants & & $\ldots$ & $\cdots$ & $\mathrm{I}, 4 \mathrm{I} 3$ \\
\hline & Seeds & $\ldots$ & $\ldots$ & $\ldots$ & 886 packets. \\
\hline & Cuttings, etc. & $\ldots$ & $\ldots$ & $\ldots$ & $45^{\circ}$ \\
\hline Penang & -Plants & $\ldots$ & $\ldots$ & $\ldots$ & 595 \\
\hline & Seeds ;... & $\ldots$ & $\ldots$ & $\ldots$ & 235 packets. \\
\hline
\end{tabular}




\section{THE BOTANIC GARDENS, SINGAPORE}

General Garden work.--All the more continuous areas of grass in the southern part of the garden were brought into a condition to be cut by fine lawn mowers, and were greatly improved in appearance. A light motor mower was purchased through the Crown Agents and was used to cut these lawns during the latter part of the year. Labour was thereby released to give more attention than has hitherto been possible to the rough grass of the palm valley and lawn $Z$. Towards the end of the year further areas were top dressed with various combinations of artificial manures, with a view to ascertaining the treatment which will best encourage the finer grasses.

Re-arrangement of the beds in the bandstand hill area was completed. More beds were provided for display of annual and perennial herbaceous plants and small flowering shrubs, and the following useful additions were made:-Gerbera Jamesoni, Solidago prolifica, Rudbeckia Neromanii, Aster cordifolius and Tithonia speciosa. Buddleia Davidii was unexpectedly successful, and a small plant of Berberis Fortunci, introduced from Bombay, produced flowers about the end of the year. A bed of Hydrangeas was planted as an experiment; the plants flowered but did not grow so vigorously as when cultivated in pots.

One terrace was laid out as a Canna garden for the display of the newer and finer varieties; several new varieties were added by exchange. All the climbers were provided with permanent iron supports. The lower terrace on the southern side of the hill was returfed and laid out with paved walks at right angles across it. At the intersection of the walks a hemispherical sundial was erected; the sun dial pedestal was designed and modelled by Mrs. Holttum, and cast in concrete by the bricklayer employed in the Gardens. Steps were made leading from the terrace to the lawn below, giving easy access to the main gate road and lake.

The Lake.-During the months of September and October, the lake was partially drained and cleared as completely as possible of Chara and other weeds. A considerable amount of mud was also removed from the upper end, which had become very shallow. A new outlet pipe was made through the bund about 4 feet below normal water level, so that draining may, easily be carried out in future. The Nymphaea plants were replanted after the cleaning operations, and immediately showed a much more vigorous growth than formerly.

Plant labels.-Considerable attention was paid to labelling of plants during the year. By the use of the multiple embossing press it is now possible to label fully all new plants immediately they are planted out. Four-and fiveline embossed aluminium labels are nailed to pieces of wood of the same size, and these are attached to supports of strip iron. These labels are quickly made, neat in appearance, and may be expected to last for several years. They have been used particularly on the bandstand hill and for the larger plants in the plant house. About 300 have been made, in addition to the usual larger painted labels.

Orchids.-The general collection of orchids was largely increased during the year. The additions were due partly to the considerable collections made on the field expeditions referred to above, partly to gifts, chisfly from Messrs. J. LAYCOCK and C. E. CARR, to purchases through the Malay an Orchid Society, and to exchanges. Among the plants presented by Messrs. CARR and LAYCOCK were several additions to the known flora of the Malay Peninsula; these will be recorded in the Gardens Bulletin. In April and May the large plants of Vandopsis Lowii bore I6 inflorescences and made a fine display. The orchid garden above the Sun Rockery was extende'd and now contains I4 climbing species. The Arachnis alba plants had to kie enclosed with cages of wire netting to prevent the attacks of monkeys, and the Plumeria bushes in the neighbourhood were so broken by them that the project of using these bushes as supports for smaller orchids had to be abandoned. 
Plant House.--In the plant house the systematic arrangement of plants was somewhat extended, but progress in the fern sections was held up by the collapse of the arcade supporting the climbing plants on the Cluny Road Side. The arcade was renewed and the border replanted but the section remained too much exposed to the sun to be usable. All the aroids were conspicuously labelled, and a different climbing species planted against each of the steel pillars supporting the main section of the house. A number of additions were made to the aquatic plants in the tanks, and all were labelled. Additions to the climbers on the front of the house were as follows:-Afgekia sericea, Abrus pulchellus, Gloriosa virescens, Maurandia scandens. Argyreia Hookeri and Cryptolepis elegans grew very vigorously but did not flower.

New Introductions.-A large number of seeds were received as exchanges from other gardens, and some of the resulting plants were assigned permanent places in the Garden during the year. Altogether about roo species of woody plants and palms were planted out, in addition to some herbaceous species. Among these the following trees were included: Acacia arabica, Alangium. salvifolium, Barringtonia acutangula, Canarium album, Dysoxylum angustifolium, Enterolobium cyclocarpum, Lagerstrocinia tomentosa, I. villosa, Mimusops Kanki, Myroxylum toluiferum, Sapindus rarak, Sindora cochinohinensis, Triplaris surinamensis. The following recently introduced shrubs were planted: Aphelandra coccinea, Berberis Fortunci. Callicarpa lanata, C. macrophylla, Gardenia coronaria, Ixora stricta $\%$ alba, I. undulata, Magnolia pumila, Nandina domestica, Phyllanthus atropurpurcus, P. nivosus, Pseuderanthemum seticalyx, Randia dumetorum. Rondelctia odorata, Stenolobium incisum, Strobilanthes anisophyllus, Spiraea media, Thevetia neriifolia $\%$ aurantiaca; the following climbers:-Bignonia diversifolia, $B$. excelsa, Ipomoca coccinea, Ipomea hederacca, Jacqucmontia montana, Mucuna Birdwoodiana, Tecoma radicans; and the following palms:Acoclorraphe Wrightii, Angistrophyllum secundiflomm, Hyophorbe amaricaulis, Nephrosperma van Houttenii, Pritchardia sp., Wallichia densiflora.

Owing to the fact that the Garden is in most parts already fully planted, it is difficult to find suitable places for some of the new plants, especially trees. There is still a little room for more trees in some areas, and more room can be made by the removal of some trees of species represented by numerous individuals. The larger lawns will of course be maintained as open spaces to preserve the natural beatity of the landscape.

Weather.-On the whole the year was a dry one. The total rainfall wats 86.05 inches. November was the wettest month with II.6I inches; July the driest with $2 \cdot 15$ inches. The sudden dry weather after the first week of January caused a general flowering of trees in the early part of the year, and there was a good fruit crop about June to July. The dry weather occurring later did not cause much further flowering of trees.

Notes on plants of interest.-Two Adansonia plants put out towards the end of 1927 made good growth for some months, but during the year I929 added little to their height, though they grew slowly the whole time and increased somewhat in thickness. Probably the heavy clay soil is partly responsible for the restricted growth.

Bougainvillea Maud Chuttleburgh, purchased from Messrs, L. R. Russell, Ltd., in 1925, flowered for the first time in September, I929, poorly. Evidently this is one of the varieties which will never flower freely in Singapore.

The Hydnocarpus and Taraktogenos trees, planted in 1922, have nearly all made good growth, but none have flowered yet. This is probably due partly to the somewhat shaded position they occupy.

Hand picking of beetles after dark has been resorted to in order to protect rose plants and a few others (notably $W$ arscricsia coccinea) of which all new leaves are immediately eaten by beetles. This has resulted in very greatly improved growth of the plants concerned, and a fairly good bed of rose plants has been developed. 
Two young trees of Eucalyptus Naudiniana, introduced from New Guinea and planted in 1928 made good growth. One reached a height of 15 feet in I 2 months, but was attacked by a borer, which caused the main stem to break.

Small plants of Platycerium Ridleyi were brought from Kelantan by Mr. Henderson and successfully established on trees in the Gardens and in the plant House. This species, closely allied to $P$. coronatum, has its fertile fronds directed upwards instead of downwards, and the bracket leaves clasp the supporting branch closely.

The big Jelutong tree (Dyera laxiflora) flowered heavily in April and November. It is interesting to record that the fruits resulting from the April flowering took exactly eight months to mature; they dehisced towards the end of December, though they had been full grown for some months previously.

\section{THE WATERFALL GARDENS, PENANG}

The year was unusually dry, the rainfall totalling 99.04 inches as against an average of $137^{\circ} 4$ inches for the past nine years; the dryest months were January, July and December, and much labour was required in watering plants, more especially as on some occasions the supply from the small hillside streams failed.

The usual maintenance work was continued, and in addition, various improvements were carried out as follows:--The banks of the stream along the borders of lawns $B$ and $S$ were re-made and strengthened with boulders in wire baskets, in order to prevent further erosion towards $B$; and about 1,000 sq. feet of lawn $\mathrm{S}$ near the stream was levelled and re-turfed. Smaller improvements to other lawns were also effected. The road betweet the office and the middle bridge was widened and the slope of lawn $\mathrm{C}$ on one side of it reduced, the earth secured being used to fill in the approach to the new footbridge. Considerable extensions and repairs to roadside drains were also made.

A considerable number of flowering trees and shrubs were planted in order to give more colour in various parts of the garlens, including the following:- Lagustroemia, Jacaranda, Cassia fistula, C. multijuga, Peltophorum ferrugineum, Spathodea, Poinsettia, Caesalpinia pulcherrima, Ixora and Bougainvillea.

Additions were made to the collection of ferns and other local forest plants in the fern rockery; these were collected on the hill by the Field Assistant. A number of redundant and unsightly trees we re removed from various places, notably some trees of Cinnamomum and Ficus from the thicket skirting the stream by lawn E.

Monkeys did a certain amount of damage to plants in the Gardens, though less than might be expected. They killed a palm of the species Calyptronoma Swartzii and severely damaged plants of Casuarina Rumphii and Impatiens mirabilis.

Buildings.-The Public Works Department repaired the office roof, and also supplied a steel framework for the roof of plant house No. 8, and repainted the orchid house. The gardens staff fixed new timber and bertam to the roof of plant house No. 8, and also renewed the bertam on plant house No. 9 and some of the sheds in the potting yard.

The Committee, after consulting with the Chief Police Officer, adopted new traffic regulations, which work satisfactorily, and in connection with these a new wooden foot bridge was provided to give easy access from the new parking place for motor cars to the lawns round the bandstand.

The Health Department relaid the subsoil drains in lawns $H$ and $C$, and carried out the usual programme of anti-malarial work. 


\section{GOVERNMENT HOUSE DOMAIN AND OTHER OUTSIDE CHARGES}

\section{SINGAPORE}

At Government House the grounds were maintained as usual, and the nursery of flowers and vegetables. A fruit garden was also started on the site of the formar gardeners' quarters, and the following planted in it: limes, papayas, avocado pears and bananas of several varieties. New Hibiscus hedges were planted round a considerable part of the boundary of the Domain. Several old and unsightly trees were removed, and new trees planted. Additional Howering shrubs were also planted near Government House.

The wreath on the Cenotaph has been maintained as in former years. Four renewals were made during the year. Beds of Plumbago were planted in front of Raffles Statue. Trees and shrubs were supplied for a number of new Government compounds.

Occasional inspection of roadside trees was carried out, and advice was given to the Municipal Engineer with regard to planting new trees along various roads, and the gardens at Adam Estate.

\section{Penang}

The Gardens at Bel Retiro and Strawberry Hill were maintained as usual. Great difficulty in obtaining farmyard manure on the Hill was experienced, and artificial manures combined with leaf mould were substituted. Young trees of Dacrydium elatum were planted on Gun Hill and by the path leading to Bel Retiro; I 50 flowering shrubs and trees were also planted along Summit Road. At the request of the Senior Executive Engineer, supervision of the gardeners at the four other Government Bungalows on the hill was undertaken from the month of April onwards.

The Municipal roadside trees and the gardens at Dato Kramat, the Town Hall and the Ayer Itam and Waterfall Reservoirs were regularly inspected and monthly reports submitted. Additional visits were made in several cases to inspect the progress of special work, and instruction given to the newly appointed Municipal Overseer in charge of this work. In consideration for these services, and the supply of young trees for planting, the Municipality paid \$100 p.m. to the Government revenue, as in former years.

Advice was given concerning planting and improvements to grass at the Cricket Club, Penang Club, St. George's Church and Pulau Jerajak. The usual visits to the Residency Garden were also continued.

\section{R. E. HOLTTUM, \\ Director of Gardens,} Straits Settlements. 





\section{STRAITS SETTLEMENTS}

\section{ANNUAL REPORT}

OF THE

\section{DIRECTOR OF GARDENS}

FOR THE YEAR

\section{0}

BY

R. E. HOLTTUM

Director of Gardens, Straits Settlements

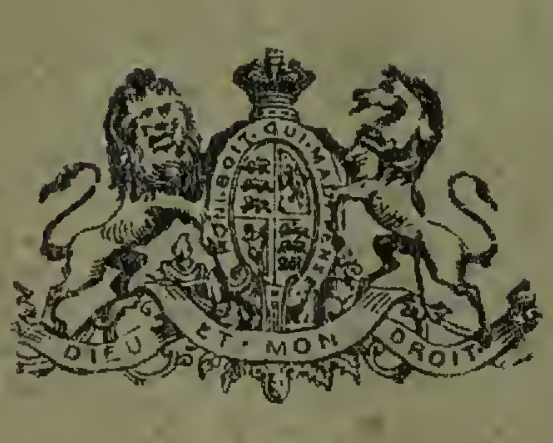

PUBLISHED BY AUTHORITY

$$
\text { Singapore: }
$$

Printed at the Government Printing OFfice, Singspore, by W. T. Cherry, Government Printes 


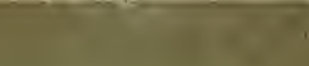

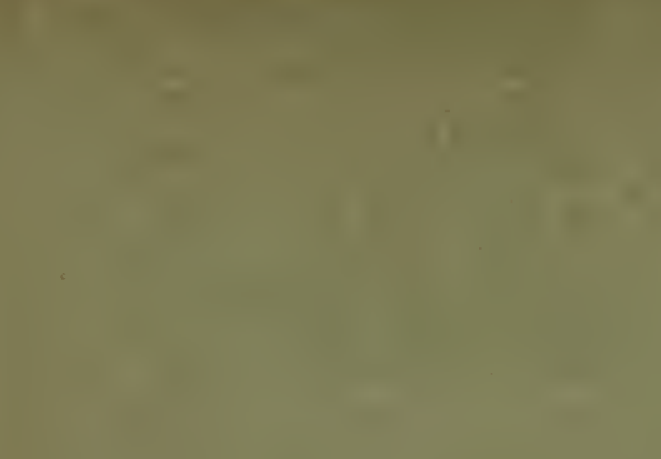

$x^{2}=2 x+2=$

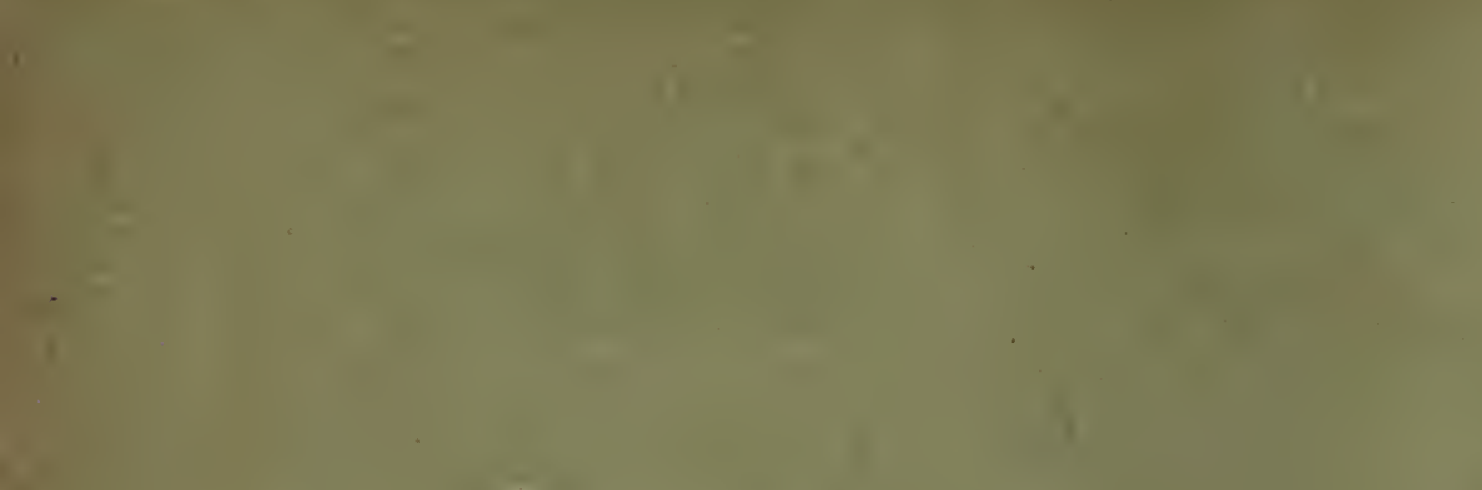

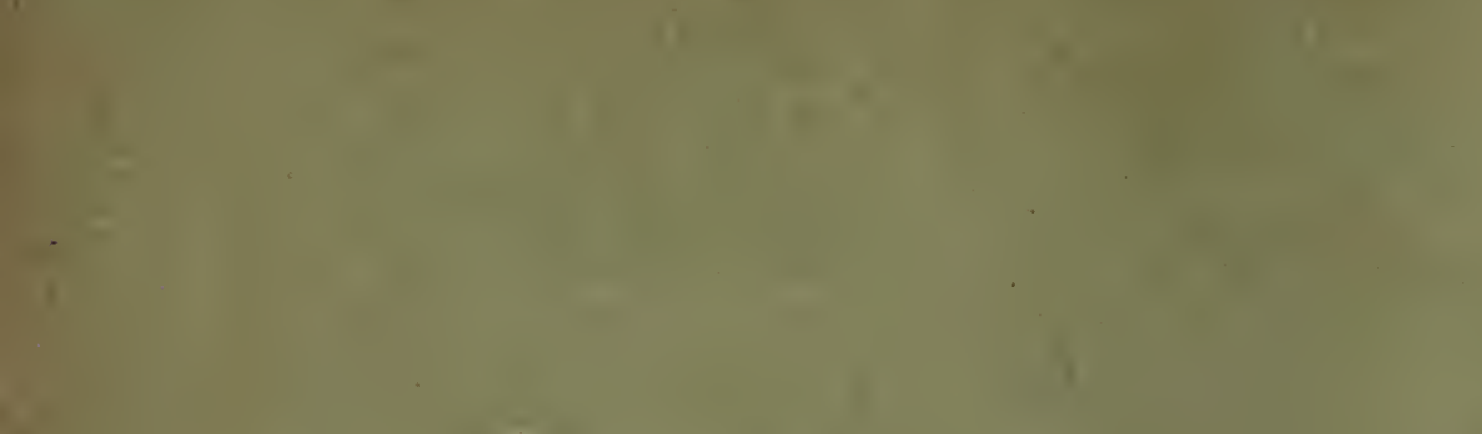

i)

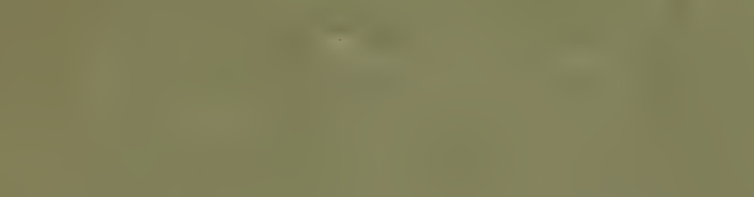

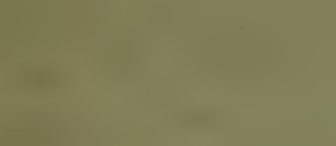

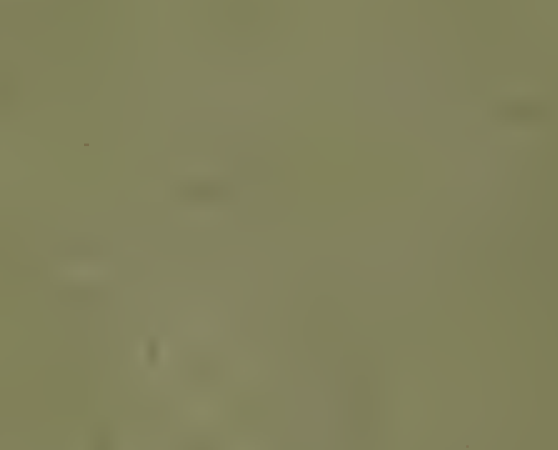

$$
\text { - }
$$

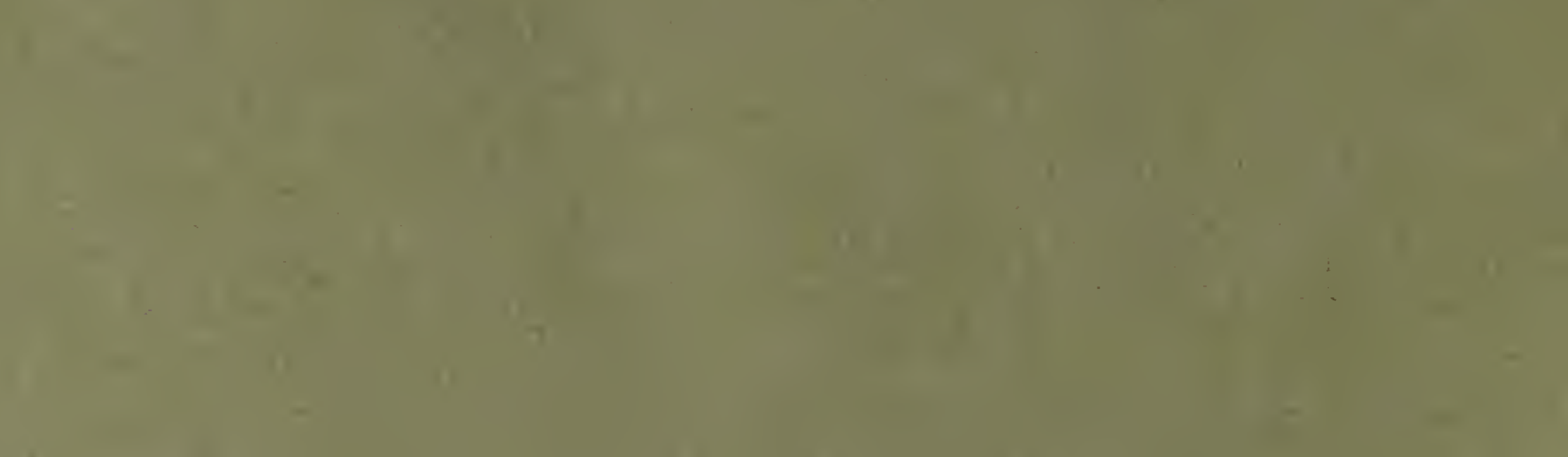

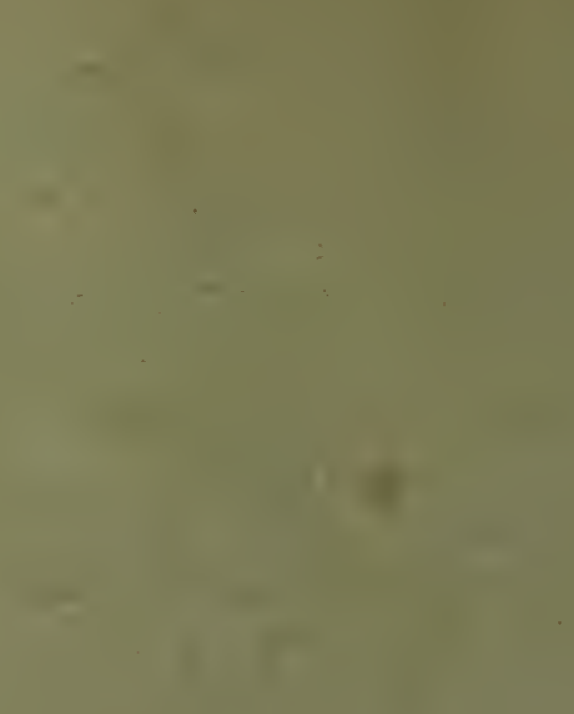

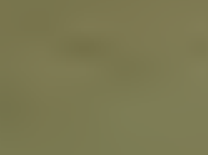
$-$

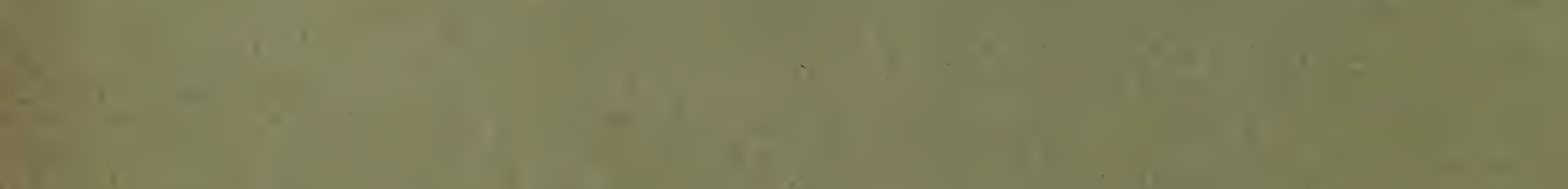

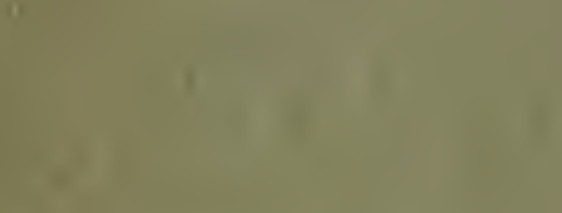

(1)

Is

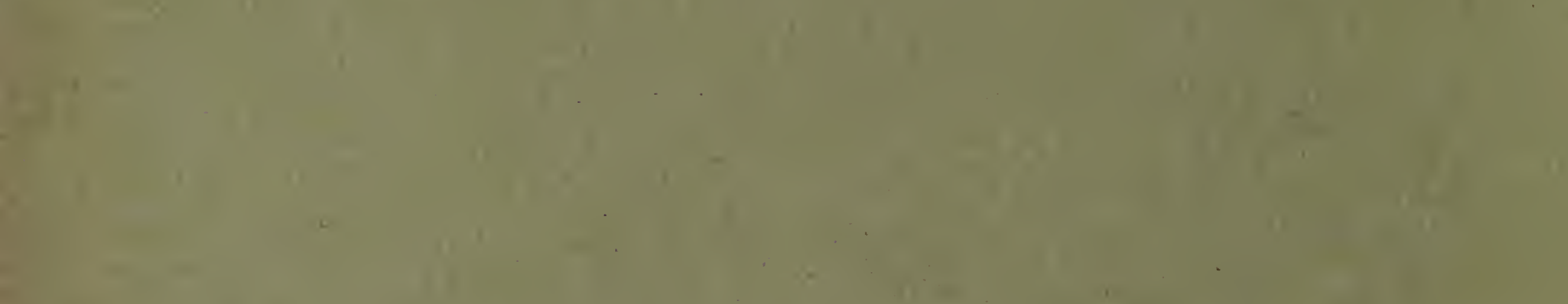

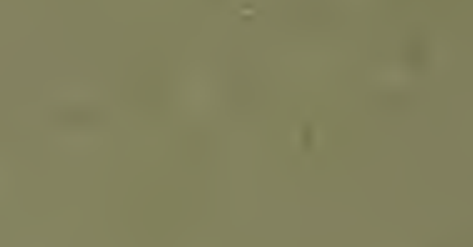

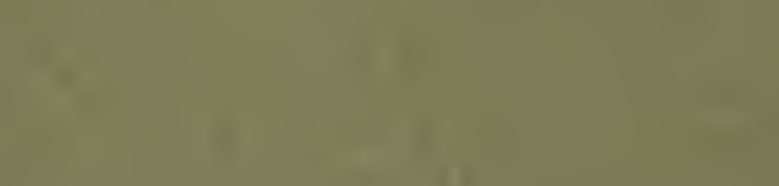

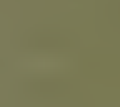

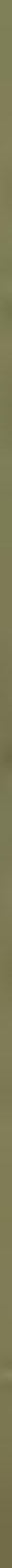




\section{Annual Report of the Director of Gardens, Straits Settlements for the year 1930}

\section{COMMITTEES}

The following gentlemen were members of the Gardens Committees during the year, and are thanked for their services:-

Singapore.-

Mr. Song Ong Stang, Mr. J. Laycock and Mr. K. B. WILLIAMSON.

\section{Penang.-}

The Resident Councillor, the Senior Executive Engineer, the Rev. Keipel Garnter and Mr. C. R. Samuet.

\section{STAFF}

The Director was on furlough from June 27 th to the end of the year. During his absence Mr. M. R. Henderson had charge of the Department. Mr. E. I. H. Corner, Assistant Director, was on duty throughout the year. Mr. G. A. BEst, Assistant Curator, Singapore, was absent on furlongh until September Igth. Mr. J. Lennon, Assistant, Curator, Parks, Singapore, was absent on furlongh from October 3 rd. The horticultural work of the Department in Singapore was divided anong various members of the staff. Mr. F. Fimprance, Assistant Curator, Penang, returned from extended furlough on Febrtiary 2ist, and had charge at Penang from that date. During the interval between Mr. BesT's departure on leave (January 9th) and Mr. Flippance's return, Mr. Abdul Kadir, Field Assistant, had charge at Penang. Mr. C. X. Furtado. Assistant Botanist, had charge in Singapore of the herbarium and index of cultivated plants, and the library, as in 1929 .

Abu Bakar bin Mohamed Hussain, Sub-overseer at Penang, died on September i2th. He was a capable officer whose services will be greatly missed. Mohamed Ariff bin Mohamen Hussan was promoted to replace Abu Barar. Ah Loo, Sub-overseer in charge of work on the Hill at Penang, was promoted to the rank of Overseer from Jantary ist, on account of the excellence of his service and the extension of the work in his charge.

The Department suffered a great loss in the death on March 25th of Mr. Mohamed Hantrf, who served on the staff at Penang from i 890 until I927, having had charge of the Waterfall Gardens from I9Io to I9I9. Mr. HANIFF continued after his retirement to take a considerable interest in the work of the Department, and frequently assisted by the collection of plants and specimens.

\section{LABOUR}

The average number of daily paid lahourers and gardeners at Singapore was 8I; at Penang 65. Rates of pay remained unchanged. The health of the staff was on the whole good: I regret to report that at Penang one Tamil cooly died of pnetumonia. 


\section{REVENUE}

Singapore.-

Sale of plants and seeds

Inspection fees ... ...

Sale of guides and post cards

Penang.-

Sale of plants and seeds ...

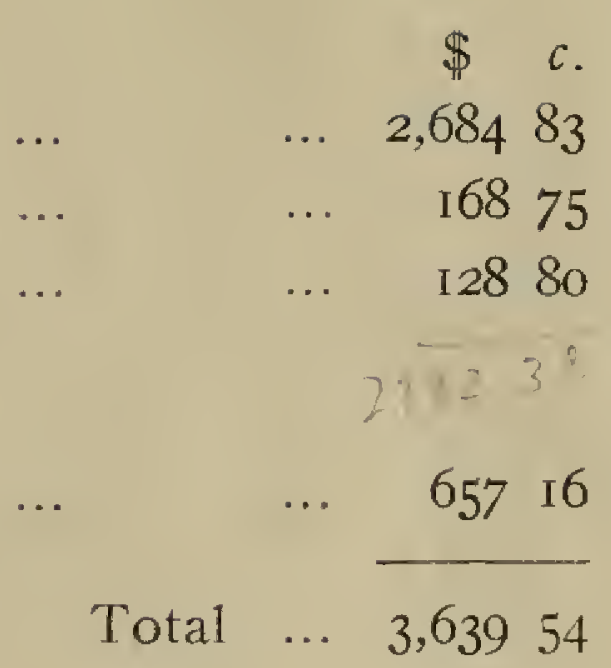

\section{PLANT COLLECTIONS AND FIELD EXCURSIONS .}

In April the Director and Mr. Henderson visited Cameron Highlands, the former spending a fortnight and the latter nearly a month at Tanah Rata. Collections were made in the Tanah Rata and on the neighbouring mountains, attention being chiefly directed to trees, of which many flowering and fruiting specimens were obtained. Herbaceous plarts had been largely collected by $\mathrm{Mr}$. Henderson on previous visits. Flowers were obtained of a tree of the family Araliacere of a genus hitherto unknown in the Peninsula; this tree is common at the Highlands and had previously not been found flowering. Another tree, of the family Hamamelidaca, is of a genus not previously known in the Peninsula. A large number of orchids were collected, particularly of the small species of Bulbophyllum which abound in this area. Cymbidimm rosemm, J. J. S., a Javanese orchid found in I928 on Gunong Tahan, was discovered at the Highlands. Of ferns a very careful collection was made, amounting to about 70 rare and interesting species. Of these the following were found for the first time in the Peninsula: Polypodium normale Don, and Dryopteris oppositipinna v. A. v. R. About six other species, not yet determined, and new to the Singapore herbarium, were also collected. Some other species had previously only once been found in the Peninsula.

At Easter the Director accompanied Mr. Fr. VERdoorn of Utrecht on a short expedition to Mount Ophir. Mr. VERdoorn made an extensive collection of liverworts, of which he has since presented a complete set to the Singapore herbarium; various other plants, chiefly ferns, were collected.

In May and June Mr. Henderson visited the limestone hills of Perak, in continuation of his study of the local limestone flora, collecting near Ipoh and Batu Gajah, on Gunong Pondok and on the small limestone hills near Lenggong. Collection was also made near Grik, particularly in the neighbourhood of the Kulim hot springs and on the banks of the Sungei Kenering. Several plants were collected at Gunong Pondok which had not been found since Kunstler first collected them in the eighties of the last century. The flora of the Lenggong limestone had previously been little known and further visits at other seasons of the year would be profitable. A number of orchids and ferns were brought to Singapore for cultivation.

In June the senior plant-collector accompanied Dr. F. W. Foxworthy, Forest Research Officer, F. M. S: on an expedition to Lower Siam, and made good collections.

In August the same collector accompanied Mr. E. J. Strugnell of the Forest Department to Cameron Highlands and down to the Telom Valley. The trip was too hurried for large collections to be made, but a number of plants of interest were obtained. 
In October Mr. Henderson visited Tasek Bera, Pahang, in company with Mr. W. Birtwistle, Officer-in-charge, Fisheries Department. The District Ofticer, Temerloh, kindly arranged to supply launches and boats. Results were disappointing as regards the number of specimens collected, but some interesting ecological observations were made.

Mr. E. J. H. Corner made two expeditions during the year, to collect fungi, chiefly Basidiomycetes. From June 23rd to July 8th, Mr. Corner visited Negri Sembilan with Dr. G. A. C. HerkLots, of Hong Kong University, and collected in the forest reserves round Kuala Pilah and Jelebu and on Gunong Angsi. Thanks are due to the District Forest Officer, Kuala Pilah, for the service of two forest guards during the stay in that neighbourhood, and to the Resident, Negri Sembilan. for permission to occupy the bungalow on Gunong Angsi. Special attention was given to fungi parasitic on the larger trees. Fomes setulosus Petch was seen commonly on the large dipterocarp trees, usually at a considerable height above the ground, and Fomes pachyphlows Pat. was found on Dialium sp. in three localities. No basidiomycetes were found, however, on the numerous trees of Damar Minyak (Agathis alba) both living and dead, winich were examined on Gunong Angsi, and the wood of this species seems exceptionally resistant to decomposition by fungi. A large variety of wood-destroying fungi were collected on the standing and fallen trunks of the Class II trees which had purposely been killed by ringing. A striking feature on Gunong Angsi was the great number of true mushrooms (Psalliota spp) which were developing in clusters through the jungle: some of these were tried at the table but they proved very unpalatable. About 350 collections of fungi were made.

From 2nd November to the 7 th December an expedition was made by Mr. Corner to Tembeling, and thanks are due to Mr. C. E. Carr, of Tembeling, for his hospitality and assistance in making local excursions. Fraser's Hill, Sungei Cheka and Kota Glanggi were also visited from Tembeling. On account of the large number of forest trees killed by the Hoods in I926 to 1927 the lowland jungle was extraordinarily rich in woodlestroying fungi. About 800 collections of fungi were made, comprising some 600 species, and three quarters of these were gathered from the rotting timber. Of special interest were numerous fructifications of Fomes sctulosus and Ganoderma sp. found parasitic on large jungle trees by the Sungei Cheka and the discovery of 9 or Io species of Geaster growing in troops on the forest floor. F. pachyphlocus was found parasitic on Ficus sp., F. pectinatus Klotz on Irvingia malayana, and Ganoderma (Fomes) applanatum on a flood damaged rubber tree. Fomes rimosus Berk, and $F$. kermes Berk were very common on the fallen timber.

A good deal of local collecting was also done by Mr. Corner in Singapore and numerous observations have been made on the seasonal appearance and the rates of development of certain fungi. Several short excursions were made also to Gunong Panti in Johore; and to neighbouring islands with Mr. W. Birtwistle, Officer-in-charge, Fisheries Department, for the purpose of collecting algae.

\section{HERBARIUM WORK AND OTHER INVESTIGATIONS}

The reconstructed Herbarium building was completed in January I930. The general herbarium of flowering plants was arranged in 7 uniform double ranks of cases (in all 84 two-unit teak cases) on the ground floor. The remaining floor space is occupied with sorting tables, storage cases, etc. The gallery holds the herbarium of cultivated plants, museum specimens and spirit collection. The extensive collection of timber specimens was handed over to the Forest Research Institute during the year.

Routine work in the herbarium continued as ustual. All I929 collection of flowering plants (amounting to about 2,000 numbers) were dealt with except the families which are in the hands of specialists at Buitenzorg. A number of new species in these collections will need further study. About 
60 wood specimens collected in Pahang in 1929 were made up and were ready for distribution at the end of the year. An alphabetical catalogue of all genera represented in the generai herbarim or howering plants was completed, with references to the numbers of the genera in the heroarium: this greatly facilitates the location of specimens. About 3,500 genera are represented. The collection of flowers (chiefly orchids) in spirit was added to during the year.

Mr. Furtado continued to work at the herbarium of cultivated plants, and as a result the names of a number of plants growing in the Gardens have been corrected and some unidentified plants named. The following families were studied in detail: Moraceæ, Urticaceæ and Cupulifeæ. At the same time a revision was made of the specimens of these families, both from Malaya and beyond, in the general Herbaritm. Mr. FurTado also located and named a large part of H. D. Forbes' Malayan collections, and attached literature references to a large number of specimens.

In the cryptogamic herbarium Mr. Corner worked on fungi throughout th year, and also dealt with collections of other groups of plants sent to specialists for determination. Mr. Conner preparel careful descriptions of 200 species of fungi and made corrections and additions to his not is on species dealt with in I929. He investigated in detail certain species of Polyporacere and wrote a paper embodying the results of his examination of Polystictus xanthopus as a preliminary to a special study of the group. The species of Boletus which are so characteristic and abundant in IValaya were also studied; the total number of these found by Mr. CoRNER now amounts to about 50. Several collections of fungi were received from the Goveriment Mycologist, Department of Agriculture, Kuala Lumpur, for identification in connection with the investigation of a disease of oil palms.

Thanks are due to the following for assistance in the identification of specimens: the Directors and staffs of the Royal Botanic Gardens, Kew and the Botanic Gardens, Buitenzorg; Mr. H. N. Drxon (mosses) Mr W. E. Nicholson (liverworts) Prof. W. A. Setchell (aigre). Mr. C. E. CatrR (orchids), Mr. Fr. Verdoory (liverworts).

Specimens were lent for study to the following:-

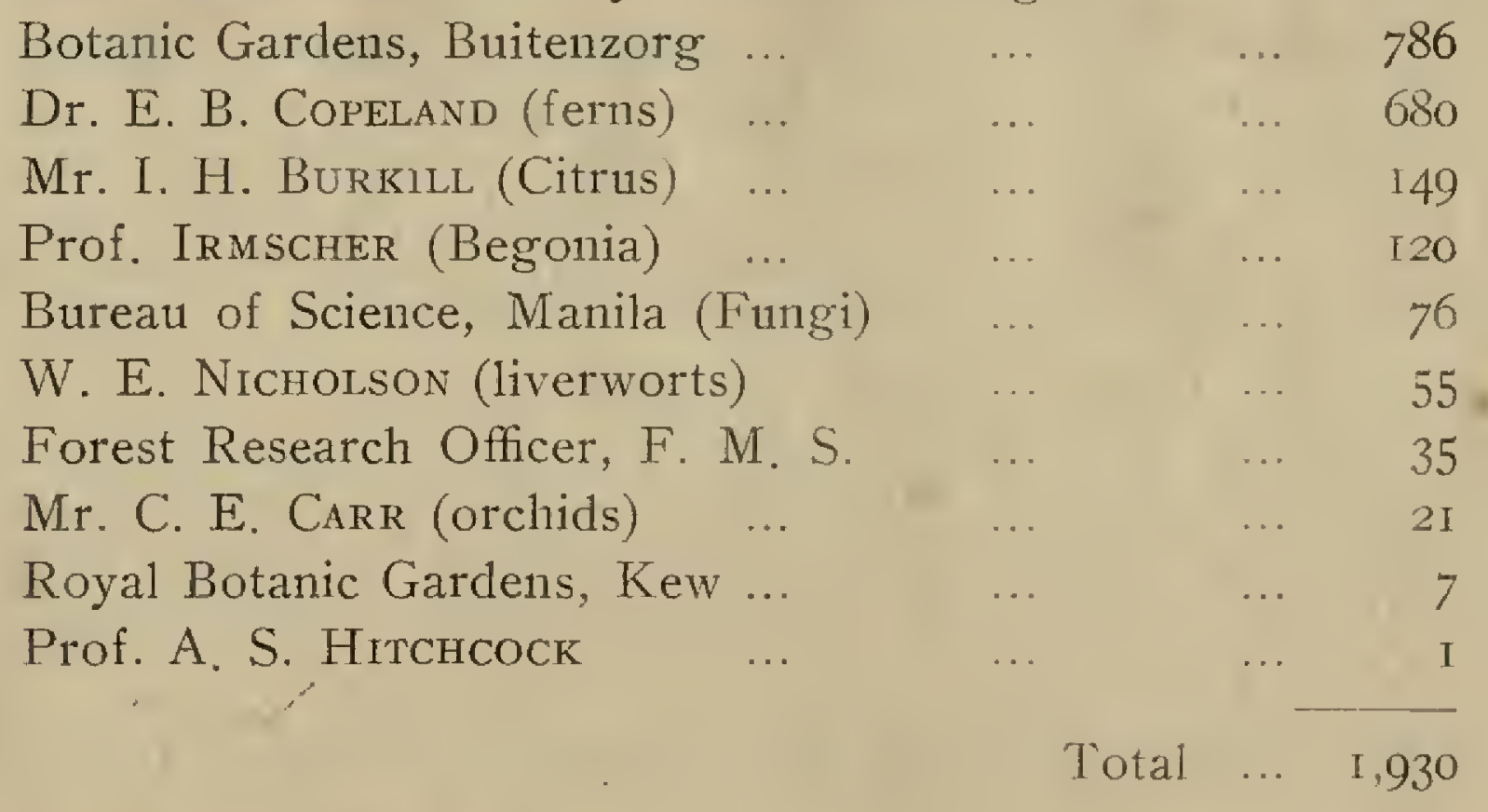

The specimens of Loranthacere lent to the Buitenzorg Herbarium for study by Dr. B. H. DANSER were returned with his identifications towards the end of the year.

The following specimens of flowering plants were monnted and laid into the herbarium :-

From the Malay Peninsula (including cultivated plants) .. 2.299

From other countries (duplicates received as exchanges) 5, 162

$$
\text { Total } \cdots \overline{7,46 \mathrm{I}}
$$


Duplicate specimens were distributed as follows:-

$\begin{array}{lllll}\text { Botanic Gardens, Buitenzorg ... } & \ldots & \ldots & 623\end{array}$

Bureau of Science, Manila ... $\quad \ldots . . . \quad$... 494

Dr. E. D. Merrill, New York $\quad \ldots \quad$... 417

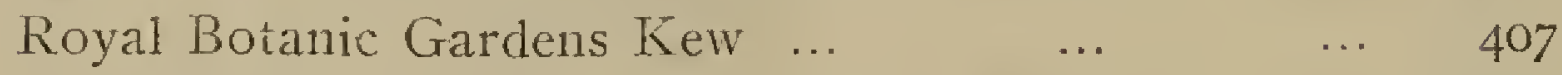

$\begin{array}{llllll}\text { University of Amoy } & \ldots & \ldots & \ldots & 314\end{array}$

$\begin{array}{lllll}\text { Royal Botanic Gardens, Calcutta } & \ldots & \ldots & 307\end{array}$

$\begin{array}{lllll}\text { Sun Yat-sen University, Canton } & \ldots & \ldots & 272\end{array}$

Forest Research Institute, Kepong $\quad \ldots \quad$... 248

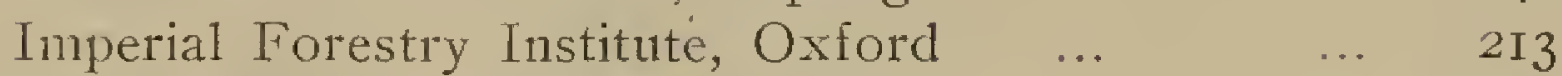

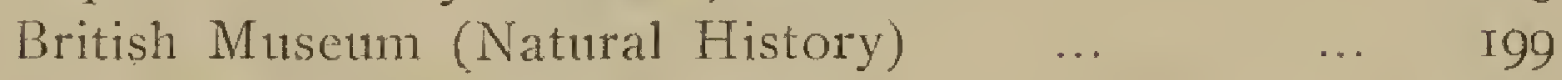

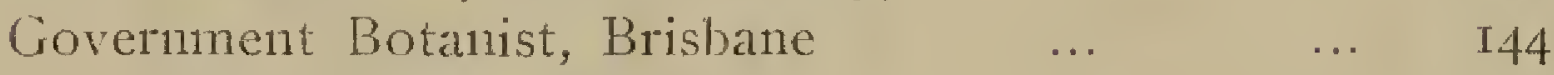

$\begin{array}{lllll}\text { U. S. National Herbarimm } & \ldots & \ldots & \ldots & \text { I37 }\end{array}$

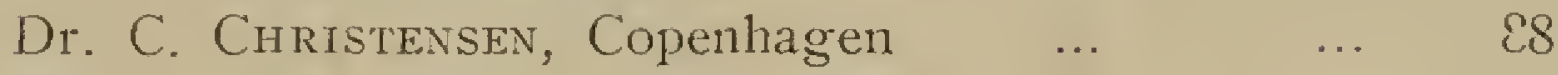

The National Herbarium, Pretoria $\quad \ldots \quad$... 74

Arnold Arboretum, U. S. A. ... $\quad \ldots \quad$...

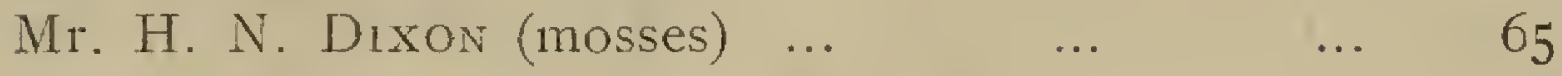

$\begin{array}{lllll}\text { Cambridge University } & \ldots & \ldots & \ldots & 60\end{array}$

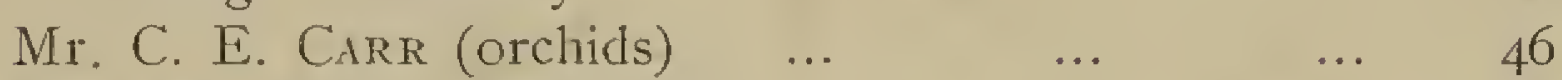

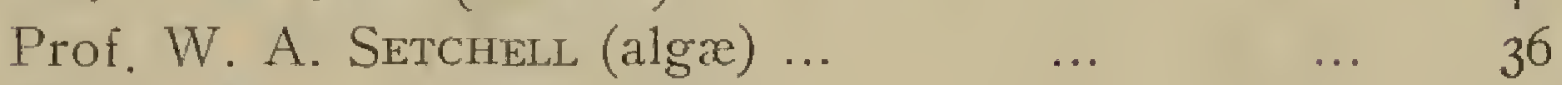

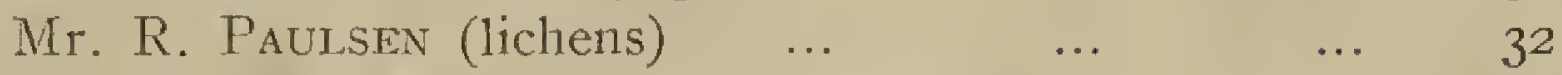

Mr. W. E. Nicholson (liverworts) $\quad \ldots \quad$... 30

Mr. I. H. Burkill (Dioscorea) $\quad$.. $\quad$... 26

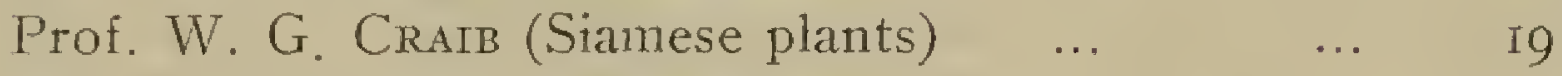

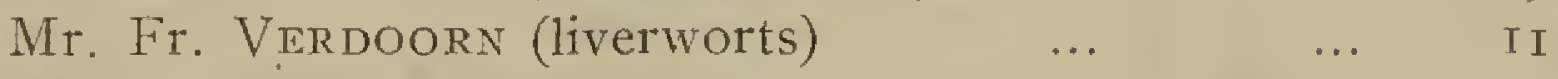

Prof. U. Marteldi (Pandanus) , $\quad \ldots \quad$...

Total $\quad \cdots \quad 4,335$

Specimens have been received in excliange from the following:-

Dr. E. D. Merrill, New York

The Botanic Gardens, Buitenzorg

The Arnold Arboretum

Sun Yat-sen University, Canton

The Bureau of Science, Manila

Forest Research Institute, Kepong

Prof. W. G. Craib, Aberdeen

Prof. W. A. Setcheli, California.

The Director continued the cultivation of young plants of orchid hybrids, referred to in previous reports; a number of plants made good progress. Also the observations of periodicity of leaf fall of deciduous trees were continued; the results to date should be ready for publication in I93I. The observations appear to indicate that a certain number of tree species renew their leaves annually, for the most part about February and March, though some change about August. A few species change their leaves at both these seasons. Indiv:duals of a considerable number of species change their leaves at fairly regular intervals but without apparent reference to any season of the year.

While on furlough the Director attended as an official delegate the International Horticultural and Botanical Congresses, held at London and Cambridge. The Horticultural Congress was also attended by Mr. G. A. BEST. These Congresses gave the opportunity of meeting other horticuitural and botanical workers from many parts of the world. Various excursions were also attended and plants seen noted for trial at Singapore 
and Penang. The Director also spent about a week working at the Herbarium at Kew, visited the British Museum (Natural History), the Botanic Gardens at Kew, Cambridge, Munich and Brussels, severai Horticultural shows, and presented a paper on Malayan ferns, illustrated by lantern slides, to the Linnean Society of London.

Mr. Henderson arranged some classes for the instruction of officers of the Preventive Service and Police Inspectors in the identification of Indian hemp and prepared descriptions and illustrations of the plant for the Monopolies Department.

\section{PUBLICATIONS}

An issue of the Gardens Bulletin, Vol. 5 Nos. 3-6, was published in June, and contaned a variety of articles on the Malayan flora. During the year the remaining two parts of Vol. 6 were published in England under the editorship of Mr. I. H. Burkill. Volume 6 as completed consists of the following parts, covering 474 pages and dealing with medicinal plants in use in Malaya:-

I. On Chinese Medicine: Drugs of Chinese Pharmacies in Malaya, by DAVID' HOOPER.

2. Malay Village Medicine: by I. H. Burkul and Mohamed Haniff.

3. The Medical book of Malayan Medicine, by J. D. Gimlette and I. H. BuRKILL.

The material for parts I and 2 was collected by Mr. Burkul, and the whole volume is due to his interest in the subjects concerned. Cordial thanks are also due to Dr. HoOper for the very great labour which he expended on part I, and to Dr. G. A. C. HERkLots of Hongkong University for preparing a list of corrigenda for the Chinese characters in part $I$.

\section{PLANTS OUTWARDS AND INWARDS.}

As in I929, a considerable demand for seeds continued from other botanical institutions in many parts of the world, and 73I packets of seeds were distributed to 35 institutions. In exchange seeds were received from Botanic Gardens at Basle, Bonn, Breslau, Buitenzorg, Calcutta, Cambridge, Coimbra, Darmstadt, Edinburgh, La Mortola, Peradeniya, Saigon, Tokyo and Upsala, the Hawaaian Sugar Planters' Association, the Station Agricole de l'Ivoloina, Tamatave, the Director of Agriculture, Bermuda, the Canal Zone Experiment Gardens, Panama, the Arnold Arboretum, and the Lancesilla Experiment Station, British Honduras.

Plants were exchanged with the Royal Botanic Gardens Kew, the Heneratgoda Botanic Gardens, Ceylon, the Superintendent, Fraser's Hill, the Department of Agriculture, Kuala Lumpur, and Dr. H. L. LYon, H.S.P.A., Honolulu. Dr. LYON sent a large collection of fine new varieties of Hibiscus, many of which are growing well in the gardens nursery, in exchange for plants of Vanda Miss Joaquim. Orchids were exchanged with Mr. W. Julian of Queensiand, Mr. R. Dury of Lyons, and Messrs. Vincke Dujardin and Co. of Bruges sent some orchid plants in exchange for palm seeds.

Thanks are again due to Mr. J. LAYCock for the gift of more than roo orchid plants: and to Mr. A. C. McLeOD for the gift of numerous orchid plants to the Waterfall Gardens. The following are also thanked for gifts of plants and seeds: Mr. B. K. Saheb, Mr. O. F. Ricketts, Mrs. Clemens, Mrs. Withers Green, Mr. Bedford (Siam), Father Cardon (Taiping), Mr. Steele (Johore), Mrs. S. Anthony (Penang) and Mr. Lim Chin Gun (Penang).

At Singapore 925 trees and shrubs were provided from the Gardens for Government buildings and new compounds; at Penang 390 trees and shrubs were provided for similar purposes and 279 young trees for Municipal Roadside planting. 
The total numbers of plants and seeds sent out and received were as follows :-

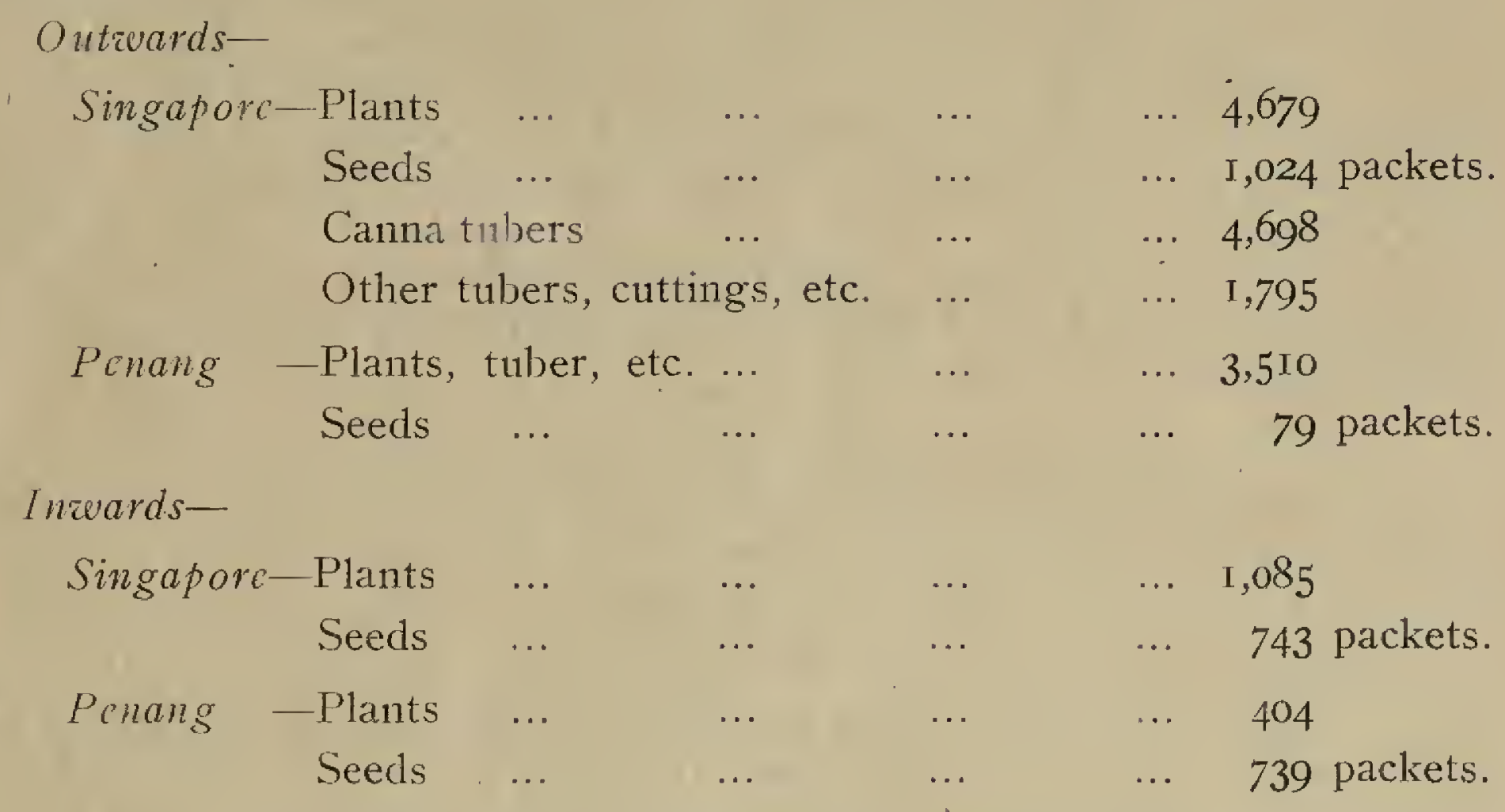

\section{THE BO'TANIC GARDENS, SINGAPORE}

General Garden Work.-A considerable amount of work was again devoted to improvement of lawns, and by the end of the year nearly the whole of the grass in the Gardens was being cut with machines. The area behind the Director's quarters which had a considerable amount of "lalang" (Imperata) in it was mown regularly with a strong large-wheeled machine. Frequent close cutting entirely killed the lalang. An additional motor mower (Dennis 24-inch) was purchased and brought into use about July, the lighter motor mower previously in use being employed chiefly on the more level lawns of the bandstand area. In the exceptionally dry weather during July and August the grass suffered badly, but quickly recovered when rainfall returned to normal.

A hand pump was installed in the nursery to pump water to a tank beside the Chinese gardener's benches; this resulted in the saving of much labour previously expended in carrying water.

The boundary along Cluny Road was fenced, the concrete posts employed being cast by the Gardens bricklayer. The vegetation on the edge of the jungle almost hides the fence, which is therefore not unsightly.

The Sun Rockery was partly re-made and replanted, and the growth of many of the smaller plants in it improved. A remarkable feature was the rapid and vigorous growth of Impatiens repens over coral rocks fully exposed to the sun.

Other new herbaceous ornamental plants which have proved successful are Rudbcckia purpurea, a small yellow flowered plant received as Zinnia lincaris, Verbcsina sp. (from Calcutta), and Sutton's pot Nasturtium.

A large number of seedling plants of local trees were planted in various parts of the Gardens Jungle, especially in places along the borders where there are gaps. Unfortunately many of these young trees were damaged by monkeys.

The lake.-Seeds of Victoria regia obtained from Kew germinated, but all the seedlings kept in Singapore died. One plant which was given to the Superintendent of Gardens, Johore, survived and came to maturity in the Istana Gardens; from this plant fresh seeds were obtained and by the end of the year three plants were established in the Singapore Gardens lake. The fine specimen of Pandamus kaida, with its pyramid of stilt roots, which adorned the island in the lake for many years, lost the last of its branches during the year, and has been removed. 
The Plant House.-A representative named collection of local epiphytic orchid plants was hung in a series round two sides of the small plant house, the arrangement being according to the series of genera in Mr. RrdLEx's Flora. About 45 genera are represented, the larger ones by several species, and it is hoped that this series of plants will give the visitor some idea of the range of form in the family as represented in Malaya, as weil as a means of identifying some common species. In addition to these, there have usually been 20 or more species of orchids flowering in the section of the house devoted to flowering plants. In May there was again a particularly fine display of flowers of V andopsis Lowii, I2 plants bearing between them 39 inflorescences.

A small section of the large plant house, in a sunny position, was roofer with glass and a collection of succulent plants in pots placed in it. 'These plants were thus protected from direct heavy rain, and have grown satisfactorily. It is hoped to extend this collection.

Recent introductions. - The following are notes on the growth of plants introduced in recent years. Afgekia sericea, from Siam, flowered in December about I8 months after planting. Argyrcia Hookcri (introduced from Darjeeling) produced a few flowers in February, nearly two years after planting. It made very vigorous vegetative growth and covered a large section of the plant house roof. Beaumontia Murtoni, introduced from Siam in 1928, has grown well on the front of the plant house, but has not yet flowered. An old plant of Bignonia Taucediana which last flowered well in September, I927, flowered very profusely in the month of March, 1930. Two plants of Byrsonima crassifolia, introduced from Egypt and planted in 1928, made good growth and flowered frequently in 1930 but set no fruit. Casalpinia gillicsii, introduced with the last named, grew rery poörly, flowered once, and died; it is unsuited to the Singapore climate. Clerodendron ugandense, introduced from Kew some years ago, has after various trials been found a satisfactory place in light shade, where it grows and flowers well; it will not stand the full sum. Its flowers are a very attractive blue colour and it should be a useful addition to our ornamental plants. Cryptolcpis clegans, a climber introduced from Darjeeling, flowered for the first time in I930.' Its Howers are small and of no decorative value, but the foliage is pleasant. Duabanga sonncratioides, introduced from Burma in I928, has made very rapid growth, two young trees attaining 20 feet in less than two years. The trees are unfortunately not of a very ornamental habit. Gloriosa virescens flowered very well, and is a great improvement on the more common $G$. superba, having larger flowers of a finer colour. Guaiacum officinale, introduced from Panama and planted in April, r93o, has made hardly 'any' growth up to the time of writing. Plants are being tried in a new position. Three plants of Hyphcene indica planted about I924 have made slow but steady growth and all have now two branches. Lagerstromia Loudoni from Siam, planted 1928, and L. tomentosa from Burma, planted I929, have both made fairly good growth; but $L$. villosa, from Burma, has grown very poorly. All these plants are very subject to attack by beetles. Maurandia semperflorens, introduced from Cambridge in 1930, flowered, very freely in a pot; it is now being tried in a bed. $M$. scandens grew but flowered very little. Monodora angolcnsis from the Belgian Congo, planted in ig28, has grown only to 2 feet in height. Mucuna Kratkei from New Guinea, said to be a very handsome species, has grown well during the past 3 years. ' It flowered' 'slightly in February, I930, but the flowers were poor. Nicodemia diversifolia, introduced from Bombay in 1929; has grown well and flowered freely. Pachira aquatica, from the Belgian Congo, planted in 1928, has grown well and flowered for the first time at the end of 1930.' Panax Guilfoylci, introdiced from Kew, was planted in 1929 and has grown well; it is useful addition to our ornamental shrubs. Quamoclit phonicia is a pretty small climber which grows wel] 
in Singapore and produces seeds freely; the Gardens plants were raised from seeds presented by Mr. C. E. CARR of Tembeling. Sapindus rarak, introduced from Burma and planted in I929, has made little growth. Sindora cochinchincusis, introduced from Saigon in 1928, has grown well. Stenolo bium incisum, from Arizona, planted in 1929, grew into a good shrub and Howered well, but unfortunately died back in the wet weather at the end of 1930. Xylia Kerii, introduced from Burma is r.928, has made good growth.

The Bandstand.-The Public Works Department erected a new bandstand during the latter part of the year and made a new sand pit for children in Lawn $R$, where new seats have been made.

\section{'THE WATERFALL: GARDENS, 'PENANG'}

The lawns in the upper part of the Gardens were improved and the use of light mowing machines extended. Some lawns adjacent to the upper north road were levelled and replanted, and in this area also the undergrowth in a patch of jungle below the road was cleared. The upper north road itself was remetalled and asphalted by the Public Works Department, and now affords a much more comfortahle and beautiful walk than a year ago. Preparations were made for laying out a terraced garden for sunloving orchids and succulents near the lower end of this road.

More Bougainvillea plants were put near the entrance to the Gardens; some additional plants were added to, the group of Dacrydium clatum in the upper part of the Garden: more tree ferns and some Cyrstostachys palms were planted in the lify pond gully; and additions made to the ferns in the fern rockery. A hedge and numerous shrubs were planted with the object of hiding the old stables by the entrance to the gardens.

A tree of Cratoxylon Maingayi was blown down in a storm. Three other trees were lost owing to termite attack.

The Bauhinia plants brought from the hill and growing over the roof of plant house No. 3 flowered for the first time.

The far end of the nursery was cleared and brought into cultivation. The nursery stands for pot plants were rebuilt entirely of reinforced concrete.

Pillars were erected by the Public Works Department at the entrance, and the adjacent hedges altered and extended to meet the pillars. Low railings were fixed by the Public Works Department to protect the edge of the lower circular road where cars are parked. Plant houses I, 4, 6, and 7 were re-roofed by the Gardens staff.

The rainfall during the year amounted to $199^{2} \mathrm{I}$ inches, which is 16 inches less than the average for the past io years. The dry seasons were normal, and the wet season prolonged but the rainfall not excessive.

The Assistant Curator visited at various times Kroh (Upper Perak), Fraser's Hill, and Anak Bukit Garden (Alor Star), bringing back plants for cultivation. The Field Assistant visited Kedah Peak and brought down plants for cultivation at Bel Retiro and in the Waterfall Gardens.

\section{GOVERNMENT HOUSE DOMAIN AND OTHER OUTSIDE CHARGES}

Singapore.-On the upper terraces in front of Government House a number of plants of Juniperus clinensis and Thuja oricntalis were planted; also some other shrubs, and a Hibiscus hedge along part of the road. A good deal of attention was given to the areas adjacent to the new Clemencean Avenue: new hedges were planted beside the fences erected by the Municipal Engineer, a number of trees planted in a group at the Cavanagh Road end, and Pterocarpus trees along the section between Kramat Road and the main entrance. Spathodea trees and bamboos were planted near the boundary of the Bukit Timah Road filter beds. 
Advice about planting was given and trees or shrubs supplied for various Government buildings, including new quarters at Mount Pleasant and Labrador, the Police Depôt, the Reformatory, the Labour Office, and Telok Kurau English School. In all 925 plants were supplied. Advice was also given as usual to the Municipality concerning the planting of roadside trees. Mr. J. Lennon gave six lectures and demonstrations on gardening to classes arranged by the Young Women's Christian Association.

Penang.-In addition to the complete control of gardening work at Bel Retiro and Strawberry Hill, the Gardens Department took over from the Public Works Department definite control of the gardens at the four other Government bungalows on Penang. Hill and at the Crag Hotel from April, 1930. The various gardens are being re-planned, and alterations will be gradually taken in hand. A Chinese gardener was installed at the Crag Hotel to deal with pot plants. The garden at the hotel has been re-planned and partly planted, but the whole scheme will take some time to complete.

Seeds of Cupressus macrocarpa and C. Knightiana were obtained from Peradeniya at the request of His Excellency the Governor, and seedlings raised for planting at Bel Retiro and elsewhere. Stokcsia cyanea flowered well and should be a useful addition to plants on the hill. A selection of 28 named varieties of Dahlias, sent out from England by the Director of Gardens, were planted at Bel Retiro at the beginning of December and nearly all made good growth.

Advice about planting was given and plants supplied for various new Government quarters, the P. \& P. W. Volunteer Corps Headquarters, Perak Road School and Captain Kling Mosque.

The ustral inspection of roadside trees and of Municipal gardens has been carried out, and advice given. Mr. Flippance submitted special reports to the Municipal Engineer on the correct treatment of young roadside trees and on pruning methods, and gave instruction to the Superintendent of roadside trees. A report on the ground adjacent to the Town Hall and Municipal Offices and a plan for planting was also prepared. In addition to the above official duties, a considerable amount of advice and assistance has been given concerning private gardens.

R. E. HOLTTUM,

Director of Gardens.

Straits Settlements. 

STRAITS SETTLEMENTS

\author{
ANNUAL REPORT
}

OF. THE

\title{
DIRECTOR OF GARDENS
}

FOR THE YEAR

\section{1}

$\mathrm{BY}$

R. E. HOLTTUM

Director of Gardens, Strats Settlements

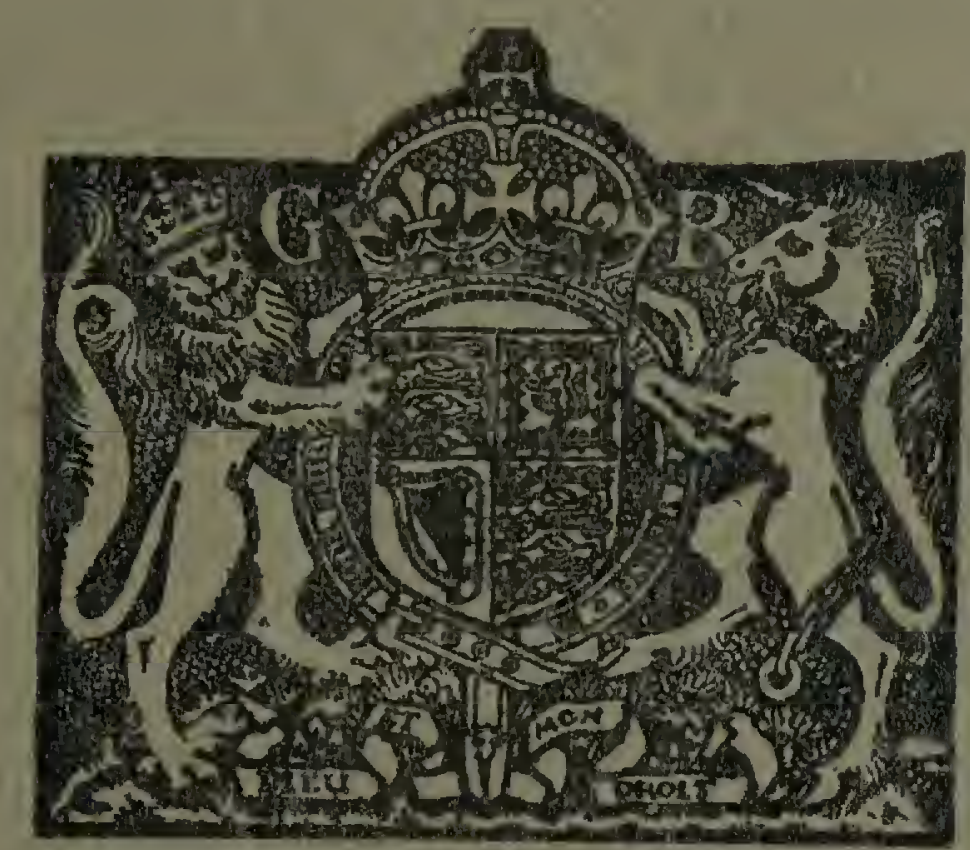

PUBLISHED BY AUTHORITY

singapore:

Printed at the Government Printing Office, Sincapore

by V. C. G. Gatrelt, Acting Government Printer 


\section{ANNUAL REPORT OF THE DIRECTOR OF GARDENS, STRAITS SETTLEMENTS FOR THE YEAR 1931}

\section{STAFF}

The Director returned from leave on January, 10th and resumed his duties. Mr. E. J. H. CORNER, Asst. Director, was in Singapore throughout the year; from August 27th he acted as Professor of Biology, King Edward VII College of Medicine. Mr. M. R. Henderson, Curator of the Herbarium was in Singapore throughout the year. Mr. F. FlipPANCE, Assistant Curator, had charge of the work of the Department in Penang throughout the year. Mr. G. A. BEST, Asst. Curator, Singapore, was on duty throughout the year. Mr. J. Lennon, Asst. Curator, Parks, Singapore, was away on furlough until June 15th. There were no changes in the local staff.

\section{LABOUR}

The average number of gardeners and coolies on daily pay employed in the Singapore Gardens was 80 , and at Penang 62 . New men at Singapore were paid at the reduced minimum rate of 47 cents per day, and others receiving 60 cents or more per day had their wages reduced by 5 cents per day during the year. At Penang rates of wages were unchanged until the end of the year. The health of the labour force was on the whole good.

\section{REVENUE}

\section{Singapore:-}

Sale of plants and seeds

Inspection fees ..

Sale of guides and posteards ..

Rent of buildings

\section{Penang:-}

Sale of plants and seeds
$\$ c$.

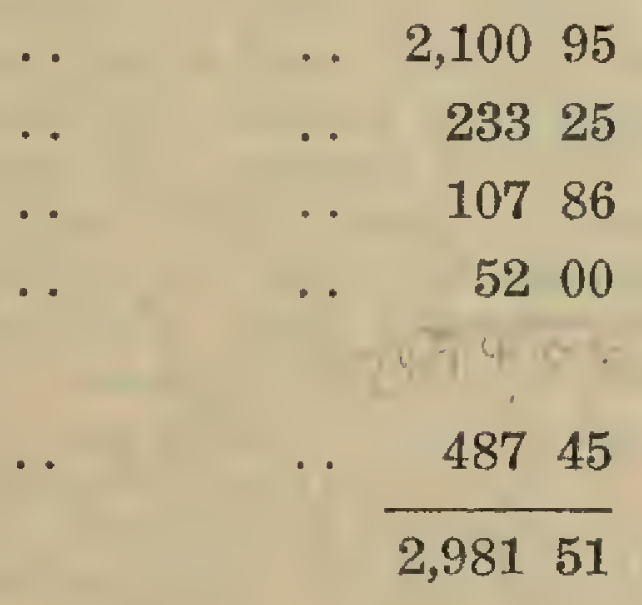

\section{PLANT COLLECTION AND FIELD EXCURSIONS}

Mr. CORNER made a short expedition to the Sedili River, Johore, in February, exploring some of the neighbouring swampy forest and collecting fungi.

The Director made a short visit to Pahang in April visiting various localities near the railway between Mentakab and Tembeling. Attention was chiefly paid to grasses and secondary growth generally; two grasses and one bamboo were obtained which were additions to the local flora (Digitaria pseudoischaemum Buese, Eragrostis tephrosanthos Schult and Schizostachyum brachycladum Kurz.) An attempt was made to distinguish between the secondary growth on the different geological formations which are found near together in that part of Pahang, but without success. It appears likely that 
the character of the primitive forest is more influenced by the geological formation than is the secondary growth which develops on cleared areas. It is certain that the ground flora of the forest on the Raub Series rocks near Tembeling and Jerantut is very characteristic.

Messrs. Corner and Henderson visited Pahang in May and June, there being a good flowering of forest trees. Particular attention. was paid to these, and good series of flowering and fruiting specimens, with a wood specimen of each, were obtained. In a small area of forest near Tembeling, which had previously been several times visited, six trees were found in flower which had never been previously collected in the Peninsula; some of these are probably new species. A short visit was paid to Sungei Ketil, at Gua Ninik in Kelantan, where the river bank flora was examined. An attempt was made to ascend the Sungei Tekai, a tributary of the Tembeling, but in the time available it was not possible to get beyond the flood-damaged area. In flood-damaged forest near the river bank was found Keenania sp. a representative of a small Himalayan genus of the family Rubiaceae. Mr. CORNER also collected a large number of fungi.

In July the Director accompanied the Chief Agricultural Officer, Johore, on a short visit to the swampy forest bordering the Sungei Endau. Thanks are due to the Government of Johore for the opportunity of making this expedition. Several interesting plants were found, including undetermined species of the following genera: Wendlandia (Rubiaceae) Tristania (Myrtaceae) Medinilla (Melastomaceae) Millettia (Leguminosae) and Toxocarpus (Asclepiadaceae). Various interesting collections of ferns were also made. On the return journey a halt was made at Tanjong Selantai and there the fern Brainea insignis was found growing abundantly; this is the most southerly record for this interesting species, which has its chief distribution from Burma to southern China and has never before been found on the mainland of the Peninsula (only at Pulau Rumbia, Lower Perak).

In September the Director paid a short visit to Cameron Highlands, at the request of the Highlands Development Committee, to report on the area called Taman Sedia. Similar areas were located near Brinchang Camp, and on one of them was found a member of the family Compositae, Ainsliaea reflexa Merr., only known previously from the Philippines and Formosa. Also in the valley of the Sengam river were found for the first time in the Peninsula the ferns Osmunda javanica (of which living plants are now growing in Singapore) and Microlepia strigosa (not previously known south of Langkawi).

In October Mr. HenDERSON visited several Limestone hills in Pahang, in continuation of his visits to the limestone districts of the Peninsula. The small. hill known as Bukit Chintamini, 11 miles south of Bentong, was first visited. Here Calanthe ceciliae was found in abundance. Bukit Serdam at Raub was climbed, but proved disappointing. There is little outcropping of limestone, and the hill appears to be covered with a very stiff slippery red clay, which supports a poor type of secondary growth. The isolated group of limestone hills near Kuantan was visited, and the largest, Bukit Cheras and Bukit Sagu, were collected upon. Impatiens Foxworthyi Hend, and I. Scortechinii Hook fil. were found in full flower. Both these hills gave a number of very interesting plants, some of which are not yet identified, and will repay further visits. Mr. V. B. C. BAKER (General Manager of the Pahang Consolidated Co). and Mr. \& Mrs. D. A. BETT are warmly thanked for their hospitality during this visit, and for free permission to use the Company's transport arrangements.

The Director made a short expedition to British North Borneo in November and December, joining the Clemens Expedition on the slopes, of Kinabalu. Thanks are due to the Government of British North Borneo, to the Resident, East Coast, and to the District Officer, Kota Belud; for assistance in making transport arrangements, and for permission to collect some orchid plants; and to Mr. and Mrs. CLEMENS for hospitality and much kind assistance. Attention was chiefly confined to ferns and mosses, as it was impossible in the time available to deal with all classes of plants; opportunity was found however to collect specimens of a number of the peculiar plants of Kinabalu which were not previously represented in the Singapore herbarium. About 300 species of ferns were found, and living plants of some of them were brought to Singapore. Living plants of Nepenthes villosa and $N$. rajah were also taken, and are now growing on Penang Hill. It was found possible to ascend the mountain, and this was done by the Tenompok route. Collections were made all along the 
ridge from Tenompok to the summit, and also in the Kadamaian valley a short distance below Kamborangah $(7,000 \mathrm{ft}$.) ; the forest near the river at this altitude was very damp, and rich in interesting fern species. On the return journey the descent was completed by the old route from Kamborangah to Lobang, and thence the forest in the neighbourhood of the Kadamaian at about 3,000 to 4,000 feet altitude was explored, many interesting plants being found. After returning to Kiau, a brief visit was paid to the Marei Parei ridge, where several species not previously seen were taken. It is hoped that an account of the ferns collected will be published later.

\section{HERBARIUM WORK AND OTHER INVESTIGATIONS}

General herbarium of Flowering Plants. Mr. HENDERSON carried on the usual routine work, and by the end of the year all collections to date had been worked over, except for the families Ebenaceae, Styracaceae, and Symplocaceae, which are in the hands of the specialists at Buitenzorg. Mr. HeNDERSON prepared a second list of additions to the flora of the Peninsula since the publication of Mr. RIDLEY's Flora, for publication in the Gardens Bulletin. Mr. HENDERSON also spent a good deal of time in preparation for three months study leave which he is to spend at Kew during 1932. Thanks are due to the staffs of the herbaria at Kew and Buitenzorg, to Mr. C. E. CARR and Dr. A. S. HITCHCOCK, for determination of critical or doubtful plants; and to the Royal Botanic Gardens Calcutta for the loan of specimens. Specimens have been received on an exchange basis from the Botanic Gardens, Buitenzor', Prof. W. G. CraIB (Aberdeen), Dr. A. F. G. KERR (Bangkok), the Imperial Forestry Institute (Oxford), the Bureau of Science, Manila, the Forestry Research Institute, F. M. S., and the Royal Gardens Kew. Specimens have been mounted and laid into the herbarium as follows:

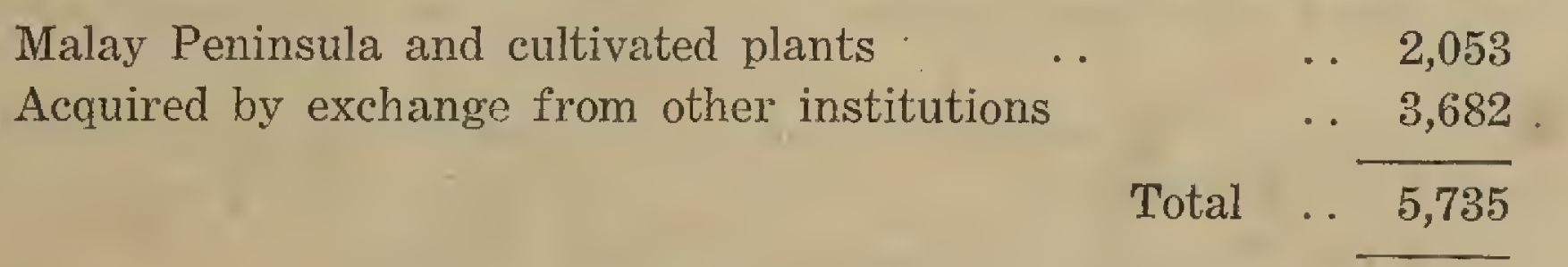

Herbarium of cultivated plants. Mr. FURTADo continued work on this herbarium, paying particular attention to the gymnosperms and the families Orchidaceae and Zingiberaceae. He also named a considerable number of specimens of plants from the Gardens, duplicates of which have been distributed to other herbaria. A number of corrections to the names of palms in the Gardens have been made, chiefly owing to the assistance of Captain $\mathrm{H}$. A. JoHNSTONE, who spent about three weeks in Singapore and gave us the benefit of his intimate knowledge of palms growing in other tropical Botanic Gardens. Cordial thanks are due to Captain JOHNSTONE for this assistance.

Cryptogamic herbarium. The Director continued work on the ferns. A short paper was published concerning Aspidium Maingayi (Baker), a curious local species which has been much misunderstood. A considerable amount of work was spent on a revision of the genus Stenochlaena, and for this purpose specimens were borrowed from the herbaria at Buitenzorg, Manila, the University of California, and from Dr. E. B. COPELAND; for the loan of these specimens grateful thanks are offered. By the end of the year a paper embodying the results of this study, and incorporating a considerable amount of original field observation, was completed; this will be published in the Gardens Bulletin.

As in former years, collections of mosses and liverworts have been sent to Mr. H. N. Dixon and to Mr. W. E. NICHolson for determination, and thanks for this service are again expressed.

Mr. CORNER devoted much of his time to the continuation of his fungus studies. He gave special attention to the systematy of the Polyporaceae and two further papers on the subject were written, one on the identity of the fungus causing the Wet-Root Rot of rubber trees, namely Ganoderma pseudoferreum, and the other on the structure of a new species of Fomes, called $F$. levigatus, grown in the Botanic Gardens. The identity of the fungus causing Brown Root of rubber trees has also been settled and the results will be published shortly under the new name of Fomes noxius. Several collections of fungi were received during the year from the Department of Agriculture, Kuala Lumpur, and the Rubber Research Institute, Kuala Lumpur, for identification. 
The difficulty of preventing collections of fungi from becoming mouldy before they can be worked over has been overcome by the use of large drying tins of galvanised iron. These tins, a convenient size for which has been found to be $2 \times 1 \mathrm{ft}$. $\times 15$ ins. high, have been so constructed that the whole upperside can be lifted off in one piece by means of a handle towards each end. The down-turned edge of the upperside fits into a narrow gutter which passes all round the top of the tin on the inside of the side-walls: the lid thus fits inside the top. The gutter is partly filled with semi-solid grease and when the lid is lowered into it an air-tight joint is made all round. The collections are packed into the tin along with a jar of anhydrous calcium chloride and some paradichlorbenzene, and they can be kept bone-dry indefinitely without deteriorating: it is advisable, however, to dry off or to replace the calcium chloride after the first month. Paradichlorbenzene has been found a most effective and cheap means of killing insects in the Herbarium, and collections of fungi, which are likely to contain beetles, are invariably treated with it before storing. The tins thus obviate the poisoning of the material with corrosive sublimate, which is the usual method adopted to prevent the glowth of moulds and which has the serious drawback that it renders microscopic examination difficult, if not impossible, by destroying the delicate tissues. The collections can be put into thin capsules of oil-paper and stowed away compactly.

A cheap and effective means has also been found for storing the bulky fruitbodies of species of Fomes, Trametes, etc., since it is impracticable to attach them to herbarium sheets in the prdinary way. Tins of galvanised ixon have been made of such a size as to fit exactly into the compartments of the herbarium cupboards. All but the very largest specimens can be stored in this way and can easily be referred to by pasting a label on the end of the tin. In this case, the collections must be poisoned before storage and two or three poisonings are sometimes required before the mould is inhibited in the wet weather.

Distribution of specimens. Specimens were lent for study to the following persons and institutions:-

Prof. W. G. CRAIB, Aberdeen (Siamese plants)

Mr. C. E. CARR (orchids)

$$
\begin{array}{ccc}
\text {.. } & \ldots & 131
\end{array}
$$

Forest Research Officer, F. M. S. (Dipterocarpaceae) .. 210

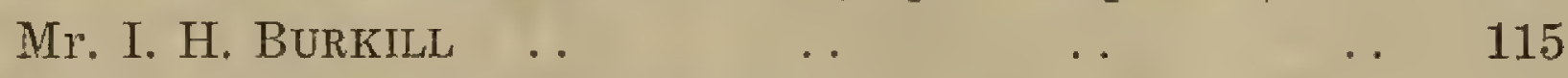

Mr. W. E. NicholsoN (Hepaticae) N $\quad$. 55

$\begin{array}{lllll}\text { Bureau of Science, Manila (Fungi) } & \ldots & \ldots & 7\end{array}$

Royal Botanic Gardens, Kew _. $\quad$. $\quad \ldots \quad 5$

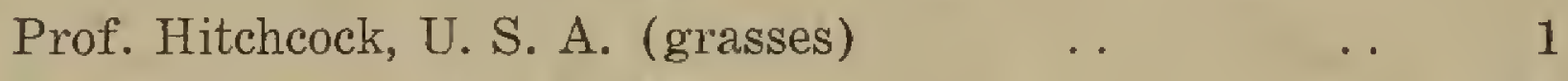

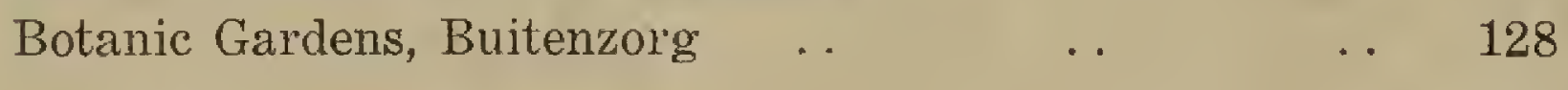

Total $\ldots \overline{1,052}$

Duplicate specimens were distributed to:-

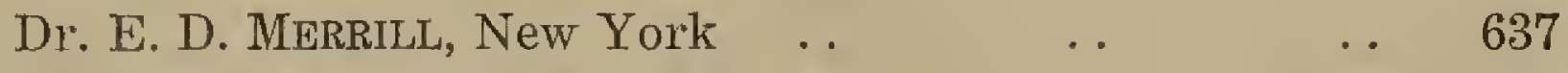

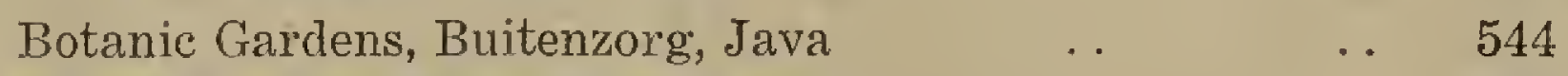

Forest Research Officer, K. Lumpur . $\quad$. 417

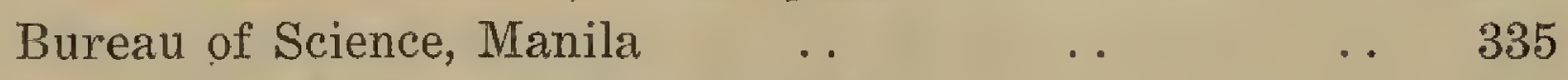

Imperial Forestry Institute, Oxford $\quad \ldots \quad \ldots 321$

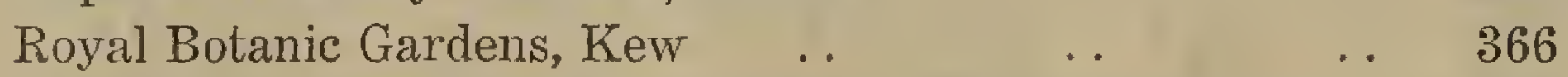

Ministry of Commerce and Communications, Banglkok . . 258

Govt. Systematic Botanist, Coimbatore, India (cult. plants) 227

Royal Botanic Gardens, Calcutta $\quad . \quad \ldots 143$

Dr. E. B. Copeland, U. S. A. (ferns) _. $\quad$.. 123

British Museum (Natural History) . . . . 105

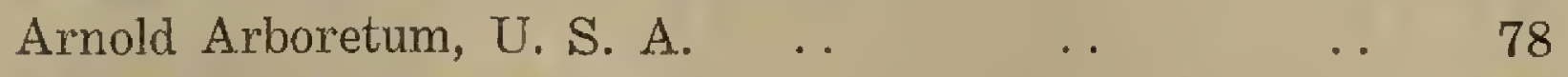

Sun Yatsen University, Canton $\quad \ldots \quad \ldots 76$

Carried forward .. 3,630 


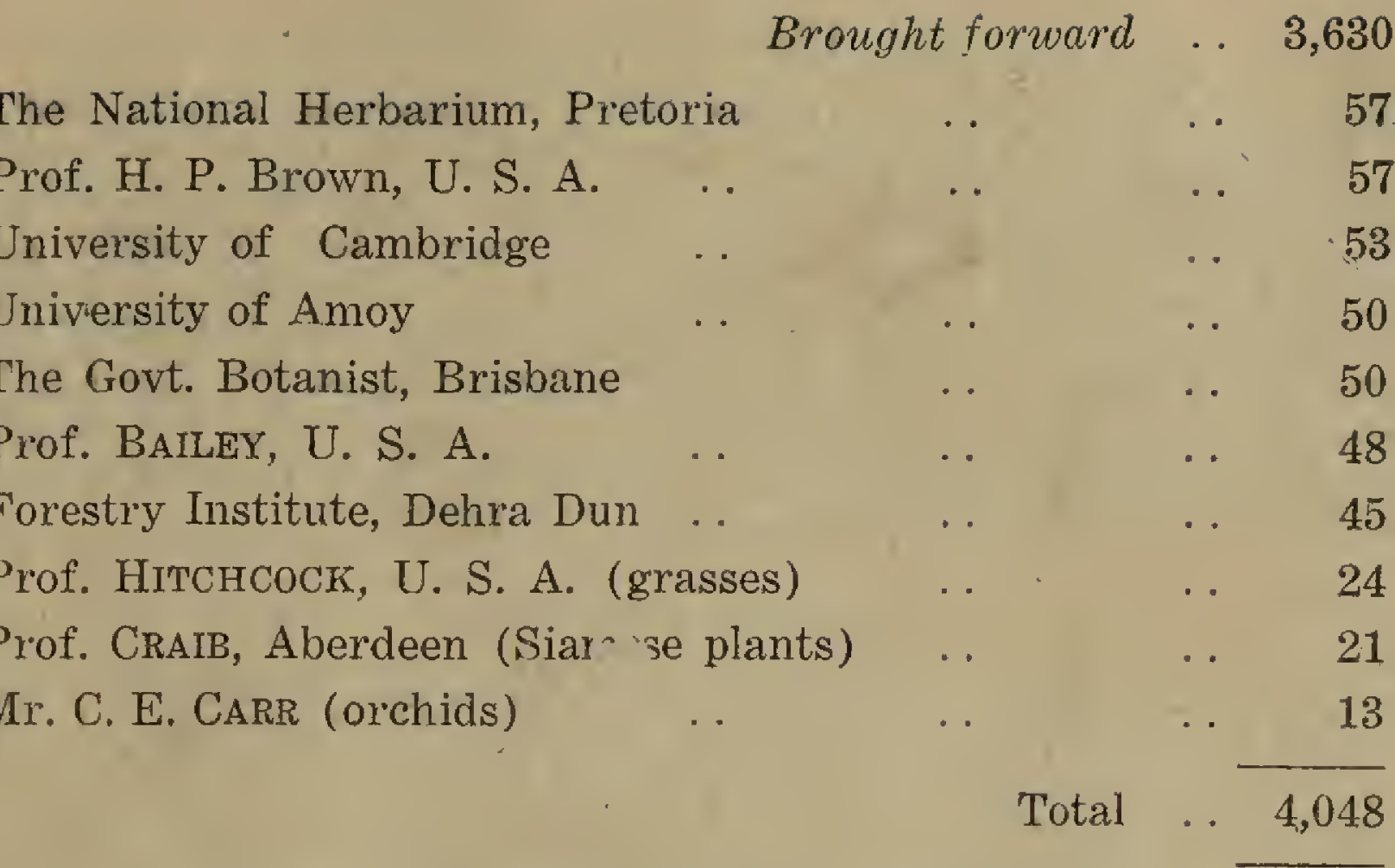

Hand timber specimens were distributed as follows:-

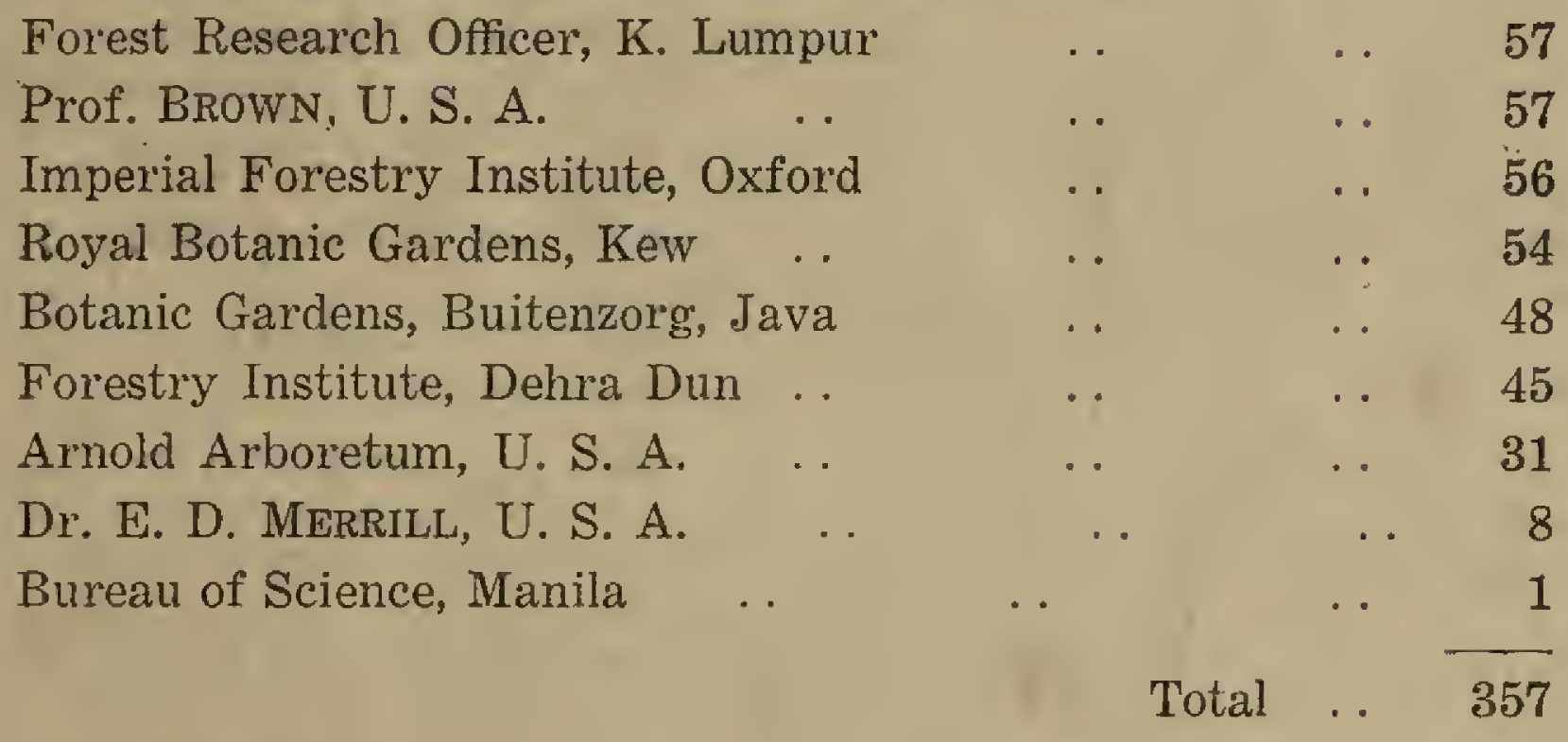

Mr. CORNER has continued his observation on the seasonal appearance and rates of development of the fungi in the Gardens Jungle. A wooden frame ( $8 \times 6 \times 3$ feet), covered on the sides and the top with mosquito-proof wire netting, was made for the purpose of growing the timber-destroying fungi and observing the rate of development of their fruit-bodies. It was designed to keep out monkeys, squirrels, snails, flies, beetles and the other numerous animals which have caused much annoyance hitherto by eating or breaking the fruitbodies, and it has proved very effective. It is kept in a shady part of the Potting Yard and the infected logs of wood are placed inside and watered twice a day.

The Director continued his observations on the periodic leaf change and flowering of trees in Singapore, and published a paper in the Gardens Bulletin summarising the results of three and a half years work on this subject. As indicated in the last report, these results indicate that some trees change their leaves annually in Singapore, usually in the early part of the year; some change regularly twice a year, about February and August; and a number of others, though annual in their behaviour in regularly seasonal climates, here change their leaves at approximately equal intervals which are not twelve or six months, individual trees behaving differently from other's of the same species. There are also some trees which are very irregular in their behaviour, being influenced probably by small fluctuations of climate; the most notable of these is the para rubber tree, Hevea brasiliensis, individuals of which undergo partial or complete defoliation at different times of the year in successive years.

The Director also continued the experimental cultivation of orchid seedlings. During the year a number of plants of the hybrid Spathoglottis aurea x S. plicata flowered, the first plants about 27 months from seed. It appears that this hybrid is quite free-flowering in Singapore; it has large flowers of a pale yellow with pale purplish markings. Other seedlings continued good growth during the year, and a number are now well established in pots. A detailed report on them was published in the first number of the Malayan Orchid Review. 


\section{PUBLICATIONS}

The only issue of the Gardens Bulletin published during the year was Vol. 5 nos 7-8, issued on June 3rd. In addition to the paper on periodic flowering and leaf fall of trees referred to above, the issue contained papers by Mr. I. T. BuRKILL on the local species of Citrus and its allies, and on the specigs of Gluta (which with its allied genera constitute the group of poisonous trees known as rengas); also a description of a new hybrid Vanda (V. X Broumaniae) by Dr. J. J. SMITH, a short account of the "padang" flora of Tamaja, in the Anamba Islands, by Mr. M. R. HENDERSoN, and notes on Aspidium Maingayi (Baker), Herpestis Monniera II. B. K., Erythropsis colorata Burkill, and Halophila spinulosa (R. Br.) Aschers.

\section{THE LIBRARY}

Capt. H. A. JoHNSTONE presented to the Gardens Library a copy of the portion of Martius' Flora Brasilicnsis dealing with the palms. For this valuable gift cordial thanks are expressed. The subject catalogue of literature dealing with local plants was continued, and is proving very useful.

\section{PLANTS OUTWARDS AND INWARDS}

There was a decrease of sales of plants both at Singapore and Penang, and also a decrease in the number of seeds distributed to other Garderis. Seeds were distributed from Singapore to 47 botanical institutions, and seeds received from 28 institutions. Plants were exchanged with Dr. H. L. LYON, H. S. P. A. Honolulu; the Royal Botanic Gardens, Kew; the Chandra Nursery, Sikkim; Mrs. M. A. Williames, Rangoon; the Agriculturist, Kuala Lumpur; the Superintendent of Gardens, Johore; the Superintendent, Fraser's Hill; Anak Bukit Garden, Kedah; the Quarantine Camp, Penang.

The following donors of plants and seeds are gratefully thanked: Mr. J. LAYCOCK, Singapore (orchids); Mrs. ANTHONY Penang; Mr. B. NICHoL, Penang; Dr. M. CARTHEW, Bangkok (a plant of Phyllocarpus septentrionalis); Mr. B. K. SAHEB, Singapore; L. A. Dreyfus Co., Singapore (Bornean guttaproducing plants); Mrs. WATERHouse, Singapore; Mr. Gordon SPARE, Johore; Mr. L. Desborough, Johore; Mr. W. G. STIRLING, Singapore (orchids); Mr. F. S. BANFIELD, Taiping; Mr. VAN HAELEN (Bulbophyllum Beccarii).

At Singapore 1,386 trees and shrubs were provided for planting in the grounds of Government buildings, schools, etc., and at Penang 277 trees and shrubs for Government and Municipal requirements. follows :-

The total numbers of plants and seeds sent out and received were as

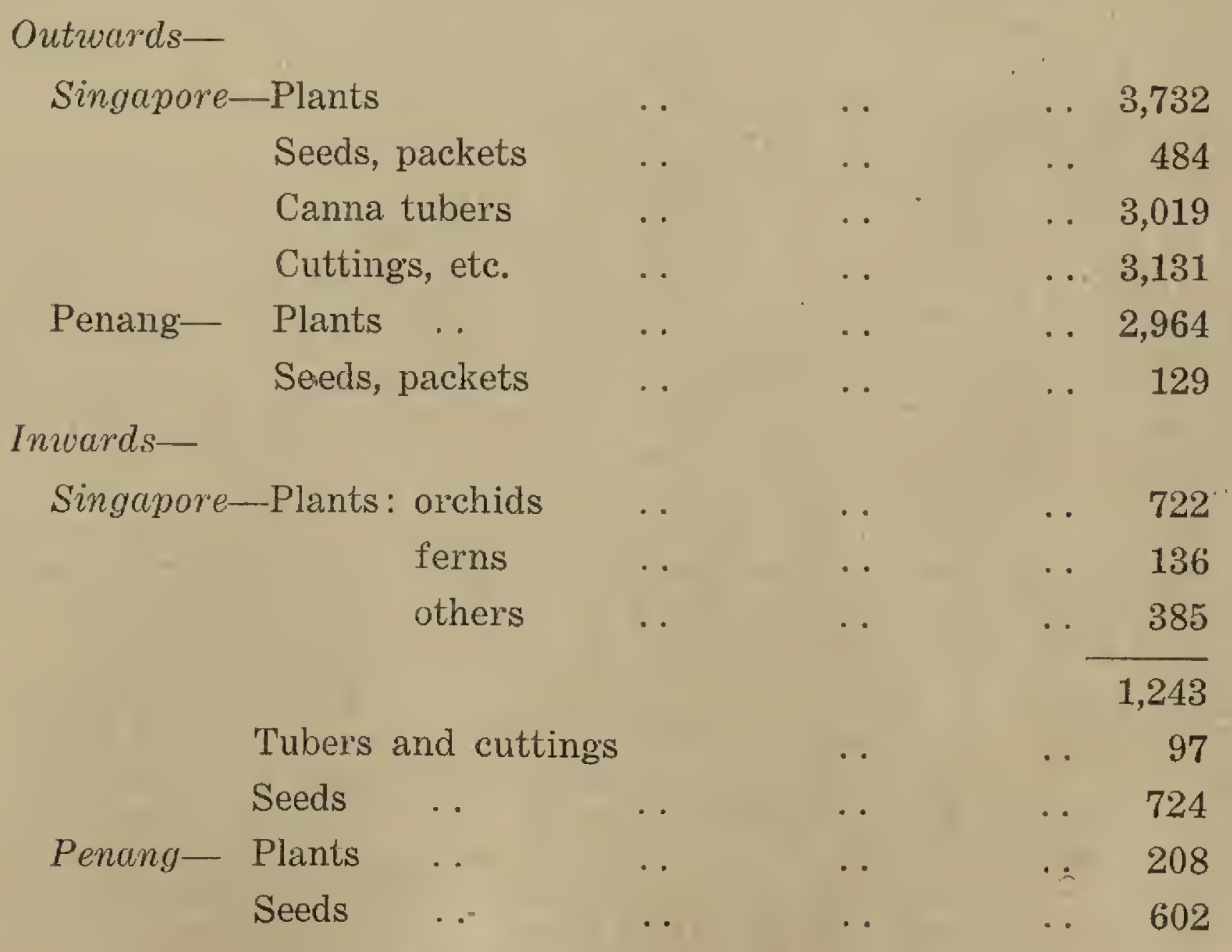


THE BOTANIC GARDENS, SINGAPORE

The Plant House--During the year a number of additional local epiphytic plants were placed in the plant house, including the ant-inhabited species Polypodium sinuosum, Hydnophytum formicarum, and Dischidia Rafflesiana; other epiphytes include a number of the common ferns of the genera Polypodium, Cyclophorus, Humata and Asplenium, and the flowering plants Aeschynanthus Wallichii, Medinilla Maingayi and another species, Pachycentria tuberosa and Hedychium longicornutum (the last two having fleshy water-storing roots). The following species of Nepenthes are now exhibited in the plant house: $N$. Rafflesiana, N. ampullaria, $N$. gracilis, N. Hookeriana, N. sanguinea, N. mirabilis, N. tentaculata; and also two artificial hybrids.

The collection of ferns was considerably increased during the year by the introduction of plants obtained on collecting expeditions in various parts of the Peninsula and in Borneo. It is difficult to grow some of the shade-loving species under the conditions prevailing in the plant houses, as there is insufficient shade and moisture, but many riverside species and some forest species have been successfully established. Plants of the genus Lindsaya seem to be particularly difficult to cultivate, though other ferns growing in similar natural conditions take quite kindly to pot culture. Plants of Osmunda javanica from the valley of the Sungei Sengam, below Cameron Highlands, made good growth and produced fertile fronds. Plants of Brainea insignis from Tanjong Selantai, Johore, were also successfully established. Among the ferns introduced from Borneo was Angiopteris horrida; a number" of others were not identified, and some are thought to be new species. The collection of Sielaginella plants was sorted out, and the species named (with the assistance of Mr. A. H. G. ALSTON, of the British Museum); a descriptive label was made for the group. The collection of maidenhair ferns was also properly sorted, and named as accurately as possible.

A good show of flowering orchids was maintained in the Plant House throughout the year. Some additions were also made to the classified group of local orchid species. Among other ornamental flowering plants, Oxalis dispar (open in the morning only) and Pentas coccinea made a good display, and a few of the more free-flowering Begonias were propagated to give additional colour.

In addition to the regular labelling of these plants by the embossing press, experiments were tried with descriptive labels. In the first place these were typed on cards about 4 by 6 inches, and the cards soaked in melted paraffin wax, or treated with a cellulose varnish (kindly supplied by the Government Analyst) to make them waterproof. In both cases the cards lasted about a month in good condition, after which they became gradually covered with a small black mould fungus; one card which was sheltered from rain lasted much longer. About October some sheets of white celluloid were acquired, and labels written on these with special ink have lasted very satisfactorily, showing no signs of mould after three months or more. By the use of these labels the visitor is given some information about the more interesting plants in the Plant House, and it is hoped that similar labels may also be made for some of the trees in the Gardens.

New Planting.-The following woody plants have been planted in the Gardens during the year: Attalea spectabilis, Artabotrys uncinnata, Bauhinia corymbosa, Berria ammonilla, Bombycidendron vidalianum, Calophyllum calaba, Casuarina quadrivalvis, Casuarina montana, Durunta repens, Eucalyptus longifolia, Erythrina monosperma, Garcinia xanthochymus, Garcinia Livingstonii, Heliocarpus americana, Jatropha curcas, Mangifera indica var. mekongensis, Mangifera Duperreana, Mangifera cochinchinensis, Pachira cyathophora, Phyllocarpus septentrionalis, Pterocarpus cambodianus, Pahudia rhomboidea, Rheedia madruno, Thevetic peruviana, Sophora tomentosa, and Sindora susa. A new plant of Ficus elastica was placed in the triangle near the foot of the lake, and grew well, after several other trees had been tried unsuccesfully. Two clove trees (Eugenia cayophyllata) were added to the group of spice plants on lawn $\mathrm{D}$, near the office.

New ornamental plants which have proved of value are the following: Ruellia malacosperma (a dwarf shrub with pretty lavender blue flowers open in the morning), Uroskinnera spectabilis, Hibiscus radiatus var. flore purpureo (large deep purple flowers), Cestrum nocturnum (fragrant flowers opening at 
dusk), Ipomoea "Baby Blue" (Peter Henderson), and a tall variety of Poinsettia which is common in Java but not often seen in Malaya. A small species of Senecio (?) introduced from Calcutta, proved a useful addition to the list of annuals which will seed freely in Singapore.

Interesting introductions.-Among the more interesting plants introduced during the year were Rheedia madruno, a fruit tree from Colombia; Phyllocarpus septentrionalis, a scarlet-flowered tree from Guatemala (presented by Dr. M. CARTHEW of Bangkok) ; Bulbophyllum Beccarii, an orchid with enormous leaves, from the Tambilan Islands (presented by Mr. VAN HAELEN); Alocasia cuprea, a beautiful aroid from Borneo; Dipladenia Brearleyana, a pink-flowered species, from Kuala Lumpur; and some new varieties of Plumeria from Honolulu.

General maintenance.-General maintenance of the Gardens proceieded as in former years. A trial was made of treating the more sloping paths with Colas, finishing with red gravel. This was found successful, and it is intended to treat ir the same way other paths which are at present subject to excessive surface wash during heavy rain. The lake was cleaned, and the Nymphaeas replanted, resulting in a greatly improved appearance. The three plants of Victoria regia flowered, and seeds were obtained from them. A low fence was placed along part of the edge of the Gardens Jungle, where the monkeys are usually fed, to protect the undergrowth, and a concrete curb along the opposite edge of the road to protect the grass edge. The monkeys have continued to do some damage, and it was found necessary to reduce their numbers somewhat by shooting. Some of the older ones were sometimes unpleasantiy aggressive in behaviour and it is hoped that these have been eliminated.

\section{THE WATERFALL GARDENS, PENANG}

The lawns in the Gardens were further improvod, especially in the upper part where extensive levelling and re-grassing was carried out, the work of general maintenance being assisted by the introduction of a motor mower, which cuts most of the grass in the lower part of the Gardens. A programme of manuring shrubs and small treies throughout the Gardens was completed; for this purpose, sludge from the Municipal sewage tank was found to be very effective. It is intended to make this an annual routine matter.

On lawn $\mathrm{K}$ a new terraced garden was made, and planting commenced before the end of the year. This garden is intended to accomodate climbing orchids of the Vanda teres type, terrestrial orchids (Spathoglottis, Arundina, etc.) and also succulents of the larger kinds. The edges of the terraces were built up with rubble walls, which will be planted with small flowering plants. The construction of this garden necessitated the removal of some trees, all of which are duplicated in other parts of the Gardens.

The upper section of the old nursery site was cleared, levelled and planted with grass. The hedges were improved, and a new hedge plantied to separate this section from the present nursery. It is proposed to make this area into a small enclosed garden, with paved paths and a formal arrangement of beds.

A number of shrubs and young trees were planted in various parts of the Gardens, chiefly with a view to adding colour. On lawn $\mathrm{E}$. all varieties of Bougainvillea are now represented, including the deep purple Maud Chuttleburgh (recently introduced from Singapore, where it has hitherto flowered very poorly). Other new planting included the following: Cycus revoluta, Antiaris toxicaria (the Upas tree, of which the old plant is dying), Castanosperum australe, nutmegs and cloves, and Podocarpus gracilior (tried as a hedge plant.).

Plant House No. 9 was completely rebuilt by the Public Works Department, in a style conforming with No. 8, with concrete posts and angle iron supports for the roof. The roof of Plant House No. 2 was strengthened, and half the roof on No. 10 was glazed. Other work carried out by the Public Works Department in the Gardens was as follows: a rubble drain was made in lawn $B$, from the outlet of the culvert under the road to the stream; the culvert at the bottom of the lily pond gully was re-conditioned and the outlet stepped; the quarantine house was altered to provide a garage for the motor mower; an expanded metal gate was fixed at the entrance to the nursery; a rubble apron 
was constructed on the rive: bank by Plant House No. 2. In addition to these works, the Gardens staff carried out extensive additions to roadside drains, constructed a new seedling house (roofed with "Windolite") and a petrol store. Twelve new garden seats were made up and brought into use.

The Bauhinia bidentata planted to cover the roof of House No. 3 flowered freely for the first time. It is a very handsome species. The plants of Grevillea robusta on lawn $V$ have made excellent growth. The two limestone balsams Impatiens mirabilis and I. tipusensis were successfully crossed, and seedlings raised. The seeds were sown on August 17th and did not germinate until October 20th.

Sunday performances by the Municipal Band were resumed in the Waterfall Gardens from July 26th. These proved so popular that additional performances are now given on Wednesdays. Special parking arrangements for cars during band performances were arranged by the Committee in consultation with the Chief Police Officer.

The Asst. Curator paid several visits to Anak Bukit Garden, Kedah; while on leave in December he also visited Kuala Lumpur Gardens, the Serdang Experimental Plantation, Fraser's Hill and the Sultan Idris College, Tanjong Malim. The Field Assistant visited the Malayan Agri-Horticultural Society's show at Kuala Lumpur, and at the same time went to the Serdang Plantation.

\section{GOVERNMENT HOUSE DOMAIN AND OTHER OUTSIDE CHARGES}

Singapore.-At Covernment House Domain, considerable attention was given to the question of grass cutting during the year, and by the use of additional machines (including two "bent-cutters") a great improvement in the general appearance of the Domain was effected. By the end of the year, all grass except that on steep banks and a few rough patches was being cut with machines, and lallang had been largely eradicated. Some uneven places were levelled, and this work will continue as fast as other necessary duties will permit. The Malay burial ground adjacent to Clemenceau Avenue was taken over by the Gardens staff during the year. Several old and unsightly trees were removed, the hedge by the roadside cleaned and replanted, some levelling carried out, and the area generally made tidy. A number of new trees were planted, some being interesting new introductions. Trees and shrubs were also planted in the area cut off from the Domain by Clemenceau Avenue, and additional trees in various parts of the Domain.

Advice was given to the Municipal Commissioners regarding the planting of roadside trees. Towards the end of the year Mr. LENNON made a special examination of all roadside trees, marking those which were dangerous or which for other reasons needed removing. An arrangement was made with the Municipal Commissioners for a regular examination of all trees by one of the Gardens officers, and the supervision of planting, pruning, etc., the Commissioners agreeing to pay to the Government the sum of $\$ 100 \mathrm{p.m}$. for this service from January 1st 1932.

Advice was given regarding planting of trees and other plants in the grounds of the following Government buildings, and plants supplied: The Labour Office, the Police Depôt, Flagstaff House, Telok Kurau English School, Bukit Panjang School, the College of Medicine, the General Hospital, the Raffles Museum and Library, the Opium packing factory. Plants of shrubs and trees were supplied for a number of new Government quarters. Advice about planting was also given to various private individuals and firms.

The Director was a member of a Committee appointed by $H$. E. the Governor to report on the possibilities of improving the appearance of the water catchment area surrounding the MacRitchie and Pierce Reservoirs. As a result, the Gardens Department undertook the responsibility of providing suitable trees and shrubs and the supervising of planting, the Municipal Water Engineer's staff carrying out the work. During the latter part of the year about 250 trees were planted along the borders of the MacRitchie Reservoir, in places where they will show to advantage; the majority of these are flowering trees. Further plans were made for planting in 1932.

Penang.-The usual inspections of and reports on, Municipal roadside trees and gardens were made. Considerable progress was made in the pruning of large trees, particularly the Angsanas. This work is very carefully done, and so far no fungus attack has resulted. 
Further improvements to the gardens at Bel Retiro and the other hill bungalows were carried out during the year. At Bel Retiro some of the flower beds were re-arranged, a new avenue of Cupressus macrocarpa and C. Knightiana was planted, and some new varieties of perennial Asters (brought in cold storage from England) were introduced. A new potting shed was erected and is a great improvement on the old one. The work of re-planning the garden at the Grag Hotel was continued, but was interrupted by landslips in various places. A further set of terraces was re-cut and grassed. A good show of flowers was maintained throughout the year. Some small improvements were carried out in the gardens at Bellevue, Convalescent and Fern Hill. At Woodside a low Bougainvillea hedge was planted between the house and the tennis court. At the request of the Assistant Curator, the Public Works Department made concrete beds round the base of the house walls; it is proposed to fill these with flowering plants, thereby obviating the necessity for so many pot plants. Work on the garden at the new bungalow of Hillside was begun in January, 1931. Lawns were planned and planted, a Bougainvillea hedge planted, and concrete beds made round the house, as at Woodside. At all the above bungalows separate potplant nurseries and beds for cut flowers have been established.

The Assistant Curator gave advice about planting in the grounds of various Government buildings, as follows: the P.\& P. W. V. C. Headquarters, St. George's School, Captain Kling Mosque, Tiger Hill Reservoir, Pulau Krah, various new quarters, and roadside trees by Green Lane and Tanjong Bunga Road. The Assistant Curator also visited and gave advice concerning planting at various Clubs, private compounds, etc.

R. E. HOLTTUM,

April 28th, 1932.

Director of Gardens, S. S. 



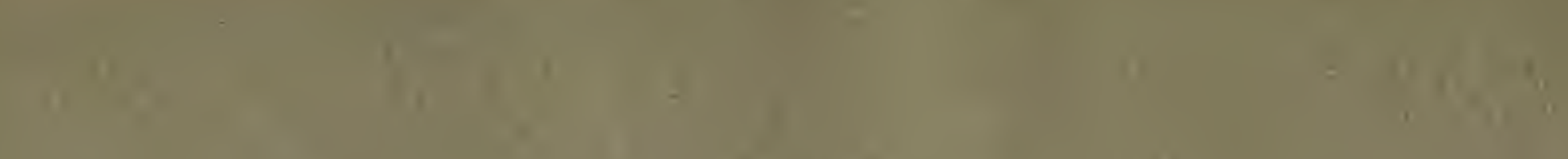

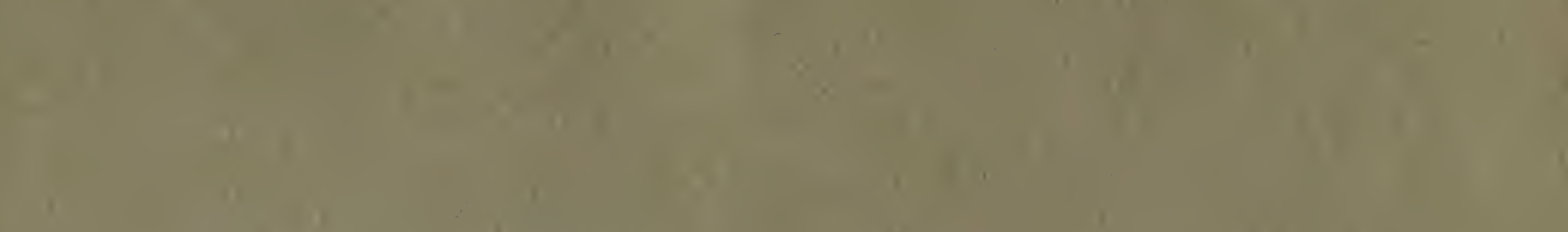

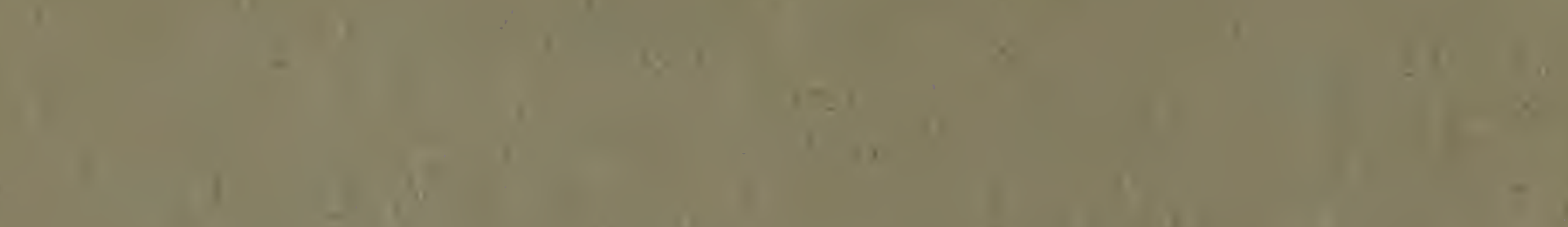

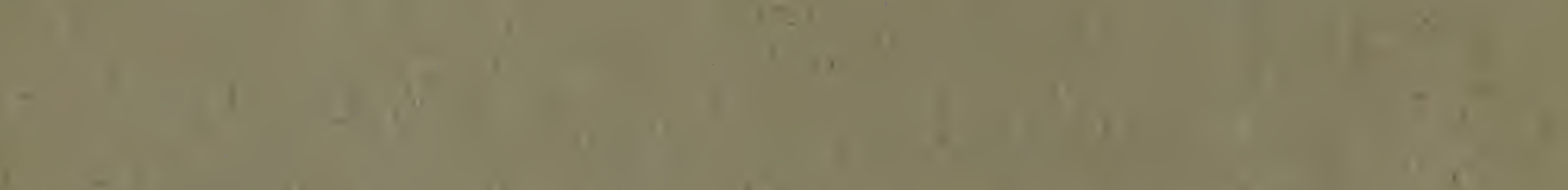

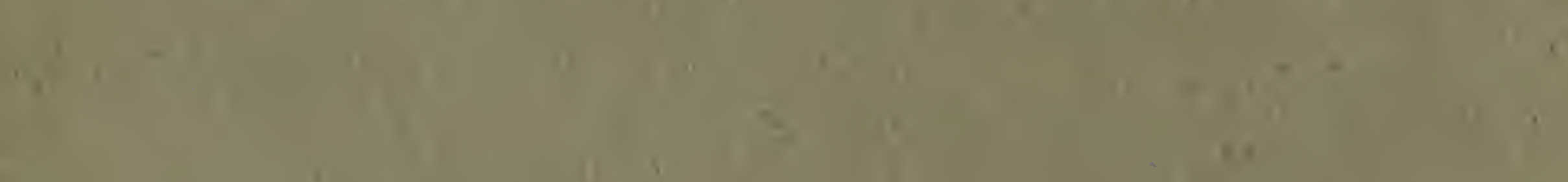

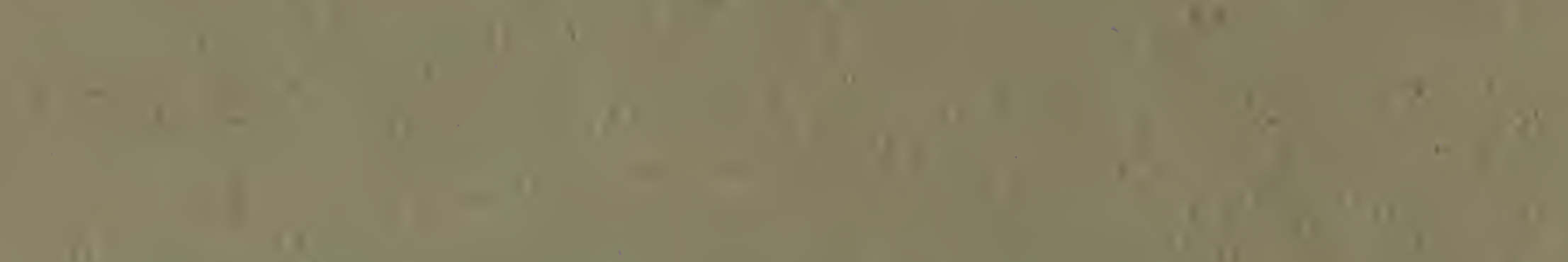

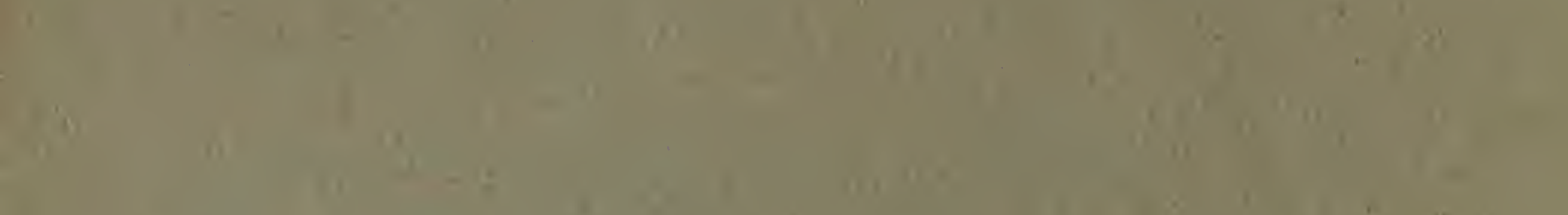

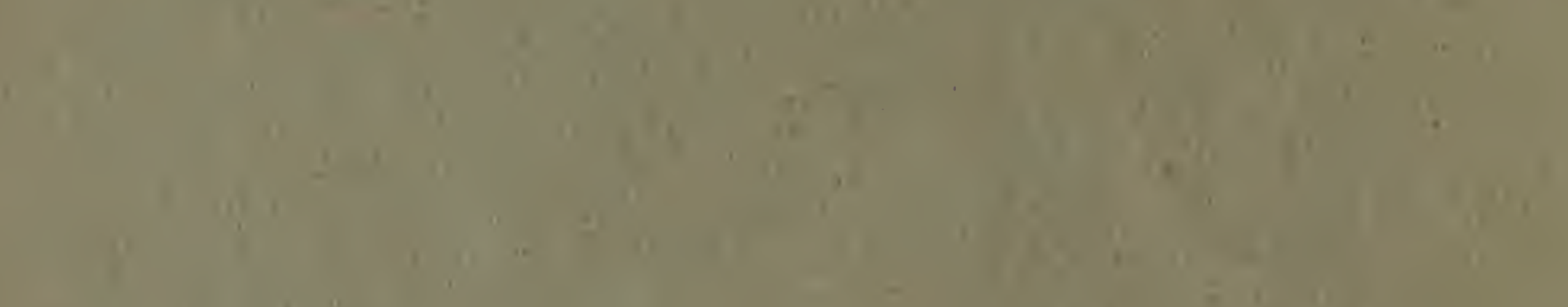

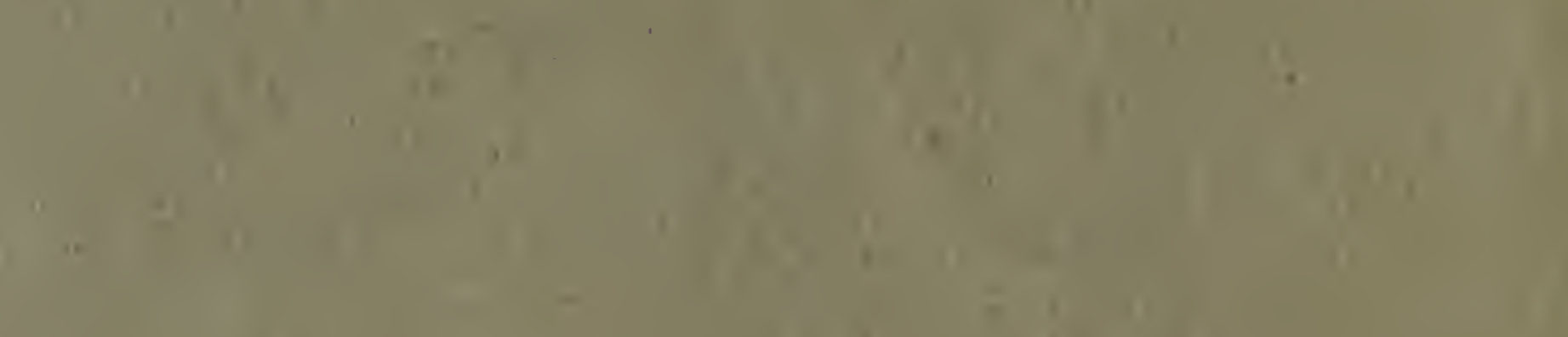

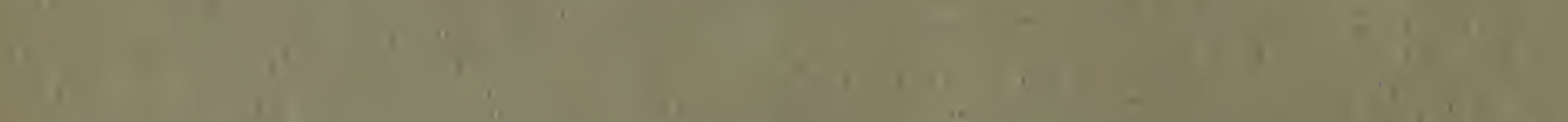
S.

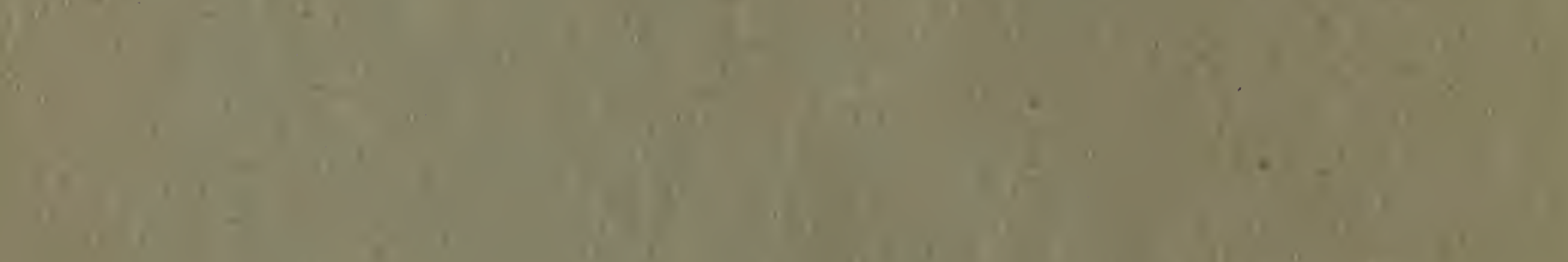

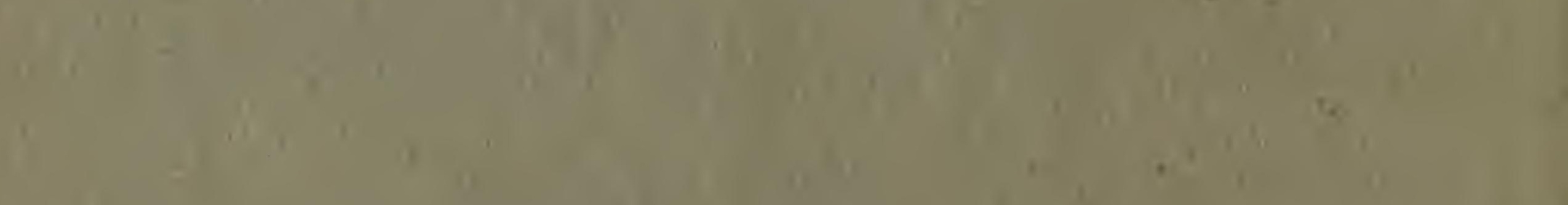

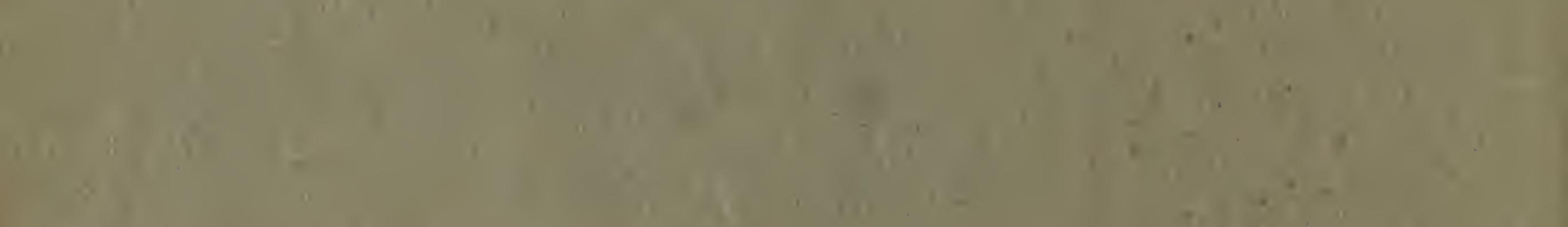

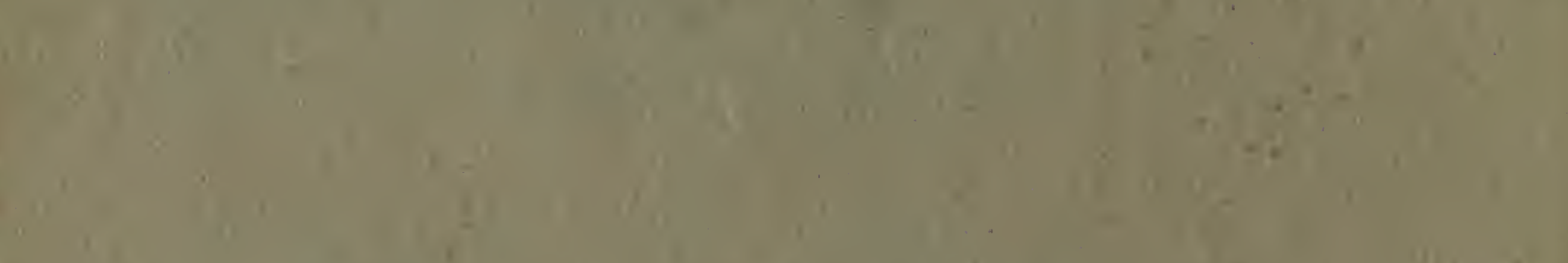

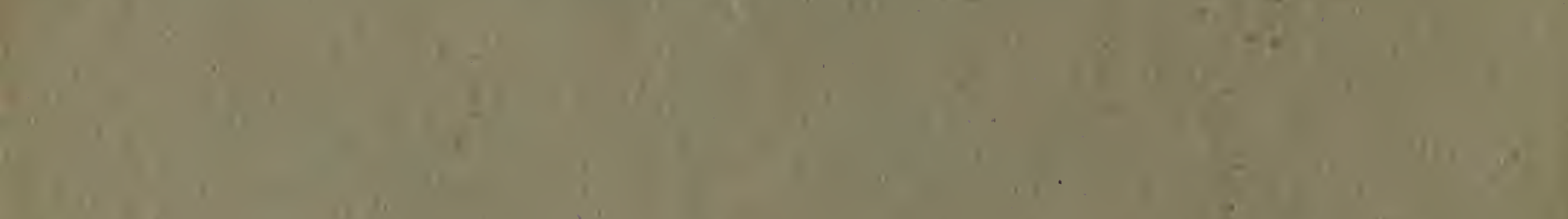
1

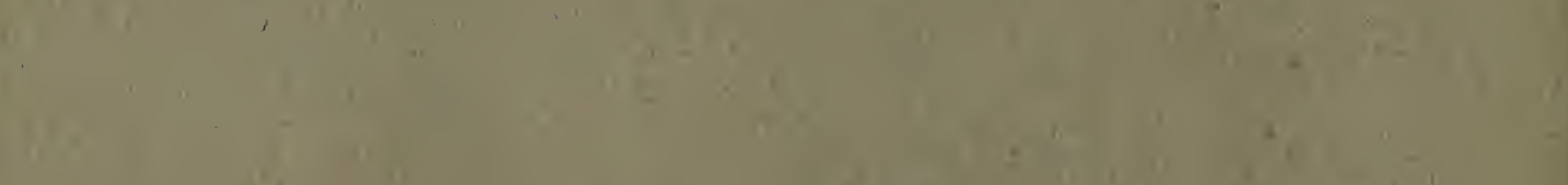

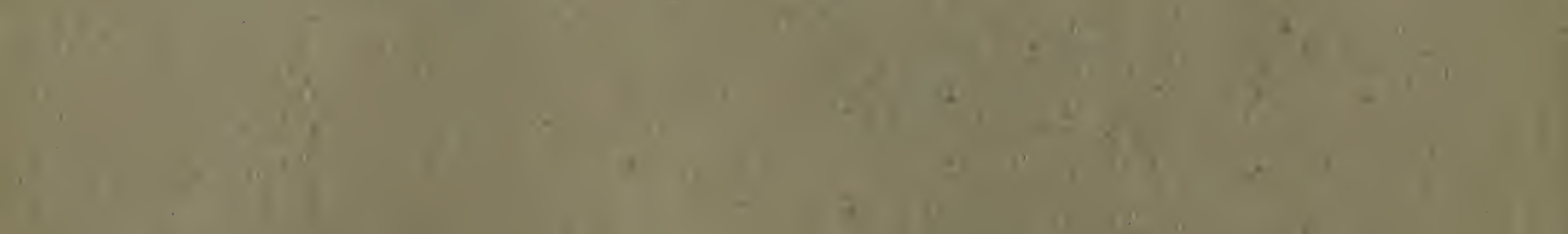
1
1
1 


\title{
STRAITS SETTLEMENTS
}

\author{
ANNUAL REPORT
}

OF THE

\section{DIRECTOR OF GARDENS}

FOR THE YEAR

\section{2}

BY

R. E. HOLTTUM

Director of Gardens, Straits Settlements

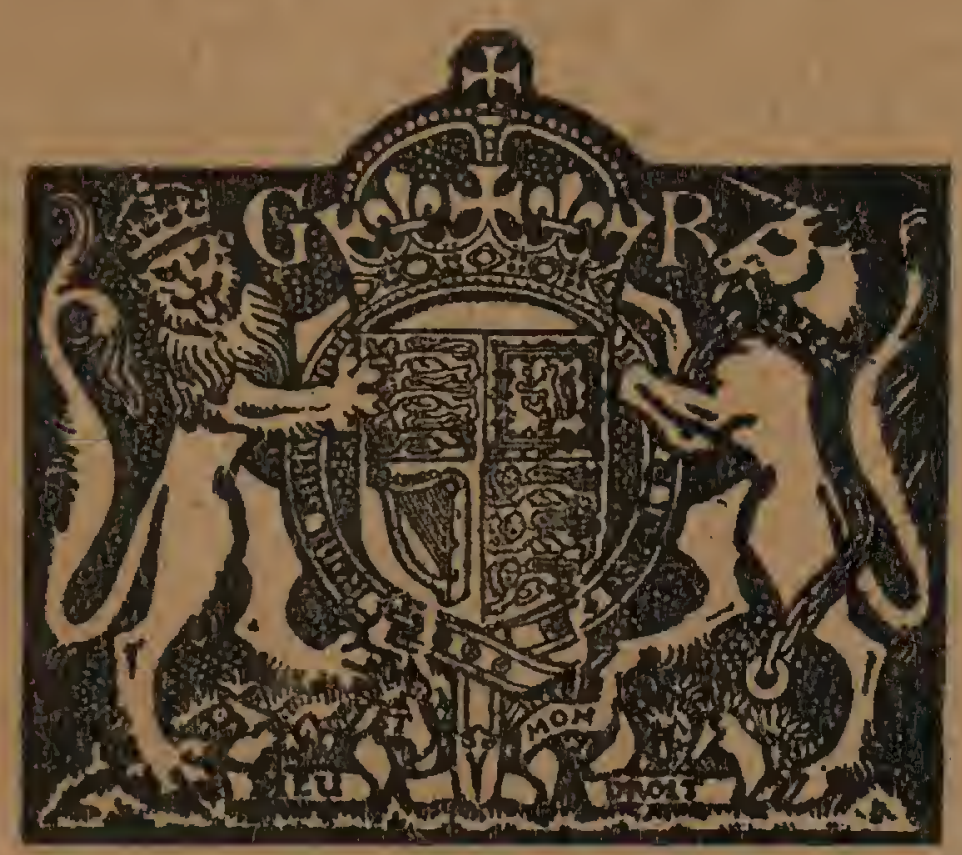

PUBLISHED BY AUTHORITY

SINGAPORE :

Printed at the Government Printing Office, Singapore

by V. C. G. Gatreld, Acting Government Printer 


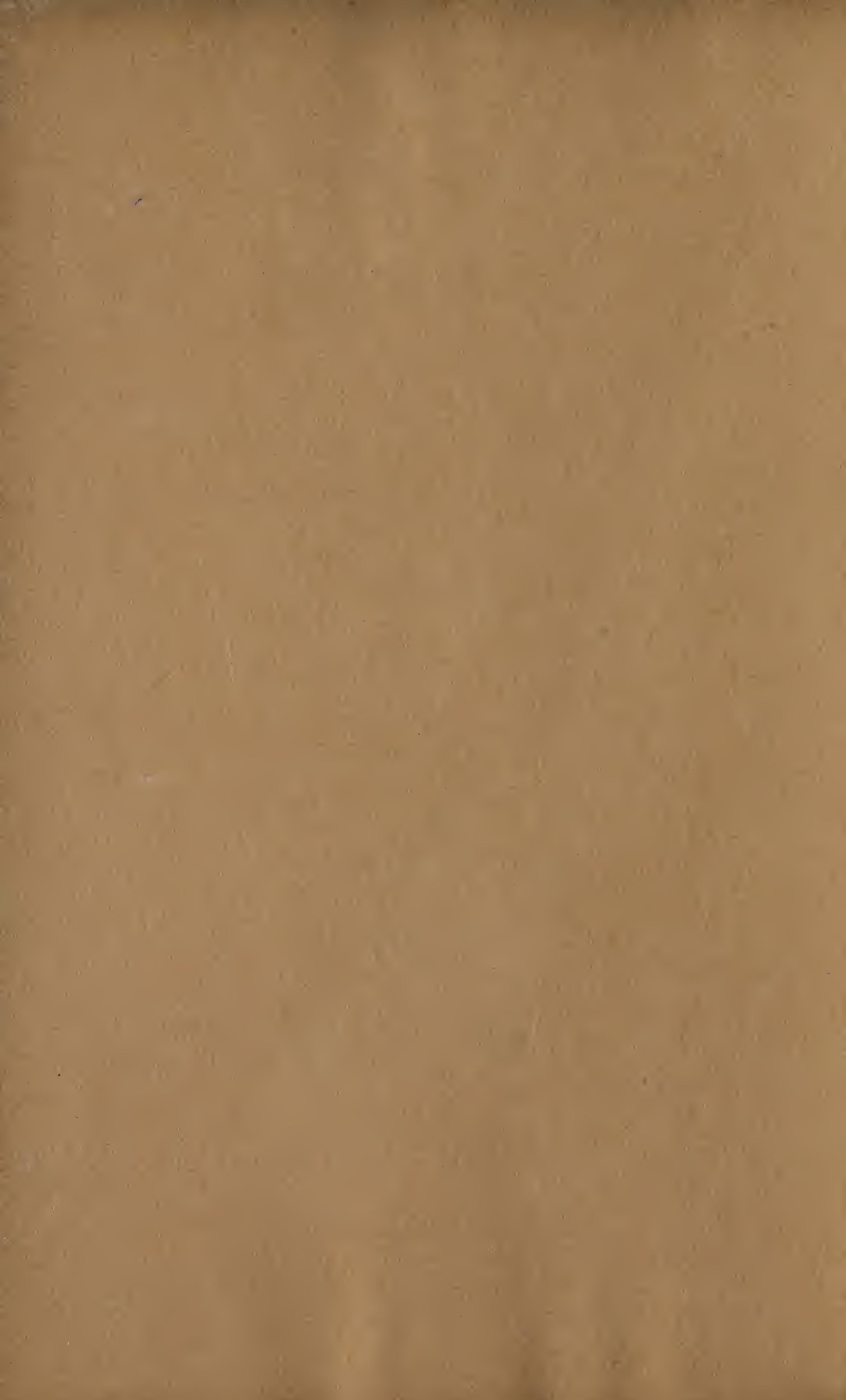




\section{ANNUAL REPORT OF THE DIRECTOR OF GARDENS, STRAITS SETTLEMENTS FOR THE. YEAR 1932}

\section{STAFF}

The Director was in charge throughout the year. Mr. M. R. HENDERSON was absent on leave (part of which was spent working in the Herbarium, Royal Botanic Gardens, Kew) until September. Mr. E. J. H. CorNer acted as Professor of Biology, King Edward VII College of Medicine until June 5th. The other members of the staff were on duty throughout the year.

The services of Enche MAT, Overseer, Waterfall Gardens, Penang, and GovinDASAMY, Overseer, Botanic Gardens, Singapore, were terminated, owing to abolition of their posts under retrenchment proposals, at the end of September.

\section{LABOUR}

The average number of gardeners and coolies employed in Singapore was 85 , in Penang 60 . Wages were reduced during the year to a minimum rate of 42 cents in Singapore and 45 cents in Penang. Hours of work in Singapore were changed from 6-30-11 A.M. and 1-5 P.M. to 6-30 A.M.-2-30 P.M. with the exception of necessary staff required for afternoon watering and other work in plant houses and potting yard.

\section{REVENUE}

The revenue from sales of plants was as follows:-

Singapore:-

Sale of plants

Inspection fees, etc.

Rents

(1)

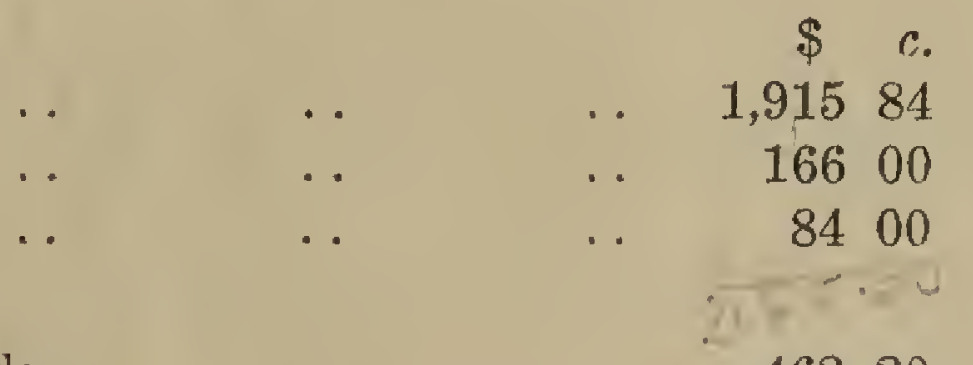

Sale of plants and seeds

Both in Singapore and Penang the Municipal Commissioners paid Government a sum of $\$ 100$ p.m. for the services of Gardens officers in connection with supervision of roadside trees and other Municipal planting.

\section{PLANT COLLECTIONS AND FIELD EXCURSIONS}

The principal field excursion during the year was undertaken by $\mathrm{Mr}$. C. X. FurTado, Assistant Botanist, who spent six weeks in British North Borneo, working in co-operation with the Clemens Expedition on Mt. Kinabalu, in March and April. Mr. FURTADo made a particular study of palms and aroids, of which groups he has a specialised knowledge, and gave general attention to other groups of plants. He was accompanied by KIAH BIN HAJI SALLEH, Plant Collector, who stayed two months assisting the expedition. In return for these services, specimens have been received from the expedition. Thanks are due to officers of the Government of British North Borneo for assistance rendered in making travelling arrangements for the Gardens officers to and from Kinabalu. 
Mr. E. J. H. CorNer made a joint expedition to the East Coast with Mr. W. Birtwistle, Officer-in-Charge of the Fisheries Department. For the first half of the trip they had the use of a launch provided by the District Officer, Kulantan, to whom grateful thanks are offered for this assistance. They were able to visit Pulau Tioman and other outlying islands, including P. Berhala, and to stop at several small villages on the Pahang coast. Mr. CoRNER took the opportunity of investigating the sand dune flora, especially the habitat of Casuarina equisitifolia, which colonises the large sand banks at the river mouths. P. Berhala also presented many points of ecological and botanical interest, and it is intended to write a special report of this part of the expedition. In Kemaman, Mr. BIRTwisTLE and Mr. CoRner were the guests of Mr. E. T. SwAN, who very kindly put his house at Bukit Kajang and his means of transport through the forest at their disposal. Mr. SwaN thereby showed the way to an extremely rich and almost unexplored botanical field, and our very best thanks are tendered to him, with the hope that another visit will be possible later. Mr. CORNER studied the riverside flora of the Kemaman and Nipa rivers for comparison with the Sedili in Johore, as well as provisicnally the immediate neighbourhood of Bukit Kajang, where several interesting plants were discovered, including a magnificent new species of Dysoxylon with very large fruits and a very floriferous new species of Puraboea. Mr. CoRner also collected a large number of fungi. About 400 numbered collections of plants were made in all.

Mr. CORNER also made a number of short excursions to southern Johore, especially to the Sedili river and its surrounding forest. On some of these visits he was accompanied by the Director and by Mr. C. E. CARR, whose expert knowledge of orchids was of great service in attempting to work out the peculiar flora of this region. Special attention is being given to the trees of the fresh water tidal swamp, and to the zonation along the river, and many species hitherto regarded as rare or unknown in the Peninsula have been found to be abundant in this area. During the latter part of the year Mr. CoRNer also took the opportunity of visiting one of the last remaining patches of swamp forest in Singapore (near the 15th mile, Jurong Road) as it is in process of being felled. This forest is as neax to being in a virgin condition as could be expected, and many of the species are the same as occur in the swamp forests of Johore. The possibility of studying each tree in detail as it is felled has enabled correlation to be made of characters of leaves and flowers with those of the base of the trunk, thereby giving valuable clues to the identification of standing trees in the Johore forests. Many of these trees have remarkable upwardgrowing roots and other curious growth habits, and no proper investigation of these has ever been made, largely owing to the difficulty of access to the swamp and to the greater difficulties of distinguishing the roots of one tree from another in the profusion of growth, and of finding criteria for distinguishing the trees in the field, where only the bases of their trurks are ordinarily accessible. Mr. CORNER through his energy and persistent efforts has made great progress in investigating these very interesting plants.

During the months July to September, one of the Gardens Plant Collectors was attached to the Oxford University Sarawak Expedition. In return for services so rendered, a set of specimens collected by the Expedition has been r,romised.

\section{HERBARIUM WORK AND OTHER INVESTIGATION}

During his absence on leave (which was extended for the purpose) Mr. HENDERSON spent the months of March, April and May working in the Herbarium of the Royal Botanic Gardens, Kew, studying critical material collected in recent years. A considerable number of new species and additions to the Peninsula Flora were discovered among this material, the most interesting being from Cameron's Highlands and from the limestone areas, to which Mr. HENDERSON has paid special attention in his collecting during the past few years. A number of specimens of recent collections by the Forest Department were also studied. The opportunity was taken to photograph Herbarium specimens of Malayan plants not represented in the Singapore Herbarium, and about 200 negatives were made. Thanks are due to the Director and staff at Kew, and to $\mathrm{Mr}$. H. N. RIDLEY and Mr. I. H. BURKILL for their interest and help. After his return to Singapore, Mr. HENDERsoN prepared a paper embodying part of the results of his work at Kew, and it is hoped to publish this early in 1933. 
During Mr. Henderson's absence, Mr. C. X. FurTado had charge of the herbarium in Singapore, and carried out the usual routine work. During the year a beginning was made in the arrangement of all non-Peninsular specimens in proper order. Mr. FURTADo spent much time working with the herbarium of cultivated plants, and devoted study specially to palms, both in the general and gardens herbarium. Mr. FURTADo also began an index of references to Peninsula plants not mentioned in Mr. RIDLEY's Flora. The number of sheets mounted and laid in during the year was 5,734. Of these 2,292 were from institutions outside the Peninsula, 726 were of plants cultivated in the Gardens, and 2,716 were of plants collected in the Peninsula, about half of them being duplicates received from the Forest Research Institute, Kepong. Thanks are due to Mr. C. E. CARR, Dr. A. S. HITCHCOCK, and to the staffs of the herbaria at Kew and Buitenzorg for help in identification of critical and doubtful plants; and to the Botanic Gardens at Calcutta and Buitenzorg and the Bureau of Science, Manila, for the loan of specimens.

Mr. CORNER studied the Malayan species of Ficus, of the subgenera Covellia and Neomorphe, making a careful investigation of their flowers. This work has added four new records and one new species to the Flora of the Peninsula. The results will be published in 1933. A collection, preserved in alcohol, of the receptacles of the Malayan species of Ficus has been started for general use.

Mr. C. E. CARR spent a good deal of time working in the herbarium on Malayan orchids, partly on his own collections and partly on those in the Gardens herbarium, and prepared a paper for publication in which 25 new species were described.

The following duplicate herbarium specimens were sent out:-

Royal Botanic Gardens, Kew. . . . . . 545

Dr. E. D. Merrili, New York . . $\quad \ldots \quad \ldots 382$

Botanic Gardens, Buitenzorg $\quad \ldots \quad \ldots \quad \ldots \quad \ldots 343$

Dr. CHRISTENSEN (ferns) $\quad \ldots \quad \ldots \quad \ldots \quad \ldots 312$

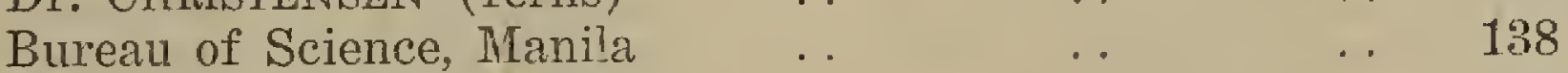

Mr. H. N. DiXoN (mosses) _. $\quad \ldots . \quad \ldots \quad \ldots 124$

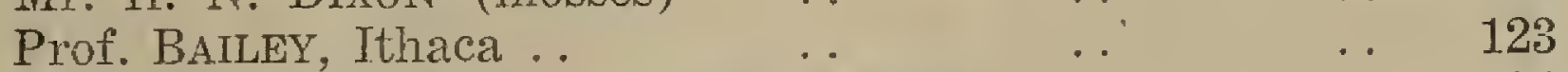

Forest Research Institute, Kuala Lumpur . . $\quad$. . 104

Ministry of Commerce and Communications, Bangkok .. 86

Arnold Arboretum, U. S. A. .. $\quad \ldots \quad \ldots .75$

Mr. W. E. NICHOLSON (Liverworts) $\quad \ldots .46$

Dr. HitchCock, U. S. A. (grasses) $\quad \ldots . \quad \ldots \quad 38$

Dr. M. BURRETT _. .

$\begin{array}{lllll}\text { Dr. PUlle } & \ldots & \ldots & \ldots & \\ \text { Nam } & \ldots & \ldots & \end{array}$

Named fungi to various institutions $\quad \ldots \quad \ldots 326$

Total . 2,654

Hand timber specimens were distributed as follows:-

Forest Research Institute, Kuala Lumpur _. $\quad$. . 7

Bureau of Science, Manila $\quad \cdots \quad \cdots \quad$ Total $\cdots \frac{1}{8}$

Specimens lent for study to other institutions and specialists were as follows :

Dr. DANSER (Umbelliferæ, Cornaceæ, Loranthaceæ) . 416

Dr. HUBERT WINKLER (Urticaceæ) . . . 323

Dr. FoXWORTHY (Dipterocarpacer) $\quad$. . $\quad$.. 159

Prof CRAIB (Siamese plants) .. . . . 64

Mr. I H. BuRkILL (Ilex, Sapium, Dioscorea, Sanseviera) 35

Dr. Pulie (Evolvulus) _. $\quad \ldots . \quad \ldots \quad 21$

Dr. CHRISTOPHERSEN (Joinvillea) . $\quad \ldots .12$

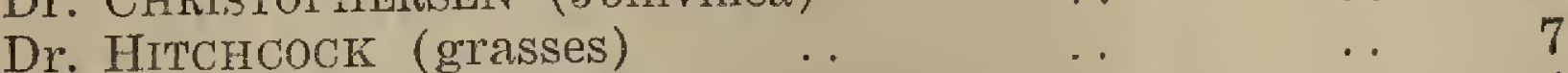

Royal Botanic Gardens, Kew . . $\quad \ldots \ldots$

Botanic Gardens, Buitenzorg _. $\quad \ldots \quad \ldots$.

Total .. 1,043 
Specimens were received in exchange from the following:-

Forest Research Institute, Kuala Lumpur.

Arnold Arboretum, U. S. A.

Metropolitan Museum of Natural History, Nanking, China.

University of California.

Dr. E. D. MerriLl, New York.

Botanic Gardens, Buitenzorg.

Government Botanist, Brisbane.

Smithsonian Institution, U. S. A:

Bureau of Science, Manila.

Dr. KERR, Bangkok.

Royal Botanic Gardens, Kew.

Taihoku Imperial University, Japan.

The Cryptogamic Herbarium.-Mr. CoRNer devoted much of his time to the continuation of his fungus studies, particularly to the structure and systematy of the Polyporaceæ, and published three papers on the subject during the year. In connection with this work, about 50 specimens were borrowed from the herbaria at Buitenzorg, Manila and Peradeniya. The common agaric, Collybia apalosarca, was also investigated in detail and the results have been sent for publication; it is interesting because it closely unites the two common European species C. radicata and Armillaria mucida, and throws considerable light on the classification of agarics. Several collections of fungi were received from the Department of Agriculture and from the Rubber Research Institute for identification.

Mr. CORNER has also continued his observations on the development of fungi. The wooden insect proof "fungarium" constructed in 1931 was in full use, and 32 species of Polypores have been grown successfully to maturity. With the experience gained, it is hoped to build a more durable house in which other plants requiring very damp conditions can also be grown.

The Director continued to work on Malayan ferns. The early part of the year was devoted to completing a study of the interesting groups of climbing ferns hitherto united under the genus Stenochlaena and a paper on the subject was published. In the course of this work, a considerable amount of information was obtained concerning the anatomy, morphology, and biology of the plants concerned, leading to a revision of ideas on their relationship. The Director also worked over his collections of ferns from Kinabalu, submitting a set of them to Dr. C. CHRISTENSEN of Copenhagen for his opinion. The collection proved to contain about 30 new species and a considerable number of others not previously reported from Borneo. It is hoped to publish an account of these in 1933. An attempt was also made to study the species and varieties of Adiantum (maidenhair ferns) in cultivation, and some progress was made, with a view to writing a popular account of the group.

Mr. H. N. Dixon reported on the Kinabalu mosses, which proved also to be very interesting. There were nearly 20 new species, one representing a genus hitherto only known from the African tropics and one being an Andreaea, of which no species were previously known in Asia south of the Himalayas.

Laboratory Work.-During July and August, Mr. R. HiLl, of the School of Biochemistry, Cambridge, worked in the laboratory and made preliminary experiments on the natural dyes in Morinda spp., Vitex spp., various members of the Rhizophoraceæ, and several other plants. With Mr. CoRNER'S assistance, he obtained locally the dried bark of several species with which to continue his researches in England.

The Director continued his cultivation of hybrid orchid seedlings on sterile media, and a considerable number of new sowings were made, both from crosses made in the Gardens and from outside, the latter principally made by Mr. J. LAYCOCK, who has taken a great interest in this work. Some of the oldest Vanda and Arachnis seedlings were planted out under normal conditions of cultivation during the year, and the largest reached more than a foot in height and an almost full development of leaf and stem size. It is hoped that they will fiower in 1933. Much difficulty is still encountered in establishing the seedlings on normal substrata after they leave the culture flasks. A report on this work was given in the second number of the Malayan Orchid Review, and further reports will be made in the same publication. 


\section{PUBLICATIONS}

Three issues of the Gardens Bulletin were published during the year. Vol. V, Nos. 9-11 consisted of Mr. HoLTTum's paper on Stenochlæna, Lomariopsis and Teratophyllum in the Malayan Region (pp. 245-312, and 12 plates). Vol. $V$, No. 12 contained a paper by Mr. CORNER on the identification of the Brownroot Fungus (pp. 317-350). Volume VI, consisting of papers on plants used medicinally in the Malay Peninsula, having already been completed concurrently with Vol. V, the next issue to appear was Vol. VII, part 1, containing two papers on orchids by Mr. C. E. CARR, the first describing one new genus and 25 new species, and the second dealing with the genus Trniophyllum in the Malay Peninsula. Twelve new species of this group of minute leafless orchids were described, and all fully illustrated.

In addition to the above, a paper by Mr. CORNER on the structure and development of Polystictus xanthopus was published in the Annals of Botany, and another on Fomes levigatus and allied species in the Transactions of the British Mycological Society.

Towards the close of the year the Director was asked whether he would edit the Horticultural section of a proposed quarterly publication of the Malayan Agri-horticultural Association. This was arranged, and short articles were submitted for the first issue, to appear in January 1933, prepared by the Director and Mr. FLIPPANCE. It is hoped that this publication will be the means of bringing to public notice activities of the Gardens Department which are of general interest, and that in it may be published information in popular form about plants and their culture; hitherto there has been no publication in which articles could be issued.

\section{PLANTS OUTWARDS AND INWARDS}

Gifts are gratefully acknowledged from the following:

Mrs. Clemens, Mr. Choa Eng Wan, Mr. J. A. le Doux, L. A. Dreygus Co., Mr. Glineur, Mr. van Haelen, Dr. G. A. C. Herklots, Mr. J. M. Jackson, Mr. H. L. Jeppesen, Mr. J. Laycock, Mr. Lee Peck Hoon,'Mr. B. K. SAHeb, Mr. W. N. C. Steele, Mr. Sterneerg, Mr. Tan Boon Teck.

Orchids and other plants were exchanged with Mr. B. A. LowE, Mr. M. A. Brooke, Mr. NG Cinee Seng, Mr. J. E. Zurower'z, Mr. Xunlong, the AgriHorticultural Society of Madras and the Chandra Nursery. Seeds were received as exchanges from 19 institutions in different parts of the world, and despatched to 30 institutions. At Singapore 744 plants and 1,195 cuttings were supplied for Government buildings, etc.

Plants outwards-

\begin{tabular}{|c|c|c|}
\hline \multicolumn{3}{|c|}{ Singapore-Plants } \\
\hline & Cuttings, tubers, etc. & 3,522 \\
\hline & Seeds & 338 packets \\
\hline \multirow[t]{6}{*}{ Penang- } & Plants sold & 2,411 \\
\hline & Seeds sold & 16 packets \\
\hline & Plants supplied to Municipality & 93 \\
\hline & Plants supplied to Government & 52 \\
\hline & Plants supplied on exchange & 289 \\
\hline & Seeds supplied on exchange & 16 packets \\
\hline
\end{tabular}

Plants inwards-

Singapore-Plants collected by Gardens staff $\quad \ldots \quad 192$

Plants purchased _. $\quad$.. 147

Plants received as exchanges or gifts . . 344

Seeds purchased _. $\quad$. 248 packets

Seeds received as exchanges or gifts .. 156

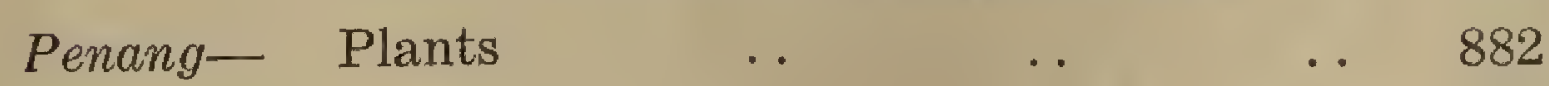

$\begin{array}{lllll}\text { Seeds } & \ldots & \ldots & & \end{array}$ 


\section{THE BOTANIC GARDENS, SINGAPORE}

The Plant House.-The arrangement and labelling of groups of plants was continued, and by the end of the year descriptive labels had been provided for the following groups: Aroids (two labels), Zingiberacex, Marantaceæ, Musaceæ, Dracæna, Asparagus, Cyclanthaceæ, Cycadaces, Conifers, Tacca, Malayan ferms, Adiantum (maidenhair ferns), Succulents, Lycopodium, Epiphytic ferns, and a few labels for special plants. These labels are written with special ink on sheets of white celluloid, and prove very satisfactory. The ink tends to fade in a strong light, but in shady places lasts in good. condition for several months. Simple metal sheaths are used to support the labels. Individual plants are labelled as before with embossed aluminium labels. Some trouble was experienced owing to corroding of these labels in the moist and shady parts of the plant house. It is hoped that this trouble has been overcome by the use of aluminium (instead of brass) tacks and screws to attach the labels to their wooden supports; these were obtained through the courtesy of Messr's. Diethelm \& Co.

Additions were made to the collection of local epiphytes in the plant house, and a very interesting set of these plants is now on show, including seven species of Dischidia, Myrmecodia tuberosa, Cyrtandra suffruticosa, Ficus diversifolia, Schefflera spp., and a number of ferns and other plants previously reported. One exhibit consists of a black termites' nest, removed from a tree overhanging the Sedili river, which has growing from it several different epiphytes; the termites were not disturbed in the removal of the nest, and continue their activities. Numerous additions were made to the special series of local orchid plants in the small house.

An attempt has been made to cultivate some of the Malayan species of Didymocarpus and allied genera which are among the few local ornamental fiowering herbaceous plants. Many of these are very difficult to grow under artificial conditions, but a few have been found to respond to pot culture, including a very fine new species of Parabcea brought from Kemaman by Mr. CoRNER. Didymocarpus kompsoboed, with pure white flowers, has also grown and flowered well, and the faintly pink $D$. platypus, but plants of $D$. quinquevulnera, after surviving for a few months, gradually died. It appears that these plants have particular soil requirements, and the management of correct watering is also a difficulty.

Improvements were made to the steps in front of the plant house enabling a more effective use of them to be made for the display of flowering plants in pots, and a set of large square concrete pots was made from a design by Mrs. HouTTum. These large concrete pots contain conifers, which give a pleasing break in the continuity of the flowering plants. Under Mr. LENNoN's care, a good display was maintained on the steps throughout the year. Potted plants of Bougainvillea Mrs. BuTT proved most useful in adding brilliance to the colour scheme. At the foot of the steps, on the side of the road facing the Plant House, two shallow concrete tanks were made for cultivation of Nelumbium, Eichornea, and other sun-loving water plants which cannot conveniently be grown in the lake. These tanks, with a paved section at each end, finish off the foot of the steps more effectively than has hitherto been possible, and the scheme has been continued as a raised side table opposite the whole length of the plant house, with paved sections to support pot plants. The varieties of Spathoglottis are displayed in this section.

Notes on plants of interest.-The most interesting acquisition during the year was seeds and plants of the remarkable Kinabalu plant Scyphostegia borneensis (which will probably be made the type of a new plant family), presented by Mrs. Clemens. Two plants brought over by Mrs. Clemens have survived, and sixteen seedlings have been raised. This is presumably the first time Scyphostegia has ever been brought into cultivation, and it is to be hoped that the plants may grow to maturity so that easily accessible material may be available for study. The Siamese Afgekia sericea continued to flower freely and almost continuously, and produced seeds for the first time. This is a valuable addition to our ornamental climbers. Pentas coccinea was used successfully as a bedding plant and flowered freely and continuously. Luntana Sellowiana is a very useful creeping or climbing plant, flowering freely, in habit very like a Verbena. Lankesteria Barteri, a slender shrub recently introduced from Kew, flowered well once. It is not a strong-growing plant at present, and it seems likely to be seasonal in flowering. Scutellaria costaricana, 
also recently introduced from Kew, flowered once, and made slow growth. It appears to stand a sunny position. Tumera curantiaca flowered freely; like the other species of its genus, its flower's fade in the afternoon. Tussacia pulchella proved a hardy bedding plant, but is not very decorative. Cestrum diurnum, recently introduced from Washington, began to flower and grew strongly. Passiflora bicapsularis v. acutiloba flowered well, and fruited. Clove plants were added to the group of spice plants near the office.

New Planting. - The following woody species were planted out during the year: Areca concinna, Bauhinia malabarica, Bauhinia binata, Bougainvillea Mrs. Fraser, Canarium luzonicum, Cestrum diumum, Coccothrinax argentea, Connarus grandis, Dillenia sp. (Tembeling), Erythrina lithosperma, Erythropsis fulgens, Jacaranda acutifolia, Kigelia pinnata, Jatropha gossypifolia, Lankesteria Barteri, Melaleuca styphelioides, Mimusops Kanki, Ormosia calavensis, several additional varieties of Plumeria, Pterocymbium inctoria, Sapium sebiferum, Scutellaria costaricana, Semecarpus vernicifena, Taraktogenos subintegra, Tarahtogenos Blumei, Turnera aurantiaca, Veitchia sp.

In addition to the above, a selection of small conifers, mostly of uncertain identity, was planted on lawn D (in place of Rhopaloblaste palms), and it is intended to add to this group. Among them are three species or varieties which have lately been very much propagated as pot plants by local Chinese gardeners; the origin of these is uncertain, and it is difficult to identity them. In addition, plants raised from seeds of Cupressus macrocarpa and C. Knightiana trom Peradeniya have been planted, and have made good growth.

Losses.-One of the old oil palms (Elaeis guineensis) planted about 1890 on the bandstand hill died during the year and was replaced by a plant of Coelococcus carolinensis. The old Calophyllum inophyllum by the Lower Ring Road had to be removed owing to rot at the base which caused the fall of a large branch. Two trees of Araucaria Cunninghami were also lost, only one now remaining of the former row near the office; also one Cassia grandis, and a large Albizzia by the Nursery.

The Lake.-Two seedlings of Victoria regia, raised from our own seeds, were planted during the year, and at the edge of the lake clumps of Cyperus papyrus (the Egyptian papyrus) and a species of Typha, presented by Mr. LEE PECK HOON.

Fencing.-A wire fence, with concrete posts, was erected along the Gardens boundary in Dalvey Road.

Buildings.-The roof of the Store was renewed by the Public Works Department, and the timber of the large Plant House repaired. The potting shed, and the old Javanese quarters, were remroofed by Gardens labour.

\section{WATERFALL GARDENS, PENANG}

Grass.-In addition to normal maintenance, improvements to the grass areas were effected by filling, levelling and turfing near the entrance and on lawns $\mathrm{E}, \mathrm{F} \& \mathrm{M}$; on lawn $\mathrm{E}$ it was necessary to blast and remove a number of rocks before levelling could be effected. The result has been to extend considerably the area cut by mowing machines, and to effect a corresponding improvement in the appearance of the upper part of the Gardens.

The orchid-succulent garden.-The planting of this section of lawn $\mathrm{K}$ was almost completed, the following plants being arranged on a series of terraces: the climbing species of Vanda and Arachnis, the common species of Arandina and Spathoglottis, and all available species of Agave, Aloe, and Oprontia, Cereus, Sanseviera, Yucca and Pitcairnia. The granite walls which support the faces of the terraces were planted with Verbena, Portulaca, Coreopsis and other flowering plants, which add much to the decorative value of the scheme. Small paths and steps give access to all the terraces.

The lily-pond gully.-The path on the east side was reduced to eight feet in width. The additional planting area thus obtained was marked off by an irregular line of rocks. The area was raised by the addition of soil from the drainage work on the other side of the path, and planted with a variety of large foliage plants. 
Lawn $M$, at the head of the Gardens, was partially cleared of superfluous trees, the rubbish pit moved further back, and the area prepared to bear a collection of trees of the genus Ficus.

Conifers.-It is intended to add to the collection of these plants on lawn $\mathrm{F}$, and, with a view to this, several superfluous trees of Eugenia were removed and the area levelled.

Enclosed garden on lawn $V$. This area was taken in hand, and a scheme for its development prepared. As a first step a concrete tank 30 by 18 feet, with inlet and outlet pipes, was constructed, to display the finer kinds of water lilies. Material for laying paved paths was also prepared.

New planting of trees and shrubs. - A number of additional flowering trees and shrubs were planted on lawns A, E, H, S \& T. The collection of Cassia spp. on lawn $O$ was increased by the addition of $C$. grandis and $C$. nodosa. In the fern rockery a number of additional tree ferms were added. On lawn $\mathrm{S}$ a group of less well-known small trees añd shrubs was planted.

Buildings and masonry.-Repairs to the roof of plant houses Nos. 6 \& 7 and of the potting shed were carried out by the Gardens staff. The centre stagings of plant house No. 10 were enlarged by two feet and the surfaces of all stages re-sloped with cement; also the central water tank was opened and the inflow and outflow altered. New hand rails were fixed on the lily pond bridges. Twelve new garden seats were fitted and all the old ones repainted; there are now 23 seats in various parts of the Gardens. The workshop fittings were added to, and all the tools ordinarily required for the mowing machine are now installed.

The Public Works Department constructed a new outlet for the lily pond, and repairs to retaining walls and bridges necessitated by the heavy rain on the night of November 24th.

The Gardens staff carried out the following works: a stream was dammed, supply pipe laid, and a concrete tank constructed to provide water for the new orchid and succulent garden; new rubble drains were made by the eastern approach to the lily pond and on lawn S; and a glazed semicircular invert drain was constructed near the north bridge.

\section{GOVERNMENT HOUSE DOMAIN AND OTHER OUTSIDE CHARGES}

\section{Singapore-}

Government House Domain.-.The usual routine work was carried on as in past years. A large uneven area on the slope to the south of Government house was levelled and re-grassed, and some levelling was also done at the mouth of the gully in the lower part of the Domain. A number of new trees were ulanted, chiefly near the boundaries of the Domain, and some additional ormamental shrubs for screening purposes. Several old trees were removed.

Municipality.-Mr. LENNON made regular inspections of roadside trees for the Municipal Commissioners, and supervised planting, pruning and felling. 411 trees and 40 shrubs were planted during the year, and 174 old trees felled.

The supervision of tree planting at the MacRitchie Reservoir was continued, and about 160 trees were planted during the year. In addition, an experimental planting of about 600 fast growing trees was made in poor secondary jungle near the Pierce Reservoir; it is hoped that later good forest trees may be able to grow under the shade of the trees now planted.

other Work.-Advice was given concerning planting and pruning of trees and shrubs, tennis courts, and other matters, for the Public Works Department, the Y. W. C. A., St. Andrew's Cathedral, H. M. Naval Base and the Banque de l'Indochine. Trees were supplied to the Public Works Department for Mount Pleasant Road, and trees and shrubs for various new compounds.

\section{Penang-}

The gardens at Bel Retiro, Strawberry Hill, the Crag Hotel and the five Government hill bungalows were in charge of the Department throughout the year. At Bel Petiro 130 Cypress trees were planted, of the species C. macrocarpa and C. Knightiana; these were raised from seeds obtained from Ceylon in August 1930. By the end of 1932 the largest plants had attained 10 feet in height. Thirty Cypresses were also planted on Strawberry Hill to 
replace the Dacrydium trees which are in poor condition owing to severe cutting of the roots when the terraces were made. Cypress trees were also planted in other places on the hill, the total number being 208 .

Considerable work was done at the Crag Hotel, and good progress made with the re-designing of the garden. The most important new work was the re-terracing of the slopes at the entrance to the hotel grounds; these slopes have long been very unsightly, but it has not been possible to deal with them previously. A complete clearance of all secondary jungle and planting of more Bougainvillea and other flowering shrubs below the dining room block was carried out.

At Woodside and Hillside the new wall beds round the houses were brought into use and have proved most effective; a reduction in the number of pot plants has been possible in consequence.

- In the rural area of the Island, 78 roadside trees were supplied and planted in Green Lane and at Tanjong Bunga. Trees in the neighbourhood of Senoy Lines were reported on, and their pruning supervised. A plan for planting the compound at the new Trade School was prepared and plants supplied. Advice was given about planting and general maintenance of grounds at the Residency, St. George's Church and Captain Kling Mosque.

The Municipal roadside trees were inspected as usual. Good progress was made with the pruning of the older trees. The new area of the Western Road Cemetery was planted with trees and shrubs; this still requires further planting. Advice was given to the Municipal Water Engineer, concerning the treatment of grass areas and the planting of trees and shrubs in the Vale of Temple and at Batu Ferringi. A report on possible planting in the neighbourhood of the Hill railway was submitted. As in former years, advice was given by the Asst. Curator to a number of firms and private individuals concerning the layout and maintenance of grounds in their charge.

March 17th, 1933.

R. E. HOLTTUM, Director of Gardens, S.S. 



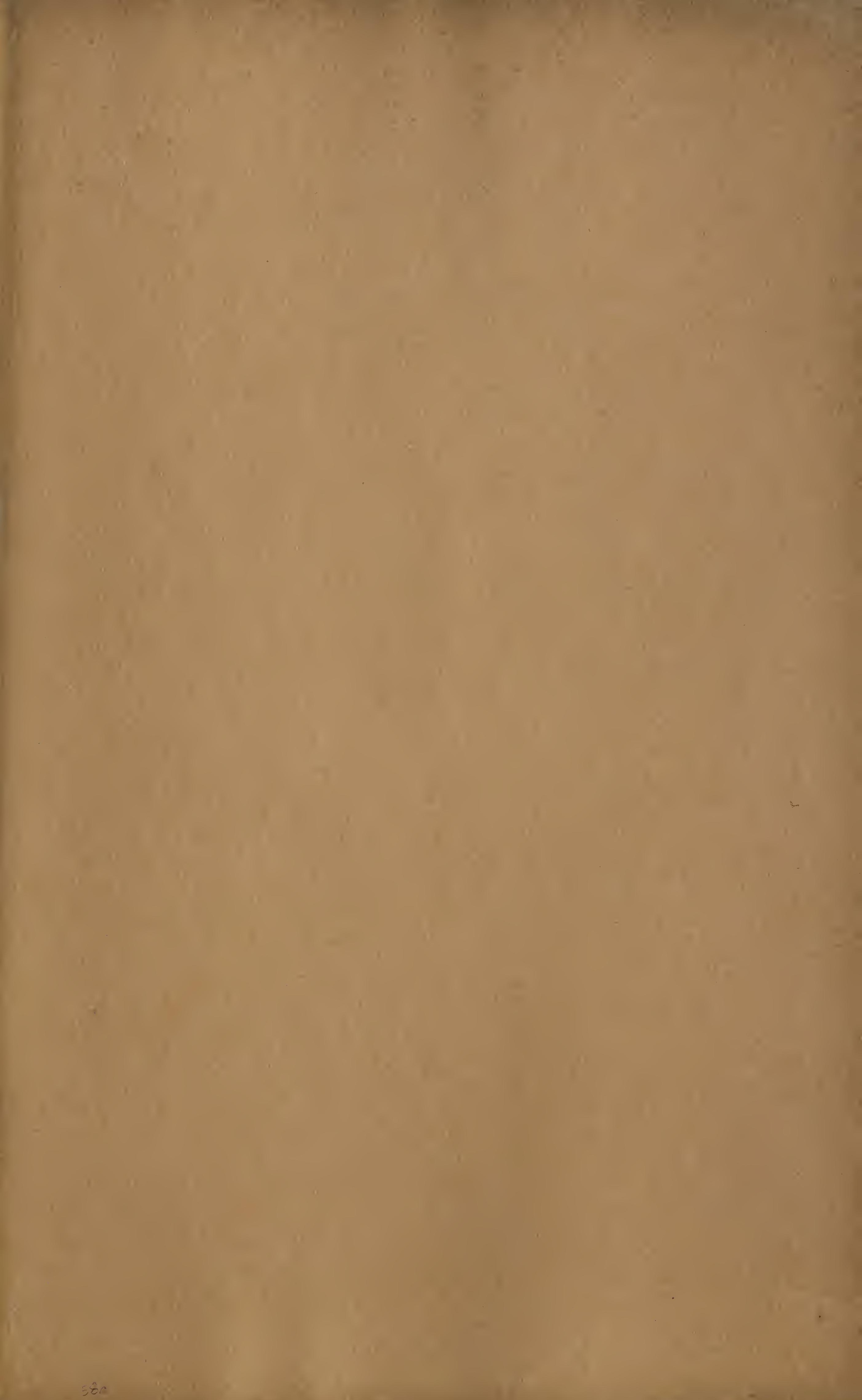





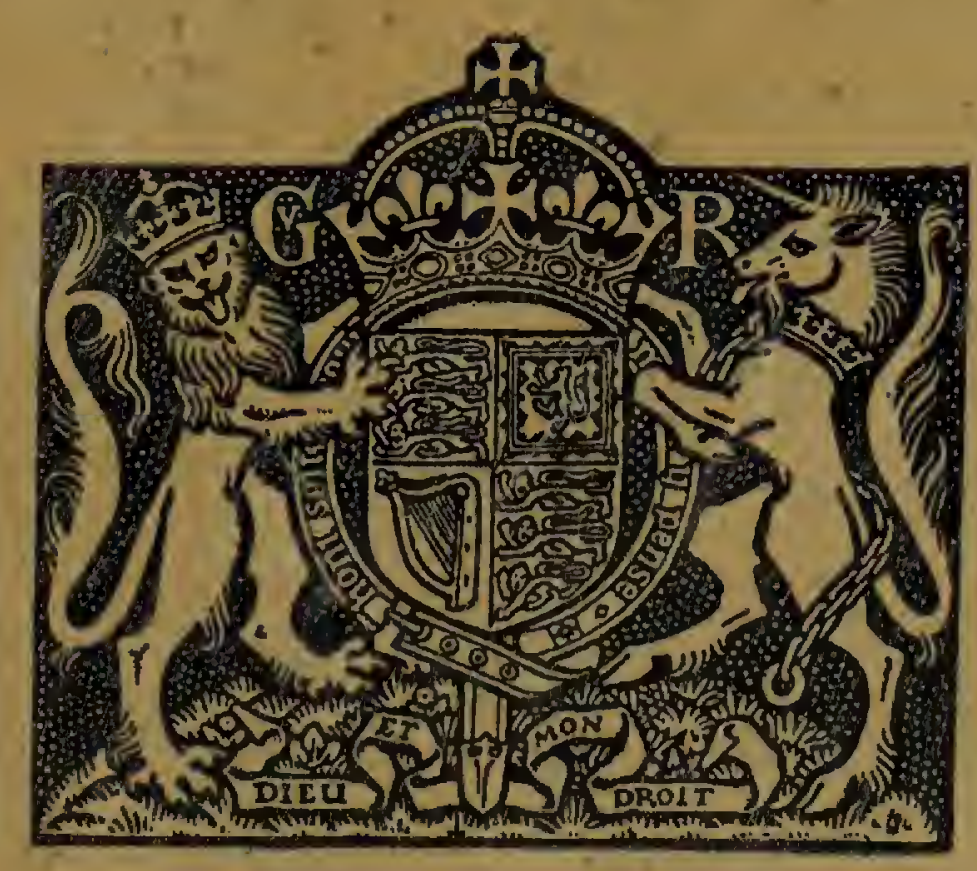

STRAITS SETTLEMENTS

\section{Annual Report of the Director of}

\section{Gardens for the Year 1933}

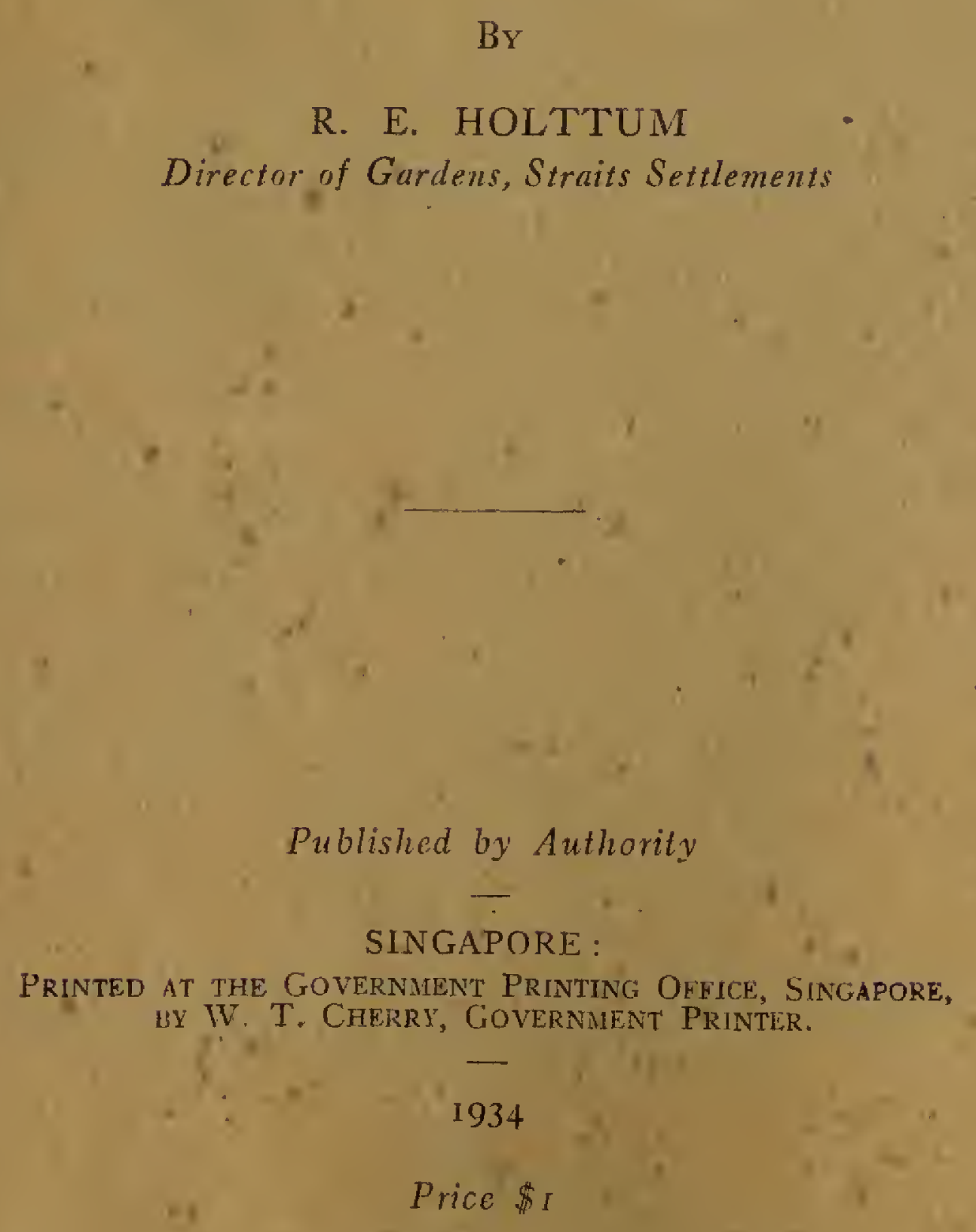





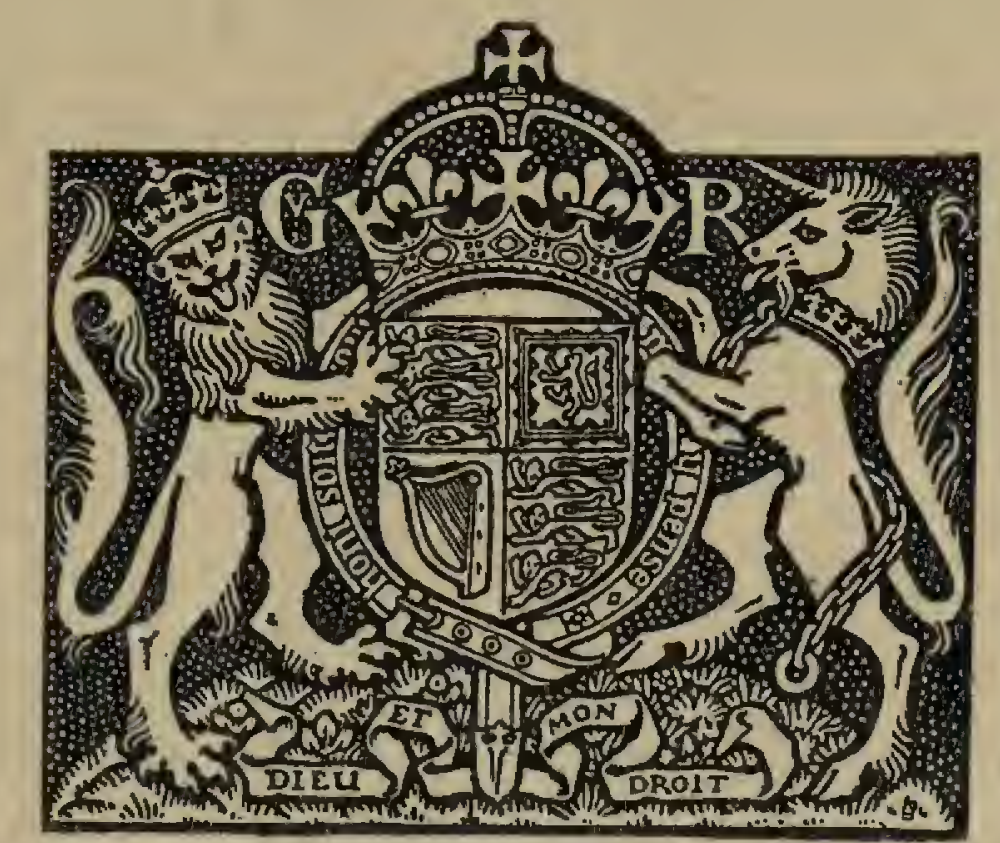

STRAITS SETTLEMENTS

\section{Annual Report of the Director of}

\section{Gardens for the Year 1933}

R. E. HOLTTUM

Director of Gardens, Straits Settlements 


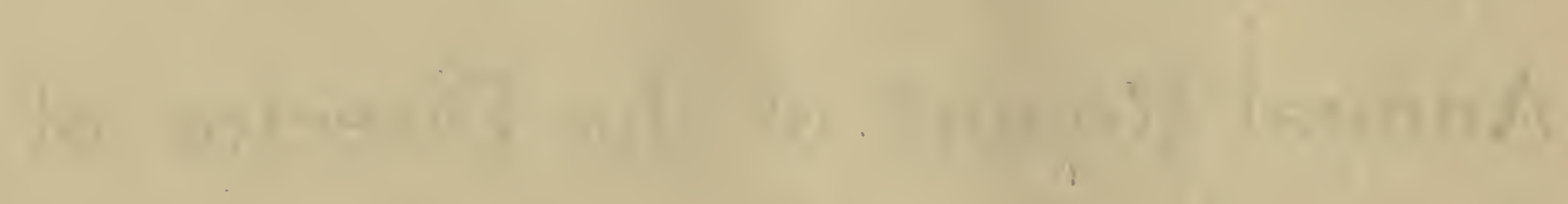

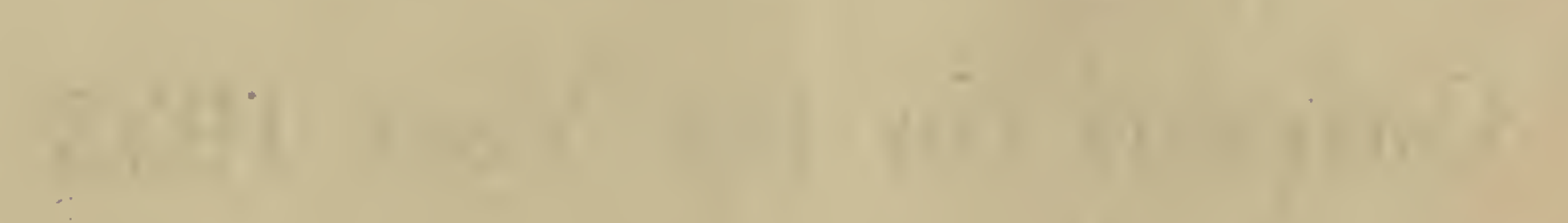




\title{
ANNUAL REPORT OF THE DIRECTOR OF GARDENS, STRAITS SETTLEMENTS FOR THE YEAR 1933
}

\author{
By R. E. HoLTTum, M.A., F.L.S. \\ STAFF
}

The Director was in charge throughout the year. Mr. M. R. HENDERSON, Curator of the Herbarium, and Mr. J. LENNON, Assistant Curator Parks were on duty throughout the year. Mr. E. J. H. CoRNER, Assistant Director was absent on furlough from June 17th and received one month's extension of leave, to work on fungus specimens at Kew. Mr. C. X. FurTado, Assistant Botanist, was granted permission to visit Berlin Botanic Garden, to study palms, in place of ordinary leave, and was absent from Singapore from 17th April, 1933. Mr. F. FLIPPANCE, Assistant Curator, Waterfall Gardens, Penang, was absent on furlough from April 12th to December 7th. Mr. G. A. BEST was transferred to Penang to take charge during Mr. FLIPPANCE'S absence and went on furlough on December 9 th. There was no change in the local staff.

\section{LABOUR}

The average number of gardeners and coolies employed at Singapore was 84 , at Penang 53. Wages remained as during the latter part of 1932. There were a number of cases of malaria among coolies at Penang between February and May; the matter was taken in hand by the Health Department. Antimalarial work in the Waterfall Garden was continued by the Health Department throughout thel year. One death occurred among the coolies employed on the hill at Penang. The health of labourers at Singapore was good.

\section{REVENUE}

The revenue from the sale of plants etc. was as follows:-

\section{Singapore-}

Sale of plants and seeds
Inspection fees etc.

Rents

Penaing-

Sale of plants and seeds ..
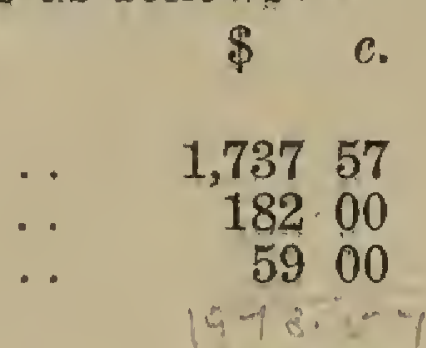

29528

In addition, the Municipal Commissioners at both Singapore and Penang paid to the Government a sum of $\$ 100$ monthly for the services of Gardens officers in connection with supervision of planting roadside trees etc.

\section{PLANT COLLECTIONS AND FIELD EXCURSIONS}

Mr. CoRNer continued his investigations of the swamp forest at the 15 th mile, Jurong Road. An attempt was made to obtain as complete as possible a photographic record of the trees of this forest, as it was being felled. The numbers of individual trees of each species in two acres of the forest were counted, and similarly, for a preliminary comparison, in $23 / 4$, acres of the swamp forest by Mandai Road. During the course of this work several little known species of botanical interest have been discovered. $\mathrm{Mr}$. CoRNER also made a few excursions to the Sungei Tiram, Johore, and grateful thanks are expressed to Messrs. LlOYd and Reginato, of Ulu Tiram Estate, for their assistance and hospitality.

The Director took leave in February and visited Sumatra, where he made small collections of specimens on Mt. Dempo, Korinchi Peak, and Mt. Merapi 
for addition to the Gardens herbarium. Permission to collect in the nature reserve of Korinchi was obtained from the Government of Netherlands India.

The Director also paid a short visit, from Penang, in September, to the vicinity of Kampong Naka, Kedah, recently opened up by a new road. The vegetation is largely of a secondary nature, but a number of interesting plants were found, including an oak not previously known in the Peninsula, a new Peristylus, a rare bamboo and some little-known grasses. In connection with this visit the assistance of Mr. W. N. SANDS, Principal Agricultural Officer, Kedah, is gratefully acknowledged.

The principal field expedition during the year was made, with the permission of Government, by Mr. C. E. CARR, who was employed for the purpose on a temporary basis. Mr. CARR spent several months on the slopes of Mount Kinabalu, British North Borneo, and collected nearly 2,000 numbers, with little duplication, including nearly 700 species of orchids, which he made his special study. A considerable number of the orchids are new species. The whole collection is an exceedingly valuable one.

\section{HERBARIUM WORK AND OTHER INVESTIGATIONS}

\section{MR. HENDERSON'S REPORT ON WORK IN THE GENERAL HERBARIUM}

The beginning of the year was mainly occupied in the completion of a paper or additions to the flora of the Peninsula. This was published in the Gardens' Bulletin in May, and in it 45 species were recorded as new to the flora, 29 of them being described as new to science.

From August onwards Mr. C. E. CARR's extensive collections from Mount Kinabalu, British North Borneo, were worked over and preliminary identifications made.

During the year a considerable amount of material was sent in for identification by the Rubber Research Institute and planters in connection with "rubber forestry". This material is almost wholly of plants growing as natural cover under rubber, and as a rule the specimens are scrappy and sometimes not well preserved, so that it is not always possible to identify them further than the genus. From a botanical point of view this material is usually uninteresting, but occasionally specimens are sent which show interesting extensions of the known range of the plant. Salvia prinoides, a South American Labiate, was sent from Bukit Paloh, Johore, where it is described as being fairly common amongst the natural ground cover. It has no doubt been introduced, but it has not previously been recorded from the Peninsula. Hyptis capitata, a Mexican Labiate, was sent from Selborne Plantation, Pahang. It has been recorded only once before from the Peninsula as an introduction. Eupatorium odoratum, a shrubby Composite of American origin which is considered to be a serious pest in Siamese forests, has been found to be spreading rather rapidly southwards and is now known from the North Johore border.

Some estates are now building up small reference herbaria of named plants, and in one instance a number of sets of named and mounted specimens, amounting to about 800 sheets, was supplied at a charge which covered cost of collection, preparation and materials.

An investigation into the varieties of Derris cultivated for "tuba" was undertaken with a view to providing a simple method of distinguishing them in the field, and a short illustrated paper was ready for publication at the end of the year.

Approximately 4,000 sheets were mounted during the year. Of these approximately 2,000 were of specimens acquired by exchange.

During the early part of the year, Mr. C. X. FurTado, Assistant Botanist, was employed in preparation for the studies of palms he later carried out at Berlin.

Duplicate herbarium material has been sent as exchanges to the following:-

Royal Botanic Gardens, Kew

Imperial University, Taiwan ...

Botanic Gardens, Buitenzorg, Java $\quad \ldots .6219$

Royal Botanic Gardens, Caicutta $\quad \ldots . \quad \ldots \quad 178$

Dr. E. D. MERRILL, New York .. $\quad$. $\quad \ldots .145$

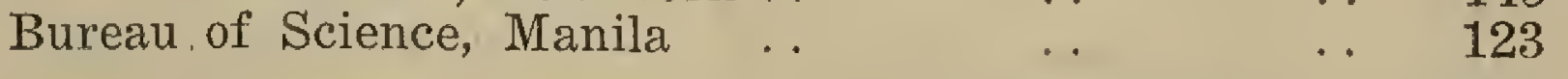

Carry forward .. $\overline{1,246}$ 


\begin{tabular}{|c|c|c|}
\hline Imperial Forestry Institute, Oxford & & 117 \\
\hline The Government Botanist, Brisbane & & 103 \\
\hline Forest Research Institute, Kuala Lumpur . & & 102 \\
\hline British Museum of Natural History & & 37 \\
\hline Department of Agriculture, Pretoria, South Africa & & 87 \\
\hline Arnold Arboretum, U. S. A. & . & 73 \\
\hline University of Cambridge & . & 72 \\
\hline Sun Yatsen University, Canton & & \\
\hline Botanical Section, Ministry of Commerce, Bangkok & & \\
\hline Forest Research Institute, Dehra Dun, India & . & \\
\hline Professor H. P. Brown, New York & & 40 \\
\hline Professor L. H. BaILEY, New York & . & \\
\hline Total & & \\
\hline
\end{tabular}

Duplicate timber specimens were distributed as follows:-

Professor H. P. Brown, New York .. $\quad . .40$

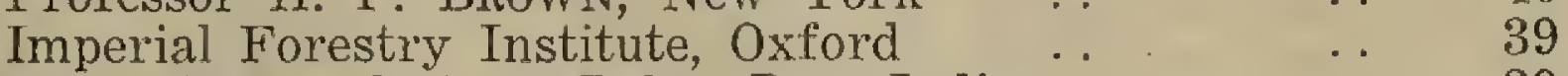

Forest Research Inst., Dehra Dun, India . . $\quad$. 39

Royal Botanic Gardens, Kew .. $\quad$.. $\quad \ldots .38$

Arnold Arboretum, U. S. A. . . $\quad$. . $\quad$.. 34

Forest Research Institute, Kuala Lumpur . . . . . 33

Botanic Gardens, Buitenzorg, Java $\quad \ldots . \quad \ldots .30$

Botanical Section, Ministry of Commerce, Bangkok . . 3

Total .. 256

Herbarium material was lent to specialists as follows:-

Dr. L. DiELs, Berlin (Anonaceae, Menispermaceae, Meliaceae, Connaraceae) .. $\quad$. 1,301

Bureau of Science, Manila (Derris) … 297

Forest Research Institute, Kuala/Lumpur (Dipterocar-

$\begin{array}{cccc}\text { paceae) } & \ldots & & 88 \\ \text { Botanic Gardens, Buitenzorg, Java } & \ldots & \ldots & 10\end{array}$

Total $\quad \ldots \quad \overline{1,696}$

Duplicates have been recelved in exchange from the following:-

Agricultural College, Coimbatore, India.

Botanical Section, Department of Agriculture, Pretoria, South Africa.

Taihoku Imperial University, Taiwan.

Arnold Arboretum, U. S. A.

Metropolitan Museum of Natural History, Nanking, China.

Smithsonian Institution, U. S. A.

Bureau of Science, Manila.

Botanic Gardens, Buitenzorg, Java.

Algemeen Proefstation voor den Landbouw, Java.

Thanks are due to the following for the loan of valuable material for comparison:-

Royal Botanic Gardens, Calcutta; the Botanic Gardens, Buitenzorg, Java; The Curator, Sarawak Museum; Mr. J. N. MiLsum.

Help from the Director, Royal Botanic Gardens, Kew, and from Mr. I. H. BURKILL in the naming of critical plants is gratefully acknowledged.

\section{BAMBOOS}

With the assistance of Mr. J. L. PestanA, Laboratory Assistant, the Director undertook a preliminary study of the bamboos in cultivation in the Gardens, and those in the immediate neighbourhood. Specimens of perfect culm-sheaths from all plants were collected and studied, and it was found possible to distinguish all species by this means. In many cases the culm sheaths had not previously been described, and valuable information was collected which should lead to better identification of bamboos in the future. Flowers of some species are still required in order to make possible their identification. It is hoped to continue this work, as opportunity offers, with the aim of acquiring a knowledge which will enable all local bamboos to be identified vegetatively. 


\section{CRYPTOGaMic HeRBaRIUM}

Mr. CORNER continued his work on the Polyporaceae, and has now examined in detail about 150 species. He took material of these to Kew for comparison with type material. Mr. CORNER also continued his observations on the growth rate of Polypores, and general systematic work on other Basidiomycetes so far as time allowed.

Several interesting species of Fomes were received for identification from the Forestry Department, Straits Settlements and Federated Malay States, Mr. WILKINSON, Assistant Conservator of Forests, Kedah, sent some excellent specimens of Polyporus rhinocerotis.

The loan from the Department of Agriculture, Peradeniya, Ceylon, of type material and illustrations of Hygrophorus is gratefully acknowledged.

About 200 duplicate specimens from the fungus herbarium of $\mathrm{O}$. A. REINKING were received from the United States Department of Agriculture.

The Director continued his work on ferns, being chiefly occupied with Kinabalu collections, and with Peninsula tree ferns. A paper on Kinabalu ferns, written in collaboration with Dr. CARL CHRISTENSEN of Copenhagen, was ready for printing at the close of the year. The Director also studied the cultivated species and varieties of Maidenhair ferns (Adiantum) and prepared two papers on them for publication in the M. A. H. A. magazine.

\section{PUBLICATIONS}

Vol. VII part 2 of the Gardens Bulletin was published on May 10th. This contained three papers:-

1. Additions to the Flora of the Malay Peninsula, by M. R. HENDERSON. This contains descriptions and illustrations of 29 new species, and records of a further 16 species reported for the first time as occurring in the Peninsula. The publication of this paper was made possible by study at Kew during Mr. HeNDERSON's leave in 1932.

2. Notes on Malayan Dipterocarpaceae by C. F. Symington.

3. Ennumeration of Malayan Ebenaceae, by R. C. BAKHUIZEN VAN DEN BRINK. This paper contains descriptions of 24 new species from the Malay Peninsula.

Mr. CoRNER's paper "A revision of the Malayan species of Ficus: Covellia and Neomorphe" was published in the Journal of the Malayan Branch Royal Asiatic Society Vol. VI, part 1.

Mr. CORNER also sent a paper on Collybia apalosarca for publication in the Transactions of the British Mycological Society.

Mr. C. E. CARR, working partly in the Gardens Herbarium, published a paper on a collection of orchids from Sumatra in the Journal of the Malayan Branch, Royal Asiatic Society.

The Director acted as horticultural editor to the Malayan Agri-Horticultural Association's Magazine, four issues of which appeared during the year, and prepared a number of articles for publication in the Magazine. Other members of the Gardens staff also contributed.

The Director also contributed to the Malayan Orchid Review, No. 3, articles on the cultivation of hybrid orchids and notes on some interesting species.

A revised Seed Exchange List was issued during the year.

PLANTS OU'TWARDS-

\section{PLANTS OUTWARDS AND INWARDS}

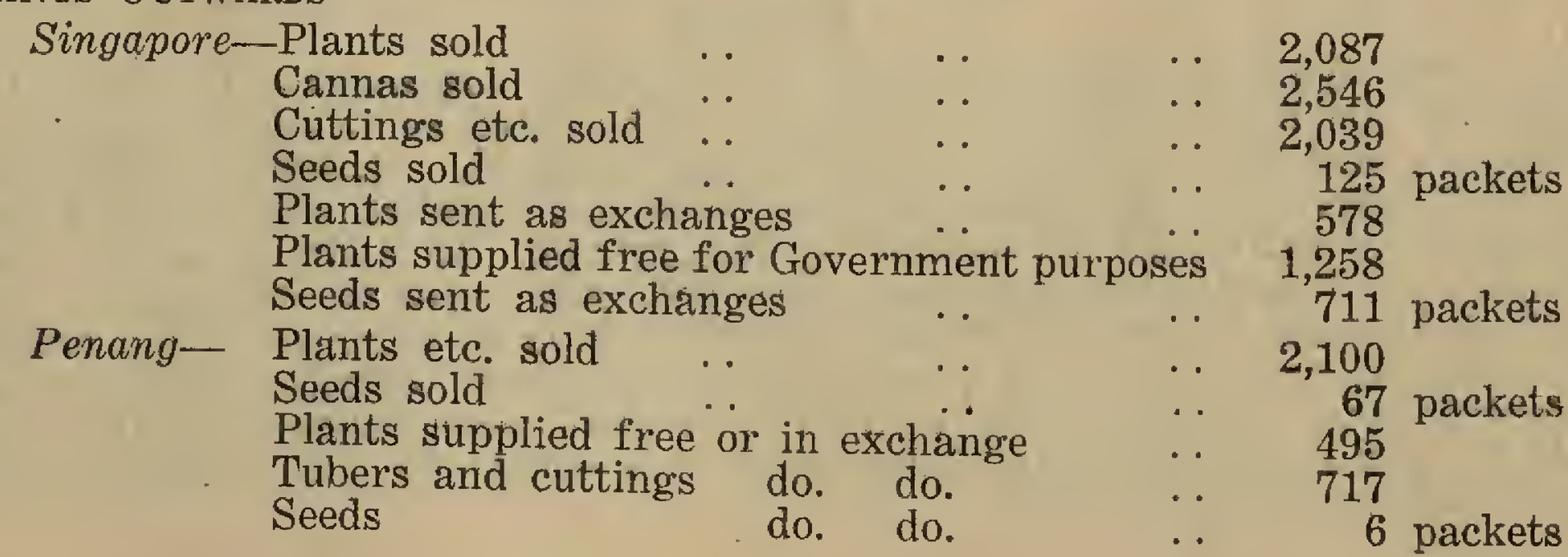


PLANTS INWARDS-

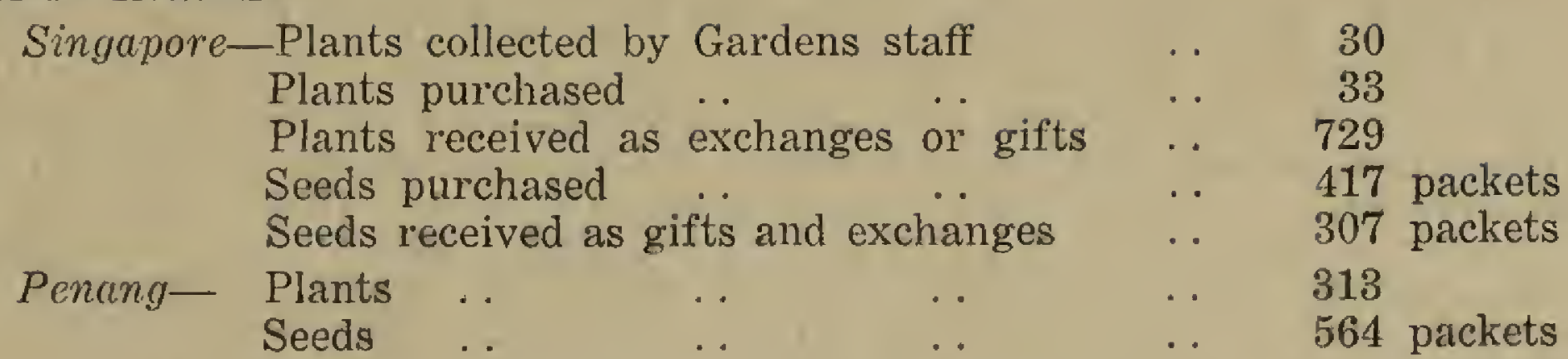

Gifts are gratefully acknowledged from the following:-

Mr's. Brandon Bravo, Mr. E. D. Butler, H. R. H. Prince Chatra Mongol (Bangkok), Dr. N. G. Cooper, Dr. L. Croizat, Mr. J. A. LE Doux, Mr. E. Galistan, Rev. Keppel Garnier, Mr. R. Hill, Col. J. N. Horlick, Mr. H. Huebner, Mr. H. L. Jeppesen, Capt. H. A. Johnstone, Dr. J. R. Kay-Mowat, Mr. W. P. Millar, Dr. H. Moxham, Mr. P. C. B. Newington, Mr. R. Page, Dr. W. T. Quaife, Mr. B. K. Sahee, A. K. Shaik Mohamed, Mr. C. Takahashi, Mr. Z. Teruya, Mr. W. F. Tweedie, Rev. Nigel WILLIAMS.

Special thanks are also due to Sir JeremiaH COLMAN BART., who made a very generous exchange for orchid plants sent from Singapore.

Seeds were despatched from Singapore to 42 other botanical institutions.

\section{THE BOTANIC GARDENS, SINGAPORE}

The Plant House. - Numerous small additions were made to the plant house, but the general arrangement was unchanged. The descriptive labels of groups and plants of interest were maintained. Several local ferns were added to the collections, and also some new varieties of maidenhair ferns, of which about 25 species and varieties are now in cultivation. Of the local ferns, a plant of Dipteris conjugata was brought from Penang and continued to grow well after arrival. It is probable that this is the first time a plant of this difficult species has been exhibited as a pot plant in Singapore. This species and other local ferns have responded strongly to manuring.

Notes on Plants of Interest.-A small species of the family Compositre, introduced under a wrong name from Calcutta, proves to belong to the genus Hymenatherum, probably $H$. tenuilobum; it is a useful small bedding plant, remaining in flower for a considerable period. Zephyranthes aurea, obtained by exchange from the Istana Gardens, Johore, is a very fine species but apparently not very free flowering under local conditions. Anchusa myosotidiflor flowered very freely and produced seeds. It grows strongly in Singapore and is a very useful addition to our list of annuals, its blue flowers being very attractive. Sanvitalia procumbens also flowered freely and is an annual which deserves further trial. It may be propagated by cuttings. Anoda lavateroides grew fairly well and flowered, but the flowers were poor and of no decorative value. A beautiful variegated variety of Tapioca (Manihot utillissima), originating from Java, was presented by the Foreman Gardener, SAPPI BIN HASSAN, and grew well. It is a very useful addition to our decorative shrubs. Clerodendron ugandense not having grown very strongly on its own roots, the experiment of grafting it on the local $C$. serratum was tried, and a remarkable response was obtained. The scion attained a height of 8 feet in about 6 months. A variety of Thevetia nerifolia with orange flowers, introduced from Formosa, began to flower during the year. Its flowering was not so free as that of the typical yellow kind. Voacanga grandifolia, introduced a few years ago from Bombay, flowered for the first time during the year. The plants of Cupressus macrocarpa and $C$. Knightiana raised from Peradeniya seeds made remarkably good growth during the year, and are almost as large as those planted on the hill at Penang. The trees of Brownea grandiceps by the Office Ring Road having produced long branches overhanging the road and needing support, an arch of steel work was constructed by the Trade School for the purpose. By the end of the year branches of the two trees almost completely covered the arch. The collection of Cannas was added to by exchange with Kuala Lumpur.

The Lake.-The lake was cleaned thoroughly of weeds in August, and the Nymphaeas replanted, with resulting considerable improvement in flowering. Two more plants of Victorial regia were added. The bank of the lake below the Main Gate Road was partly re-made and re-turfed, as owing to much wash 
of storm water from the road it had become very uneven and was difficult to keep tidy. The grass border on the far side of the lake was also re-made and turfed.

New Planting.-Pepper and Betel-pepper plants were added to the group spices near the office; Cinnamon, cloves, nutmeg, pepper and Vanilla are now represented. It is intended to add ginger, turmeric and other plants. Three tree ferns (Cibotium spp.) from Honolulu, kindly sent by Dr. H. L. LYoN, were planted, two near the lake and one in the plant house. All started new growth immediately, but it is too soon to say whether they will become really established.

The following recently, introduced woody plants were planted:-

TREES.-Irvingia malayana, Garcinia hombroniana, Cecropia sp. (origin Honolulu), Guazuma ulmifolia (Mexico), Mangifera caesia, Ceiba pentandra var. Caribaea (origin Buitenzorg), Araucaria excelsa, Erythrina corallodendron (Mexico), E. indica (Calcutta), E. stricta (Calcutta), E. sp. (Santa Lucia), Ficus indica, $F$. calophylla, $F$. viridicarpa, $F$. hirta, $F$. glomerata, $F$. Miquelii, $F$. cotinifolia (Mexico), $F$. involuta (Mexico), Cassia renigera.

PALMS.-Sabal Blackburnianum (from Bermuda), S. mexicanum (Br. Guiana), Trachycarpus excelsus (from Coimbra), Zalacca edulis, Hyophorbe amaricaulis, Licuala sp. (Siam), Phoenix madagascariensis (Tamatave), Coccothrinax barbadensis (from Hawaii), Actinophloeus sp. (Sibolangit), Bactis ottostaffiana (from Brazil).

SHRUBS.--Vitex agnus castus (from Washington), Carica heptaphylla (Mexico), Bauhinia malabarica, B. tomentosa (from Dehra Dun), B. sp. (Colombia), Plumeria acutifolia (Mexico), Ruellia longifolia (Kew), Hamelia rovirosae (British Honduras). An additional Amherstia was planted near the Tyersall Gate.

Losses.-Another old African Oil Palm (Elaeis guineensis) from the Bandstand Hill, probably dating from about 1890, had to be removed as it was in very poor condition. The height of its trunk below the leaves was measured as 40 feet 6 ins. (12 metres). Two old Dacrydium trees have been lost during the year. Several remaining trees are showing signs of dying back, and new plants are being obtained to replace them.

General Cultivation.-About half the grass area was top-dressed with sludge from the sewage disposal works, with immediate improvement. A considerable amount of labour was expended during the wet season towards the close of the year in digging around some of the younger trees and palms, and manuring with leaf-mould and cow-dung. This has resulted in much new growth. Evidently the roots of many plants cannot penetrate into the heavy clay which constitutes the top layer of earth throughout most of the Garden. They can only obtain sufficient moisture and aeration quite near the surface, and there compete with the grass. This work of cultivation is very laborious, but it appears to be essential if we are to have good growth of young trees. One plant which has shown very great additional growth after cultivation is the Baobab (Adansonia digitata), which had made little growth during the previous two years.

Orchids.-The orchid collection generally improved considerably during the year owing to better methods of cultivation and manuring. A number of additions were made by exchange and purchase, the most notable being some hybrid Dendrobiums generously sent by Sir JEREMIAH CoLMAN, Broughtonia. plants from Mr. W. CRADWICK, Jamaica, and Dendrobium superbiens from the Bangkrabu nursery. A plant of Catasetum macrocarpum presented in 1932 by Mr. H. L. JEPPESEN made good growth and flowered.

The hybrid orchid seedlings raised in the Gardens have in many cases made good growth, and the first hybrid Vanda flowered during the year. A considerable proportion of these seedlings were raised from seeds supplied by Mr. J. LAYCOCK. Hybrid plants of Arachnis alba $\times$ Vanda Hookeriana, Arachnis alba $\times$ Renanthera Storiei, and Arachnis alba $\times$ moschifera, have made very strong growth and should flower before long. Two Spathoglottis hybrids, of $S$. aurea crossed with varieties of $S$. plica. $a$, have grown well and flowered freely, and a hybrid of the white variety of $S$. plicata with $S$. aurea has made good growth. A plant of the Philippine hybrid S. plicata var. Parsonsin has grown well, and also $S$. pubescens from Hong Kong, and it is hoped to utilise these also in future breeding work with this genus, which has great possibilities in Malaya. 


\section{THE WATERFALL GARDENS, PENANG}

The Formal Garden.-The lay-out of the Formal Garden was completed early in the year. Crazy paving was constructed for the paths, and a total length of 386 feet, 3 feet wide, was laid. Beds were made and planted with low shrubs and perennials, water lilies planted in the tank, and a semicircular seat made under the tembusu trees. Later in the year an ornamental iron entrance gate was constructed by the Penang Trade School. The Garden will shortly be completed and opened to the public.

New planting.-The collection of Bougainvilleas on lawn $\mathrm{E}$ was added to by the planting of Mrs. Fraser, formosa, and Cyperi, the two former kindly presented by the Rev. KEPPEL GARNIER. Bougainvillea formosa grew well and flowered very beautifully, and should be a most useful plant for local gardens. Its light mauve colour is very distinctive. A plant of Amherstia nobilis was placed at the upper end of section A near the Saracas. It is hoped that this will prove a more favourable situation than lawn C, where a plant formerly died. In section M, beside the Upper North Road, was planted a selection of varieties of Coffee, received from the Serdang Experimental Plantation. In section $R$ was planted the curious Scyphostegia borneensis, only known from the foot-hills of Mount Kinabalu.

Other plants of interest.-Two plants of Lagerstroemia flos-reginae, planted on lawn $\mathrm{E}$ in 1931, flowered for the first time in March 1933. The young tree of Lagerstroemia tomentosa var. Loudoni on lawn $\mathrm{S}$ flowered for a second time and appears to be well established. It is a useful addition to the ornamental trees of the Garden. Five seedlings were raised from seeds of Bougainvillea lateritia. This is the only Bougainvillea which produces seeds either at Penang or Singapore. Monochorea elata has been planted in the tank in the formal garden. Seeds received from Singapore germinated in 3 days and the plants grew to their full size and flowered in six months. Pitcaimea latifolia var. furfuracea flowered very freely and finely in the orchid and succulent garden. Its brilliant colour and tall distinctive habit make this a very striking plant.

Building and Masonry.-Works carried on by the Public Works Department in the Gardens were as follows:- the tool shed was re-roofed with galvanised iron; repairs to the Middle Bridge, necessitated by flood water having found its way behind the protective wall, were completed; the retaining wall beside plant house No. 2 was extended. The Gardens staff constructed rubble roadside drains beside the boundary hedge of the new formal garden, beside the Upper Circular Road at the approach to the Upper Bridge, and in front of plant house No. 2.

\section{GOVERNMENT HOUSE DOMAIN AND OTHER OUTSIDE CHARGES} SINGAPORE- -

Government House Domain was maintained as usual. A number of old trees, either dangerous or unsightly, had to be removed, including a very large Albizzia overhanging Cavanagh Road. Young trees of the following kinds were planted where required, chiefly near the boundaries of the Domain: Ceiba pentandra var. caribrea, Pangium edule, Mesua ferrea, Cyrtophyllum peregrinum, Adinobotrys atropurpureus, Parkia Roxburghii, Erythrina sp., Adenanthera pavonina.

The wreath on the cenotaph, and the beds in front of Raffles Statue, were maintained as in former years.

Mr. CoRner continued to supervise work of tree planting on the water catchment area. About 30 flowering trees formerly planted round the McRitchie Reservoir failed and were replaced by Spathodea. A small patch of Bĕlukar* near Bukit Brown was planted with a number of species of Ficus, some of which made good growth during the year. They were: Ficus elastica, retusa, infectoria, callophylla, glabella, indica, procera, variegata, chamaecarpa and geocarpa, about 50 plants altogether. At the Pierce Reservoir a hill near the cooly lines at the $81 / 2$ mile Thomson Road has been planted with 600 trees; the planting of another hill with similar fast growing trees has been begun. In a valley near by about 80 young plants of interesting trees requiring better soil conditions were planted; these are of the species Durio singaporensis, Myristica Maingayi, and Knema furfuracea (Myristicaceae).

Mr. LENNON continv to supervise roadside tree planting and maintenance for the Municipal Com issioners. 488 young trees were planted during the year and 210 old trees removed.

Bĕlukar = scrub. 
Advice was given concerning planting and pruning of trees and shrubs, and other matters, at the General Hospital, The Naval Base, Tanglin Barracks, Swiss Cottage Estate, Singapore Cricket Club, Singapore Swimming Club, The Hong Kong Bank, Dalvey Estate, and Watten Estate. Mr. LENNON gave a lecture and demonstration on gardening for the Y. W. C. A.

\section{PENANG-}

Hill Gardens.-The Gardens at Bel Retiro, Strawberry Hill, the Crag Hotel, Bellevue, Convalescent, Fernhill, Woodside and Hillside were maintained as in former years. At Bel Retiro considerable new planting of shrubs and trees for ornamental and screening purposes was carried out. At Strawberry Hill the big Ficus tree on the west side fell and had to be removed. At the Crag Hotel the general scheme for lay-out was further developed. The terraces below bungalow No. 4 were planted with various yellow and white-flowering plants. The terraces at the entrance, completed in 1932, were grassed. The soil on all these terraces is poor and subject to much wash in heavy rains, and plants are slow in becoming established.

Municipal Inspections.-These were carried on as in former years, and regular reports made.

Other outside duties.-Advice about planting, and planting material, were provided for the following Government grounds: The Penang Trade School, St. George's Church compound, and the Glugor section of the Coast Road.

\section{R. E. HOLTTUM,}

Director of Gardens,

Straits Settlements. 






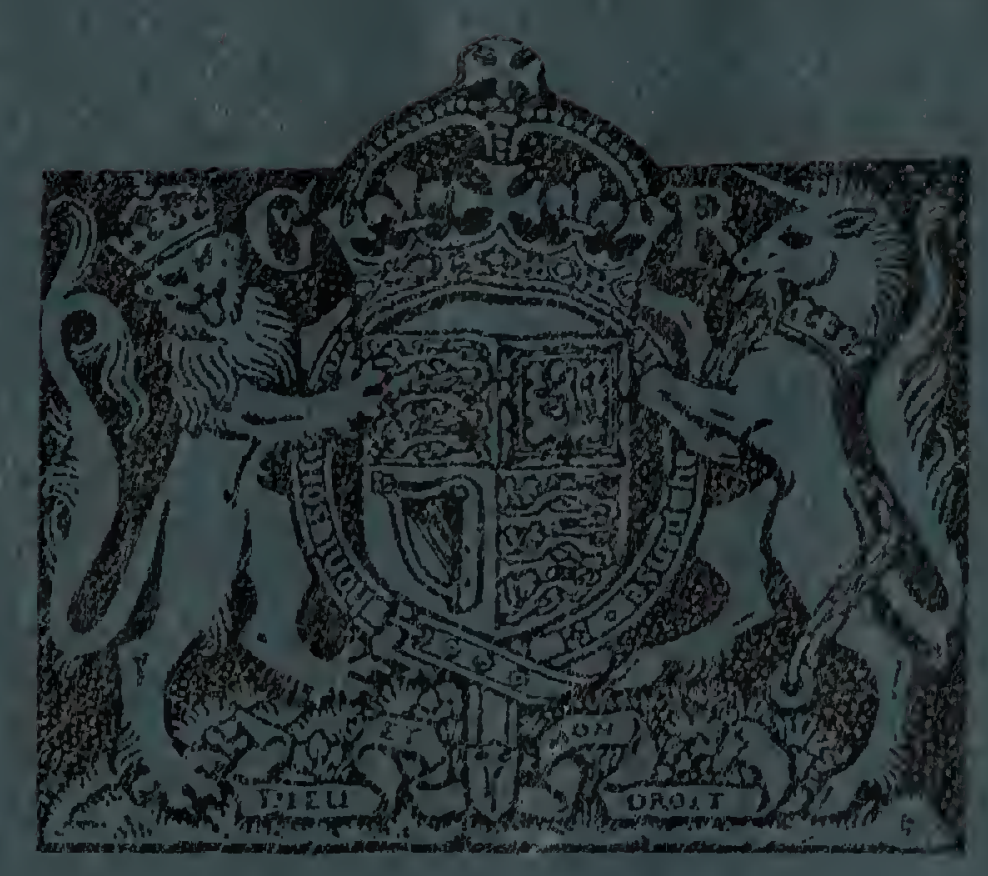

\section{STRAITS SETTLEMENTS}

\section{Annual Report of the Director of Gardens for the year 1934}

R. E. HOI TIUM, M.A.. F.L.s., Direcion of Gardens, Strats Sethments 


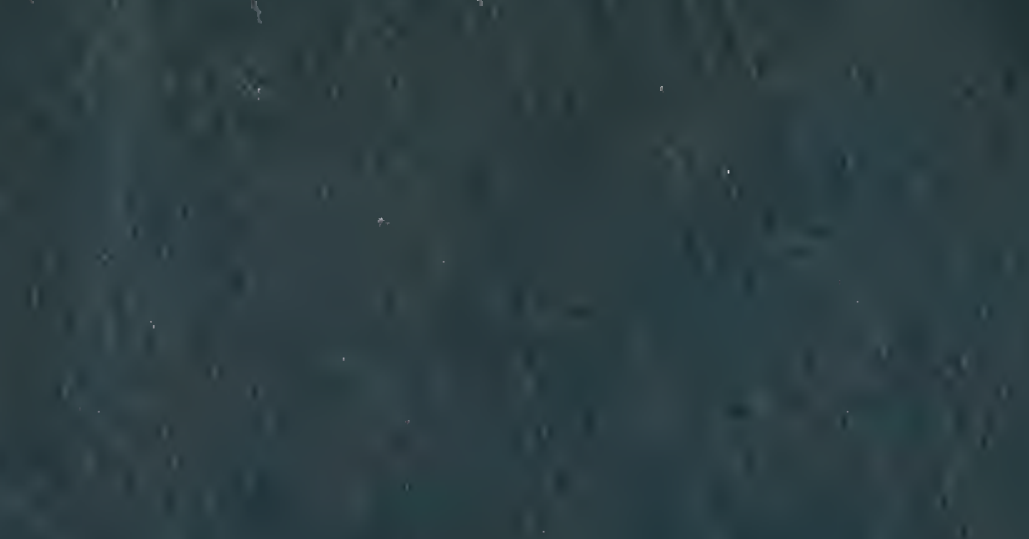

(1) $k$

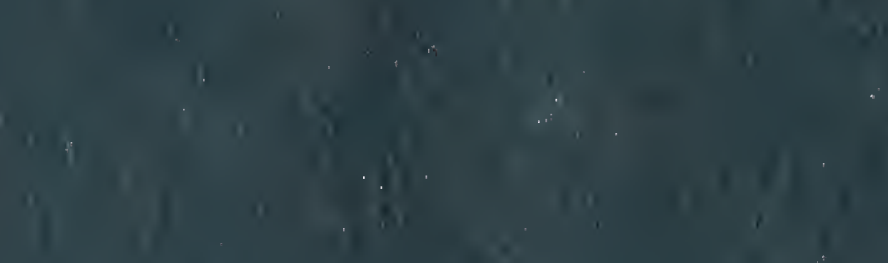

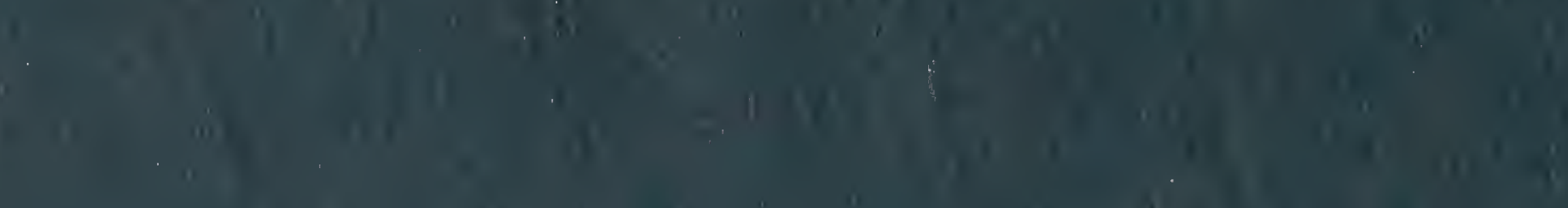

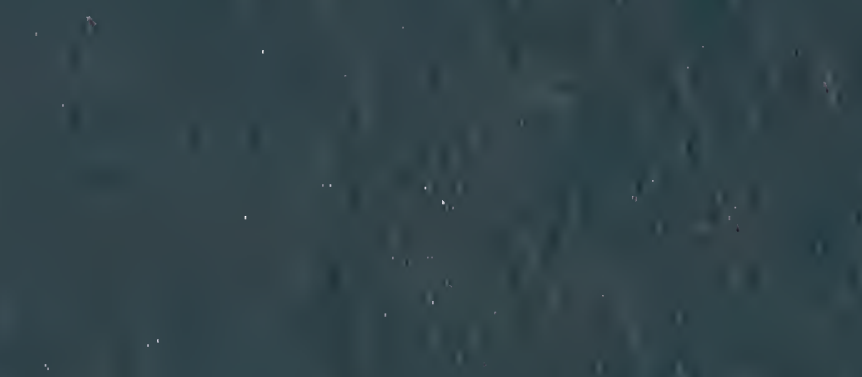

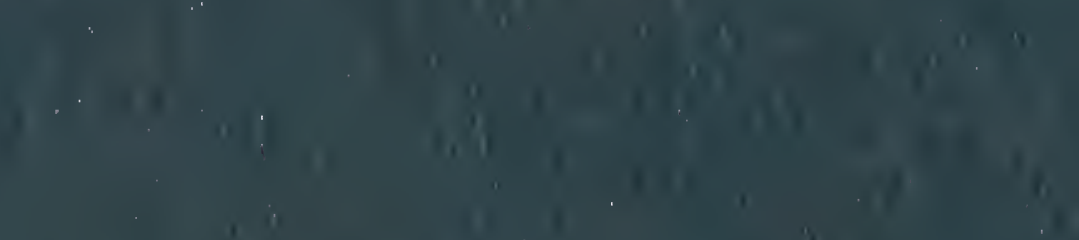

3. 1 a

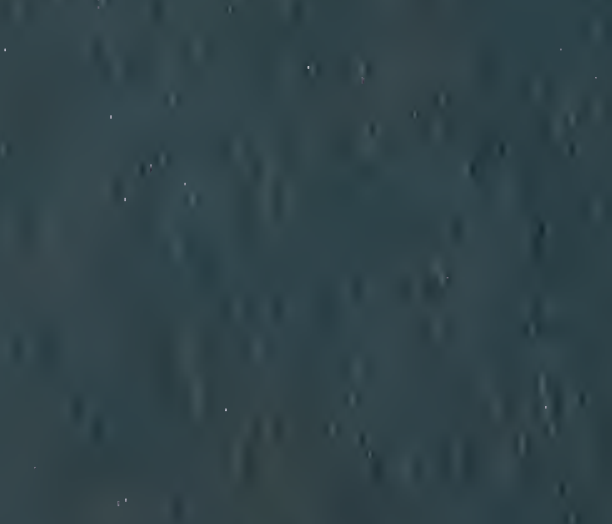

1

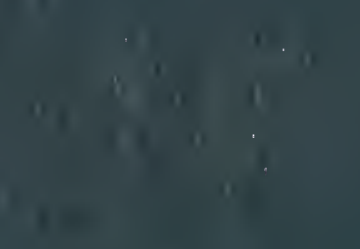

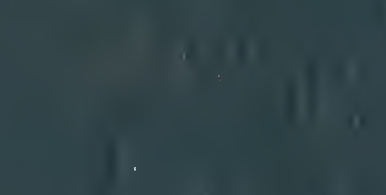
$1+2$ 


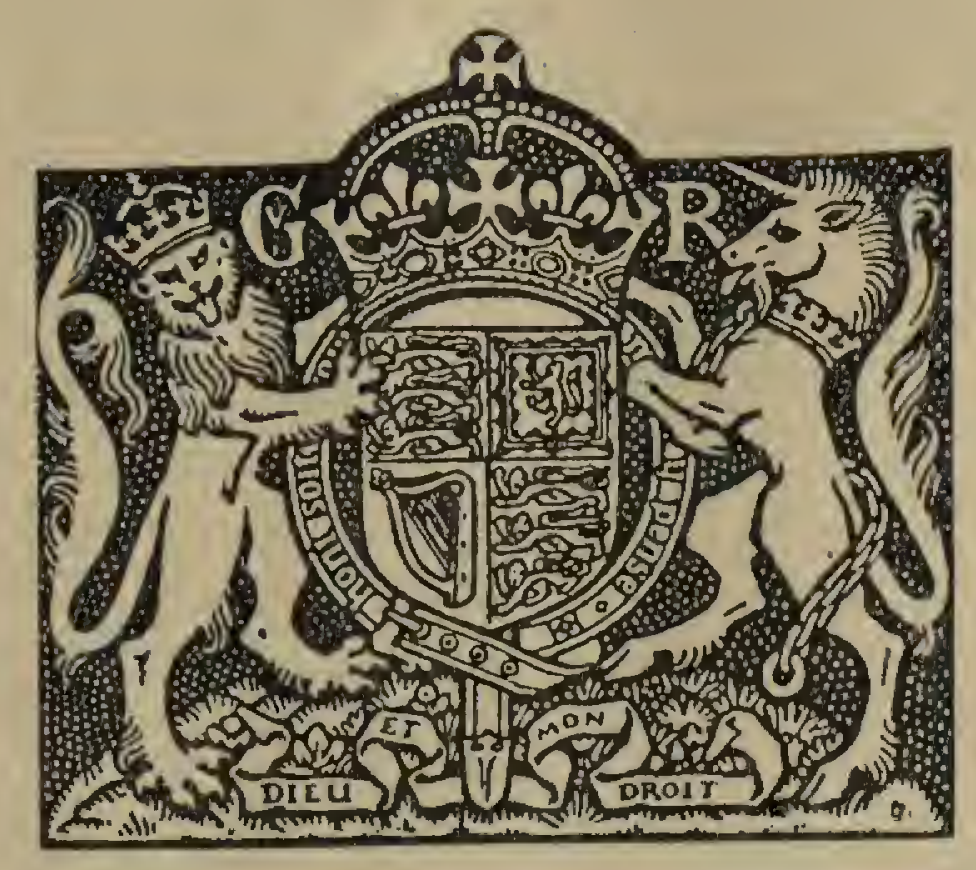

STRAITS SETTLEMENTS

\section{Annual Report of the Director of Gardens for the year 1934}





\section{(1) \\ ANNUAL REPORT OF THE DIRECTOR OF GARDENS, STRAITS SETTLEMENTS FOR THE YEAR 1934}

\section{By R. E. HoltTum, M.A., F.L.S.-Director of Gardens, Straits Settlements. STAFF}

The Director was absent on leave from March 16th to November 9th; during his absence Mr. M. R. HENDERSon acted as Director. During his leave, the Director visited the Botanic Gardens at Kew, Wisley, Cambridge, Leiden, Utrecht, Groningen, Glasgow and Edinburgh; he also examined specimens at the herbaria at Kew, The British Museum, Leiden and Copenhagen. Mr. E. J. H. CoRNER, Assistant Director, returned from leave on March 1st; during his leave Mr. CORNER spent about three months studying fungus specimens in the herbarium at Kew, and working at the Botany School, Cambridge. Mr. Fluppance, Assistant Curator, Penang, was on duty throughout the year. Mr. G. A. BEST, Assistant Curator, Singapore, was absent on leave until August 31st. Mr. J. LENNoN, Assistant Curator, Parks, Singapore, was unfortunately obliged to retire on account of ill-health after 13 years service; he ceased duty on 12 th September to take leave prior to retirement. Mr. C. X. FURTADo, Assistant Botanist, returned to Singapore on May 1st after a year's absence, the greater part of which was spent studying palms at Berlin and London. This absence on duty was taken instead of half-pay leave; a report on Mr. FURTADo's work during this period is given under the heading of Herbarium Work. DoRAISAMY, Carpenter, at Penang, retired at the end of the year after 17 years valuable service. The other members of the staff were on duty throughout the year.

\section{LABOUR}

The average number of gardeners and coolies at Singapore was 82; at Penang 55. Wages remained unchanged. At Penang, only one case of Malaria was reported during the year; this is a great improvement, and is due to the programme of anti-malarial work carried out by the Senior Health Officer. At Singapore there were seven hospital cases (various diseases) among the daily paid workers during the year.

\section{REVENUE}

The revenue from the sale of plants, etc. was as follows:-

$$
\begin{aligned}
& \text { Singapore- } \\
& \text { Sale of plants and seeds } \quad \ldots \quad r \quad \ldots \quad 1,67154
\end{aligned}
$$

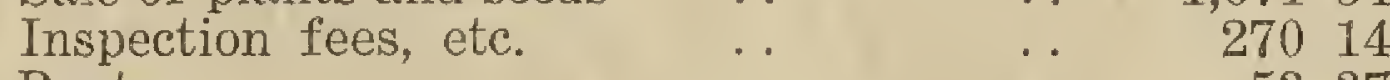

$$
\begin{aligned}
& \begin{array}{lllll}
\text { Rents } & \ldots & \ldots & \ldots & 5337
\end{array} \\
& \text { Penang- } \\
& \text {. } \quad \text {. } \quad 35490
\end{aligned}
$$

In addition to the above, the Municipal Commissioners at both Singapore and Penang contributed $\$ 100$ monthly for the services of Gardens officers in connection with the planting and maintenance of roadside trees, etc.

\section{PLANT COLLECTIONS AND FIELD EXCURSIONS}

Mr. Corner continued his study of the swampy forest of Johore. From June 9th to 24th he made an expedition to the East Coast to study the coastal flora at Jason Bay and the swampy forest on the Sedili Kechil river. The locality was particularly suitable for the investigation of the succession of 
forest on the sandbanks which develop across the river mouths. Many interesting or little-known species were discovered, including Inocarpus eduits (the so-called Otaheite Chestnut, not previously known as indigenous to the Peninsula), a species of Phaleria (a genus not hitherto found in the Peninsula), Chisocheton pentandrus (a Philippine species), and several other species which will need further study. Mx. CoRNER unfortunately contracted Japanese River fever on this expedition; he managed to return to Singapore in time for treatment, and recovered after a very serious illness. Mr. CoRNER also made several short trips to the vicinity of Mawai, Johore, and grateful thanks are expressed to $\mathrm{Mr}$. H. G. GRIEve of Tebrau Estate for his assistance and hospitality on these occasions.

In June the plant collector Kiah accompanied Mr. C. F. Symington of the Forest Department on a short trip to Gunong Tapis, near Kuantan, Pahang. No previous botanical collections are known to have been made on this mountain, and the present one, although small, is of considerable interest.

In November Mr. Henderson visited Pulau Langkawi for the express purpose of collecting on the limestone there. Collections were made on the limestone ridges on the east of the island, on Pulau Timun, and on the north and south coasts of Pulau Dayang Bunting, and a day was spent at Kisap, near Kuah, where there is a small limestone hill. Unfortunately very few trees were in flower at this time and from this point of view the expedition was disappointing. However, a very good general idea of the composition of the limestone flora here was obtained, and of plants other than trees, many of interest were found. Perhaps the most interesting was a species of Lysimachia which constitutes the first record of the family Primulaceae from our area.

\section{HERBARIUM WORI AND OTHER INVESTIGATIONS}

Mr. M. R. HENDERSon, Curator of the Herbarium, carried on the usual routine work and named collections made during the year.

Duplicates sent out in exchange:-

Royal Botanic Gardens, Kew ..

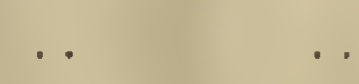

717

Botanic Gardens, Buitenzorg, Java ... . 575

Forest Research Institute, Kepong, F.M.S. ․ . 362

R. C. Ching, Fan Memorial Institute, China (Ferns) 276

Smithsonian Institution, Washington, U.S.A. (Ferns) 195

Bureau of Science, Manila, Philippines . . $\quad$. . 189

British Museum of Natural History _. $\quad$. 136

H. H. BARTLETT, University of Michigan, U.S.A. . . 134

Dr. E. B. COPELAND (Ferns) . $\quad \ldots \quad \ldots 112$

Imperial Forestry Institute, Oxford $\quad \ldots \quad$. . 98

The Govt. Botanist, Brisbane, Australia . . $\quad$. 997

Sunyat Sen University, Canton, China $\quad \ldots \quad$. . $\quad 92$

Royal Botanic Gardens, Calcutta $\quad \ldots \quad \ldots 78$

Dr. E. D. Merrill, New York Botanical Garden . 77

Academica Sinica, Nanking, China _. $\quad$. $\quad 66$

Botany School, University of Cambridge .. $\quad$.. 57

Arnold Arboretum, U.S.A. . . $\quad \ldots \quad$. $\quad 27$

Material sent out on loan:-

Royal Botanic Gardens, Kew (Bornean Melastomaceae and miscellaneous sheets for determination) ..

Forest Research Institute, Kepong (Dipterocarpaceae, Cedrela)

.. .. .. ..

Dr. J. J. SмiтH, Holland (Ericaceae) . . . 244

Dr. DANsER, Holland (Arceuthobium Dacrydii) _. 3 
Duplicate timber specimens distributed as follows:Arnold Arboretum, U.S.A. . . . . . $\quad$. 18 Royal Botanic Gardens, Kew $\ldots \quad \ldots \quad \ldots \quad \ldots 17$ Imperial Forestry Institute, Oxford _ . $\quad \ldots .17$ Forest Research Institute, Kepong $\quad$. $\quad$. 10

Duplicates received in Exchange from:Academica Sinica, Nanking, China

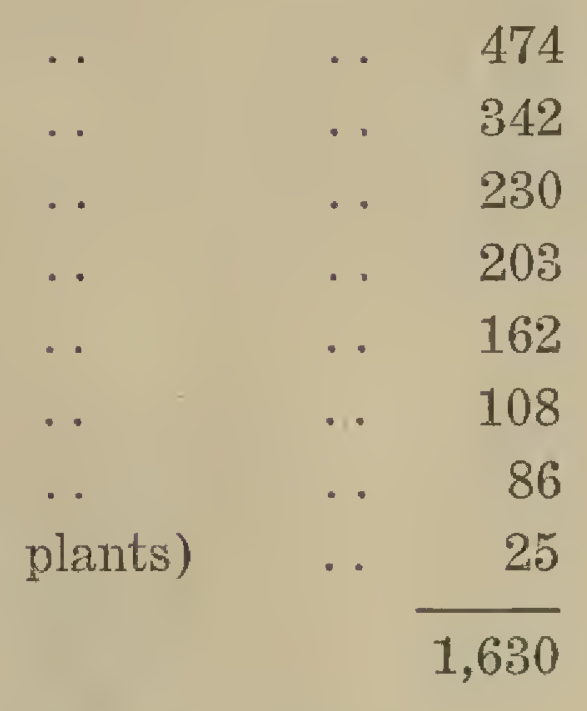
Dr. E. D. MERRILL, New York Bureau of Science, Manila ... Forest Research Institute, Kepong Arnold Arboretum, U.S.A. Botanical Survey, Pretoria, S. Africa Imperial Forestry Institute, Oxford Prof. W. G. CRAIB, Aberdeen (Siamese plants)

The following sheets were mounted and laid during the year:$\begin{array}{llll}\text { Local collections } & \ldots & \ldots & 1,281 \\ \text { Specimens acquired in exchange } & \ldots & \ldots & 1,769\end{array}$

Mr. C. X. FuRTADo, Assistant Botanist, worked in the Herbarium at the Botanic Gardens, Berlin, from June 6th 1933 to January 14th 1934, with the exception of a fortnight's holiday, during which he visited botanical institutions in Italy, Austria and Czechoslovakia, particularly the herbarium of the Natural History Museum, Vienna, Webb's Plant Museum at the University, Florence, and Beccari's palm herbarium, in the possession of Professor CoUNT MARTELLI (since deceased) at Soffiano near Florence. On January 16th Mr. FurTado reached London, and spent the following two months and a half working in the herbalia at Kew and the British Museum (Natural History). On his return to Singapore, he broke his journey for a short visit to the herbarium of the Natural History Museum at Paris. At all the herbaria above mentioned, Mr. FURTADo studied types and other important specimens of Malayan plants not available in Singapore, particularly of Palms and Aroids. Grateful thanks are expressed to those in charge of the herbaria for facilities granted to Mr. FURTADO, and for personal assistance given; special thanks are due to Professor Dr. M. BuRRET of Berlin, who placed his great experience in the study of palms at Mr. FURTADo's disposal. As a result of these studies, Mr. FurTado has gained much new knowledge concerning Malayan palms and aroids, and two papers had already been published by the end of the year, while others were in preparation. During the latter part of the year Mr. FURTADO was working on the rattans, an exceedingly difficult group, the local species of which are still very incompletely understood.

After his return to Singapore, Mr. FURTADo continued as usual his charge of the herbarium of cultivated plants, and his work of indexing references to plants of local interest in current literature.

Cryptogamic Herbarium. Mr. CORNER continued his investigations on Basidiomycetes, particularly the Polyporaceae. With the aid of material obtained from Kew, he is undertaking the revision of the yellow-brown polypores. Fungus specimens were received for identification from the Department of Agriculture and the Rubber Research Institute.

A new Fungarium was constructed of permanent materials in the potting yard for Mr. CORNER to continue his studies of the development and growth-rate of the higher fungi. The building, which measures about 20 feet long by 6 feet wide and 8 feet high, consists of a brick wall, 3 feet high, on a sloping concrete base, and in the upper part of a metal framework (constructed by the Singapore Trade School) covered above and on the sides with wire gauze. Snails and beetles are thus excluded, and the logs of wood are kept damp by means of a rotating sprinkler. Such a building provides the only satisfactory means of studying the growth of wood-destroying fungi, and we believe that comparable investigations have never before been made in the tropics. 
About 150 duplicate specimens of fungi were received from $\mathrm{Mr}$. C. J. HUMPHERY. The sheets and specimens of Ganoderma, lent for study by Mr. HUMPHERY on 1930, were returned from the Bureau of Science, Manila.

The Director continued his work on Malayan ferns, and took the opportunity of visits to Leiden and Copenhagen for the examination of type specimens. Thanks are due to Prof. Dr. H. J. LAM of Leiden and to Dr. CARL CHRISTENSEN of Copenhagen, for facilities given for the study of specimens, and for personal assistance. At Kew and the British Museum types and other specimens of interest were also examined, particularly of Malayan tree-ferns and the genus Lomagramma. The identification of a collection of ferns made by the Oxford University Expedition to Sarawak in 1932 was also completed; a set of specimens of this collection was retained for the Singapore herbarium.

\section{PUBLICATIONS}

The Gardens Bulletin.-Vol. VII part 3 and Vol. VIII part 1 were published on June 1st and October 10th respectively. Their contents were:-

VOL. VII PART 3.-

The ferns of Mount Kinabalu, by CARL CHRISTENSEN and R. E. HoLTTum. This is a complete enumeration of all ferns (417 species) hitherto collected on Kinabalu, with a description of 30 new species. There are also critical notes on a number of other species, about 80 of which are recorded for the first time from Borneo, and an introductory section of field notes.

VOL. VIII PART 1.-This contains three papers.-

Notes of Malayan Dipterocarpaceae II, by C. F. SYMINGTON (Forest Research Institute). This consists of critical notes on the nomenclature of important timber trees.

The genus Selaginella in the Malay Peninsula, by A. H. G. Alston (British Museum). This contains a key, enumeration of species and critical notes on this difficult genus, of which Mr. ALSTON has made a special study.

Notes on the biology of Macaranga spp., by J. A. BAKER (Department of Agriculture). This short paper contains some original observations on the relations of ants with the trees in question.

In addition, the following papers were published elsewhere by members of the Gardens staff: -

The Sources of "Tuba" in the Malay Peninsula (Malayan Agricultural Journal, March 1934). This illustrated paper is the result of field and herbarium study of all locally cultivated varieties of Tuba.

The limits of the genus Areca Linn. and its sections, by C. X. FurTado (Fedde, Repertorium, Berlin, XXXIII pp. 217-239).

Palmae Malesicae I by C. X. FurTado (Fedde, Répertorium, XXXV, pp. 273-283). These two papers represent the first results of Mr. FuRTADo's work on Malayan palms above mentioned.

The Director prepared a Guide to the Waterfall Garden, Penang, which was printed and issued during the year.

The Director continued to edit the horticultural section of the M.A.H.A. Magazine, and articles were contributed to it by himself, Nr. FLIPPANCE, Mr. HENDERSON and Mr. BEST. The Director's articles were mostly concerned with new or interesting plants and ornamental trees; Mr. FLIPPANCE's articles consisted of a series on garden planning in Malaya, a neglected subject to which he has devoted a good deal of attention.

The Director and Mr. FLIPPANCE contributed chapters to the Y.W.C.A. publication Gardening for Amateurs in Malaya.

The Director also contributed two articles to the 1934 issue of the Malayan Orchid Review. 
PLANTS OJTWARDS AND INWARDS

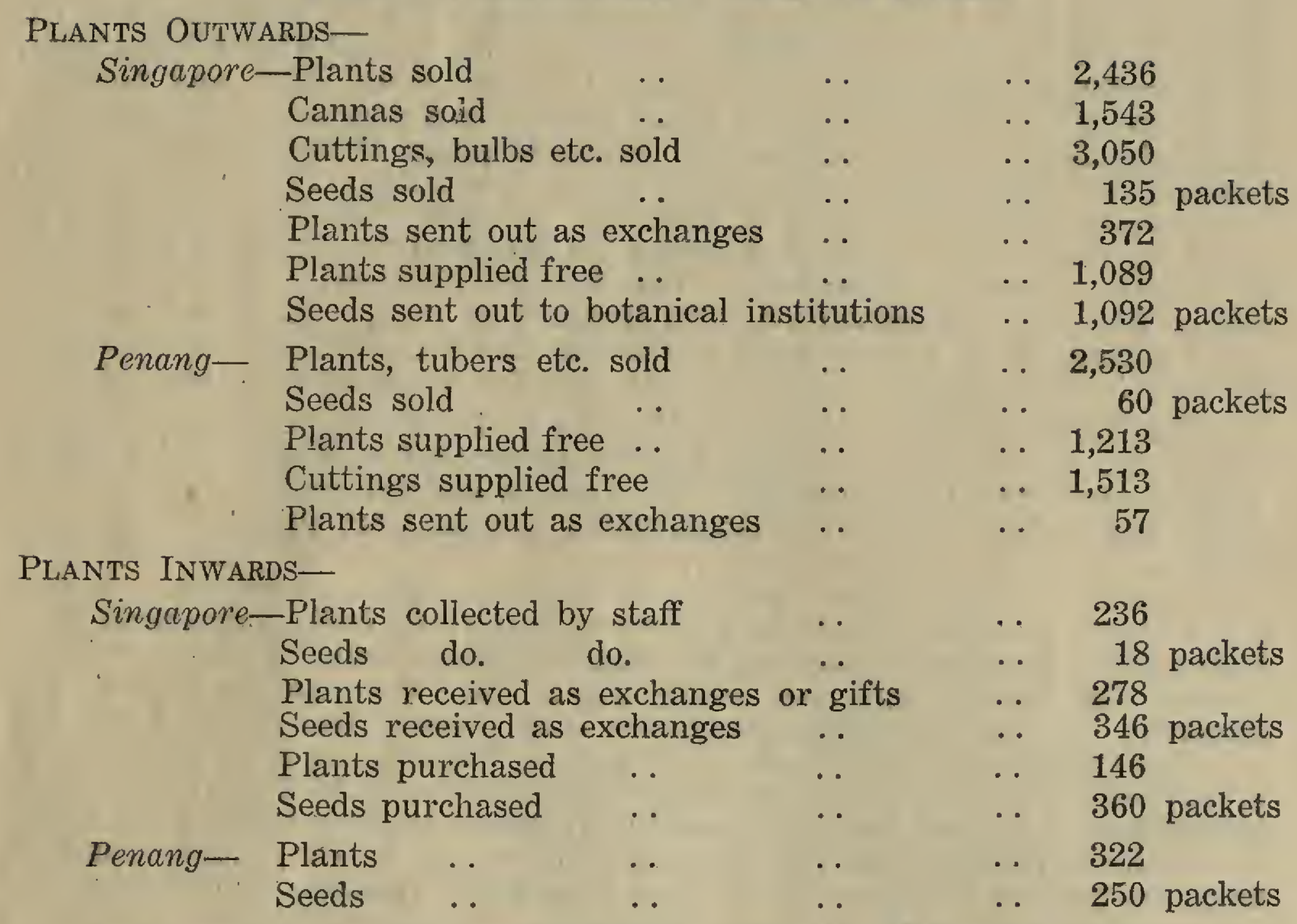

Gifts are gratefully acknowledged from the following persons and institutions: Phya Pradibadda Bhubal; Mr. E. D. Butler; Dr. L. Croizat; Capt. AmbRose Dunstan ; Forest Research Institute, Kepong; Major F. HAYES; Capt. H. Johnstone (Palm seeds from Para); Mr. J. J. van DER LAaN, Medan (200 seedlings of Pinus Merkusii for Penang Hill) ; Mrs. W. I. L. LEGG; Mr. LOH BoK ChOON; Mr. G. R. Mills; Dr. W. T. QuAIFe; Miss C. REID; Serdang Experimental Plantation; Mr. W. N. C. STEele; Mr. C. TAKahashi; Mr. Z. TERUYA; Dr. E. D. B. WOLFE. Exchanges of plants were effected with a number of persons and institutions; among these thanks are due particularly to the Director of the Royal Botanic Gardens, Kew, Sir JEREMIAH CoLMaN BART., and Mr. K. TOMARI, Imparial University of Kyoto. Seeds were received as exchanges at Singapore from 25 institutions and persons, and sent out to 53 botanical institutions.

\section{THE BOTANIC GARDENS, SINGAPORE}

The Plant Houses.-Numerous additions were made to the series of local orchids in the small plant house; this series is now fairly representative of all genera and subgenera which can be kept under conditions of cultivation in Singapore. Additions were also made to the collection of other epiphytes. The nibong slats on the roof of the small plant house were renewed by the Gardens staff, and repairs were effected by the Public Works Department to the framework of the large plant house. There was no change in the general arrangement of the houses. The descriptive labels were maintained.

The Lake.-The lake was drained and cleaned very thoroughly in August, a considerable amount of mud being removed from the upper end. The subsequent growth of Nymphaea seedlings was very large, but they suffered badly from attack by larvæ of a water beetle which ate the young leaves. Some fine new Nymphaeas, raised from seeds kindly sent in 1933 by H.R.H. PRINCE CHATRA MONGOL, Bangkok, were planted out and flowered well. A collection of all available species and varieties of Ixora was planted on the western bank towards the foot of the lake; it is intended to add to this collection as opportunity offers.

Notes on plants of interest.-In April, the tall Corypha gebanga (Malaysian Talipot palm) near the office flowered, and during the rest of the year the fruits developed slowly. The plant was about 42 years old. Sixteen plants of Ficus carica, the edible fig, of four varieties, were introduced from England for trial. They grew well in large pots, and began to fruit, but in a few months they were attacked so severely by boring weevils and a species of longicorn beetle, the larvæ of which ate into the tap root, that most of the 
plants died. A possible solution of the problem of root attack is to graft the edible figs on to local wild species; this has been tried without success. A variety of Tecoma stans, introduced in 1933 from the United States Department of Agriculture, was planted out beside the lower Ring Road, and flowered exceptionally well towards the end of the year; it is a finer form of the species than that hitherto in local cultivation. A row of plants of the Cannon-ball tree (Couroupita guyanensis), the seeds of which were obtained from Peradeniya, were planted along the border of lawn $\mathrm{R}$. The only mature tree at present in the Gardens is in a position in which its beautiful flowers are not seen by the public. Bauhinia yunnanensis has flowered frequently during the last year or two. It was introduced from Bangkok in 1929. The flowers are not very striking, but it is interesting as the only small-leaved Bauhinia which has flowered in the Gardens. There are at least two others which never flower.

The Bandstand Hill.-Towards the end of the year, the large Oleander bed on the terrace above the plant-house entrance was closed, and a series of smaller beds made to accomodate all the species and varieties of Zephyranthes and Cooperanthes. The three Cooperanthes hybrids were raised by Mr. J. N. MILSUM at Kuala Lumpur, and presented by him a few years ago. Of Zephyranthes, there are at present five species and one hybrid. A new introduction, Daedalacanthus purpurascens (native of India, introduced from Dehra Dun) promises to be a useful small bedding shrub. It has violet-blue flowers, fading with age, and young plants have flowered freely and continuously. A white Lantana, introduced from Penang, has flowered well but is badly attacked by scale insects. Plants of Vitex agnus-castus, planted in 1933, grew quite well, but flowered very poorly. The small flowers were quite inconspicuous, so that this shrub, which is said to be very beautiful in cooler and drier climates, is not likely to be of much use in Singapore, though it might be tried at Malayan hill stations. Bauhinia Galpinii, which has a deep orange-red flower, grew strongly during the year, and flowered a little in the dry weather in December. It is a south African species, in habit a scandent shrub; the indications are that it will not flower very freely in Singapore.

New Planting.-Additions were made to the collection of Hibiscus varieties by the Main Gate Road, a plant of Lonchocarpus cyanescens, which was too spreading, being removed to accomodate some of them; the Lonchocarpus was removed to lawn $\mathrm{H}$. About 50 varieties of Hibiscus are now planted out. New plants of Arenga saccharifera (Kabong) were planted to replace the avenue leading down to Tyersall Gate. The following recently introduced plants were planted; the names in brackets indicate the origin of the seeds.-

TREES-Antiaris africana (Gold Coast), Albizzia fierruginea (Gold Coast), Bumelia buxifolia (Honolulu), Ceiba pentandra (Gold Coast), Cratoxylon Maingayi (Penang), Cassia grandis, Casuarina, various (additions to former planting), Couroupita guyanensis (Peradeniya) Erythrina sp. (Washington), Erythrina speciosa (Cuba), Ficus bengalensis, Khaya grandiflora (African mahogany, from the Gold Coast), Licania arborea (Mexico), Lecythis sp. (Panama), Pometia alnifolia, Pentaclethra filamentosa (from Raffles College), Ricinodendron africanum (Gold Coast), Sarcocephalus cordatus (Burma), Swietenia humilis (Mexico), Sterculia Kunstleri (?), Tectona Hamiltoniana (Denra Dun).

PALMS.-Aceoloraphe Mayana (British Honduras), A. arborescens (British Guiana), Adonidia Merrillii (Philippines), Attalea spectablis (from Capt. JoHNSTONE), Chamaerops humilis (Portugal), Cocos flexuosa (Cuba), Copernicia cerifera (Brazil), Corypha taliera (Calcutta), Livistona australis (Calcutta), Livistona decipiens (from Capt. H. JoHNSTONE), Pritchardia pacifica (Florida), Sabal Blackburnianum (Bermuda), Scheelia Urbaniana (from Capt. H. JoHNSTONE).

SHRUBS.-Acacia glomerosa (British Honduras), Acacia Hindsii (Br. Honduras), Acacia podaluriifolia (from Dr. QUAIFE), Daedalacanthus purpurascens (Dehra Dun), Crescentia alata (Mexico), Saraca triandra, Unona laevigata (Bombay).

Losses.-In September, during a violent storm, the very large liane of Entada spiralis hanging between two trees near the Director's house, was broken, falling in several pieces. During the same storm a tree of the local oak Pasania conocarpa in the jungle beside Maranta Avenue, was struck by lightning and killed. The same flash also killed branches of neighbouring trees, and shrubs on the ground. This leaves a gap in the small area of jungle to the south of Maranta Avenue. A fine tree of Palaquim sp. fell down in another 
part of the jungle. Two very old tall palms of Rhopaloblaste hexandra on the border of lawn $\mathrm{R}$ had to be removed as unsafe. Two more of the old Oil Palms in the Gardens died and were removed. Our only plant of Lafoensia punicifolia, a rather pretty and unusual shrub of the family Lythraceae, from tropical America, died. It never produced seeds, and the species is now lacking in the Gardens. Two young trees of Jacaranda acutifolia, planted at the end of 1932, died during the year. They made very weak growth, and it appears that the species is unsuited to Singapore. The old plant of Macrozamia Peroffskyana on the Bandstand Hill, died during the year. The tree-ferns from Honolulu mentioned in the report for 1933 also died.

Orchids.-Some additions were made to the orchid collection by purchase and exchange. Cultivation of hybrids continued, the only new flowering during the year being a plant of Phalaenopsis violacea $\times$ grandiflora, which appears to be quite distinctive. Mr. LOH BOK CHOON of the College of Medicine, kindly presented a fine white variety of Spathoglottis plicata, not hitherto represented in our collections, and this has been crossed with $S$. aurea. At the Singapore and Johore Flower Show, held at the New World early in April, some fine plants of Dendrobium Farmeri wexe the chief feature of the Gardens exhibit.

\section{THE WATERFALL GARDEN, PENANG}

The Garden was maintained in good order, and the usual routine work carried out. Minor alterations were made by closing the path across lawn $\mathrm{E}$, closing the flower border beside the stream in section $\mathrm{S}$ and improvements to the formal garden in section $V$. The path on lawn $E$ was troublesome to maintain, and its filling has improved the appearance of the area. The flower border in section $S$ was never very satisfactory, partly owing to the roots of the neighbouring large Waringin, and partly to periodical flooding by the stream. In the formal garden conifer's in concrete pots were added, and the ornamental entrance gate erected.

Plant-house No. 10 has now become the fern house, and as such is a success. The collection of maidenhairs has been considerably improved, and a collection of foliage Begonias developed. In the house are also exhibited orchids in flower and other plants of special interest.

New Planting.-Considerable additions were made to the palm collection in section $\mathrm{C}$, the unused portions of the area being almost completely filled. The species planted-were: Phoenix humilis, Licuala sp., Pritchardia sp., Ptychosperma Sanderiana, Cyrtostachys lakka, Gulielma utilis, Kentia Woodfordii, Verschaffeltia splendida, Thrinax sp., Martinezia erosa, Livistona rotundifolia, Sabal palmetto, Phoenix sp., Rhopaloblaste hexandra, Hyophorbe Verschaffeltii, Heterospathe elata, Didymosperma porphyrocarpon, Didymosperma sp., Actinorhytis calapparia, Cocos sp., Pinanga sp., Archontophoenix alexandrae, Eugeissona tristis. In section D the single varieties of Hibiscus were grouped in threes, 32 plants of 16 varieties being added. In section $\mathrm{E}$ plants of the following Casuarinas were added: C. sumatrana, C. Rumphiana, $C$. montana, $C$. quadrivalvis. In section $\mathrm{E}$ a bed was planted with five seedlings of Bougainvillea lateritia. In section F a considerable number of conifers were planted, and began to to make good growth. These included species of the genera Cupressus, Juniperus, Podocarpus, Araucaria, Cryptomeria and Thuja. In section $M$ the following species were added to the collection of Ficus spp.: $F$. viridicarpa, $F$. involuta, $F$. Miquelii, $F$. glomerata, $F$. hirta. One hundred plants of Vanda Hookeriana were added to the Orchid and Succulent garden in section $K$. The following climbers were added to plant-house No. 1: Afgekia sericea, Porana volubilis, Jasminum kedahense, Clematis triloba.

Buildings. - The roofs of plant-houses Nos. 1, 8, and 9 were stripped and re-roofed with meranti laths (treated with Solignum) instead of Bertam. The result is a much neater appearance, and it is hoped also a more permanent roof. The potting shed was rebuilt by the Public Works Department. The new structure, of permanent materials, is much larger than the old, and is a great improvement. It was completed by the following additions made by the Gardens staff: concrete floor and surrounding drain, potting benches, soil bin and water tank. Plant-house No. 6 (in the potting yard) was also rebuilt by the Public Works Department, with concrete posts, steel roof framework and hard-wood laths. The house was completely enclosed with wire netting by the Garden staff, as a protection against monkeys. A new water tank was made for the pot-plant nursery, a small lean-to shed built at the workshop to accomodate the small mowing machines, and repairs were effected to the foundations of the upper bridge, also to the stonework at the base of the aqueduct and footbridge below the fern rockery. 
Losses.-Seven trees and one palm, of species common in the Garden, were removed for improvement purposes. The large trees of Erythrina indica and Ficus benjamina in the potting yard were pruned heavily to let more light and air into the yard. Several trees above the road near the entrance path to the lily pond gully were unsafe and had to be removed.

\section{GOVERNMENT HOUSE DOMAIN AND OTHER
OUTSIDE CHARGES}

\section{SINGAPORE}

Government House Domain was maintained as usual. Towards the close of the year, a re-arrangement of the beds on the terraces in front of Government House was begun, at the request of H.E. The Governor. Thirty-four flowering trees and forty-seven shrubs were planted in various parts of the Domain.

The supervision of tree-planting in the catchment area around the reservoirs was continued by Mr. CoRNer, whose report is as follows.

MacRitchie Reservoir.-A few trees which had died on the edge of the Reservoir were replaced.

The remaining trees, planted in former years, are growing unevenly. Some have done well, others poorly. It is difficult to find good flowering trees which are able to compete with the jungle trees round the edge of the Reservoir or to grow in the hard, poor soil along the foot of Bukit Timah Golf Course. The most satisfactory tree appears to be Adinobotrys atropurpurea.

The small flowering trees, Saraca and Cassia multijuga, planted near the Lake House and by the Water House at the head of the Reservoir, have grown well, particularly the Saraca. A large number of seedlings of Saraca are being raised in the Botanic Gardens to continue planting at the edge of the jungle. Saraca is one of the showiest of small flowering trees.

Pierce Reservoir. - Many of the trees planted on the hillsides at the $81 / 2$ mile Thomson Road were killed by mousedeer, which ate the bark, and by monkeys which brolke the saplings. Most of these were replaced by the hardier kinds raised in the small nursery established at the Coolie Lines. A further area of hillside was planted up with the hardier trees raised in the nursery, and an additional 300 trees were sent up from the Botanic Gardens.

The experiment of planting the hillsides with fast-growing trees has been sufficiently successful to be continued. About half the trees have survived and the majority of these are over six feet high. But it is only by experience that one can find suitable trees. A large variety of seedlings are being raised in the Botanic Gardens for this purpose.

Inspection of roadside tree planting was carried out as usual for the Municipal Commissioners. Advice with regard to tree planting was given at H.M. Naval Base and R.A.F. Base.

\section{PENANG}

Hill Gardens.-At the entrance to Bel Retiro an avenue of Cypresses was planted all along the path, and the slope down to Summit Road was also planted with similar trees; in all 49 trees were planted. About 30 Australian trees, chiefly Eucalyptus, were planted on the slopes towards Convalescent bungalow. The flower border below the tennis court was replanted with blue and mauve flowers. Strawberxy Hill was maintained as usual, and a few Cypress and Spathodea trees planted; the lower terrace on the west side was grassed. At the Crag Hotel 79 Cypress trees were planted, chiefly in the hollows of the lower slopes; these should provide an excellent background and foundation for the terrace planting, which is developing satisfactorily. The caves below the large boulders, through which the lower path passes, were planted with maidenhair ferns and Cypripediums. A number of alterations and improvements were made in the planting of shrubs at Convalescent bungalow, and the slopes on the west side of the path down to Bel Retiro gate were cleared, re-cut, and re-grassed. The slopes between Convalescent and Fernhill were cleared and prepared for planting Pinus Merkusii, the Sumatran Pine, of which a large number of seedlings were presented through the kind offices of Mr. J. J. VAN DER LAAN, of the Deli-Courant, Medan. It is hoped that in some years time the slopes in question will be covered with an attractive pine wood. The gardens at the other hill bungalows were maintained as usual. 
Municipal inspections.-The usual inspections of Gardens and Roadside trees were made, and reports prepared where necessary. A proposed park area off Western Road was inspected by the Assistant Curator in company with the Municipal Engineer. Advice was given and a plan outlined for the re-afforestation of the Municipal area on the lower slopes of "Highland" hill; various seeds have been provided to assisi in this work.

Other Work.-Advice was given regarding garden planning and planting in the following grounds: The Residency; the Hindu Temple, Waterfall Road; the New English School, Westlands; Government Offices; Trade School; St. George's Church compound; the Y.W.C.A. tennis court; Penang Golf Club; Penang Turf Club, Penang Flying Club. Plans were made of the Residency garden, and of a scheme for a new lay-out of grounds adjacent to the new Staff Quarters at the General Hospital.

R. E. HOLTTUM, Director of Gardens,

Straits Settlements. 





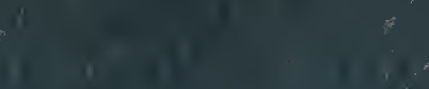

列

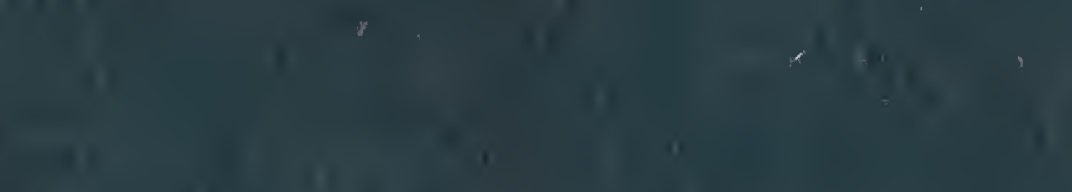
(1)

$\because$

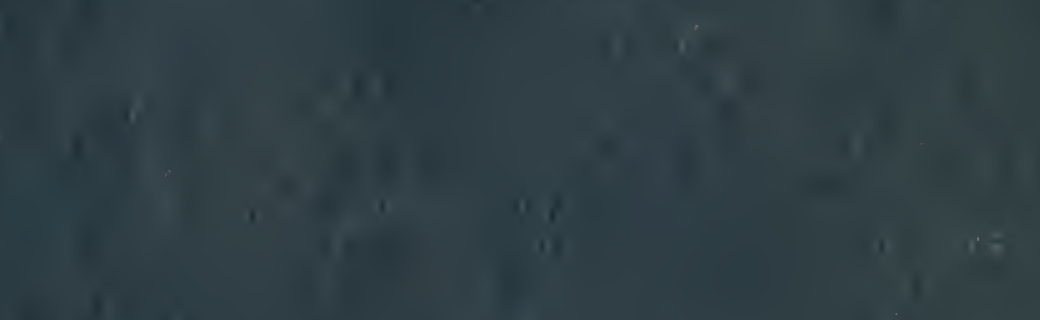

in is

$\sqrt{12}$

$\operatorname{lin}+6 y$

'in'

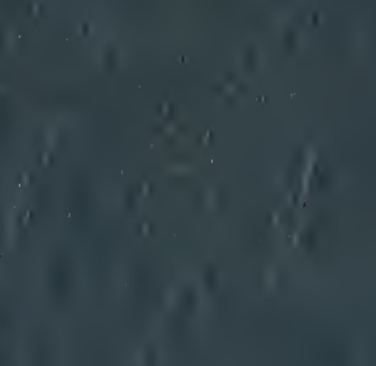

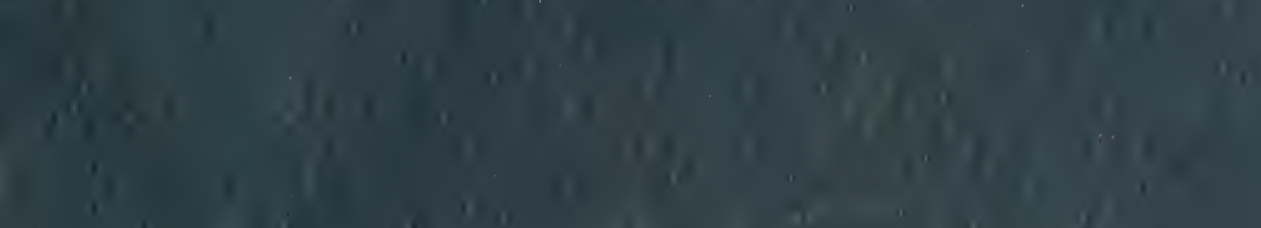

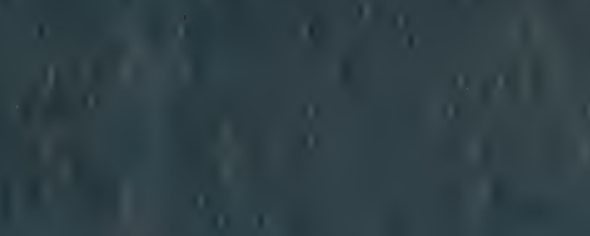

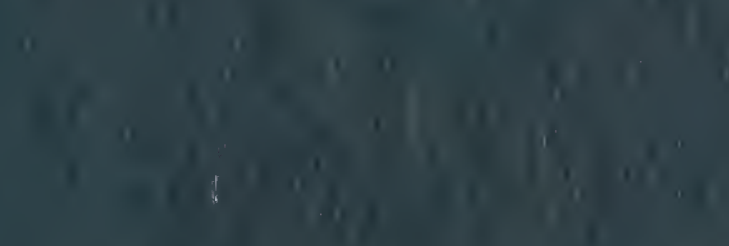

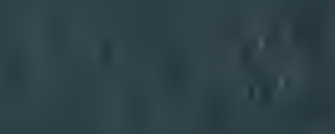

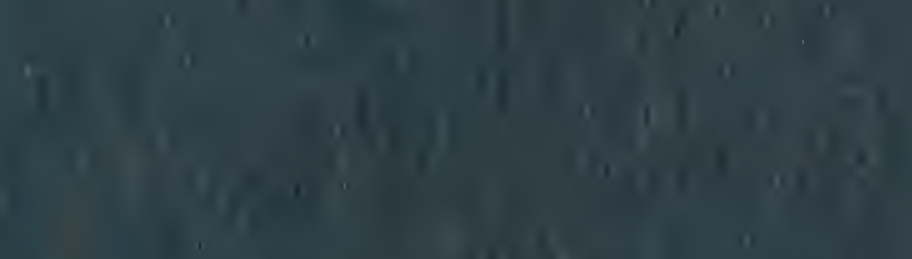
$(119$

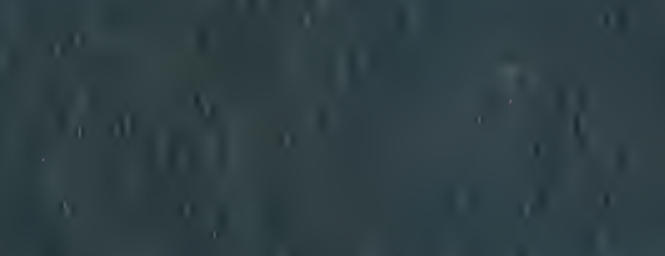

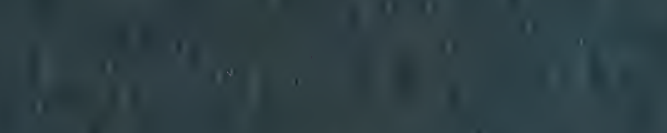

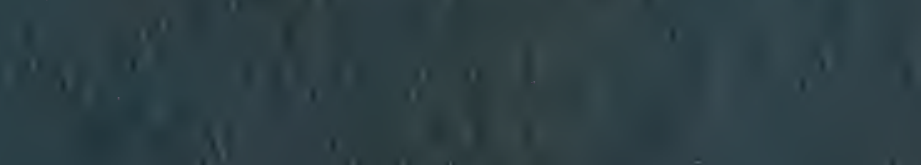


